\title{
HLA-DP and HLA-E : targets for transplantation immunity
}

Citation for published version (APA):

Lauterbach, N. (2014). HLA-DP and HLA-E : targets for transplantation immunity. [Doctoral Thesis, Maastricht University]. Maastricht. https://doi.org/10.26481/dis.20140117nl

Document status and date:

Published: 01/01/2014

DOI:

$10.26481 /$ dis.20140117nl

Document Version:

Publisher's PDF, also known as Version of record

\section{Please check the document version of this publication:}

- A submitted manuscript is the version of the article upon submission and before peer-review. There can be important differences between the submitted version and the official published version of record.

People interested in the research are advised to contact the author for the final version of the publication, or visit the DOI to the publisher's website.

- The final author version and the galley proof are versions of the publication after peer review.

- The final published version features the final layout of the paper including the volume, issue and page numbers.

Link to publication

\footnotetext{
General rights rights.

- You may freely distribute the URL identifying the publication in the public portal. please follow below link for the End User Agreement:

www.umlib.nl/taverne-license

Take down policy

If you believe that this document breaches copyright please contact us at:

repository@maastrichtuniversity.nl

providing details and we will investigate your claim.
}

Copyright and moral rights for the publications made accessible in the public portal are retained by the authors and/or other copyright owners and it is a condition of accessing publications that users recognise and abide by the legal requirements associated with these

- Users may download and print one copy of any publication from the public portal for the purpose of private study or research.

- You may not further distribute the material or use it for any profit-making activity or commercial gain

If the publication is distributed under the terms of Article $25 \mathrm{fa}$ of the Dutch Copyright Act, indicated by the "Taverne" license above, 


\section{HLA-DP and HLA-E:}

Targets for Transplantation Immunity 
(C) Nina Lauterbach, Maastricht 2014

Layout: Tiny Wouters

Production: Datawyse | Universitaire Pers Maastricht

ISBN: 9789461592934

The printing of this thesis was financially supported by Sanbio, BD Biosciences and Beckman Coulter 


\section{HLA-DP and HLA-E:}

Targets for Transplantation Immunity

\section{PROEFSCHRIFT}

ter verkrijging van de graad van doctor aan de Universiteit Maastricht, op gezag van de Rector Magnificus, Prof. Dr. L.L.G. Soete volgens het besluit van het College van Decanen, in het openbaar te verdedigen op vrijdag 17 januari 2014 om 10.00 uur door

\section{Nina Lauterbach}

geboren op 12 januari 1985 te Heerlen

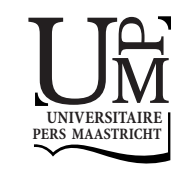




\section{Promotor}

Prof. Dr. M.G.J. Tilanus

\section{Co-promotores}

Dr. C.E.M. Voorter

Dr. L. Wieten

\section{Beoordelingscommissie}

Prof. dr. J.P.M. Geraedts (voorzitter)

Prof. dr. M.P. van Dieijen-Visser

Prof. dr. I. Joosten, UMC St. Radboud Nijmegen

Prof. dr. M.A.G.G. Vooijs 


\section{Contents}

Chapter 1 Introduction 7

Chapter 2 Full length HLA-DPB1 diversity in multiple alleles of individuals from Caucasian, Black or Oriental origin

Chapter 3 Effects of transmembrane region variability on cell surface expression and allorecognition of HLA-DP3

Chapter 4 Allorecognition of HLA-DP by CD4+ T cells is affected by polymorphism in its alpha chain

Chapter 5 Molecular typing of HLA-E

Chapter 6 The induction of HLA-E translation upon extracellular peptides in human PBMCs is dependent on peptide sequence and HLA-E genotype

Chapter 7 HLA-E regulates the NKG2C+ NK cell function through presentation of a restricted peptide repertoire

Chapter 8 HLA-E polymorphism is associated with risk of infection and severe acute GVHD in unrelated hematopoietic stem cell transplantation

Chapter 9 General discussion 155

Summary 175

Samenvatting 181

Dankwoord

Curriculum vitae 



\section{Chapter 1}

Introduction 
8 Chapter 1 


\section{Introduction}

\section{Discovery of the major histocompatibility complex}

In the 1900's scientists were already focusing on the mechanisms behind the growth of cancerous cells. Researchers transplanted a tumor from a mouse in a healthy host and observed that in some cases the tumor would grow in the new host, but in other cases the tumor-growth would be absent and the tumor would eventually disappear. What caused a tumor to grow or disappear was unclear, nevertheless researchers concluded that the animals they used as host made a great difference. In the 1930's Peter Gorer and George Snell discovered that skin grafts between mice with identical Antigen II alleles were accepted, while mice with different Antigen II alleles rejected the skin transplant $^{1,2}$. Gorer showed that the tumor resistance factor antigen II was not only expressed on malignant cells but also on all normal cells. He developed a theory regarding transplantation saying that animals of the same species but different inbred strains differed in these antigens and when tissues were exchanged between such animals, the antigens elicited an immune response that resulted in the destruction (rejection) of the transplant. Snell and Gorer showed that the resistance factors in some mouse models were most probably an allele at the locus coding for the antigen II. Snell proposed to call these tumor-resistance factors histocompatibility $(\mathrm{H})$ genes, including serial numbers to distinguish between the individual genes. $\mathrm{H}-2$ was the first identified histocompatibility gene and referred to antigen II. Snell discovered that some $\mathrm{H}$ genes resulted in a major (strong) effect in graft rejection and other in a minor (weak) effect. Researchers revealed in mice one region on chromosome 17 where all the major genes were located, the region where the original $\mathrm{H}-2$ gene was placed. Later on when a similar region in other species was discovered scientists referred to it as the major histocompatibility complex (MHC). The $\mathrm{H}-2$ complex acted as the MHC complex in mice, whereas $\mathrm{MHC}$ in other species received other names ${ }^{3}$.

In addition to the skin graft or tumor models, in-vitro assays (such as the mixed lymphocyte reaction, MLR) were developed and revealed the great complexity of the chromosomal region containing the $\mathrm{H}-2$ genes. It became apparent that each strain has a characteristic constellation of these genes. Only after discovering the MHC complex in mice and domestic fowl, the MHC complex in humans was identified. Jean Dausset, Rose Payne and Jon van Rood were the leading scientists that unraveled the MHC complex in human which they called the Human Leucocyte Antigen (HLA) complex. Dausset observed massive clumps, when mixing serum of a leukopenia patient with leukocytes from another subject, which indicated that leukocytes (just like erythrocytes due to a different blood group) could be agglutinated by antibodies. Payne, later on, noticed that leukoagglutinins were not only present in leukopenia patients but in all patients that were characterized by a history of multiple transfusions. Her study revealed that the leukoagglutinins had no connection to leukopenia but were antibodies against allogeneic antigens on the transfused leukocytes. In addition, Jon 
van Rood discovered in 1958 that women who had pregnancies in the past developed antibodies directed against paternal antigens present on the fetus. All three scientists observed that an antibody response was not present with all donors, and started a long and complex procedure in defining the system of genes that is responsible for an allogeneic reaction. New techniques, like the cytotoxicity and complement-fixation assays, were introduced to detect antigens. Because of the variety of antisera, cells and methods used in the different laboratories, results were difficult to compare. Therefore in 1964 it was decided to organize International Histocompatibility Workshops were all laboratories could present and discuss their results. It was concluded that there is indeed one complex of genes, like the mouse genes, that encodes for the human leucocyte antigens, the so-called Human Leucocyte Antigen (HLA) system ${ }^{3}$.

The HLA system was divided in different sub-types (loci); HLA-A, -B and -C. After the extensive use of MLRs it became clear that correlation between serologically defined determinants and MLR determinants was not absolute. Multiple groups around 1965 discovered that MLR and immune responses were also controlled by genes within the $\mathrm{MHC}$ region that were different from the already known loci. The genes were first named the immune response 1 (Ir-1) genes. It was difficult to serologically detect the antigens encoded by these genes, however in 1973 van Leeuwen and colleagues could detect these antigens on a small percentage of leukocytes. It became clear that the antigens were expressed on the antigen presenting cell subsets, not on T cells. In 1977, Klein suggested to call these new molecules class II and the previously defined molecules HLA class $I^{3}$. Nowadays, the names are generally accepted and used. It is now known that the HLA system can be subdivided in HLA class I and class II genes located on the short arm of chromosome $6(6 \mathrm{p} 21.3)^{4}$ and that it represents the most polymorphic genes of the human genome. Since 1985, molecular techniques evolved and have been introduced to identify DNA polymorphism and the correlation with known cellular and serological specificities. Today almost 7000 HLA class I alleles and 2000 HLA class II alleles have been identified (IMGT/HLA 3.11.0). Due to this high polymorphism, matching between patient and donor is complex and patient outcome after hematopoietic stem cell transplantation (HSCT) can be variable.

\section{Organization and function of HLA class I genes}

HLA class I molecules, which are expressed on most nucleated cells, are heterodimeric membrane bound glycoproteins that consist of a polymorphic $43 \mathrm{kDa} \alpha$ or heavy chain in non-covalent association with a non-polymorphic $\beta 2$ microglobulin (12 kDa) protein which is coded for on chromosome 15 . The class I molecules can be classified into the classical HLA-A, -B and -C and the non-classical HLA-E, - F and -G. The class I molecule is anchored into the cell membrane solely by the $\alpha$-chain, which consists of three extra cellular domains ( $\alpha 1,2$ and 3 ), a transmembrane region and a cytoplasmic chain. The $\alpha 1$ and $\alpha 2$ domains fold together into a structure consisting of a floor of anti-parallel $\beta$ pleated sheets flanked by a pair of anti-parallel $\alpha$ helix side walls, thereby creating a 
groove to which peptides can bind. The HLA class I binding peptides bind to the groove through a series of hydrogen bonds and ionic interactions at each end of the peptide. The HLA class I genes encoding these surface molecules represent a specific structure in which each exon encodes a different domain of the molecule. Exon 1 encodes the leader peptide, exons 2 and 3 encodes the two domains representing the peptide binding groove. The alpha 3 extracellular domain is encoded by exon 4 . The transmembrane anchor is encoded by exon 5, while exon 6 and exon 7 both encode the cytoplasmic tail. The $3^{\prime}$ untranslated region is encoded by exon 8 . The HLA-A, -B and -C alleles are highly polymorphic, mostly due to nucleotide substitutions in exons 2 and 3 , whereas HLA-E, $-F$ and $-G$ exhibit limited polymorphism ${ }^{5}$. HLA class I molecules bind peptides typically 8-10 amino acids long which usually are derived from intracellular proteins, like viruses. HLA class I molecules assemble with $\beta 2$-microglobuline in the Endoplasmatic Reticulum (ER) and there cytosolically derived peptides, which are transported into the ER by Transporters associated with Antigen Processing (TAP), can bind to the peptide binding groove of the assembled HLA molecule (Figure 1.1). Binding of peptide to the HLA molecule is crucial for the folding and for the stability. Only then when the HLA molecule is complete by $\beta 2$-microglobuline assembly and peptide binding the HLA molecule can leave the ER and can be transported to the cell membrane. On the cell surface the HLA class I molecule will present the peptide to the CD8+ cytotoxic T lymphocyte ${ }^{6}$. In case of a non-self peptide the T cell will be stimulated to proliferate and kill the infected target cell ${ }^{7}$. In addition to being a ligand to CD8+ T cells, the classical HLA class I molecules function as a ligand to NK cells amongst others via interaction with the killer-cell immunoglobulin-like receptors (KIRs) ${ }^{8}$. Presence of these ligands inhibits the NK cell via the inhibitory KIRs, however when the HLA class I molecules are downregulated (e.g. by viruses reviewed by Lodoen et al. ${ }^{9}$ or tumors reviewed by Bukur et al. ${ }^{10}$ ) NK cells will eliminate the target cell ${ }^{11}$. HLA-E is generally known to present leader segments from the classical HLA class I molecules and HLA-G to the NKG2 receptors on NK cells, thereby also playing a role in modulating NK cell function during various malignant conditions ${ }^{12}$.

\section{Organization and function of HLA class II genes}

The HLA class II locus encompasses approximately $700 \mathrm{~kb}$ on chromosome 6 . The HLA class II genes can be classified into HLA-DR, -DQ and -DP. The HLA class II molecules are heterodimeric membrane bound glycoproteins consisting of two non-covalently associated polymorphic chains, $\alpha$ (34 kDa) which consists of an $\alpha 1$ and $\alpha 2$ domain and $\beta$ (29 kDa) that comprises a $\beta 1$ and $\beta 2$ domain. Both are anchored to the cell membrane. The $\alpha 2$ and $\beta 2$ domains are proximal to the cell membrane and have a folded structure that resembles that of an immunoglobulin $C$ domain. The $\alpha 1$ and $\beta 1$ domains are distal from the cell surface and fold together into a structure consisting of a floor of antiparallel $\beta$ pleated sheets flanked by a pair of anti-parallel $\alpha$ helix side walls. The folding 
of the $\alpha 1$ and $\beta 1$ domains creates a groove into which peptides bind. These peptides can be up to 30 amino acids long as the groove is open at both ends.

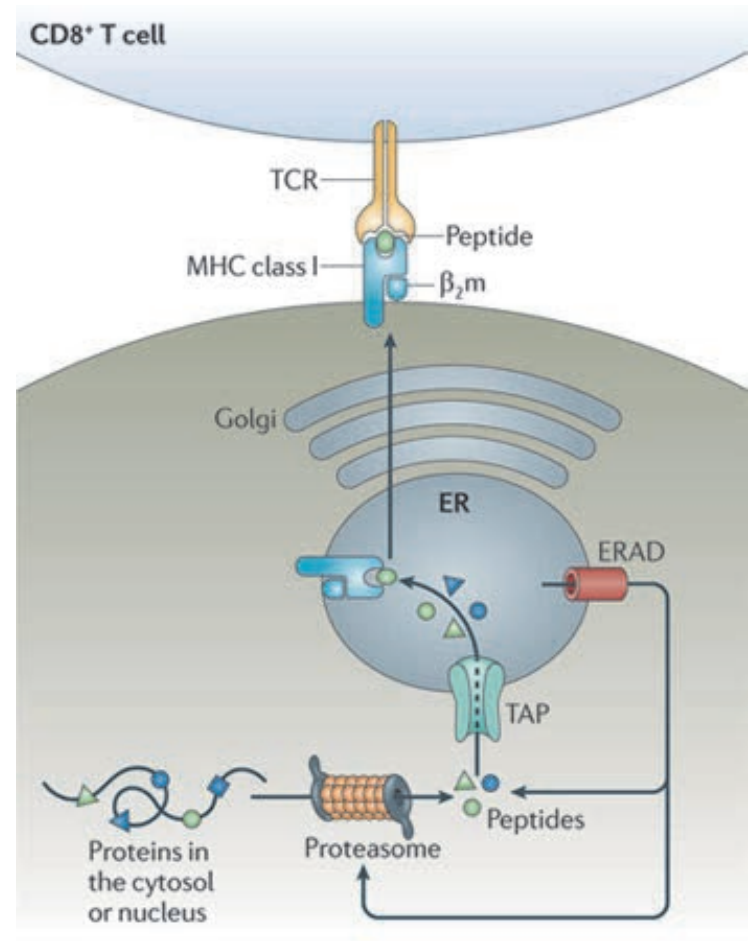

Figure 1.1 Schematic overview of the HLA class I antigen presentation pathway ${ }^{6}$.

The $\alpha$-chain and the $\beta$-chain are separately encoded by two different genes, which both consist of various exons that each encode different parts of the HLA class II surface molecule. Exon 1, in both the alpha and beta chain, encodes for the leader peptide and together exon 2 and 3 encode for the extracellular domains. The transmembrane domain in the beta chain is encoded by exon 4, and exon 5 encodes the cytoplasmic tail. By contrast, in the alpha chain both the transmembrane region and the cytoplasmic tail are encoded by exon 4. Most polymorphism is located on exon 2 of the beta-chain genes, while the alpha-chain genes are low polymorphic ${ }^{5}$. HLA class II molecules are expressed on all antigen presenting cells, that take up extracellular antigens in intracellular vesicles. As HLA class II molecules bind extracellular derived peptides the peptide presentation pathway of HLA class II differs from the pathway of HLA class I. HLA class II molecules are assembled within the ER, here the alpha and beta chain assemble with the invariant chain to stabilize the construct and prevent peptides 
from binding. This complex is then transported to the specialized vesicles called MHC class II compartment, where the invariant chain is degraded and replaced by a peptide. The HLA class II molecule including the peptide then moves to the cell surface where it interacts with the CD4+ helper T cell (Figure 1.2). In case of a foreign peptide derived from for example a bacteria or transplanted tissue, the CD4+ T cell can get activated to stimulate phagocytes to attack the extracellular bacteria or tissue and the CD4+ T cell can encourage B cells to produce antibodies ${ }^{6}$.

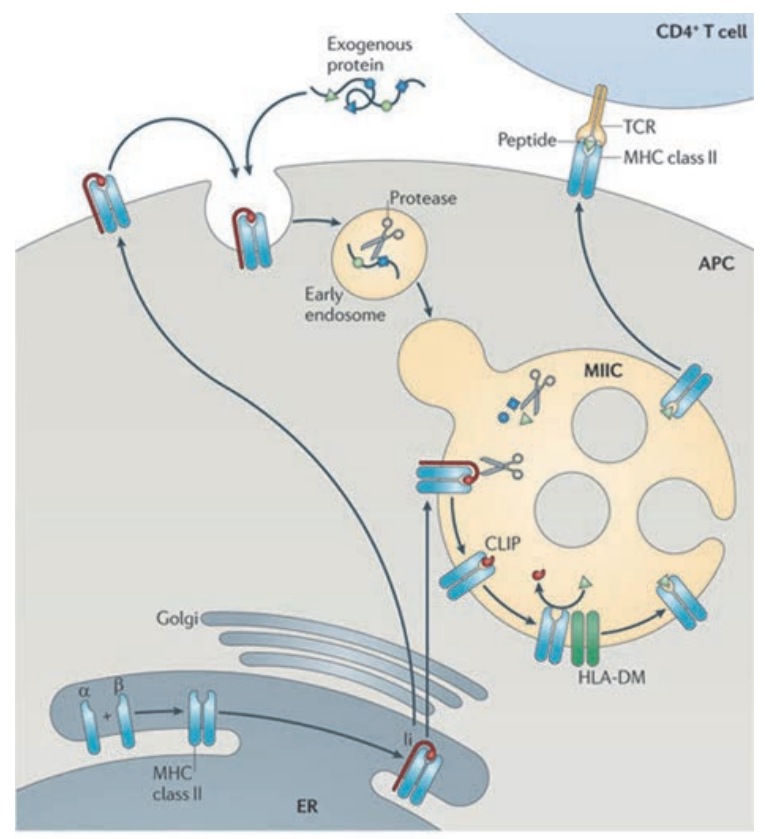

Figure 1.2 Schematic overview of the HLA class II antigen presentation pathway ${ }^{6}$.

\section{HLA nomenclature}

Because of the high polymorphism of the HLA genes, it was necessary to establish a systematic nomenclature which lied in the hands of an International committee sponsored by the World Health Organization (WHO). Historically, the system was based on serological names as the broad antigens were defined based on their reaction with antisera. Since the availability of nucleic acid-based information regarding the sequence of alleles a nomenclature complementary to the serological terms was established (Figure 1.3) ${ }^{13}$. 


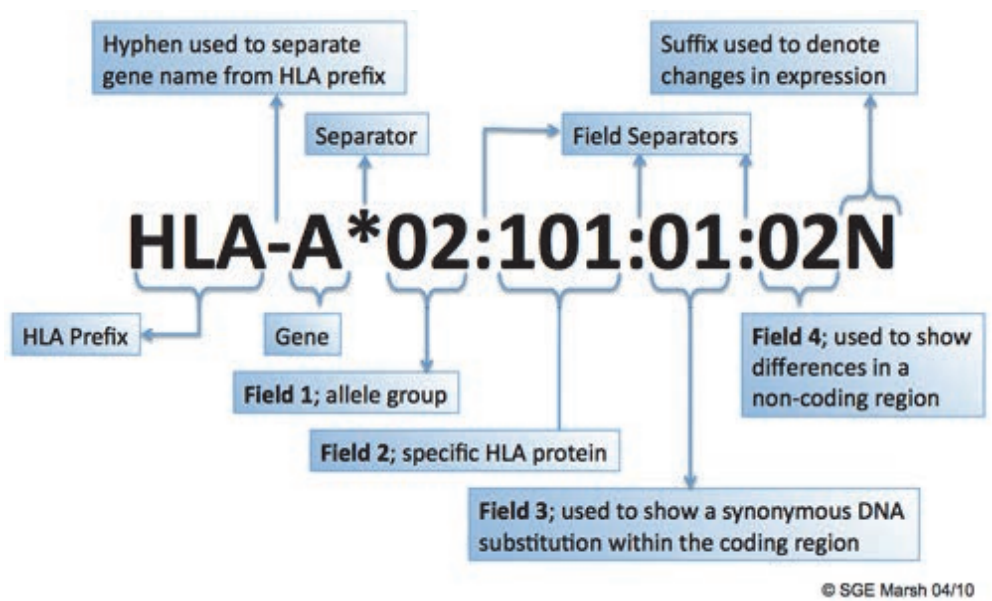

Figure 1.3 Description of HLA nomenclature established by the WHO (IMGT HLA database).

The first field of an allele name refers to the specific allele group and in HLA-A, -B, -C, DRB1 and -DQB1 this field is synonymous to the serological defined antigen. In Figure 1.3 as an example an HLA-A allele is shown, which is correlated to the HLA-A2 serological antigen. In contrast, for HLA-DP the numbering of this field is defined based on order of identification of the allele, as a link between the sequence and the serological antigen could not be defined. The second field refers to a specific HLA protein as alleles with differences in these digits encode for a distinct protein. This field is generally considered as being relevant in allorecognition, however studies focusing on the functional importance of the other fields are limited. The third field represent variations in coding regions that do not result in a protein difference, the so-called synonymous substitutions. The final field represent substitutions in the non-coding regions. In addition, a number of suffices were used to indicate the expression status of the protein encoded by the specific allele. Alleles shown not to be expressed are given the suffix ' $N$ '. Alleles resulting in a low cell surface expression are indicated with the suffix ' $L$ '. The variants that result in a protein that is exclusively secreted are given the suffix ' $S$ '. The suffix ' $C$ ' is used to indicate that the allele product is solely present in the cytoplasm. The suffix ' $Q$ ' is given when the expression of an allele is 'questionable' and alleles with aberrant expression are indicated with the suffix ' $A$ ' (http://hla.alleles.org/nomenclature/naming.html). As the expression level of HLA can influence the level of $\mathrm{T}$ cell alloreactivity these alleles could be of major importance regarding to patient outcome. Nevertheless, the expression-status of the alleles, except for the null-alleles, is not considered in matching procedures at this moment ${ }^{14}$. 


\section{HLA polymorphism and transplantation outcome}

T cells interact with the HLA/peptide complex expressed on the cell surface to distinguish self from non-self. In case of a foreign peptide or foreign HLA the T cell can initiate an immune response. It is this ability of $T$ cells to recognize non-self that necessitates HLA matching between patient and donor for stem cell transplantation. Hematopoietic stem cell transplantation (HSCT) is a well-established treatment in various hematologic malignancies. Following transplantation, $\mathrm{T}$ cells from the donor have the potential to recognize patient HLA as foreign which can lead to a vigorous immune response. In this case the donor lymphocytes will attack the host cells, therefore named as graft-versus-host disease $(\mathrm{GVHD})^{7}$. GVHD is a major cause of morbidity and mortality in HSCT. If GVHD occurs within 100 days post-transplantation it is referred to as acute GVHD, whereas development after 100 days is called chronic GVHD. The severity of acute GVHD is indicated by distinguishing four grades; grade I (mild), grade II (moderate), grade III (severe) and grade IV (very severe). Severe GVHD has poor prognosis, with $25 \%$ long-term survival ( 5 years) for grade III disease and $5 \%$ for grade IV. The occurrence of acute GVHD is directly related to the degree of mismatch between HLA molecules ${ }^{15}$.

To lower the risk of post-transplantation complications as much as possible, HLA matched family stem cell transplantation is preferred. Nevertheless, for only $30 \%$ of the patients an HLA identical sibling is available ${ }^{15}$. For the remaining $70 \%$ of the patients, an unrelated HLA matched donor is considered the best option. It was previously shown, that single mismatches at HLA-A, $-B,-C$ and -DRB1 are associated with occurrence of GVHD, transplantation related morbidity and mortality, which emphasizes the need for an $8 / 8 \mathrm{HLA}$ match donor ${ }^{16-19}$. It seems that the presence of a single HLA-DQB1 mismatch was tolerated, although an HLA-DQB1 disparity in addition to mismatches at HLA-A, B, C, or DRB1 was associated with worse outcome ${ }^{18,20}$. Therefore, if possible an 10/10 HLA matched unrelated donor is preferred. If an HLA matched donor is lacking or if the patient's genotype suggest that the search for a matched unrelated donor will be long and difficult, haploidentical hematopoietic family stem cell transplantation could represent an alternative donor source ${ }^{21}$. A haploidentical stem cell donor has various advantages. Since almost all patients have at least one HLA haplotype-mismatched related donor, the donor availability is high and there is easy availability for repeated donation of stem cells. In clinical trials, donor versus recipient NK allogeneic responses are shown highly beneficial as they reduce the risk of disease relapse, do not cause GVHD and significantly improve event-free survival ${ }^{22-24}$. Moreover, in haploidentical family transplantation it is more likely that the minor histocompatibility antigens ( $\mathrm{mHA}$ ) are matched between patient and donor, which decreases the risks of posttransplantation complications. Nevertheless, haploidentical transplantation still remains complicated as the alloreactive T cells from the donor can cause high incidence of graft failure, severe GVHD and non-relapse mortality ${ }^{25,26}$.

Despite of 10/10 HLA matching between patient and donor, still 35-45\% will develop systemic acute $\mathrm{GVHD}^{27}$, emphasizing that other undefined genetic factors play a role. It 
has been proposed that non-HLA genes can affect the patient outcome ${ }^{28-30}$. In addition also $\mathrm{mHA}$ have been suggested to play a role in transplantation complications, however

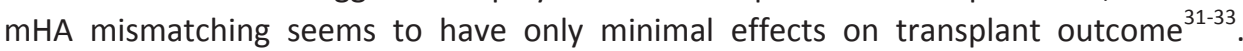
Several studies evaluated the clinical effects of HLA-DP matching ${ }^{34-42}$, and to a lesser extend of HLA-E ${ }^{43-46}$ and have proposed a role for these HLA molecules in stem cell transplantation.

In addition to GVHD, other complications can develop in the various phases after transplantation. To decrease the risk of GVHD the patient will receive excessive immunosuppressiva to prevent donor $T$ cell responses against the patient. Immunosuppressive drugs inhibit immune function by targeting $T$ cell responses through blockage of cellular proliferation ${ }^{47}$. Nevertheless, the absence of an immune response against the patient cells or other pathogenic invaders renders the patient susceptible to bacterial and viral infections ${ }^{48,49}$. As infections severely increase the risk of morbidity and mortality in transplant patients, immune monitoring post-transplantation and identifying factors that can prevent infections from developing are crucial steps to improve patient outcome. HLA is proposed to play a crucial role in the occurrence of infections, however the mechanism is still not fully understood.

It was shown that HLA matching based on high resolution (allele) typing, so determining the DNA sequence, is associated with higher rates of survival following stem cell transplantation $^{18}$. Nevertheless, only for $60-80 \%$ of the patients a 9-10/10 HLA matched donor can be found ${ }^{50}$. Therefore, alternatives for a full HLA match are becoming a necessity. Recently, it has been suggested that not all amino acid differences between patient and donor provoke an alloreactive T cell response. More and more studies show that specific mismatch combinations are associated with less risk of posttransplantation complications or focus on mismatch combinations which should be avoided to protect patient well being ${ }^{51,52}$. Nevertheless, the specific epitopes responsible for $\mathrm{T}$ cell alloreactivity in the patient are still undefined.

\section{HLA-DP and HLA-E}

HLA-DP and HLA-E modulate the immune response by the presentation of peptides to T and/or NK cells. These HLA molecules have been shown to play a role in patient outcome after HSCT. Nevertheless, in contrast to other loci, the functional relevance of these HLA-DP and HLA-E is still unclear and up to now it is unknown how to implement them in patient-donor matching strategies in stem cell transplantation. Functional studies examining the underlying mechanism of the immunomodulatory effects of HLA-E and HLA-DP are essential in order to resolve the role of these HLA molecules in post-transplantation complications.

\subsubsection{The functional and clinical relevance of HLA-DPB1 polymorphism}

Evidence is accumulating describing HLA-DP as an important transplantation antigen. In vitro studies have shown positive mixed lymphocyte reactions (MLR) in cultures that 
were matched for all classical HLA class I and II antigens except for HLA-DPB1 ${ }^{53,54}$. Due to a scarcity in allele specific HLA-DPB1 monoclonal antibodies ${ }^{55}$ and the failure to stimulate consistent responses in primary mixed lymphocyte cultures ${ }^{56,57}$, the HLA-DPB1 expression and molecules could not be studied profoundly and consequences of a patient-donor HLA-DPB1 mismatch could not be established. In addition to the in vitro data, retrospective studies indicated that HLA-DPB1 matching status can seriously affect transplantation outcome in a dual role; on the one hand GVHD and on the other hand graft versus leukemia (GVL) effect ${ }^{51,58,59}$. In case of allele mismatching for HLA-DPB1 and allele matching for HLA-A,-B,-C,-DRB1 and -DQB1 in unrelated HSCT, several studies have shown an increase in the risk of GVHD ${ }^{58-63}$ and/or a decrease in disease relapse $e^{51,61,63,64}$. On the contrary, other studies have indicated that disparity for HLA-DPB1 decreases survival rate, without having an effect on GVHD ${ }^{65}$. Flomenberg et al. (2004) found no effect of HLA-DPB1 matching status on either transplantation related complications nor on disease relapse ${ }^{17}$. To determine a matching procedure for HLA-DP in HSCT however it is necessary to define the functional matching criteria.

\subsubsection{HLA-DPB1 permissive and non-permissive allele groups}

More and more studies are focusing on the identification of the functional HLA-DP epitopes. As it has been published earlier that some HLA-DPB1 mismatches are not associated with deleterious clinical outcome, it has been suggested that certain amino acid residues are less prone to provoke an alloreactive response ${ }^{36,51,66}$. Determining which mismatch combinations are more acceptable than others, regarding alloreactivity, comprises currently a major focus in the field of HLA-DP immunogenicity. The acceptable, so-called permissive, mismatches could be explained by differences at amino acid level which provoke no or a very low alloreactive response. Furthermore, the post-selection $\mathrm{T}$ cell is not able to recognize extensively mismatched MHC molecules as during positive thymic selection the $\mathrm{T}$ cell repertoire is generated with a sufficiently affinity for self-MHC ${ }^{67}$. In the current attempts to classify of HLA-DP permissive and non-permissive mismatches, the mechanism leading to an alloreactive T cell response is not fully understood ${ }^{34,37,68-70}$.

Most studies focused on HLA-DPB1 amino acid substitutions within the hypervariable regions of exon 2 to unravel the role on $T$ and $B$ cell mediated allorecognition and described that specific residues in the pockets of the peptide binding groove play a key role in HLA-DP functioning ${ }^{38,55,71-74}$. The group of Inoko evaluated allele groups based on the fourth, fifth and sixth hypervariable region in exon $2^{75}$, while other groups described relevant roles for other positions within exon $2^{38,73}$. The amino acid variability in this region had also been investigated in disease association studies and showed e.g. a strong correlation between HLA-DPB1 amino acid position 69 in exon 2 and disease status $^{76,77}$. In unrelated stem cell transplantation, a direct correlation between patient outcome and exon 2 epitopes remains to be defined ${ }^{58,62}$. The group of Fleischhauer established an algorithm to determine permissive and non-permissive HLA-DPB1 
combinations, based on functional analysis of alloreactive $\mathrm{T}$ cell cross reactivity patterns ${ }^{36,66}$. This algorithm included four allele groups, in which a mismatch combination based on alleles from one allele group were considered to be associated with low allorecognition (permissive), whereas a mismatch combination based on alleles from different allele groups were associated with a high allorecognition (nonpermissive $)^{36}$. Other groups have defined immunogenic epitopes within the HLA-DPB1 molecule by assigning antibody specificity to the amino acid difference between transplant donor and recipient in organ transplantation. These studies have described immunodominance for hypervariable regions $F$ and $C$ in exon $2^{78,79}$, however, approximately $20 \%$ of the cases with anti-DP reactivity could not be assigned to amino acid variability in the peptide binding groove ${ }^{80}$. Altogether, the amino acid residues encoded by exon 2 HLA-DPB1 could not entirely explain T cell alloreactivity or antibody reactivity, which underscores a role for amino acid residues in other parts of the molecule.

\subsubsection{HLA-DPA1 polymorphism and transplantation}

The HLA-DP alpha chain shows, as compared to the beta chain, limited polymorphism, but still the HLA-DPA1 alleles encode 19 different cell surface proteins. Since the alpha chain received less attention because of the limited polymorphism and high linkage between HLA-DPA1 and HLA-DPB1 ${ }^{81}$, its role in T cell recognition is hardly included in T cell allorecognition studies. Gaston et al. 1997 was the first to describe the influence of polymorphism in the alpha chain on the recognition of HLA-DP restricted T cell clones and suggested an important role for amino acid 31 in peptide binding affinity ${ }^{42}$. In HLA matched unrelated stem cell transplantations, an HLA-DPA1 mismatch was associated with reduced survival and shorter relapse-free survival, whereas a mismatch between patient and donor based on HLA-DPB1 had no effect on patient outcome ${ }^{82}$. These findings underline the potential impact of HLA-DPA1 on T cell alloreactivity and therefore studies on the role of the alpha chain of the HLA-DP molecule on T cell allorecognition can contribute to a better understanding of HLA-DP immunogenicity in transplantation.

\subsubsection{HLA-E as ligand to NK cell receptors}

HLA-E functions as a ligand for activating and inhibiting NK cell receptors and for a subset of T cells. It is expressed in almost all tissues, nevertheless at lower levels then the classical HLA class I molecules. For stable HLA-E surface expression, binding of a restricted set of nonamer peptides is required and the peptides preferably are derived from the signal sequences of the classical HLA class I molecules and HLA-G ${ }^{83-86}$. HLA-E binding peptides require TAP function to enter the ER, therefore HLA-E serves as a remote sensor of TAP function and of classical HLA class I expression. However, HLA-E can also bind peptides from derived from bacteria, viruses and stress proteins suggesting that it can be used by NK cells and T cells to monitor cellular-stress, 
-integrity and -infection ${ }^{87-90}$. The NK cell interacts with HLA-E and the bound peptide via the NKG2A and NKG2C receptors ${ }^{91}$ (Figure 1.4). The NKG2A receptor contains immunoreceptor tyrosine-based inhibitory motifs (ITIM) which constitute an inhibitory signal, whereas NKG2C interacts with DAP-12 resulting in an activation signal. CD94/NKG2A and probably also CD94/NKG2C, binds HLA-E by a key-lock mechanism, whereby the CD94 part is responsible for the interaction, while the NKG2 component of the receptor transmits the signal to intracellular compartments of the immune cell ${ }^{92}$. The inhibitory receptor binds with a six fold higher affinity to HLA-E when compared to NKG2C, probably to prevent auto-reactive killing of healthy cells ${ }^{93-95}$.

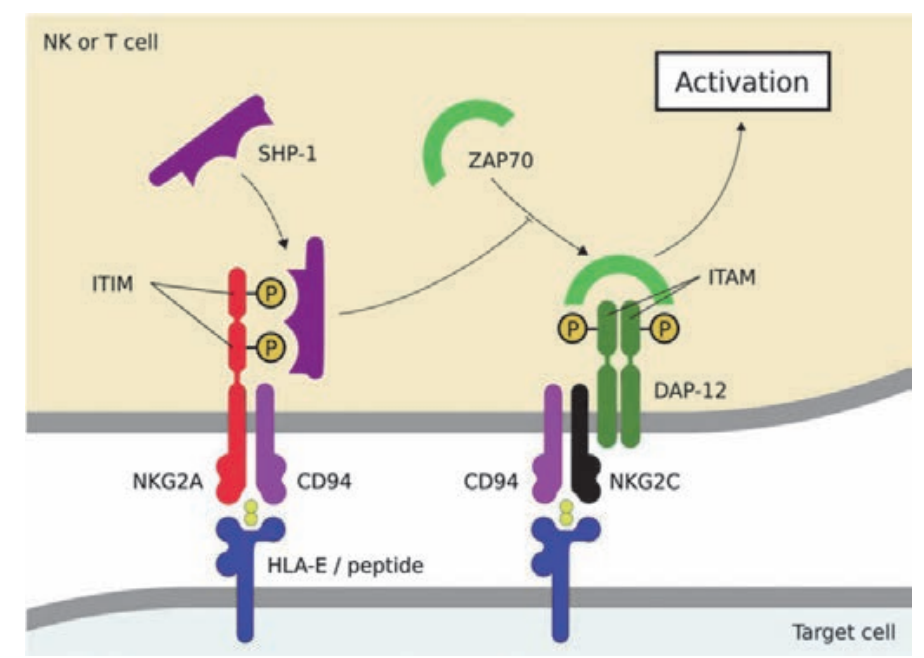

Figure 1.4 Regulation of NK or T cell activation via HLA-E interaction with the inhibitory receptor NKG2A or the activating receptor $\mathrm{NKG} 2 \mathrm{C}^{12}$.

\subsubsection{The functional and clinical relevance of HLA-E polymorphism}

Based on HLA-E transfected cell lines, it has been proposed that the sequence of the peptide bound to $H L A-E^{84,85,89,91,94,96-98}$ and the HLA-E genotype ${ }^{85,96,99}$ determine the level of HLA-E expression. HLA-E is the least polymorphic of all HLA class I alleles with only thirteen alleles encoding five different proteins described in the human population. The alleles HLA-E*01:01 and HLA-E*01:03 differ by a single amino acid on the $\alpha 2$ domain of the HLA-E heavy chain, HLA-E*01:01 encodes an Arg at position 107 were HLA-E*01:03 has a Gly. Both alleles have been detected in the population at high and similar frequencies and have been proposed to be under some form of stabilizing selection ${ }^{100,101}$, which suggests that there may be functional differences between these alleles. Based on the studies with transduced cell lines, it has been suggested that the relatively low levels of surface HLA-E are the result of low affinity- or defective binding 
of endogenous peptides to HLA-E ${ }^{102}$, and that the HLA-E*01:03 encodes for a protein variant with a relatively higher peptide binding affinity than the HLA-E*01:01 variant ${ }^{96}$. This was proposed to be the cause of a higher cell surface expression in HLA-E*01:03, and the latter study also demonstrated that stabilization of HLA-E was dependent on the peptide sequence. The level of HLA-E expression was suggested to be relevant for cell fate as increased HLA-E expression level on cell lines was shown to inhibit the NK cell response via NKG2A interaction. Nevertheless, knowledge on the regulatory mechanisms of HLA-E expression is limited and the role of HLA-E in regulating NK cell function regarding the NKG2A versus the NKG2C expressing subsets requires further investigation $^{85,103,104}$.

Direct functional evidence is limited, but, in the HSCT setting, the HLA-E*01:03 genotype has been shown to confer protection against graft-versus-host disease, relapse and transplantation related mortality, and HLA-E*01:03 is associated with a better survival as compared to the HLA-E*01:01 genotype ${ }^{43,44,46,105}$. In addition, the HLA-E genotype has also been shown to play a role in various diseases ${ }^{106-108}$ and pregnancy $^{109}$.

\subsubsection{The role of HLA-E in viral immunity}

HLA-E in general binds leader peptides derived from other HLA class I molecules which it presents on the cell surface to the NKG2A receptor ${ }^{83,84}$. Therefore, a healthy cell is protected against killing by the NK cells in a NKG2A dependent manner. On normal cells HLA-A, -B and -C molecules are expressed, however many viruses downregulate classical HLA class I in order to evade T cell recognition ${ }^{9}$. This downregulation of classical HLA class I results in a decrease of HLA-E on the surface as the availability of HLA class I derived nonamers to bind to HLA-E drops. The downregulation of HLA-E thereby removes the inhibitory signal for NK cells, making the infected target cell susceptible for NK cell killing. Hence, NKG2A+ NK cell subsets can distinguish selfversus non-self by the presence or absence of HLA-E. The role of the activating NKG2C receptor is less well understood. The NKG2C receptor was proposed to play a role in viral infection as NKG2C+ NK cells are expanded following CMV reactivation and CMV infection in human individuals and in response to CMV infected fibroblasts ${ }^{110-115}$. This subset has a high capacity for target cell induced IFN- $\gamma$ production and preferentially acquires CD57 over time following CMV reactivation. Nonetheless it is not known whether HLA-E is regulating the function of the NKG2C expressing NK cells during viral infection. 


\section{Outline of this thesis}

HLA class I and class II genes of the HLA complex represent the most polymorphic genes of the human genome. Due to this high polymorphism, matching between patient and donor is complex and patient outcome after hematopoietic stem cell transplantation (HSCT) can be variable. Patients and donors of unrelated HSCT are preferably matched for HLA-A, -B, -C and -DRB1 on both chromosomes and if possible also for HLA-DQB1. Despite of the 10/10 HLA matching procedure between patient and donor, still 35-45\% will develop acute GVHD. This emphasizes that other genetic factors also play a role in the occurrence of post-transplantation complications (chapter 1).

HLA-DP and HLA-E modulate the immune response by presenting peptides to $T$ and/or NK cells and have been shown to play a role in patient outcome after HSCT. HLA-DP is characterized by a high polymorphism, nevertheless, the alleles are not correlated to any functional equivalent which may be explanatory for the contradictory patient studies concerning DP mismatching. Defining the molecular mechanism that directs HLA-DP allorecognition is required (chapter 1 ).

The low-polymorphic non-classical HLA class I molecule HLA-E, modulates NK cell function by presentation of self and non-self peptides. Nevertheless, knowledge on the regulatory mechanisms of HLA-E expression is limited and the role of HLA-E in regulating NK cell function regarding the NKG2A versus the NKG2C expressing subsets requires further investigation (chapter 1 ).

HLA-DPB1 polymorphism of the entire coding region has been determined in 148 samples representing 28 different DPB1 alleles from either Black, Caucasian or Oriental origin. Polymorphism has been identified in exons 1, 3, 4 and 5 in addition to the already defined exon 2 polymorphism (chapter 2). Functional assays revealed that polymorphism beyond exon 2 had no apparent effect on CD4+ T cell allorecognition (chapters 3 and 4). Interestingly, CD4+ T cell allorecognition was significantly affected by HLA-DPA1 polymorphism and structural homology modeling identified specific amino acids in the alpha chain as potentially relevant residues for peptide binding or TCR interaction (chapter 4).

HLA-E gene polymorphism was determined (chapter 5) in healthy subjects and transplant patients. The regulatory mechanisms of HLA-E expression and the functional consequences of HLA-E for NKG2A+ and NKG2C+ NK cells were studied in peripheral blood mononuclear cells of healthy individuals. Basal and peptide induced HLA-E surface expression level was higher in HLA-E*01:03 homozygous subjects when compared to HLA-E*01:01 homozygous subjects (chapter 6). Peptide induced HLA-E expression was regulated at translational level as exogenous peptide stimulation induced translation of new HLA-E molecules and translation was inhibited by cycloheximide (chapter 6). Peptide induced HLA-E expression inhibited degranulation of NKG2A+ NK cell subsets with almost all peptides, whereas NKG2C+ NK cell responses were solely induced with $\mathrm{CMV}(\mathrm{I}), \mathrm{A} 80, \mathrm{~B} 13$ and G peptide (chapter 7). HLA-G derived peptide not only induced activation threefold, but also triggered NKG2C receptor 
internalization (chapter 7). In HSCT, the presence of HLA-E*01:03 was associated with higher risk of infections and an HLA-E mismatch was associated with a higher risk of severe acute GVHD (chapter 8 ). The implications of these functional and clinical results are discussed in chapter 9 . 


\section{References}

1. Klein J. Seeds of time: fifty years ago Peter A. Gorer discovered the H-2 complex. Immunogenetics 1986;24:331-8.

2. Klein J. George Snell's first foray into the unexplored territory of the major histocompatibility complex. Genetics 2001;159:435-9.

3. Klein J. Natural history of the Major Histocompatibility Complex. New York: John Wiley \& Sons, 1986.

4. Horton R, Wilming L, Rand V, Lovering RC, Bruford EA, Khodiyar VK, Lush MJ, Povey S, Talbot CC Jr, Wright MW, Wain HM, Trowsdale J, Ziegler A, Beck S. Gene map of the extended human MHC. Nat Rev Genet 2004; 5:889-99.

5. Marsh SGE, Parham P, Barber LD. The HLA Factsbook. San Diego, San Francisco, New York, Boston, London, Sydney, Tokyo: Academic Press, 2000.

6. Neefjes J, Jongsma ML, Paul P, Bakke O. Towards a systems understanding of MHC class I and MHC class II antigen presentation. Nat Rev Immunol 2011;11:823-36.

7. Archbold JK, Ely LK, Kjer-Nielsen L, Burrows SR, Rossjohn J, McCluskey J, Macdonald WA. T cell allorecognition and MHC restriction-A case of Jekyll and Hyde? Mol Immunol 2008;45:583-98.

8. Boyington JC, Sun PD. A structural perspective on MHC class I recognition by killer cell immunoglobulinlike receptors. Mol Immunol 2002;38:1007-21.

9. Lodoen MB, Lanier LL. Viral modulation of NK cell immunity. Nat Rev Microbiol 2005;3:59-69.

10. Bukur J, Jasinski S, Seliger B. The role of classical and non-classical HLA class I antigens in human tumors. Semin Cancer Biol 2012;22:350-8.

11. Finton KA, Strong RK. Structural insights into activation of antiviral NK cell responses. Immunol Rev 2012;250:239-57.

12. Iwaszko M, Bogunia-Kubik K. Clinical significance of the HLA-E and CD94/NKG2 interaction. Arch Immunol Ther Exp (Warsz) 2011;59:353-67.

13. Robinson J, Halliwell JA, McWilliam H, Lopez R, Parham P, Marsh SG. The IMGT/HLA database. Nucleic Acids Res 2013;41:D1222-7.

14. Eiz-Vesper B, Blasczyk R. Relevance of HLA expression Variants in Stem Cell Transplantation. New Advances in Stem Cell Transplantation: InTech, 2012:39-58.

15. Petersdorf EW. Optimal HLA matching in hematopoietic cell transplantation. Curr Opin Immunol 2008; 20:588-93.

16. Arora M, Weisdorf DJ, Spellman SR, Haagenson MD, Klein JP, Hurley CK, Selby GB, Antin JH, Kernan NA, Kollman C, Nademanee A, McGlave P, Horowitz MM, Petersdorf EW. HLA-Identical Sibling Compared With 8/8 Matched and Mismatched Unrelated Donor Bone Marrow Transplant for Chronic Phase Chronic Myeloid Leukemia. J Clin Oncol 2009;27:1644-52.

17. Flomenberg N, Baxter-Lowe LA, Confer D, Fernandez-Vina M, Filipovich A, Horowitz M, Hurley C, Kollman C, Anasetti C, Noreen H, Begovich A, Hildebrand W, Petersdorf E, Schmeckpeper B, Setterholm M, Trachtenberg E, Williams T, Yunis E, Weisdorf D. Impact of HLA class I and class II high-resolution matching on outcomes of unrelated donor bone marrow transplantation: HLA-C mismatching is associated with a strong adverse effect on transplantation outcome. Blood 2004;104:1923-30.

18. Lee SJ, Klein J, Haagenson M, Baxter-Lowe LA, Confer DL, Eapen M, Fernandez-Vina M, Flomenberg N, Horowitz M, Hurley CK, Noreen H, Oudshoorn M, Petersdorf E, Setterholm M, Spellman S, Weisdorf D, Williams TM, Anasetti C. High-resolution donor-recipient HLA matching contributes to the success of unrelated donor marrow transplantation. Blood 2007;110:4576-83.

19. Woolfrey A, Klein JP, Haagenson M, Spellman S, Petersdorf E, Oudshoorn M, Gajewski J, Hale GA, Horan J, Battiwalla M, Marino SR, Setterholm M, Ringden O, Hurley C, Flomenberg N, Anasetti C, FernandezVina $M$, Lee SJ. HLA-C antigen mismatch is associated with worse outcome in unrelated donor peripheral blood stem cell transplantation. Biol Blood Marrow Transplant 2011;17: 885-92.

20. Petersdorf EW, Anasetti C, Martin PJ, Gooley T, Radich J, Malkki M, Woolfrey A, Smith A, Mickelson E, Hansen JA. Limits of HLA mismatching in unrelated hematopoietic cell transplantation. Blood 2004;104:2976-80.

21. Locatelli F, Pende D, Mingari MC, Bertaina A, Falco M, Moretta A, Moretta L. Cellular and molecular basis of haploidentical hematopoietic stem cell transplantation in the successful treatment of high-risk leukemias: role of alloreactive NK cells. Front Immunol 2013;4:15. 
22. Ruggeri L, Capanni M, Urbani E, Perruccio K, Shlomchik WD, Tosti A, Posati S, Rogaia D, Frassoni F, Aversa F, Martelli MF, Velardi A. Effectiveness of donor natural killer cell alloreactivity in mismatched hematopoietic transplants. Science 2002;295:2097-100.

23. Baron F, Petersdorf EW, Gooley T, Sandmaier BM, Malkki M, Chauncey TR, Maloney DG, Storb R. What is the role for donor natural killer cells after nonmyeloablative conditioning? Biol Blood Marrow Transplant 2009;15:580-8.

24. Ruggeri L, Mancusi A, Burchielli E, Perruccio K, Aversa F, Martelli MF, Velardi A. Natural killer cell recognition of missing self and haploidentical hematopoietic transplantation. Semin Cancer Biol 2006;16:404-11.

25. Petersdorf EW, Malkki M, Gooley TA, Martin PJ, Guo Z. MHC haplotype matching for unrelated hematopoietic cell transplantation. PLoS Med 2007;4:e8.

26. Fuchs EJ. Haploidentical transplantation for hematologic malignancies: where do we stand? Hematology Am Soc Hematol Educ Program 2012:230-6.

27. Ferrara JL, Levine JE, Reddy P, Holler E. Graft-versus-host disease. Lancet 2009;373:1550-61.

28. Bettens F, Passweg J, Schanz U, Chalandon Y, Heim D, Güngör T, Stussi G, Nicoloso G, Baldomero H, Gratwohl A, Tiercy JM. Impact of HLA-DPB1 haplotypes on outcome of 10/10 matched unrelated hematopoietic stem cell donor transplants depends on MHC-linked microsatellite polymorphisms. Biol Blood Marrow Transplant 2012;18:608-16.

29. Tseng LH, Storer B, Petersdorf E, Lin MT, Chien JW, Grogan BM, Malkki M, Chen PJ, Zhao LP, Martin PJ, Hansen JA IL10 and IL10 receptor gene variation and outcomes after unrelated and related hematopoietic cell transplantation. Transplantation 2009;87:704-10.

30. Newell LF, Gooley T, Hansen JA, Stirewalt DL, Petersdorf EW, Deeg HJ. Tumor necrosis factor polymorphism affects transplantation outcome in patients with myelodysplastic syndrome but not in those with chronic myelogenous leukemia, independent of the presence of HLA-DR15. Biol Blood Marrow Transplant 2010;16:1700-6.

31. Sellami MH, Torjemane L, Arias AE, Kaabi H, Ladeb S, Poli F, Othmane TB, Hmida S. Does minor histocompatibility antigen HA-1 disparity affect the occurrence of graft-versus-host disease in tunisian recipients of hematopoietic stem cells? Clinics (Sao Paulo) 2010;65:1099-103.

32. Akatsuka Y, Warren EH, Gooley TA, Brickner AG, Lin MT, Hansen JA, Martin PJ, Madtes DK, Engelhard VH, Takahashi T, Riddell SR. Disparity for a newly identified minor histocompatibility antigen, HA-8, correlates with acute graft-versus-host disease after haematopoietic stem cell transplantation from an HLA-identical sibling. Br J Haematol 2003;123:671-5.

33. Gallardo D, Aróstegui JI, Balas A, Torres A, Caballero D, Carreras E, Brunet S, Jiménez A, Mataix R, Serrano D, Vallejo C, Sanz G, Solano C, Rodríguez-Luaces M, Marín J, Baro J, Sanz C, Román J, González M, Martorell J, Sierra J, Martín C, de la Cámara R, Grañena A; GvHD Subcommittee of the Grupo Español de Trasplante Hemapoyético (GETH).Disparity for the minor histocompatibility antigen HA-1 is associated with an increased risk of acute graft-versus-host disease (GvHD) but it does not affect chronic GvHD incidence, disease-free survival or overall survival after allogeneic human leucocyte antigen-identical sibling donor transplantation. Br J Haematol 2001;114:931-6.

34. Zino E, Frumento G, Marktel S, Sormani MP, Ficara F, Di Terlizzi S, Parodi AM, Sergeant R, Martinetti M, Bontadini A, Bonifazi F, Lisini D, Mazzi B, Rossini S, Servida P, Ciceri F, Bonini C, Lanino E, Bandini G, Locatelli F, Apperley J, Bacigalupo A, Ferrara GB, Bordignon C, Fleischhauer K. A T-cell epitope encoded by a subset of HLA-DPB1 alleles determines nonpermissive mismatches for hematologic stem cell transplantation. Blood 2004;103: 1417-24.

35. Ludajic K, Balavarca Y, Bickeböller H, Pohlreich D, Kouba M, Dobrovolna M, Vrana M, Rosenmayr A, Fischer GF, Fae I, Kalhs P, Greinix HT. Impact of HLA-DPB1 allelic and single amino acid mismatches on HSCT. Br J Haematol 2008;142:436-43.

36. Crocchiolo R, Zino E, Vago L, Oneto R, Bruno B, Pollichieni S, Sacchi N, Sormani MP, Marcon J, Lamparelli T, Fanin R, Garbarino L, Miotti V, Bandini G, Bosi A, Ciceri F, Bacigalupo A, Fleischhauer K; Gruppo Italiano Trapianto di Midollo Osseo, Cellule Staminale Ematopoietiche (CSE) e Terapia Cellulare; Italian Bone Marrow Donor Registry. Nonpermissive HLA-DPB1 disparity is a significant independent risk factor for mortality after unrelated hematopoietic stem cell transplantation. Blood 2009;114:143744. 
37. Fleischhauer K, Shaw BE, Gooley T, Malkki M, Bardy P, Bignon JD, Dubois V, Horowitz MM, Madrigal JA, Morishima Y, Oudshoorn M, Ringden O, Spellman S, Velardi A, Zino E, Petersdorf EW; International Histocompatibility Working Group in Hematopoietic Cell Transplantation. Effect of T-cell-epitope matching at HLA-DPB1 in recipients of unrelated-donor haemopoietic-cell transplantation: a retrospective study. Lancet Oncol 2012;13: 366-74.

38. Cesbron A, Moreau P, Cheneau ML, Cury S, Milpied N, Muller JY, Harousseau JL, Bignon JD. Crucial role of the third and fourth hypervariable regions of HLA-DPB1 allelic sequences in primary mixedlymphocyte reaction: application in allogeneic bone marrow transplantation. Transplant Proc 1993;25:1232-3.

39. Díaz G, Amicosante M, Jaraquemada D, Butler RH, Guillén MV, Sánchez M, Nombela C, Arroyo J. Functional analysis of HLA-DP polymorphism: a crucial role for DPbeta residues 9, 11, 35, 55, 56, 69 and 84-87 in T cell allorecognition and peptide binding. Int Immunol 2003;15:565-76.

40. Rutten CE, van Luxemburg-Heijs SA, Halkes CJ, van Bergen CA, Marijt EW, Oudshoorn M, Griffioen M, Falkenburg JH. Patient HLA-DP-specific CD4+ T cells from HLA-DPB1-mismatched donor lymphocyte infusion can induce graft-versus-leukemia reactivity in the presence or absence of graft-versus-host disease. Biol Blood Marrow Transplant 2013;19:40-8.

41. Varney MD, Lester S, McCluskey J, Gao X, Tait BD. Matching for HLA DPA1 and DPB1 alleles in unrelated bone marrow transplantation. Hum Immunol 1999;60:532-8.

42. Gaston JS, Goodall JC, Young JL, Young SP. Effect of polymorphism of the HLA-DPA1 chain on presentation of antigenic peptides. Hum Immunol 1997;54:40-7.

43. Tamouza R, Busson M, Rocha V, Fortier C, Haddad Y, Brun M, Boukouaci W, Bleux H, Socié G, Krishnamoorthy R, Toubert A, Gluckman E, Charron D. Homozygous status for HLA-E*0103 confers protection from acute graft-versus-host disease and transplant-related mortality in HLA-matched sibling hematopoietic stem cell transplantation. Transplantation 2006;82:1436-40.

44. Tamouza R, Rocha V, Busson M, Fortier C, El Sherbini SM, Esperou H, Filion A, Socié G, Dulphy N, Krishnamoorthy R, Toubert A, Gluckman E, Charron D. Association of HLA-E polymorphism with severe bacterial infection and early transplant-related mortality in matched unrelated bone marrow transplantation. Transplantation 2005;80:140-4.

45. Hosseini E, Schwarer AP, Ghasemzadeh M. The impact of HLA-E polymorphisms in graft-versus-host disease following HLA-E matched allogeneic hematopoietic stem cell transplantation. Iran J Allergy Asthma Immunol 2012;11:15-21.

46. Ludajic K, Rosenmayr A, Faé I, Fischer GF, Balavarca Y, Bickeböller H, Kalhs P, Greinix HT. Association of HLA-E polymorphism with the outcome of hematopoietic stem-cell transplantation with unrelated donors. Transplantation 2009;88:1227-8.

47. Seggewiss R, Lore K, Greiner E, et al. Imatinib inhibits T-cell receptor-mediated T-cell proliferation and activation in a dose-dependent manner. Blood 2005;105:2473-9.

48. Hambach L, Stadler M, Dammann E, Ganser A, Hertenstein B. Increased risk of complicated CMV infection with the use of mycophenolate mofetil in allogeneic stem cell transplantation. Bone Marrow Transplant 2002;29:903-6.

49. Boeckh M, Leisenring W, Riddell SR, Bowden RA, Huang ML, Myerson D, Stevens-Ayers T, Flowers ME, Cunningham T, Corey L. Late cytomegalovirus disease and mortality in recipients of allogeneic hematopoietic stem cell transplants: importance of viral load and T-cell immunity. Blood 2003;101: 407-14.

50. Tiercy JM. Unrelated hematopoietic stem cell donor matching probability and search algorithm. Bone Marrow Res 2012;2012:695018.

51. Kawase T, Matsuo K, Kashiwase K, Inoko H, Saji H, Ogawa S, Kato S, Sasazuki T, Kodera Y, Morishima Y; Japan Marrow Donor Program. HLA mismatch combinations associated with decreased risk of relapse: implications for the molecular mechanism. Blood 2009;113:2851-8.

52. Kawase T, Morishima Y, Matsuo K, Kashiwase K, Inoko H, Saji H, Kato S, Juji T, Kodera Y, Sasazuki T; Japan Marrow Donor Program. High-risk HLA allele mismatch combinations responsible for severe acute graft-versus-host disease and implication for its molecular mechanism. Blood 2007;110: 2235-41.

53. Shaw S, Johnson AH, Shearer GM. Evidence for a new segregant series of $B$ cell antigens that are encoded in the HLA-D region and that stimulate secondary allogenic proliferative and cytotoxic responses. J Exp Med 1980;152:565-80. 
54. Termijtelen A, Khan PM, Shaw S, Rood van JJ. Mapping SB in relation to HLA and GL01 using cells from first-cousin marriage offspring. Immunogenetics 1983;18:503-12.

55. Marshall WH, Drover S, Codner D, Gamberg J, Copp MD, Liu HW, Deng LT, Younghusband HB. HLA-DP epitope typing using monoclonal antibodies. Hum Immunol 1998;59:189-97.

56. Farrell C, Honeyman M, Hoadley C. An analysis of the effect of HLA-DP in the mixed lymphocyte reaction. J Immunogenet 1988;15:243-50.

57. Olerup O, Moller E, Persson U. HLA-DP incompatibilities induce significant proliferation in primary mixed lymphocyte cultures in HLA-A, -B, -DR and -DQ compatible individuals: implications for allogeneic bone marrow transplantation. Tissue Antigens 1990;36:194-202.

58. Ludajic K, Balavarca Y, Bickeböller H, Pohlreich D, Kouba M, Dobrovolna M, Vrana M, Rosenmayr A, Fischer GF, Fae I, Kalhs P, Greinix HT. Impact of HLA-DPB1 allelic and single amino acid mismatches on HSCT. Br J Haematol 2008;142:436-43.

59. Petersdorf EW, Gooley T, Malkki M, Anasetti C, Martin P, Woolfrey A, Smith A, Mickelson E, Hansen JA. The biological significance of HLA-DP gene variation in haematopoietic cell transplantation. Brit J Haematol 2001;112:988-94.

60. Varney MD, Lester S, McCluskey J, Gao X, Tait BD. Matching for HLA DPA1 and DPB1 alleles in unrelated bone marrow transplantation. Hum Immunol 1999;60:532-8.

61. Shaw BE, Gooley TA, Malkki M, Madrigal JA, Begovich AB, Horowitz MM, Gratwohl A, Ringdén O, Marsh SG, Petersdorf EW. The importance of HLA-DPB1 in unrelated donor hematopoietic cell transplantation. Blood 2007; 110:4560-6.

62. Loiseau P, Espérou H, Busson M, Sghiri R, Tamouza R, Hilarius M, Raffoux C, Devergie A, Ribaud P, Socié G, Gluckman E, Charron D. DPB1 disparities contribute to severe GVHD and reduced patient survival after unrelated donor bone marrow transplantation. Bone Marrow Transplant 2002;30: 497-502.

63. Shaw BE, Potter MN, Mayor NP, Pay AL, Smith C, Goldman JM, Prentice HG, Marsh SG, Madrigal JA. The degree of matching at HLA-DPB1 predicts for acute graft-versus-host disease and disease relapse following haematopoietic stem cell transplantation. Bone Marrow Transplant 2003;31:1001-8.

64. Shaw BE, Marsh SG, Mayor NP, Russell NH, Madrigal JA. HLA-DPB1 matching status has significant implications for recipients of unrelated donor stem cell transplants. Blood 2006;107:1220-6.

65. Shaw BE, Mayor NP, Russell NH, Apperley JF, Clark RE, Cornish J, Darbyshire P, Ethell ME, Goldman JM, Little AM, Mackinnon S, Marks DI, Pagliuca A, Thomson K, Marsh SG, Madrigal JA. Diverging effects of HLA-DPB1 matching status on outcome following unrelated donor transplantation depending on disease stage and the degree of matching for other HLA alleles. Leukemia 2010;24:58-65.

66. Zino E, Frumento G, Marktel S, Sormani MP, Ficara F, Di Terlizzi S, Parodi AM, Sergeant R, Martinetti M, Bontadini A, Bonifazi F, Lisini D, Mazzi B, Rossini S, Servida P, Ciceri F, Bonini C, Lanino E, Bandini G, Locatelli F, Apperley J, Bacigalupo A, Ferrara GB, Bordignon C, Fleischhauer K. A T-cell epitope encoded by a subset of HLA-DPB1 alleles determines nonpermissive mismatches for hematologic stem cell transplantation. Blood 2004;103: 1417-24.

67. Heemskerk MB, Roelen DL, Dankers MK, van Rood JJ, Claas FH, Doxiadis II, Oudshoorn M. Allogeneic $\mathrm{MHC}$ class I molecules with numerous sequence differences do not elicit a CTL response. Hum Immunol 2005;66:969-76.

68. Rutten CE, van Luxemburg-Heijs SA, van der Meijden ED, Griffioen M, Oudshoorn M, Willemze R, Falkenburg JH. HLA-DPB1 mismatching results in the generation of a full repertoire of HLA-DPB1specific CD4+ T cell responses showing immunogenicity of all HLA-DPB1 alleles. Biol Blood Marrow Transplant 2010;16:1282-92.

69. Rutten $C E$, van Luxemburg-Heijs SA, van der Meijden ED, Griffioen M, Oudshoorn M, Willemze R, Falkenburg JH. Both permissive and nonpermissive HLA-DPB1 mismatches can induce polyclonal HLADPB1 specific immune responses in vivo and in vitro. Blood 2010;115:151-3.

70. Vie H, Gaschet J, Milpied N. Permissive, nonpermissive HLA-DPB1 epitope disparities and the specificity of T cells infiltrating the skin during acute graft-versus-host disease. Blood 2011;117: 5779-81.

71. Cesbron A, Moreau P, Milpied N, Harousseau JL, Muller JY, Bignon JD. Crucial role of the third and fourth hypervariable regions of HLA-DPB1 allelic sequences in the mixed lymphocyte reaction. Hum Immunol 1992;33:202-7.

72. Díaz G, Catálfamo M, Coiras MT, Alvarez AM, Jaraquemada D, Nombela C, Sánchez-Pérez M, Arroyo J. HLA-DP beta residue 69 plays a crucial role in allorecognition. Tissue Antigens 1998;52:27-36. 
73. Díaz G, Amicosante M, Jaraquemada D, Butler RH, Guillén MV, Sánchez M, Nombela C, Arroyo J. Functional analysis of HLA-DP polymorphism: a crucial role for DPbeta residues 9, 11, 35, 55, 56, 69 and 84-87 in T cell allorecognition and peptide binding. Int Immunol 2003;15:565-76.

74. Nicholson I, Varney M, Kanaan C, Grigg A, Szer J, Tiedemann K, Tait BD. Alloresponses to HLA-DP detected in the primary MLR: correlation with a single amino acid difference. Hum Immunol 1997;55: 163-9.

75. Naruse TK, Nose Y, Kagiya M, Liao G, Nabeya N, Kimura M, Isshiki G, Inoko H. Cloned primed lymphocyte test cells recognize the fourth, fifth, and sixth hypervariable regions at amino acid positions 65-87 of the DPB1 molecule. Hum Immunol 1995; 42:123-30.

76. Richeldi L, Sorrentino R, Saltini C. HLA-DPB1 glutamate 69: a genetic marker of beryllium disease. Science 1993;262:242-4.

77. Rossman MD, Stubbs J, Lee CW, Argyris E, Magira E, Monos D. Human leukocyte antigen class II amino acid epitopes. Am J Resp Crit Care Med 2002;165:788-94.

78. Duquesnoy RJ, Awadalla Y, Lomago J, Jelinek L, Howe J, Zern D, Hunter B, Martell J, Girnita A, Zeevi A. Retransplant candidates have donor-specific antibodies that react with structurally defined HLA-DR, DQ, DP epitopes. Transpl Immunol 2008;18:352-60.

79. Cano P, Fernandez-Vina M. Two sequence dimorphisms of DPB1 define the immunodominant serologic epitopes of HLA-DP. Hum Immunol 2009;70:836-43.

80. Billen EV, Christiaans MH, Doxiadis, II, Voorter CE, van den Berg-Loonen EM. HLA-DP antibodies before and after renal transplantation. Tissue Antigens 2010;75:278-85.

81. Begovich AB, Moonsamy PV, Mack SJ, Barcellos LF, Steiner LL, Grams S, Suraj-Baker V, Hollenbach J, Trachtenberg E, Louie L, Zimmerman P, Hill AV, Stoneking M, Sasazuki T, Konenkov VI, Sartakova ML, Titanji VP, Rickards O, Klitz W. Genetic variability and linkage disequilibrium within the HLA-DP region: analysis of 15 different populations. Tissue Antigens 2001;57:424-39.

82. Schaffer M, Aldener-Cannavá, Remberger M, Ringdén O, Olerup O. Roles of HLA-B, HLA-C and HLADPA1 incompatibilities in the outcome of unrelated stem-cell transplantation. Tissue Antigens 2003; 62:243-50.

83. Lee $\mathrm{N}$, Llano M, Carretero M, Ishitani A, Navarro F, López-Botet M, Geraghty DE. HLA-E is a major ligand for the natural killer inhibitory receptor CD94/NKG2A. Proc Natl Acad Sci U S A. 1998;95: 5199-204.

84. Lee N, Goodlett DR, Ishitani A, Marquardt H, Geraghty DE. HLA-E surface expression depends on binding of TAP-dependent peptides derived from certain HLA class I signal sequences. J Immunol 1998; 160:4951-60.

85. Maier S, Grzeschik M, Weiss EH, Ulbrecht M. Implications of HLA-E allele expression and different HLA-E ligand diversity for the regulation of NK cells. Hum Immunol 2000;61:1059-65.

86. Mazzarino P, Pietra G, Vacca P, Falco M, Colau D, Coulie P, Moretta L, Mingari MC. Identification of effector-memory CMV-specific T lymphocytes that kill CMV-infected target cells in an HLA-E-restricted fashion. Eur J Immunol 2005;35:3240-7.

87. Ulbrecht M, Martinozzi S, Grzeschik M, Hengel H, Ellwart JW, Pla M, Weiss EH. Cutting edge: the human cytomegalovirus UL40 gene product contains a ligand for HLA-E and prevents NK cell-mediated lysis. J Immunol 2000;164:5019-22.

88. Heinzel AS, Grotzke JE, Lines RA, Lewinsohn DA, McNabb AL, Streblow DN, Braud VM, Grieser HJ, Belisle JT, Lewinsohn DM. HLA-E-dependent presentation of Mtb-derived antigen to human CD8+ T cells. J Exp Med 2002;196:1473-81.

89. Michaelsson J, Teixeira de Matos C, Achour A, Lanier LL, Karre K, Soderstrom K. A signal peptide derived from hsp60 binds HLA-E and interferes with CD94/NKG2A recognition. J Exp Med 2002;196: 1403-14.

90. Marín R, Ruiz-Cabello F, Pedrinaci S, Méndez R, Jiménez P, Geraghty DE, Garrido F. Analysis of HLA-E expression in human tumors. Immunogenetics 2003;54:767-75.

91. Braud VM, Allan DS, O'Callaghan CA, Söderström K, D'Andrea A, Ogg GS, Lazetic S, Young NT, Bell Jl, Phillips JH, Lanier LL, McMichael AJ. HLA-E binds to natural killer cell receptors CD94/NKG2A, B and C. Nature 1998;391:795-9.

92. Sullivan LC, Clements CS, Beddoe T, Johnson D, Hoare HL, Lin J, Huyton T, Hopkins EJ, Reid HH, Wilce MC, Kabat J, Borrego F, Coligan JE, Rossjohn J, Brooks AG. The heterodimeric assembly of the CD94NKG2 receptor family and implications for human leukocyte antigen-E recognition. Immunity 2007; 27:900-11. 
93. Kaiser BK, Pizarro JC, Kerns J, Strong RK. Structural basis for NKG2A/CD94 recognition of HLA-E. Proc Natl Acad Sci U S A. 2008;105:6696-701.

94. Llano M, Lee N, Navarro F, García P, Albar JP, Geraghty DE, López-Botet M. HLA-E-bound peptides influence recognition by inhibitory and triggering CD94/NKG2 receptors: preferential response to an HLA-G-derived nonamer. Eur J Immunol 1998;28:2854-63.

95. Kaiser BK, Barahmand-Pour F, Paulsene W, Medley S, Geraghty DE, Strong RK. Interactions between NKG2x immunoreceptors and HLA-E ligands display overlapping affinities and thermodynamics. J Immunol 2005;174:2878-84.

96. Strong RK, Holmes MA, Li P, Braun L, Lee N, Geraghty DE. HLA-E allelic variants. Correlating differential expression, peptide affinities, crystal structures, and thermal stabilities. J Biol Chem 2003;278: 5082-90.

97. Miller JD, Weber DA, Ibegbu C, Pohl J, Altman JD, Jensen PE. Analysis of HLA-E peptide-binding specificity and contact residues in bound peptide required for recognition by CD94/NKG2. J Immunol 2003;171:1369-75.

98. Cheent KS, Jamil KM, Cassidy S, Liu M, Mbiribindi B, Mulder A, Claas FH, Purbhoo MA, Khakoo SI. Synergistic inhibition of natural killer cells by the nonsignaling molecule CD94. Proc Natl Acad Sci U SA. 2013;110:16981-6.

99. Ulbrecht M, Couturier A, Martinozzi S, Pla M, Srivastava R, Peterson PA, Weiss EH. Cell surface expression of HLA-E: interaction with human beta2-microglobulin and allelic differences. Eur J Immunol 1999;29:537-47.

100. Geraghty DE, Stockschleader M, Ishitani A, Hansen JA. Polymorphism at the HLA-E locus predates most HLA-A and -B polymorphism. Hum Immunol 1992;33:174-84.

101. Grimsley C, Ober C. Population genetic studies of HLA-E: evidence for selection. Hum Immunol 1997; 52:33-40.

102. Ulbrecht M, Kellermann J, Johnson JP, Weiss EH. Impaired intracellular transport and cell surface expression of nonpolymorphic HLA-E: evidence for inefficient peptide binding. J Exp Med 1992;176: 1083-90.

103. Brooks AG, Borrego F, Posch PE, Patamawenu A, Scorzelli CJ, Ulbrecht M, Weiss EH, Coligan JE. Specific recognition of HLA-E, but not classical, HLA class I molecules by soluble CD94/NKG2A and NK cells. J Immunol 1999;162:305-13.

104. Vales-Gomez M, Reyburn HT, Erskine RA, Lopez-Botet M, Strominger JL. Kinetics and peptide dependency of the binding of the inhibitory NK receptor CD94/NKG2-A and the activating receptor CD94/NKG2-C to HLA-E. Embo J 1999;18:4250-60.

105. Danzer M, Polin H, Pröll J, Haunschmid R, Hofer K, Stabentheiner S, Hackl C, Kasparu H, König J, Hauser $H$, Binder M, Weiss R, Gabriel C, Krieger O. Clinical significance of HLA-E*0103 homozygosity on survival after allogeneic hematopoietic stem-cell transplantation. Transplantation 2009;88:528-32.

106. Tamouza R, Busson M, Fortier C, Diagne I, Diallo D, Sloma I, Contouris H, Krishnamoorthy R, Labie D, Girot R, Charron D. HLA-E*0101 allele in homozygous state favors severe bacterial infections in sickle cell anemia. Hum Immunol 2007;68:849-53.

107. Park KS, Park JS, Nam JH, Bang D, Sohn S, Lee ES. HLA-E*0101 and HLA-G*010101 reduce the risk of Behcet's disease. Tissue Antigens 2007;69:139-44.

108. Schulte D, Vogel M, Langhans B, Krämer B, Körner C, Nischalke HD, Steinberg V, Michalk M, Berg T, Rockstroh JK, Sauerbruch T, Spengler U, Nattermann J. The HLA-E(R)/HLA-E(R) genotype affects the natural course of hepatitis $\mathrm{C}$ virus (HCV) infection and is associated with HLA-E-restricted recognition of an HCV-derived peptide by interferon-gamma-secreting human CD8(+) T cells. J Infect Dis. 2009;200:1397-401.

109. Mosaad YM, Abdel-Dayem Y, El-Deek BS, El-Sherbini SM. Association between HLA-E *0101 homozygosity and recurrent miscarriage in Egyptian women. Scand J Immunol 2011;74:205-9.

110. Gumá M, Budt M, Sáez A, Brckalo T, Hengel H, Angulo A, López-Botet M. Expansion of CD94/NKG2C+ NK cells in response to human cytomegalovirus-infected fibroblasts. Blood 2006;107:3624-31.

111. Gumá M, Busch LK, Salazar-Fontana LI, Bellosillo B, Morte C, García P, López-Botet M. The CD94/NKG2C killer lectin-like receptor constitutes an alternative activation pathway for a subset of CD8+ T cells. Eur J Immunol 2005;35:2071-80.

112. Lopez-Vergès S, Milush JM, Schwartz BS, Pando MJ, Jarjoura J, York VA, Houchins JP, Miller S, Kang SM, Norris PJ, Nixon DF, Lanier LL. Expansion of a unique CD57NKG2Chi natural killer cell subset during acute human cytomegalovirus infection. Proc Natl Acad Sci U S A. 2011;108:14725-32. 
113. Muñoz-Cobo B, Solano C, Benet I, Costa E, Remigia MJ, de la Cámara R, Nieto J, López J, Amat P, GarciaNoblejas A, Bravo D, Clari MÁ, Navarro D. Functional profile of cytomegalovirus (CMV)-specific CD8(+) T cells and kinetics of NKG2C(+) NK Cells associated with the resolution of CMV DNAemia in allogeneic stem cell transplant recipients. J Med Virol 2012;84:259-67.

114. Béziat V, Dalgard O, Asselah T, Halfon P, Bedossa P, Boudifa A, Hervier B, Theodorou I, Martinot M, Debré P, Björkström NK, Malmberg KJ, Marcellin P, Vieillard V. CMV drives clonal expansion of NKG2C+ NK cells expressing self-specific KIRs in chronic hepatitis patients. Eur J Immunol. 2012;42:447-57.

115. Foley B, Cooley S, Verneris MR, Curtsinger J, Luo X, Waller EK, Anasetti C, Weisdorf D, Miller JS. Human cytomegalovirus (CMV)-induced memory-like NKG2C(+) NK cells are transplantable and expand in vivo in response to recipient CMV antigen. J Immunol. 2012; 189:5082-8. 



\section{Chapter 2}

Full length HLA-DPB1 diversity in multiple alleles of individuals from Caucasian, Black or Oriental origin

Nina Lauterbach, Christina E.M Voorter, Cécile M.H.A Stallinga, Mathijs Groeneweg, Lotte Wieten, Marcel G.J Tilanus 


\section{Abstract}

Despite DP antigens have been shown to be stimulators of the mixed lymphocyte reaction, HLADPB1 is not considered in the matching criteria for hematopoietic stem cell transplantation (HSCT). The role of DPB1 matching in HSCT remains inconclusive due to contradictory findings in different studies. The concept of permissible and non-permissible mismatches might clarify these contradictory results. Although several groups have attempted to identify immunogenic epitopes in exon 2 to establish permissive and non-permissive allele groups, the direct correlation between individual exon 2 amino acids and epitopes with DPB1 immunogenicity is still not evident. We hypothesize that polymorphism within the entire molecule, including polymorphic variability in different ethnic groups, is crucial to unravel the function of DPB1 polymorphism. Using an RNA based approach we sequenced all frequent and available non-frequent DPB1 alleles full length from 148 samples representing 28 different DPB1 alleles from either Black, Caucasian or Oriental origin. We identified various DPB1 alleles with, in addition to the exon 2 polymorphism, polymorphisms in exons 1, 3, 4 and 5 . Based on this polymorphism outside exon 2 we defined one new allele. Two alleles with identical exon 2 polymorphism but differing outside exon 2 were identified in individuals of different ethnic groups. As T cell binding is not restricted to the polymorphic groove and polymorphism in the beta-2 domain of the DP molecule affects CD4 interaction, full length polymorphism should be considered to determine immunogenicity. Eventually, this knowledge will provide new insights in the classification of DPB1 polymorphism and more importantly will add new perspectives to the concept of permissiveness in transplantation. 


\section{Introduction}

Hematopoietic stem cell transplantation (HSCT) has increasingly been used as a therapeutic approach for treating haematological and oncological diseases. One of the main caveats of HSCT is the histocompatibility barrier between recipient and donor, which could lead to graft-versus-host-disease (GVHD) or graft rejection ${ }^{1}$. Previous studies have shown that alloreactive $T$ cells can recognize as little as one amino acid difference in Human Leukocyte Antigen (HLA) between recipient and donor ${ }^{2}$. Current recommendations for matching in unrelated HSCT include matching at the highresolution typing level for HLA-A,-B,-C,-DRB1 and -DQB1, although the requirement of matching for HLA-DQB1 is still under discussion ${ }^{3-5}$. The HLA class II molecule HLA-DP consists of an alpha chain, encoded by the HLA-DPA1 gene and a beta chain encoded by the HLA-DPB1 gene. HLA-DPA1 and -DPB1 are not considered in matching strategies. Matching for DP is difficult because of the weak linkage disequilibrium between HLA-DP and HLA-DR and $-D Q$ and the extensive polymorphism of the DPB alleles. Therefore unrelated HSCT is generally performed across allelic DPB1 mismatches ${ }^{6,7}$.

Despite DPB1 is not considered in the matching procedure for $\mathrm{HSCT}$, evidence is accumulating that DPB1 is important for transplantation outcome. In vitro studies have shown positive mixed lymphocyte reactions (MLR) in cultures that were matched for all classical HLA class I and II antigens except for HLA-DPB ${ }^{8,9}$. Due to a scarcity in allele specific DPB1 monoclonal antibodies ${ }^{10}$ and the failure to stimulate consistent responses in primary mixed lymphocyte cultures ${ }^{11,12}$, the DPB1 expression and molecules could not be studied profoundly and consequences of a patient-donor DPB1 mismatch could not be established. In addition to the in vitro data, retrospective studies indicated that DPB1 matching status can seriously affect transplantation outcome in a dual role; on one hand GVHD and on the other hand graft versus leukaemia (GVL) effect ${ }^{7,13,14}$.

Thus far the biological role of DPB1 in HSCT remains inconclusive because of contradictory results between the various patient studies. In case of allele mismatching for DPB1 and allele matching for HLA-A,-B,-C,-DRB1 and -DQB1 in unrelated HSCT, several studies have shown an increase in the risk of $\mathrm{GVHD}^{7,14-18}$ and/or a decrease in disease relapse $\mathrm{e}^{13,16,18,19}$. On the contrary, other studies have indicated that disparity for DPB1 decreases survival rate, without having an effect on $\mathrm{GVHD}^{20}$. Flomenberg et al. (2004) found no effect of DPB1 matching status on either transplantation related complications nor on disease relapse ${ }^{4}$. The contradictory results between the patient studies regarding DPB1 matching status, underline the fact that the interpretation of HLA-DPB1 diversity should be approached differently compared to the other transplantation antigens.

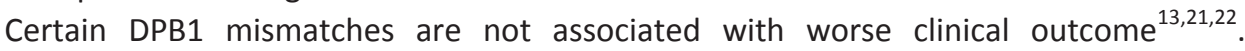
Permissiveness could be explained by differences at amino acid level which provoke no or a very low alloreactive response. As during positive thymic selection the $\mathrm{T}$ cell repertoire is generated with a sufficiently affinity for self-MHC, it has been proposed that the post-selection $\mathrm{T}$ cell is not able to recognize extensively mismatched $\mathrm{MHC}$ 
molecules $^{23}$. Nonetheless, it is still unclear specifically which amino acids or epitopes define the permissive and non-permissive DPB1 mismatch combinations. Several studies focused on DPB1 amino acid substitutions within the hypervariable regions of exon 2 to unravel the role on $\mathrm{T}$ and $\mathrm{B}$ cell mediated allorecognition and described that specific residues in the pockets of the peptide binding groove play a key role in HLA-DP functioning ${ }^{10,24-28}$. The group of Inoko evaluated allele groups based on the fourth, fifth and sixth hypervariable region in exon $2^{29}$, while other groups described also relevant roles for other positions within exon $2^{25,27}$. The individual amino acid variability within exon 2 has also been studied in disease association studies and showed e.g. a strong correlation between DPB1 amino acid position 69 in exon 2 and disease status ${ }^{30,31}$. In unrelated stem cell transplantation, however the findings on an association between patient outcome and exon 2 epitopes remain inconclusive ${ }^{14,17}$.

The group of Fleischhauer established, for the first time, an algorithm on the basis of reactivity of DPB1 allele specific alloreactive $T$ cells ${ }^{21,22}$. This algorithm indicates that depending on a specific T cell epitope (TCE) encoded in exon 2 of the DPB1 molecule, DPB1 alleles could be classified as permissive or non-permissive and clustered into functional allele groups. Interestingly, not for all allele groups shared amino acids in exon 2 between the alleles could be identified. Nevertheless, they have described an increase in mortality in transplant pairs with non-permissive DPB1 disparity ${ }^{21}$.

Other groups have defined immunogenic epitopes within the DPB1 molecule by assigning antibody specificity to the amino acid difference between transplant donor and recipient. These studies have described immunodominance for hypervariable regions $\mathrm{F}$ and $\mathrm{C}$ in exon $2^{32,33}$, however, approximately $20 \%$ of the cases with anti-DP reactivity could not be assigned to exon 2 polymorphism ${ }^{34}$. From these studies on DPB1 immunogenicity it can be emphasized that exon 2 polymorphism might not be sufficient in defining the permissive and non-permissive DPB1 allele combinations and that therefore the DPB1 polymorphism outside exon 2 should be considered.

$T$ cell binding is not restricted to the polymorphic groove of the HLA molecule since the CD4 co-receptor can also bind to the $\alpha 2$ and $\beta 2$ domain of the HLA class II molecule ${ }^{35,36}$. The interaction between the CD4 co-receptor and HLA class II has been shown to be affected by polymorphism in the $\beta 2$ domain of the HLA-DR molecule and the variation in CD4 binding capacities could be ascribed to polymorphism at residues 180, 181 and $187^{37}$. Furthermore, it has been shown that peptides of the alpha 3 and transmembrane domain of HLA class I can evoke an indirect alloreactive response despite limited polymorphism ${ }^{38}$. Considering the difficulties to classify the DPB1 alleles in functional groups these findings underline the importance of full length HLA-DP polymorphism.

In the present study, we hypothesized that polymorphism of the entire molecule, including polymorphic variability in different ethnic groups, is crucial to unravel immunogenicity. Previously, we defined in a pilot study with 16 samples, polymorphism in the coding regions outside exon $2^{39}$. In the present study, we used an RNA based full length sequencing approach to determine the entire DPB1 coding region of 
148 samples representing all frequent and available non-frequent DPB1 alleles from Caucasian, Black and Oriental origin. We analysed multiple DPB1 alleles with identical exon 2 sequences belonging to the same or to a different ethnic group in order to determine polymorphism in the coding regions beyond exon 2 .

\section{Material and methods}

\section{HLA-DPB1 panel of cells}

148 Epstein-Bar virus transformed B-cell lymphoblastoid International Histocompatibility Workshop cell lines (BLCLs) and peripheral blood mononuclear cell (PBMC) samples, were used to select all frequent $(>1 \%)$ and available infrequent $(<1 \%)$ HLA-DPB1 alleles. Of these 148 samples, 61 were from Caucasian origin, 46 from Black origin, 37 from Oriental origin and 1 from American Indian origin. Of three cell lines the ethnicity was unknown. The BLCLs were cultured in RPMI 1640 culture medium (Invitrogen, Bleiswijk, the Netherlands) supplemented with $15 \%$ heat inactivated Foetal Bovine Serum (Invitrogen, Bleiswijk, the Netherlands), $2 \mathrm{mM}$ L-glutamine and $1 \%$ Penicillin Streptomycin (Invitrogen, Bleiswijk, the Netherlands) in a $37^{\circ} \mathrm{C}, 5 \% \mathrm{CO}_{2}$ incubator. PBMCs were isolated from heparinised blood with lymphoprep separation medium (AXIS-SHIELD, Dundee, Scotland) by gradient centrifugation. Prior to RNA isolation, cells were washed with PBS (B.Braun, Melsungen, Germany).

\section{RNA isolation and RT-PCR}

Total RNA was isolated from approximately 10 million cells per BLCL or 10 million PBMCs using the RNeasy minikit (Qiagen, Hilden, Germany) according to manufacturer's protocol. cDNA synthesis was performed using $5 \mu \mathrm{g}$ of RNA with the Superscript III first-strand synthesis system for RT-PCR (Invitrogen, California, USA). The quality of the cDNA was verified by amplification of the housekeeping gene glyceraldehyde-3-phosphate dehydrogenase (GAPDH). HLA-DPB1 cDNA was amplified using 5'UTR and 3'UTR amplification primers (Table 2.1) which resulted in a $1146 \mathrm{bp}$ PCR product. The PCR was performed in a volume of $50 \mu \mathrm{l}$, with final concentrations of GeneAmp 1X PCR buffer II containing $100 \mathrm{mM}$ Tris- $\mathrm{HCl}, \mathrm{pH} 8.3$ and $500 \mathrm{mM} \mathrm{KCl}$ (Applied Biosystems, New Jersey, USA), 1.5 mM MgCl 2 (Applied Biosystems, New Jersey, USA), $150 \mu \mathrm{M}$ dNTP (Amersham Pharmacia, Buckinghamshire, USA) 30 pmol of each amplification primer (Sigma Genosys), 0.05 units/ $\mu$ l of AmpliTaq DNA Polymerase (Applied Biosystems, New Jersey, USA) and 2-5 $\mu$ l cDNA. The PCR program consisted of a denaturing step of $2 \mathrm{~min}$ at $96^{\circ} \mathrm{C}$, followed by 10 cycles of $10 \mathrm{sec}$ at $94^{\circ} \mathrm{C}$ and $60 \mathrm{sec}$ at $65^{\circ} \mathrm{C}$ and $30 \mathrm{cycles}$ of $10 \mathrm{sec}$ at $94^{\circ} \mathrm{C}, 50 \mathrm{sec}$ at $61^{\circ} \mathrm{C}$ and $30 \mathrm{sec}$ at $72^{\circ} \mathrm{C}$ and a final elongation step of $10 \mathrm{~min}$ at $72^{\circ} \mathrm{C}$. 


\section{Sequence based typing}

Amplification of DPB1 was monitored on a 1,5\% agarose gel containing Ethidium Bromide with a final concentration of $0,5 \mu \mathrm{g} / \mathrm{ml}$ prior to sequencing. The PCR product of DPB1 was purified using 10 units of Exonuclease (Exo) I and 1 unit of shrimp alkaline phosphatase (SAP) (USB Corporation, Ohio, USA), incubated at $37^{\circ} \mathrm{C}$ for $15 \mathrm{~min}$ to degrade remaining primers and nucleotides, followed by a $15 \mathrm{~min}$ incubation at $80^{\circ} \mathrm{C}$ to inactivate the ExOSAP. The sequence mixture for one reaction consisted of $1 \mu$ l BigDye Terminator mix (Applied Biosystems, Austin, USA), $1.5 \mu \mathrm{l}$ of BigDye Terminator sequencing buffer (Applied Biosystems, Warrington, UK), $0.5 \mu \mathrm{l}$ DPB1 sequencing primer, $1 \mu \mathrm{l}$ of the purified PCR product and $6 \mu \mathrm{l}$ water to a total volume of $10 \mu \mathrm{l}$. PCR products were sequenced in both directions with the amplification (Table 2.1) and allele-specific sequencing primers ${ }^{40,41}$. Allele-specific sequencing primers were located at the polymorphic positions $119,194,254,280,292,313-315$ and 341-343 in exon 2.The sequence reaction was performed for $1 \mathrm{~min}$ at $96^{\circ} \mathrm{C}$, followed by 25 cycles of $10 \mathrm{sec}$ at $96^{\circ} \mathrm{C}, 5 \mathrm{sec}$ at $50^{\circ} \mathrm{C}$ and $60^{\circ} \mathrm{C}$ for $4 \mathrm{~min}$. After purification by filtration, the sequence products were electrophoresed on the ABI 3730 DNA sequencer. SeqMan Pro from DNASTAR 8.0 was used to analyse and adjust the sequences. Subsequently, in MEGALIGN from DNASTAR 8.0 the sequences were aligned via Clustal $\mathrm{W}^{42}$.

Table 2.1 DPB1 specific amplification primers for full length amplification of DPB1 CDS.

\begin{tabular}{lll}
\hline Primer name & Sequence $\left(5^{\prime}-3^{\prime}\right)$ & Location \\
\hline DPB10071 & CCTTCTTTTCCTGACTGCAG & 5'UTR \\
DPB10072 & TGYTAACRAAACACAGCAAATGC & Exon 6 \\
\hline
\end{tabular}

CDS, coding sequence; UTR, untranslated region.

\section{Results}

\section{Polymorphism beyond exon 2}

The aim of this study was to determine polymorphism in the coding regions beyond exon 2 within as many as available DPB1 alleles from different ethnic origin. We hypothesize that these coding regions are relevant to unravel DPB1 immunogenicity. Using an RNA based sequencing approach, all frequent DPB1 alleles and available nonfrequent alleles were full length sequenced in multiple samples from either Black, Caucasian or Oriental origin. In total 148 samples representing 28 different DPB1 alleles were selected for studying their full length DPB1 coding sequences. Table 2.2 shows the nucleotide polymorphism of exons $1,3,4$ and 5 and Table 2.3 shows the amino acid polymorphism of exons 1-5. The HLA-DPB1*03:01 allele was used as reference allele as it shows the most similarities with the other alleles based on polymorphism outside exon 2. Our results showed that various DPB1 alleles have, in addition to the polymorphism in exon 2, polymorphic positions in exons 1, 3, 4 and/or 5 . Based on the 
polymorphism outside exon 2, one new allele was identified. The allele was named DPB1*135:01 (EMBL accession nr.: FR775798 and WHO nomenclature committee submission number HWS10014324) and was found identical to DPB1*05:01 in exon 2 sequence, but showed a non-synonymous substitution in exon 4 and a nucleotide deletion in exon 5. The name DPB1*135:01 has been officially assigned by the WHO Nomenclature Committee in September 2011. This follows the agreed policy that, subject to the conditions stated in the most recent Nomenclature Report (Marsh et al. 2010), names will be assigned to new sequences as they are identified. Lists of such new names will be published in the following WHO Nomenclature Report.

In addition we completed the CDS sequences of multiple alleles of which the full length coding sequences were unknown in the IMGT HLA database; DPB1*06:01, *10:01, *11:01, *16:01, *17:01, *18:01, *21:01,*26:01:02,*27:01,*39:01 and *131:01 (Submitted to EMBL and IMGT/HLA nomenclature committee). We stratified all studied alleles in clusters based on the nucleotide similarities of exons 3, 4 and 5 (Tables 2.2 and 2.3).

The first cluster of alleles was characterized by identical sequences with the reference allele DPB1*03:01 regarding exons 1, 3, 4 and 5. The second cluster of alleles showed a nucleotide deletion in exon 5 . The deletion in exon 5 at position 777 has no influence on the stop codon and therefore does not alter the conformation. One of these alleles within this cluster, DPB1*107:01, showed nucleotide polymorphism in the 5' untranslated region (UTR) and in exon 1, resulting in an amino acid substitution Thr to Met at position -14 (Table 2.3). The alleles DPB1*107:01 and DPB1*13:01 have identical exon 2 sequences, which was also the case for DPB1*135:01 and DPB1*05:01. A third cluster of alleles was defined based on exon 4 polymorphism. The DPB1 alleles 05:01, 104:01 and 19:01 showed a non-synonymous nucleotide substitution in exon 4 at position 700, which resulted in an amino acid change of Val to Met at codon 205. The exon 2 sequence of DPB1*104:01 was identical to DPB1*03:01. The alleles of the fourth cluster also showed a substitution in exon 4, namely at position 668 . This nucleotide substitution resulted in an amino acid conversion Arg to Gln at codon 194. In our study we identified this substitution also in DPB1*131:01. The sequence of exons 1,4 and 5 of this allele were previously not determined. This allele showed identical exon 2 sequences when compared to DPB1*17:01. A fifth cluster was defined based on synonymous and non-synonymous substitutions in exon 3 . These non-synonymous substitutions caused an amino acid conversion Lys to Arg and Ile to Thr at codons 96 and 170, respectively. DPB1*105:01 had identical exon 2 sequences to DPB1*04:02, whereas DPB1*106:01 showed no differences in exon 2 with DPB1*19:01. Finally, DPB1*15:01 and *18:01 were clustered together based on a non-synonymous substitution at position 731 in exon 4. This substitution resulted in an amino acid change lle to Thr at codon 215. DPB1*15:01 showed in addition a synonymous substitution in exon 3 at position 636. 
Table 2.2 Overview of HLA-DPB1 extended nucleotide polymorphism outside exon 2 .

\begin{tabular}{|c|c|c|c|c|c|c|c|c|c|c|c|c|c|c|c|c|c|}
\hline & $\begin{array}{l}\text { Number of } \\
\text { sequenced } \\
\text { alleles + } \\
\text { ethnicity }\end{array}$ & 5'UT & & on 1 & & & & & Exon & & & & & & Exon & & Exon 5 \\
\hline DPB1 & & 15 & 24 & 47 & 374 & 381 & 406 & 441 & 588 & 596 & 619 & 624 & 636 & 668 & 700 & 731 & 777 \\
\hline *03:01 & $5 C, 4 B, 20$ & $\mathrm{t}$ & $\mathrm{g}$ & $C$ & $A$ & c & c & $a$ & c & $\mathrm{T}$ & $C$ & c & c & $\mathrm{G}$ & G & $\mathrm{T}$ & $a$ \\
\hline *09:01 & 1un & - & - & - & - & - & - & - & - & - & - & - & - & - & - & - & - \\
\hline *06:01 & 1un & - & - & - & - & - & - & - & - & - & - & - & - & - & - & - & - \\
\hline *10:01 & $2 \mathrm{C}, \mathrm{OB}, \mathrm{OO}$ & - & - & - & - & - & - & - & - & - & - & - & - & - & - & - & - \\
\hline *14:01 & $4 C, 0 B, 00$ & - & - & - & - & - & - & - & - & - & - & - & - & - & - & - & - \\
\hline *16:01 & $1 \mathrm{C}, \mathrm{OB}, 0 \mathrm{O}$ & - & - & - & - & - & - & - & - & - & - & - & - & - & - & - & - \\
\hline *21:01 & $0 \mathrm{C}, \mathrm{OB}, 1 \mathrm{O}$ & - & - & - & - & - & - & - & - & - & - & - & - & - & - & - & - \\
\hline *107:01 & $0 \mathrm{C}, 0 \mathrm{~B}, 2 \mathrm{O}$ & C & $a$ & $T$ & - & - & - & - & - & - & - & - & - & - & - & - & $\#$ \\
\hline *13:01 & $0 \mathrm{C}, 1 \mathrm{~B}, 10$ & - & - & - & - & - & - & - & - & - & - & - & - & - & - & - & $\#$ \\
\hline *27:01 & $1 \mathrm{Al}$ & - & - & - & - & - & - & - & - & - & - & - & - & - & - & - & $\#$ \\
\hline *135:01 & 1un & - & - & - & - & - & - & - & - & - & - & - & - & - & - & - & $\#$ \\
\hline *11:01 & $1 \mathrm{C}, 1 \mathrm{~B}, 0 \mathrm{O}$ & - & - & - & - & - & - & - & - & - & - & - & - & - & - & - & \# \\
\hline *05:01 & $6 C, 3 B, 80$ & - & - & - & - & - & - & - & - & - & - & - & - & - & $A$ & - & - \\
\hline *104:01 & $0 \mathrm{C}, 2 \mathrm{~B}, 0 \mathrm{O}$ & - & - & - & - & - & - & - & - & - & - & - & - & - & A & - & - \\
\hline *19:01 & $\mathrm{OC}, \mathrm{OB}, 1 \mathrm{O}$ & - & - & - & - & - & - & - & - & - & - & - & - & - & $A$ & - & - \\
\hline *01:01 & $4 C, 12 B, 40$ & - & - & - & - & - & - & - & - & - & - & - & - & $A$ & - & - & - \\
\hline *131:01 & $\mathrm{OC}, 2 \mathrm{~B}, 0 \mathrm{O}$ & - & - & - & - & - & - & - & - & - & - & - & - & A & - & - & - \\
\hline *26:01 & $0 \mathrm{C}, 0 \mathrm{~B}, 2 \mathrm{O}$ & - & - & - & - & - & - & - & - & - & - & - & - & A & - & - & - \\
\hline *17:01 & $2 C, 2 B, 10$ & - & - & - & $\mathrm{G}$ & $\mathrm{t}$ & $\mathrm{t}$ & g & $\mathrm{t}$ & $\mathrm{C}$ & - & $\mathrm{t}$ & - & - & - & - & - \\
\hline *106:01 & $0 \mathrm{C}, 1 \mathrm{~B}, 0 \mathrm{O}$ & - & - & - & G & $\mathrm{t}$ & $\mathrm{t}$ & $\mathrm{g}$ & $\mathrm{t}$ & $\mathrm{C}$ & - & $\mathrm{t}$ & - & - & - & - & - \\
\hline$* 02: 01$ & $8 C, 6 B, 30$ & - & - & - & G & $\mathrm{t}$ & $\mathrm{t}$ & g & $\mathrm{t}$ & $\mathrm{C}$ & - & $\mathrm{t}$ & - & - & - & - & - \\
\hline *02:02 & $3 \mathrm{C}, 0 \mathrm{~B}, 5 \mathrm{O}$ & - & - & - & $\mathrm{G}$ & $\mathrm{t}$ & $\mathrm{t}$ & $\mathrm{g}$ & $\mathrm{t}$ & $\mathrm{C}$ & - & $\mathrm{t}$ & - & - & - & - & - \\
\hline *04:01 & $19 C, 3 B, 40$ & - & - & - & G & $\mathrm{t}$ & $\mathrm{t}$ & $\mathrm{g}$ & $\mathrm{t}$ & C & - & $\mathrm{t}$ & - & - & - & - & - \\
\hline *105:01 & $1 \mathrm{C}, 2 \mathrm{~B}, 0 \mathrm{O}$ & - & - & - & G & $\mathrm{t}$ & $\mathrm{t}$ & $\mathrm{g}$ & $\mathrm{t}$ & C & - & $\mathrm{t}$ & - & - & - & - & - \\
\hline *39:01 & $0 C, 1 B, 00$ & - & - & - & G & $\mathrm{t}$ & $\mathrm{t}$ & $\mathrm{g}$ & $\mathrm{t}$ & C & - & $\mathrm{t}$ & - & - & - & - & - \\
\hline *04:02 & $5 C, 4 B, 30$ & - & - & - & $\mathrm{G}$ & $\mathrm{t}$ & $\mathrm{t}$ & $\mathrm{g}$ & $\mathrm{t}$ & $\mathrm{C}$ & A & $\mathrm{t}$ & - & - & - & - & - \\
\hline *15:01 & $0 \mathrm{C}, 1 \mathrm{~B}, 0 \mathrm{O}$ & - & - & - & - & - & - & - & - & - & - & - & $\mathrm{t}$ & - & - & C & - \\
\hline *18:01 & $0 \mathrm{C}, 1 \mathrm{~B}, 0 \mathrm{O}$ & - & - & - & - & - & - & - & - & - & - & - & - & - & - & C & - \\
\hline
\end{tabular}

- Identity with the DPB1*03:01:01 allele, \# nucleotide deletion. C=Caucasian, B=Black, O=Oriental, $\mathrm{Al}=$ American Indian, $\mathrm{un}=$ ethnicity is unknown. ${ }^{\mathrm{a}}$ Synonymous substitutions or non-coding polymorphism is indicated in lower cases; non-synonymous substitutions in upper cases. Various samples from different ethnicities containing alleles with identical exon 2 polymorphism were sequenced multiple times (second column). The blocks show clusters of alleles based on similar nucleotide substitutions in coding region outside exon 2. The new allele is shown in bold. 
Table 2.3 Overview of the HLA-DPB1 extended amino acid polymorphism showing among others the six hypervariable regions in exon 2 . $^{\text {a }}$

\begin{tabular}{|c|c|c|c|c|c|c|c|c|c|c|c|c|c|c|}
\hline \multirow[b]{2}{*}{ DPB1 } & \multirow[t]{2}{*}{$\begin{array}{l}\text { Number of } \\
\text { sequenced } \\
\text { alleles + } \\
\text { ethnicity }\end{array}$} & \multicolumn{2}{|c|}{ Exon 1} & \multicolumn{4}{|c|}{ Exon 2} & \multirow[b]{2}{*}{$84-87$} & \multirow[b]{2}{*}{96} & \multicolumn{3}{|c|}{ Exon 3} & \multicolumn{2}{|c|}{ Exon 4} \\
\hline & & -14 & $8-11$ & $35-36$ & $655-57$ & $65-69$ & 76 & & & 170 & 178 & 194 & 205 & 215 \\
\hline *03:01 & $5 C, 4 B, 20$ & $T$ & VYQL & FV & DED & LLEEK & $\mathrm{V}$ & DEAV & $\mathrm{K}$ & 1 & L & $\mathbf{R}$ & V & 1 \\
\hline *09:01 & 1un & - & VHQL & - & - & ILEEE & - & - & - & - & - & - & - & - \\
\hline *06:01 & 1un & - & - & - & - & LLEEE & $\mathrm{M}$ & - & - & - & - & - & - & - \\
\hline *10:01 & $2 \mathrm{C}, \mathrm{OB}, 0 \mathrm{O}$ & - & VHQL & - & DEE & ILEEE & - & - & - & - & - & - & - & - \\
\hline *14:01 & $4 \mathrm{C}, 0 \mathrm{~B}, 0 \mathrm{O}$ & - & VHQL & - & - & - & - & - & - & - & - & - & - & - \\
\hline *16:01 & $1 \mathrm{C}, \mathrm{OB}, 0 \mathrm{O}$ & - & LFQG & - & DEE & ILEEE & $M$ & - & - & - & - & - & - & - \\
\hline *21:01 & $O C, 0 B, 10$ & - & - & LV & $\mathrm{EAE}$ & ILEEE & $M$ & - & - & - & - & - & - & - \\
\hline *107:01 & $0 \mathrm{C}, 0 \mathrm{~B}, 2 \mathrm{O}$ & $M$ & - & YA & $\mathrm{AAE}$ & ILEEE & 1 & - & - & - & - & - & - & - \\
\hline *13:01 & $0 \mathrm{C}, 1 \mathrm{~B}, 1 \mathrm{O}$ & - & - & YA & AAE & ILEEE & 1 & - & - & - & - & - & - & - \\
\hline$* 27: 01$ & $1 \mathrm{Al}$ & - & - & YA & AAE & ILEEK & $M$ & - & - & - & - & - & - & - \\
\hline$* 135: 01$ & 1un & - & LFQG & LV & EAE & ILEEK & $M$ & - & - & - & - & - & - & - \\
\hline$* 11: 01$ & $1 \mathrm{C}, 1 \mathrm{~B}, 0 \mathrm{O}$ & - & - & YA & AAE & LLEER & $M$ & - & - & - & - & - & - & - \\
\hline *05:01 & $6 C, 3 B, 80$ & - & LFQG & LV & EAE & ILEEK & $M$ & - & - & - & - & - & $M$ & - \\
\hline$* 104: 01$ & $0 \mathrm{C}, 2 \mathrm{~B}, 0 \mathrm{O}$ & - & - & - & - & - & - & - & - & - & - & - & $M$ & - \\
\hline *19:01 & OC, $0 \mathrm{~B}, 10$ & - & LFQG & - & $\mathrm{EAE}$ & ILEEE & 1 & - & - & - & - & - & $M$ & - \\
\hline *01:01 & $4 C, 12 B, 40$ & - & VYQG & YA & AAE & ILEEK & - & - & - & - & - & $\mathbf{Q}$ & - & - \\
\hline *131:01 & $0 \mathrm{C}, 2 \mathrm{~B}, 0 \mathrm{O}$ & - & VHQL & - & - & ILEEE & $\mathrm{M}$ & - & - & - & - & $\mathbf{Q}$ & - & - \\
\hline *26:01 & $\mathrm{OC}, 0 \mathrm{~B}, 2 \mathrm{O}$ & - & VYQL & YA & $\mathrm{AAE}$ & ILEEK & - & - & - & - & - & $\mathbf{Q}$ & - & - \\
\hline *17:01 & $2 C, 2 B, 10$ & - & VHQL & - & - & ILEEE & $M$ & - & $\mathbf{R}$ & $T$ & - & - & - & - \\
\hline$* 106: 01$ & $0 C, 1 B, 00$ & - & LFQG & - & $\mathrm{EAE}$ & ILEEE & 1 & - & $\mathbf{R}$ & $\mathbf{T}$ & - & - & - & - \\
\hline *02:01 & $8 C, 6 B, 30$ & - & LFQG & - & DEE & ILEEE & $M$ & GGPM & $\mathbf{R}$ & $\mathbf{T}$ & - & - & - & - \\
\hline *02:02 & $3 \mathrm{C}, 0 \mathrm{~B}, 5 \mathrm{O}$ & - & LFQG & LV & $\mathrm{EAE}$ & ILEEE & $M$ & GGPM & $\mathbf{R}$ & $T$ & - & - & - & - \\
\hline *04:01 & $19 \mathrm{C}, 3 \mathrm{~B}, 4 \mathrm{O}$ & - & LFQG & FA & $\mathrm{AAE}$ & ILEEK & $M$ & GGPM & $\mathbf{R}$ & $T$ & - & - & - & - \\
\hline$* 105: 01$ & $1 \mathrm{C}, 2 \mathrm{~B}, 0 \mathrm{O}$ & - & LFQG & - & DEE & ILEEK & $M$ & GGPM & $\mathbf{R}$ & $\mathbf{T}$ & - & - & - & - \\
\hline *39:01 & $0 \mathrm{C}, 1 \mathrm{~B}, 0 \mathrm{O}$ & - & LFQG & YA & AAE & ILEEK & $M$ & GGPM & $\mathbf{R}$ & $\mathbf{T}$ & - & - & - & - \\
\hline *04:02 & $5 C, 4 B, 30$ & - & LFQG & - & DEE & ILEEK & $M$ & GGPM & $\mathbf{R}$ & $\mathbf{T}$ & $M$ & - & - & - \\
\hline *15:01 & $0 C, 1 B, 00$ & - & VYQG & YA & AAE & LLEER & $M$ & VGPM & - & - & - & - & - & $T$ \\
\hline *18:01 & $0 \mathrm{C}, 1 \mathrm{~B}, 0 \mathrm{O}$ & - & VYQG & - & DEE & ILEEK & $M$ & VGPM & - & - & - & - & - & $\mathbf{T}$ \\
\hline
\end{tabular}

\section{Full length polymorphism and ethnicity}

Exons 1-5 were sequenced in various DPB1 alleles from Caucasian, Black or Oriental origin to study the influence of ethnic variability on the occurrence of polymorphism in exons 1, 3, 4 and 5 . The number of alleles sequenced from the different ethnicities is indicated in Tables 2.2 and 2.3. Data are suggesting a correlation of polymorphism in the coding regions beyond exon 2 with different ethnic groups.

A total of 18 samples, previously typed as DPB1*05:01 based on exon 2, were full length sequenced. From these eighteen samples one was identified as the new allele, 
DPB1*135:01. Within seven samples previously typed as the DPB1*17:01, two samples were identified as DPB1*131:01, based on substitutions in exons 3 and 4. Interestingly, these two samples were both from Black origin, confirming the identification of DPB1*131:01 in a Black individual ${ }^{43}$. In a previous study we identified more alleles based on polymorphism beyond exon 2 (DPB1*104:01-107:01) ${ }^{39}$. Twelve samples were previously typed as DPB1*03:01 and after full length sequencing two of these alleles were identified as the new counterpart DPB1*104:01 which were both from Black origin. Moreover, within fifteen samples previously typed as DPB1*04:02 based on exon 2, three samples were identified as it's new counterpart DPB1*105:01 after full length sequencing. Of these three samples, one was of Caucasian origin and two of Black origin. Only two samples were available which were previously typed as DPB1*19:01. The new counterpart DPB1*106:01 was found in one of these two samples which was of Black ethnicity. Finally, DPB1*13:01 was previously typed in four samples of which, after full length sequencing, two were identified as the new counterpart DPB1*107:01. Interestingly, these two samples were both from Oriental origin. With this data we focus on the occurrence of full length DPB1 polymorphism in various ethnic groups and conclude that specific polymorphism outside exon 2 might be associated with ethnicity.

\section{DPB1 polymorphism and CD4 co-receptor interaction}

Our data showed DPB1 polymorphism in the coding regions beyond exon 2, even in alleles that have identical exon 2 sequences. Various alleles showed multiple nonsynonymous polymorphic positions in exon 3 . Since exon 3 encodes for the $\beta 2$-chain of the DPB1 molecule it can be questioned which influence the amino acid changes have on $T$ cell interaction and functionality. With the use of the CD4 and DP structures, retained from the RCSB Protein Data Bank, we modelled our sequence alignment from the alleles DPB1*17:01 and the counterpart DPB1*131:01 (Figure 2.1) using the SWISPdbViewer $^{44}$. Although the contact residues in the $\beta 2$-chain for the CD4 co-receptor are still unknown, the composed model illustrates that the CD4 co-receptor possibly could interact with or near the region containing the polymorphic positions in the $\beta 2$-chain.

\section{Discussion}

We studied full length coding sequences in frequent and non-frequent DPB1 alleles from Black, Caucasian or Oriental ethnicity. DPB1 alleles identical in exon 2 were full length sequenced in multiple samples from the same or different ethnic groups. We identified polymorphism in exons $1,3,4$ and 5, in addition to the known exon 2 polymorphism. Exon 2 positions 84-87 (VGPM) in the alleles 15:01 and 18:01 correlate with position $215(T)$ in exon 4, however, no other correlations between polymorphism in exon 2 and the other coding regions could be defined. Interestingly, alleles that were 
identical in their exon 2 sequence showed polymorphism in the coding regions beyond exon 2. Previously, we described in a pilot study new alleles based on polymorphism beyond exon $2^{39}$. In the present study, we identified one new allele based on exon 4 polymorphism and a nucleotide deletion in exon 5 , and we confirmed and extended the sequences lacking in earlier described alleles. This provides us with new information about the occurrence of polymorphism in the coding regions outside exon 2 .

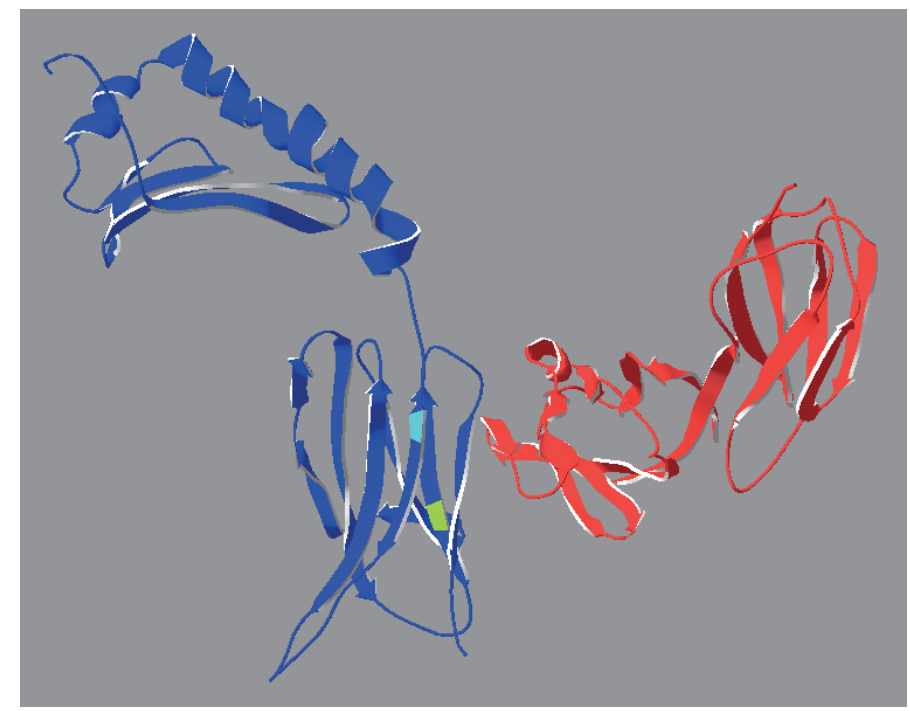

Figure 2.1 The structure of a DPB1-CD4 complex representing the polymorphic locations of DPB1*17:01 and DPB1*131:01 in an overlay picture. The exon 2 and 3 sequences of DPB*17:01 and DPB1*131:01 were modelled using the X-ray crystal structure HLA-DP2 (Protein Data Bank (PDB):3lqz). The X-ray crystal structure of murine I-A/human CD4 (Protein Data Bank (PDB):1JL4) was used as model for the external part of the CD4 co-receptor. Missing residues in the DP-TCR complex were reconstructed by homology modelling using SWISS-PdbViewer 4.0.1 $1^{42}$. Both variant structures were energy minimized and underwent $10 \mathrm{ps}$ molecular dynamics (MD) simulations with a distant-dependent dielectric constant. All parameters were set to default for the minimization and MD simulations. The dark blue structure represents the DPB1 molecule. Within this structure the blue highlight represent the $K(D P B * 131: 01)$ to $R$ (DPB1*17:01) substitution in exon 3 and the green highlight the I (DPB*131:01) to $\mathrm{T}(\mathrm{DPB} 1 * 17: 01)$ substitution in exon 3 . The red structure represents the external part of the CD4 co-receptor.

Regarding the ethnic origin of the different alleles, DPB1*107:01 was identified in two cell lines, both of Oriental origin. Nevertheless, since the original exon 2 identical allele, DPB1*13:01, has previously been identified in the Oriental population with a high frequency ${ }^{45}$, the finding of the DPB1*107:01 allele in samples from Oriental origin was not surprising. Interestingly, the new variant of the DPB1*17:01, DPB1*131:01, was identified in two samples which were both of Black origin. This was also the case for 
DPB1*104:01, which is a new variant of DPB1*03:01. The fact that several new allele variants were identified in samples belonging to a particular ethnic group suggests that the occurrence of these new alleles might be linked to a specific ethnicity.

Previous studies have shown inconsistent results regarding the role of HLA-DPB1 mismatching in stem cell transplantation ${ }^{7,13-20}$ and have proposed the concept that certain DPB1 mismatches are permissive ${ }^{13,21,22}$. Some groups have described specific amino acid positions in exon 2 provoking an alloreactive response ${ }^{24-27}$. However, in the attempt to establish immunogenic groups based on T cell reactivity or serology, a direct correlation to exon 2 polymorphism could not be established for all alleles ${ }^{22,34}$. This suggests that allorecognition is not only defined by epitopes encoded by exon 2 . Since the $T$ cell receptor can cover a larger area of the molecule then only the peptide binding groove ${ }^{35,36,46}$ and amino acid differences encoded outside the peptide binding groove in HLA class I and II can give rise to changes in the conformation of the molecule $e^{37,47}$, polymorphism beyond exon 2 may be relevant to unravel the role of DPB1 in HSCT. The role of HLA-DPA1 was not elucidated in this study partially because DPA1 is known to be in strong linkage disequilibrium with DPB1 ${ }^{45}$. HLA-DPA1 seems to influence T cell recognition as the CD4 co-receptor also binds to the alpha chain of the DP molecule ${ }^{36}$. Therefore, it would be interesting to also study full length polymorphism of the alpha chain.

In exon 1, encoding the leader peptide, we identified a single polymorphic position which resulted in an amino acid change from Thr to Met. The leader peptide has been proposed to play an important role in targeting the pro-peptide to the endoplasmatic reticulum and assisting in folding and stabilization of the pro-peptide ${ }^{48}$. As the polymorphic position in exon 1 consists of a change from a hydrophilic amino acid with polar side chains to a hydrophobic amino acid, it could have an effect on the functional properties of the leader peptide in assisting the core peptide.

The $\beta 2$-chain of the HLA class II molecule possesses binding residues for the CD4 coreceptor $^{35,46,49}$. Polymorphism in the $\alpha 3$-domain of HLA class I has been shown to influence HLA class I-restricted T cell responses ${ }^{50-52}$, including positive and negative selection as the $\alpha 3$-domain in the thymus interacts with the T-cell accessory molecule (CDS) CD8, which is important in the selection of $T$ cells ${ }^{53}$. The DPB1 amino acid polymorphisms we defined in exon 3 are a change of Lys to Arg at position 96, lle to Thr at position 170 and Leu to Met at position 178. Because Lys and Arg both have positively charged side chains, this amino acid change was not expected to influence the conformation of the molecule. Also the Leu to Met change might not alter the conformation, since both have hydrophobic side chains. In contrast, the substitution of Ile to Thr at position 170 could affect conformational changes as Thr, in contrast to lle, is an uncharged hydrophilic amino acid and capable of forming hydrogen bonds. Although the contact residues for CD4 are still unknown, polymorphism in the $\beta 2$-chain of the HLA-DRB gene has been shown to influence CD4 co-receptor interaction ${ }^{37}$. Therefore, the amino acid change at position 170 in exon 3 could have an effect on $\mathrm{CD} 4+\mathrm{T}$ cell activation status. 
The polymorphism we defined in exon 4, encoding the transmembrane region, consists of a change from Arg to GIn at position 194, a change from Val to Met at position 205 and a change from lle to Thr at position 215. The impact of polymorphism in the transmembrane domain of HLA molecules remains to be defined. However, a frameshift mutation in the DPB1 exon coding for the transmembrane region has been described to change the hydropathicity pattern of the transmembrane domain which was responsible for a change in phenotype ${ }^{54}$. Furthermore, mutations in the transmembrane region of tapasin have been found to influence the functional properties of the molecule ${ }^{55}$. As the polymorphism we defined in exon 4 at position 194 is a change from a positive charged to a negative charged amino acid this polymorphism may lead to conformational or expression differences of the surface protein. Such an effect on the conformation of the protein would not be expected from the change of Val to Met at position 205 as they both possess hydrophobic side chains. The substitution of lle to Thr at position 215 could affect conformational changes because, as mentioned earlier Thr, in contrast to Ile, is an uncharged hydrophilic amino acid and capable of forming hydrogen bonds. Studies have shown that HLA class II expression level is an important factor for the development of severe malignancies, HLA class II down regulation is generally associated with a more severe disease state $^{56-59}$. As the amino acid change in the transmembrane domain could have an important influence on the expression level it is crucial to study the functionality of this polymorphism more profoundly.

As previously described, it is not possible to directly correlate exon 2 polymorphism to $\mathrm{T}$ cell reactivity and serology which strongly suggests a role for amino acid positions outside the antigen recognition side. Until now there is very little known about the influence of the amino acid positions outside the antigen recognition site, especially the effects on T cell activation level. Since the interpretation of DPB1 diversity is complex, full length polymorphism will provide new insights in the classification of DPB1 polymorphism and more importantly will add new perspectives to the concept of permissiveness in transplantation.

\section{Acknowledgements}

We thank Veerle Crijns and Christel Meertens for their contribution in registering the new identified coding sequences to the EMBL and IMGT HLA databases. 


\section{References}

1. Welniak LA, Blazar BR, Murphy WJ. Immunobiology of allogeneic hematopoietic stem cell transplantation. Annu Rev Immunol 2007:25:139-70.

2. Keever CA, Leong N, Cunningham I, Copelan EA, Avalos BR, Klein J, Kapoor N, Adams PW, Orosz CG, Tutschka PJ, et al. HLA-B44-directed cytotoxic T cells associated with acute graft-versus-host disease following unrelated bone marrow transplantation. Bone Marrow Transplant 1994: 14:137-45.

3. Petersdorf EW, Anasetti C, Martin PJ, Gooley T, Radich J, Malkki M, Woolfrey A, Smith A, Mickelson E, Hansen JA. Limits of HLA mismatching in unrelated hematopoietic cell transplantation. Blood 2004: 104: 2976-80.

4. Flomenberg N, Baxter-Lowe LA, Confer D, Fernandez-Vina M, Filipovich A, Horowitz M, Hurley C, Kollman C, Anasetti C, Noreen H, Begovich A, Hildebrand W, Petersdorf E, Schmeckpeper B, Setterholm M, Trachtenberg E, Williams T, Yunis E, Weisdorf D. Impact of HLA class I and class II high-resolution matching on outcomes of unrelated donor bone marrow transplantation: HLA-C mismatching is associated with a strong adverse effect on transplantation outcome. Blood 2004:104:1923-30.

5. Lee SJ, Klein J, Haagenson M, Baxter-Lowe LA, Confer DL, Eapen M, Fernandez-Vina M, Flomenberg N, Horowitz M, Hurley CK, Noreen H, Oudshoorn M, Petersdorf E, Setterholm M, Spellman S, Weisdorf D, Williams TM, Anasetti C. High-resolution donor-recipient HLA matching contributes to the success of unrelated donor marrow transplantation. Blood 2007:110:4576-83.

6. Petersdorf EW, Smith AG, Mickelson EM, Longton GM, Anasetti C, Choo SY, Martin PJ, Hansen JA. The role of HLA-DPB1 disparity in the development of acute graft-versus-host disease following unrelated donor marrow transplantation. Blood 1993:81: 1923-32.

7. Petersdorf EW, Gooley T, Malkki M, Anasetti C, Martin P, Woolfrey A, Smith A, Mickelson E, Hansen JA. The biological significance of HLA-DP gene variation in haematopoietic cell transplantation. Brit J Haematol 2001:112:988-94.

8. Shaw S, Johnson AH, Shearer GM. Evidence for a new segregant series of B cell antigens that are encoded in the HLA-D region and that stimulate secondary allogenic proliferative and cytotoxic responses. J Exp Med 1980:152:565-80.

9. Termijtelen A, Khan PM, Shaw S, Rood van JJ. Mapping SB in relation to HLA and GL01 using cells from first-cousin marriage offspring. Immunogenetics 1983:18:503-12.

10. Marshall WH, Drover S, Codner D, Gamberg J, Copp MD, Liu HW, Deng LT, Younghusband HB. HLA-DP epitope typing using monoclonal antibodies. Hum Immunol 1998:59:189-97.

11. Farrell C, Honeyman M, Hoadley C. An analysis of the effect of HLA-DP in the mixed lymphocyte reaction. J Immunogenet 1988:15:243-50.

12. Olerup O, Moller E, Persson U. HLA-DP incompatibilities induce significant proliferation in primary mixed lymphocyte cultures in HLA-A, -B, -DR and -DQ compatible individuals: implications for allogeneic bone marrow transplantation. Tissue Antigens 1990:36:194-202.

13. Kawase T, Matsuo K, Kashiwase K, Inoko H, Saji H, Ogawa S, Kato S, Sasazuki T, Kodera Y, Morishima Y; Japan Marrow Donor Program. HLA mismatch combinations associated with decreased risk of relapse: implications for the molecular mechanism. Blood 2009:113:2851-8.

14. Ludajic K, Balavarca Y, Bickeböller H, Pohlreich D, Kouba M, Dobrovolna M, Vrana M, Rosenmayr A, Fischer GF, Fae I, Kalhs P, Greinix HT. Impact of HLA-DPB1 allelic and single amino acid mismatches on HSCT. Br J Haematol 2008:142:436-43.

15. Varney MD, Lester S, McCluskey J, Gao X, Tait BD. Matching for HLA DPA1 and DPB1 alleles in unrelated bone marrow transplantation. Hum Immunol 1999:60:532-8.

16. Shaw BE, Gooley TA, Malkki M, Madrigal JA, Begovich AB, Horowitz MM, Gratwohl A, Ringdén O, Marsh SG, Petersdorf EW. The importance of HLA-DPB1 in unrelated donor hematopoietic cell transplantation. Blood 2007:110:4560-6.

17. Loiseau P, Espérou H, Busson M, Sghiri R, Tamouza R, Hilarius M, Raffoux C, Devergie A, Ribaud P, Socié G, Gluckman E, Charron D. DPB1 disparities contribute to severe GVHD and reduced patient survival after unrelated donor bone marrow transplantation. Bone Marrow Transplant 2002:30: 497-502.

18. Shaw BE, Potter MN, Mayor NP, Pay AL, Smith C, Goldman JM, Prentice HG, Marsh SG, Madrigal JA. The degree of matching at HLA-DPB1 predicts for acute graft-versus-host disease and disease relapse following haematopoietic stem cell transplantation. Bone Marrow Transplant 2003:31:1001-8. 
19. Shaw BE, Marsh SG, Mayor NP, Russell NH, Madrigal JA. HLA-DPB1 matching status has significant implications for recipients of unrelated donor stem cell transplants. Blood 2006:107:1220-6.

20. Shaw BE, Mayor NP, Russell NH, Apperley JF, Clark RE, Cornish J, Darbyshire P, Ethell ME, Goldman JM, Little AM, Mackinnon S, Marks DI, Pagliuca A, Thomson K, Marsh SG, Madrigal JA. Diverging effects of HLA-DPB1 matching status on outcome following unrelated donor transplantation depending on disease stage and the degree of matching for other HLA alleles. Leukemia 2010:24:58-65.

21. Crocchiolo R, Zino E, Vago L, Oneto R, Bruno B, Pollichieni S, Sacchi N, Sormani MP, Marcon J, Lamparelli T, Fanin R, Garbarino L, Miotti V, Bandini G, Bosi A, Ciceri F, Bacigalupo A, Fleischhauer K; Gruppo Italiano Trapianto di Midollo Osseo, Cellule Staminale Ematopoietiche (CSE) e Terapia Cellulare; Italian Bone Marrow Donor Registry. Nonpermissive HLA-DPB1 disparity is a significant independent risk factor for mortality after unrelated hematopoietic stem cell transplantation. Blood 2009:114: 1437-44.

22. Zino E, Frumento G, Marktel S, Sormani MP, Ficara F, Di Terlizzi S, Parodi AM, Sergeant R, Martinetti M, Bontadini A, Bonifazi F, Lisini D, Mazzi B, Rossini S, Servida P, Ciceri F, Bonini C, Lanino E, Bandini G, Locatelli F, Apperley J, Bacigalupo A, Ferrara GB, Bordignon C, Fleischhauer K. A T-cell epitope encoded by a subset of HLA-DPB1 alleles determines nonpermissive mismatches for hematologic stem cell transplantation. Blood 2004:103: 1417-24.

23. Heemskerk MB, Roelen DL, Dankers MK, van Rood JJ, Claas FH, Doxiadis II, Oudshoorn M. Allogeneic $\mathrm{MHC}$ class I molecules with numerous sequence differences do not elicit a CTL response. Hum Immunol 2005:66:969-76.

24. Cesbron A, Moreau P, Milpied N, Harousseau JL, Muller JY, Bignon JD. Crucial role of the third and fourth hypervariable regions of HLA-DPB1 allelic sequences in the mixed lymphocyte reaction. Hum Immunol 1992:33:202-7.

25. Cesbron A, Moreau P, Cheneau ML, Cury S, Milpied N, Muller JY, Harousseau JL, Bignon JD. Crucial role of the third and fourth hypervariable regions of HLA-DPB1 allelic sequences in primary mixedlymphocyte reaction: application in allogeneic bone marrow transplantation. Transplant Proc 1993:25:1232-3.

26. Díaz G, Catálfamo M, Coiras MT, Alvarez AM, Jaraquemada D, Nombela C, Sánchez-Pérez M, Arroyo J. HLA-DP beta residue 69 plays a crucial role in allorecognition. Tissue Antigens 1998:52:27-36.

27. Díaz G, Amicosante M, Jaraquemada D, Butler RH, Guillén MV, Sánchez M, Nombela C, Arroyo J. Functional analysis of HLA-DP polymorphism: a crucial role for DPbeta residues 9, 11, 35, 55, 56, 69 and 84-87 in T cell allorecognition and peptide binding. Int Immunol 2003:15:565-76.

28. Nicholson I, Varney M, Kanaan C, Grigg A, Szer J, Tiedemann K, Tait BD. Alloresponses to HLA-DP detected in the primary MLR: correlation with a single amino acid difference. Hum Immunol 1997: 55:163-9.

29. Naruse TK, Nose Y, Kagiya M, Liao G, Nabeya N, Kimura M, Isshiki G, Inoko H. Cloned primed lymphocyte test cells recognize the fourth, fifth, and sixth hypervariable regions at amino acid positions 65-87 of the DPB1 molecule. Hum Immunol 1995: 42:123-30.

30. Richeldi L, Sorrentino R, Saltini C. HLA-DPB1 glutamate 69: a genetic marker of beryllium disease. Science 1993:262:242-4.

31. Rossman MD, Stubbs J, Lee CW, Argyris E, Magira E, Monos D. Human leukocyte antigen class II amino acid epitopes. Am J Resp Crit Care Med 2002:165:788-94.

32. Duquesnoy RJ, Awadalla Y, Lomago J, Jelinek L, Howe J, Zern D, Hunter B, Martell J, Girnita A, Zeevi A. Retransplant candidates have donor-specific antibodies that react with structurally defined HLA-DR, DQ, DP epitopes. Transpl Immunol 2008:18:352-60.

33. Cano P, Fernandez-Vina M. Two sequence dimorphisms of DPB1 define the immunodominant serologic epitopes of HLA-DP. Hum Immunol 2009:70:836-43.

34. Billen EV, Christiaans MH, Doxiadis, II, Voorter CE, van den Berg-Loonen EM. HLA-DP antibodies before and after renal transplantation. Tissue Antigens 2010:75:278-85.

35. Cammarota G, Scheirle A, Takacs B, Doran DM, Knorr R, Bannwarth W, Guardiola J, Sinigaglia F. Identification of a CD4 binding site on the beta 2 domain of HLA-DR molecules. Nature 1992:356: 799-801.

36. Gaubin M, Houlgatte R, Dettin M, Scarinci C, Martin M, Guardiola J, Di Bello C, Piatier-Tonneau D. Definition of the alpha 2 region of HLA-DR molecules involved in CD4 binding. Hum Immunol 1999:60:273-81. 
37. Fleury S, Thibodeau J, Croteau G, Labrecque N, Aronson HE, Cantin C, Long EO, Sékaly RP. HLA-DR polymorphism affects the interaction with CD4. J Exp Med 1995:182:733-41.

38. Hanvesakul R, Maillere B, Briggs D, Baker R, Larche M, Ball S. Indirect recognition of T-cell epitopes derived from the alpha 3 and transmembrane domain of HLA-A2. Am J Transplant 2007:7:1148-57.

39. Reinders J, Rozemuller EH, Gent van R, Arts-Hilkes YHA, Tweel van den JG, Tilanus MGJ. Extended HLADPB1 polymorphism: an RNA approach for HLA-DPB1 typing. Immunogenetics 2005:57:790-4.

40. Versluis LF, Rozemuller EH, Duran K, Tilanus MGJ. Ambiguous DPB1 allele combinations resolved by direct sequencing of selectively amplified alleles. Tissue Antigens 1995:46:345-9.

41. Voorter C, Berg van den-Loonen E. Sequence-based typing for HLA-DPB1: Strategy for ALF express. In: Hansen JA, ed. Immunobiology of the human MHC: Proceedings of the 13th International Histocompatability Workshop and Conference. Volume I. 2006:376-9.

42. Thompson JD, Higgins DG, Gibson TJ. CLUSTAL W: improving the sensitivity of progressive multiple sequence alignment through sequence weighting, position-specific gap penalties and weight matrix choice. Nucleic Acids Res 1994:22:4673-80.

43. Robinson J, Mistry K, McWilliam H, Lopez R, Parham P, Marsh SG. The IMGT/HLA database. Nucleic Acids Res 2011:39 Suppl 1:D1171-6.

44. Guex N, Peitsch MC. SWISS-MODEL and the Swiss-PdbViewer: an environment for comparative protein modeling. Electrophoresis 1997:18:2714-23.

45. Begovich AB, Moonsamy PV, Mack SJ, Barcellos LF, Steiner LL, Grams S, Suraj-Baker V, Hollenbach J, Trachtenberg E, Louie L, Zimmerman P, Hill AV, Stoneking M, Sasazuki T, Konenkov VI, Sartakova ML, Titanji VP, Rickards O, Klitz W. Genetic variability and linkage disequilibrium within the HLA-DP region: analysis of 15 different populations. Tissue Antigens 2001:57:424-39.

46. Konig R, Huang LY, Germain RN. MHC class II interaction with CD4 mediated by a region analogous to the MHC class I binding site for CD8. Nature 1992:356:796-8.

47. Balas A, Santos S, Aviles MJ, García-Sánchez F, Lillo R, Alvarez A, Villar-Guimerans LM, Vicario JL. Elongation of the cytoplasmic domain, due to a point deletion at exon 7, results in an HLA-C null allele, $\mathrm{CW}^{*} 0409 \mathrm{~N}$. Tissue Antigens 2002:59:95-100.

48. Oman TJ, van der Donk WA. Follow the leader: the use of leader peptides to guide natural product biosynthesis. Nat Chem Biol 2010:6:9-18.

49. Wang JH, Meijers R, Xiong Y, Liu JH, Sakihama T, Zhang R, Joachimiak A, Reinherz EL. Crystal structure of the human CD4 N-terminal two-domain fragment complexed to a class II MHC molecule. Proc Natl Acad Sci U S A 2001:98:10799-804.

50. Potter TA, Rajan TV, Dick RF, 2nd, Bluestone JA. Substitution at residue 227 of H-2 class I molecules abrogates recognition by CD8-dependent, but not CD8-independent, cytotoxic T lymphocytes. Nature 1989:337:73-5.

51. Aldrich CJ, Lowen LC, Mann D, Nishimura M, Hood L, Stroynowski I, Forman J. The Q7 alpha 3 domain alters T cell recognition of class I antigens. J Immunol 1991:146:3082-90.

52. Purbhoo MA, Boulter JM, Price DA, Vuidepot AL, Hourigan CS, Dunbar PR, Olson K, Dawson SJ, Phillips $\mathrm{RE}$, Jakobsen BK, Bell JI, Sewell AK. The human CD8 coreceptor effects cytotoxic T cell activation and antigen sensitivity primarily by mediating complete phosphorylation of the T cell receptor zeta chain. $J$ Biol Chem 2001:276:32786-92.

53. Aldrich CJ, Hammer RE, Jones-Youngblood S, Koszinowski U, Hood L, Stroynowski I, Forman J. Negative and positive selection of antigen-specific cytotoxic $\mathrm{T}$ lymphocytes affected by the alpha 3 domain of MHC I molecules. Nature 1991:352:718-21.

54. Arroyo J, Diez-Orejas R, Alvarez AM, Shaw S, Sanchez-Perez M. Molecular analysis of an HLA-DP mutant cell line selected for its resistance to killing by HLA-DPw2-specific T-cell clones. Immunogenetics 1994:39:40-7.

55. Petersen JL, Hickman-Miller HD, Mcllhaney MM, Vargas SE, Purcell AW, Hildebrand WH, Solheim JC. A charged amino acid residue in the transmembrane/cytoplasmic region of tapasin influences MHC class I assembly and maturation. J Immunol 2005:174:962-9.

56. Shi B, Vinyals A, Alia P, Broceño C, Chen F, Adrover M, Gelpi C, Price JE, Fabra A. Differential expression of $\mathrm{MHC}$ class II molecules in highly metastatic breast cancer cells is mediated by the regulation of the CIITA transcription Implication of CIITA in tumor and metastasis development. Int J Biochem Cell Biol 2006:38:544-62. 
57. Diepstra A, van Imhoff GW, Karim-Kos HE, van den Berg A, te Meerman GJ, Niens M, Nolte IM, Bastiaannet E, Schaapveld M, Vellenga E, Poppema S. HLA class II expression by Hodgkin ReedSternberg cells is an independent prognostic factor in classical Hodgkin's lymphoma. J Clin Oncol 2007:25:3101-8.

58. Meissner M, Konig V, Hrgovic I, Valesky E, Kaufmann R. Human leucocyte antigen class I and class II antigen expression in malignant fibrous histiocytoma, fibrosarcoma and dermatofibrosarcoma protuberans is significantly downregulated. J Eur Acad Dermatol Venereol 2010:24:1326-32.

59. O'Brien TR, Kohaar I, Pfeiffer RM, Maeder D, Yeager M, Schadt EE, Prokunina-Olsson L. Risk alleles for chronic hepatitis $B$ are associated with decreased mRNA expression of HLA-DPA1 and HLA-DPB1 in normal human liver. Genes Immun 2011:12:428-33. 



\section{Chapter 3}

\section{Effects of transmembrane region variability on cell surface expression and allorecognition of HLA-DP3}

Pietro Crivello*, Nina Lauterbach*, Laura Zito, Federico Sizzano, Cristina Toffalori, Jessica Marcon, Laura Curci, Arend Mulder, Lotte Wieten, Elisabetta Zino, Christien E.M. Voorter, Marcel G.J. Tilanus, Katharina Fleischhauer

Hum Immunol. 2013;74:970-977

*Both authors contributed equally 


\section{Abstract}

The functional relevance of polymorphisms outside the peptide binding groove of HLA molecules is poorly understood. Here we have addressed this issue by studying HLA-DP3, a common antigen relevant for functional matching algorithms of unrelated hematopoietic stem cell transplantation (HSCT) encoded by two transmembrane (TM) region variants, DPB1*03:01 and DPB1*104:01. The two HLA-DP3 variants were found at a overall allelic frequency of $10.4 \%$ in 201 volunteer stem cell donors, at a ratio of 4.2:1. No significant differences were observed in cell surface expression levels of the two variants on $B$ lymphoblastoid cell lines (BLCL), primary B cells or monocytes. Three different alloreactive $T$ cell lines or clones showed similar levels of activation marker CD107a and/or CD137 upregulation in response to HLA-DP3 encoded by DPB1*03:01 and DPB1*104:01, either endogenously on BLCL or after lentiveral-vector mediated transfer into the same cellular background. These data provide, for the first time, direct evidence for a limited functional role of a TM region polymorphism on expression and allorecognition of HLA-DP3 and are compatible with the notion that the two variants can be considered as a single functional entity for unrelated stem cell donor selection. 


\section{Introduction}

It is well established that the functionally most important part of the HLA molecule, in terms of antigen presentation and $\mathrm{T}$ cell recognition, is the peptide antigen binding groove, which is encoded by polymorphic exons 2 and 3 for HLA class I and exon 2 for HLA class $\|^{1,2}$. In line with this notion, numerous studies have found an association between the clinical outcome of volunteer unrelated donor (VUD)-hematopoietic stem cell transplantation (HSCT) and disparity for mismatches inside the antigen binding groove $^{3-6}$. Based on these findings, the internationally accepted definitions of histocompatibility typing terms limit the requirements for high resolution typing in VUD searches for HSCT to expressed alleles that encode the same protein sequence for the antigen binding groove ${ }^{7}$. As a consequence, for the majority of newly reported HLA alleles, the outside-the-groove sequence is unknown. For instance, nucleotide sequences beyond exon 2 are available only for 53/155 of the known HLA-DPB1 alleles to date (www.ebi.ac.uk/imgt/hla) ${ }^{8-10}$. Likewise, limited data are available regarding the functional or clinical impact of outside-the-groove variability. It has been shown that some of these polymorphisms can influence HLA surface expression by transcriptional regulation, alternative splicing or structural changes of the molecule ${ }^{11-13}$, while others did not change the repertoire of bound peptides ${ }^{14}$. From the clinical side, a polymorphism in exon 3 of DRB1*14:01/14:54 was shown not to have a significant impact on the outcome of unrelated VUD-HSCT ${ }^{15,16}$. None of the to date available studies have directly addressed the effects of outside-the-groove polymorphisms on T cell alloreactivity, the most relevant factor for graft versus host disease (GvHD), graft versus tumor activity and engraftment after allogeneic HSCT.

Here we have addressed this question for HLA-DP3, an antigen present with a

phenotypic frequency of about $20 \%$ in the Caucasian population ${ }^{17,18}$, which has been shown to be relevant in functional matching algorithms associated with mortality, GVHD and oncohematologic disease relapse after VUD-HSCT ${ }^{19-21}$. The HLA-DP3 betachain is encoded by two variants, DPB1*03:01 and DPB1*104:01, differing only for an amino acid substitution from valine to methionine at position 205 of the transmembrane (TM) region ${ }^{8,9}$. We set out to determine the relative frequency of the two variants and to better understand their functional implication in cell surface antigen expression and $T$ cell alloreactivity.

\section{Materials and methods}

\section{HLA-DPB1 typing}

Genomic high resolution HLA-DPB1 typing was performed by PCR-Sequence Specific

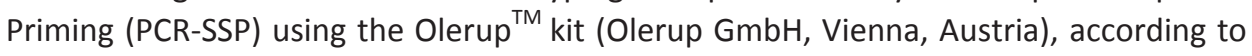
the manufacturer's recommendations. 


\section{Study population}

HLA-DPB1 allele frequencies were determined from 201 adult volunteer unrelated donors (VUD), mostly from Italian, German and American Registries, each selected for a different onco-hematologic patient, mainly of Caucasian origin, referring to the San Raffaele Scientific Institute in Milan for a stem cell donor search under institutionally approved protocols.

\section{B lymphoblastoid cell lines}

HLA-typed Epstein-Barr Virus transformed B lymphoblastoid cell lines (BLCL) were established according to standard protocols or purchased from the European Collection of Animal Cell Cultures (ECACC).

\section{Monoclonal antibodies}

The following monoclonal antibodies (mAb) were used: L243 (unconjugated anti-HLADR, Biolegend, Uithoorn, The Netherlands; or phycoerythrin (PE)-conjugated, anti-HLADR, Becton Dickinson (BD), Milan, Italy); B7/21 (unconjugated anti-HLA-DP, kindly provided by Sir Walter Bodmer, London, UK; or PE-conjugated anti-HLA-DP, Abcam, Cambridge, UK); TL-3B6 (unconjugated anti-HLA-DP-DEAV ${ }_{(84-87),}$ locally produced); W6/32 (unconjugated anti-HLA class I, Biolegend); ME20.4 (-allophycocyanin (APC)conjugated anti-nerve growth factor receptor (NGFR), Miltenyi Biotec Bergisch Gladbach, Germany); SK7 (conjugated anti-CD3-PE-Cy7, BD); MфP9 (conjugated antiCD14-fluorescein isothiocyanate (FITC), BD); HIB19 (conjugated anti-CD19-APC, BD); RPA-T4 (conjugated anti-CD4-APC, BD); 4B4-1 (conjugated anti-CD137-PE, BD); H4A3 (conjugated anti-CD107a-FITC, BD).

\section{Isolation of alloreactive T cell effectors}

T cells alloreactive to HLA-DP3 encoded by DPB1*03:01 were obtained by classical 1-way Mixed Lymphocyte Reactions (MLRs) between responder (R) and stimulator (S) peripheral blood mononuclear cells (PBMC) from VUD pairs matched for 8-10/10 of the HLA-A, -B, -C, -DRB1 and -DQB1 alleles. Briefly, R-PBMC were stimulated twice with irradiated S-PBMC at a $1: 1$ ratio in the presence of $150 \mathrm{UI} / \mathrm{ml}$ interleukin-2 (IL-2; Novartis, Varese, Italy). Alloreactive effector cells were maintained before (M3-VR/FV-3) or after (C2-DK/DK-3 and C11-DK/MN-3) limiting dilution cloning in the

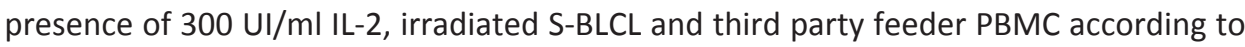
previously reported methods ${ }^{22}$.

\section{T cell activation marker upregulation assays}

Functional analysis of alloreactive effector $T$ cells was performed by flowcytometric quantification of activation markers CD137 or CD107a ${ }^{23,24}$. For CD137 upregulation, 
T cells were incubated with target $B L C L$ at a 1.5:1 ratio for 24 hours and stained with appropriately labeled anti-CD4 and anti-CD137 mAb. For analysis of CD107a upregulation, T cells were incubated with target BLCL at a 1.5:1 ratio for 1 hour in the presence of labeled anti-CD107a mAb, followed by 3-hour incubation with monensin-A (Sigma-Aldrich, Milan, Italy) and staining with appropriately labeled mAb anti-CD4. All T cell effectors were initially tested against DPB1*03:01 by both CD137 and CD107a assays, and the most informative assay, i.e. the assay using the marker with highest specific up-regulation after alloantigen encounter for each $\mathrm{T}$ cell, was selected for further analysis. For mAb inhibition studies, target BLCL were pre-incubated with the relevant unconjugated $\mathrm{mAb}$ at a final concentration of $30 \mu \mathrm{g} / \mathrm{ml}$, before addition of $T$ cell effectors. For target-titration experiments, a fixed number of alloreactive $T$ cells $\left(5^{*} 10^{4}\right)$ was stimulated with 2-fold serial dilutions of target BLCL, starting from an effector:target ratio of 1:1. Results were represented as relative percentage of activated T cells calculated with the following formula: (\% activated cells [target dilution] $_{\text {- }}$ baseline $\left._{[\text {Negative control] }}\right) /\left(\%\right.$ activated cells [undiluted target] $_{\text {- baseline }}$ [Negative control] $)$.

\section{Quantitative assessment of cell surface antigen expression}

Quantitative evaluation of surface antigen expression was performed by converting Median Fluorescence Intensity (MFI) Values into the respective Molecules of Equivalent Soluble Fluorochrome $(\mathrm{MESF})^{25}$, using linear regression analysis of a standard curve generated using SPHERO Rainbow Calibration Particles (Spherotech, Lake Forest, USA) according to the manufacturer's instructions. MESF values were corrected subtracting the MESF value of background fluorescence in unstained cells or in cells stained with secondary antibody alone. Cell staining was performed as follows: BLCL were directly stained with the relevant anti-HLA mAb; PBMC from healthy donors were cultured in the presence or absence of $200 \mathrm{UI} / \mathrm{ml}$ gamma interferon ( $\gamma$-IFN) for 48 hours, then quantitative evaluation of HLA expression was performed on CD3-/CD14+ or CD3-/CD19+ cells after exclusion of dead cells by staining with Live/Dead Fixable Violet Dead Cell Stain Kit (Life Technologies, Monza, Italy).

\section{Lentiviral vector mediated gene transfer of DPB1 into BLCL}

The 6.9Kb full-length cDNA of HLA-DPB1*03:01, DPB1*104:01 and DPB1*01:01 was amplified by RT-PCR from HLA typed BLCL using primers previously described ${ }^{22}$, sequenced and subcloned into a bidirectional promoter lentiviral (LV) expression vector, kindly provided by Professor Luigi Naldini, Milan, Italy ${ }^{26}$. DPB1 and the truncated form of the human low affinity nerve growth factor receptor ( $\triangle$ LNGFR) were under the control of the human phosphoglycerate kinase (hPGK) promoter and a minimal core promoter derived from cytomegalovirus fused to the hPGK promoter in the opposite direction, respectively. Target cells were infected by standard protocols ${ }^{26}$, and purified by magnetic bead selection (Myltenyi Biotec) for the $\Delta$ LNGFR reporter. 


\section{Statistical analyses}

Results of quantitative surface protein expression and of $\mathrm{T}$ cell activation marker upregulation assays are expressed as mean +/- standard error (SE) or standard deviation (SD), respectively, of $n$ independent experiments. Comparative analyses were performed by the unpaired t-test or the one-way ANOVA with the Bonferroni post-test ( $p<0.05$ is considered to be significant). Data of target cell titration experiments were analyzed using dose-response non-linear regression; the goodness of fit was estimated by the $\mathrm{R}^{2}$ index. Statistical comparison of the regression curves was performed using the Extra Sum-of-Squares $F$ test ( $p<0.05$ is considered to be significant). All statistical analyses were carried out using the Graph.Pad Prism 5.0a for Mac OS X software (GraphPad Software, La Jolla CA, USA).

\section{Results}

\section{HLA-DP3 variants and their respective frequency}

The HLA-DP3 antigen is encoded by two allelic variants, DPB1*03:01 and DPB1*104:01, which are identical in the peptide binding groove but differ for a single nucleotide substitution from $\mathrm{G}$ to $\mathrm{A}$ at codon 205 of exon 4, resulting in an amino acid substitution from valine to methionine in the TM domain (Table 3.1$)^{8}$. In order to establish the relative frequency of the two variants, we reviewed high-resolution PCR-SSP HLA-DPB1 typing of 201 VUD, each selected for a different patient referring to the San Raffaele Scientific Institute in Milan for a stem cell donor search. The overall allelic frequency of the two variants taken together was $10.4 \%$, in line with published results in Caucasians $^{18,19}$. The relative frequency of the two variants was $4.2: 1$, with $8.4 \%$ and 2.0\% for DPB1*03:01 and DPB1*104:01, respectively (Table 3.1).

Table 3.1 HLA-DP3 variant frequency and amino acid polymorphism.

\begin{tabular}{lccc}
\hline DPB1 & $\mathrm{N}^{1}$ & Allele Frequency & Amino Acid 205 \\
\hline 03:01 & $34 / 402$ & 8.4 & $\mathrm{M}$ \\
104:01 & $8 / 402$ & 2.0 & $\mathrm{~V}$ \\
Total & $42 / 402$ & 10.4 & $\mathrm{NA}$ \\
\hline
\end{tabular}

\footnotetext{
${ }^{1}$ High resolution genomic HLA-DPB1 typing was performed on 201 VUD referring to the laboratory in Milan,
} for a total of 402 DPB1 alleles. NA not applicable.

\section{Cell surface expression levels of the HLA-DP3 variants}

In order to investigate the functional effect of the outside-the-groove polymorphism in the two HLA-DP3 variants, we first performed a quantitative analysis of HLA-DP expression levels on a panel of BLCL expressing endogenous DPB1*03:01 ( $n=5)$, DPB1*104:01 $(n=4)$ or negative for the two alleles $(n=5)$ (Table S3.1; Figure 3.1A). 
HLA-DP3+ BLCL were selected to be heterozygous for DPB1*04 (either DPB1*04:01 or *04:02) as second allele, in order to adjust for possible, unknown variability of the nonHLA-DP3 allele co-expressed in heterozygous cells. No significant differences in HLA-DR or DP expression were observed between the $14 \mathrm{BLCL}$ studied. In particular, HLA-DP expression levels were similar in BLCL carrying DPB1*03:01 or DPB1*104:01 (Table S3.1; Figure 3.1A).

A

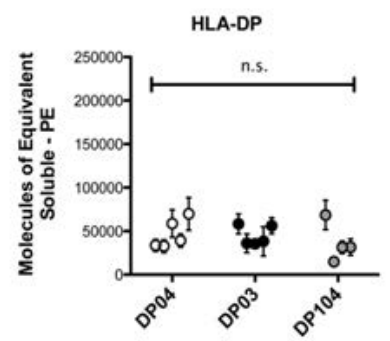

BLCL

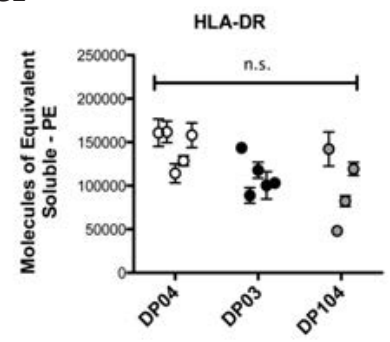

B

Primary B cells

HLA-DP

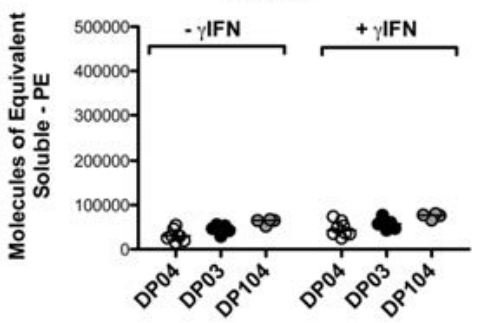

HLA-DR

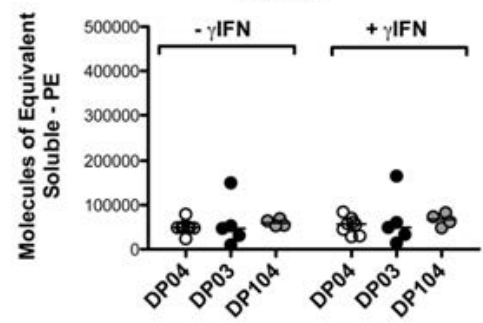

C

\section{Monocvtes}
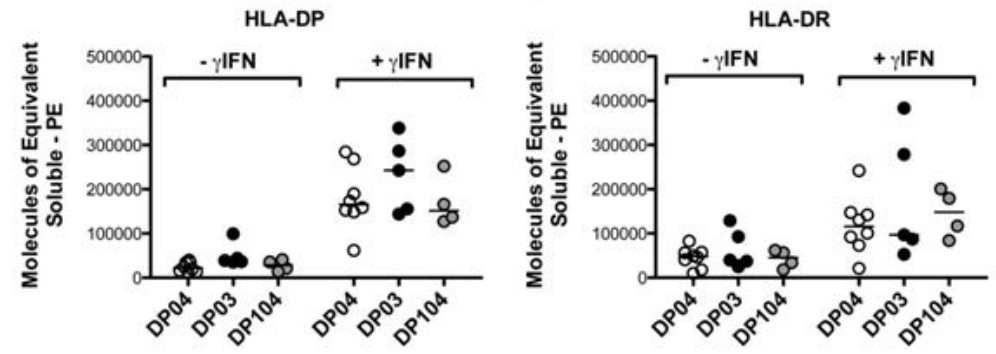

Figure 3.1 Quantification of HLA-DP cell surface expression levels on cells carrying DPB1*03:01 or DPB1*104:01. Cell surface expression levels of HLA-DP (mAb B7/21) or HLA-DR (mAb L243), were quantified as molecules of equivalent soluble fluorochrome (MESF). The following cell types were studied: (A) BLCL typed as DPB1*04 ( $=5)$, DPB1*03:01, ${ }^{*} 04 \quad(n=5)$ or DPB1*104:01, ${ }^{*} 04(n=4)$ (Table S3.1), results are reported as means \pm SE of three independent experiments; n.s. not significant as determined by one-way ANOVA test. (B-C) primary B cells or monocytes typed as DPB1*04 $(n=8)$, DPB1*03:01, ${ }^{*} 04(n=5)$ or DPB1*104:01, ${ }^{* 04}(n=4)(T a b l e$ S3.2) before or after 48-hour incubation with $\gamma$-IFN as indicated. DPB1*04 refers to either DPB1*04:01 or *04:02. 
Next, we studied HLA-DP expression levels on primary B cells and monocytes, chosen for their well-known antigen presenting capacity in vivo, and selected to be heterozygous for DPB ${ }^{*} 04$ as second allele as described above (Table S3.2). B cells and monocytes were analyzed before or after induction of HLA class II expression by $\gamma$-IFN for 48 hours. As previously reported ${ }^{27}, \gamma$-IFN incubation led to a significant upregulation of both HLA-DR $(p<0.0001)$ and HLA-DP $(p<0.0001)$ on monocytes but not on $B$ cells (Figure $3.1 B-C$ ). In contrast, no significant differences between HLA-DR or HLA-DP expression were detected when comparing $B$ cells or monocytes expressing endogenous DPB1*03:01 $(n=5)$, DPB1*104:01 $(n=4)$ or negative for the two alleles $(n=8)$ within the same condition, i.e. before or after $\gamma$-IFN incubation (Figure 3.1B-C).

\section{T cell allorecognition of BLCL endogenously expressing the HLA-DP3 variants}

We next investigated the effect of the outside-the-groove polymorphism in the two HLA-DP3 variants on recognition by established alloreactive T cell effectors. We used cytofluorometric measurement of activation marker upregulation as read-out for alloantigen recognition. As markers, we tested CD137, a member of the TNF receptor superfamily used as co-stimulatory molecule by some but not all T cells ${ }^{28}$, and CD107a a degranulation marker informative mainly in T cells endowed with cytotoxic activity ${ }^{29}$. Both markers were tested for all effectors and the marker that gave the highest specific response was selected for further assays of each effector.

Three effector $T$ cells, designated C2-DK/DK-3, C11-DK/MN-3 and M3-VR/FV-3, respectively, alloreactive to HLA-DP3 encoded by DPB1*03:01 were obtained from appropriately HLA-typed MLR from three different R-S pairs (Table S3.3). C2-DK/DK-3 and $\mathrm{C} 11-\mathrm{DK} / \mathrm{MN}-3$, isolated by limiting dilution cloning, showed specific $\gamma$-IFN production or lytic activity upon challenge with the original allogeneic S-BLCL, but not with autologous R-BLCL (data not shown). In line with their cytotoxic potential, these two effectors also showed specific upregulation of the degranulation marker CD107a upon stimulation by the original S-BLCL, which was inhibited by $m A b s$ specific for HLA-DP but not HLA-DR or HLA class I (Figure 3.2). M3-VR/FV-3, isolated by repeated polyclonal stimulation, showed specific upregulation of the activation marker CD137 upon challenge with the original allogeneic S-BLCL, but not with autologous R-BLCL, which was inhibited by mAbs specific for HLA-DP and DR but not HLA class I (Figure 3.2). M3-VR/FV-3 was comprised of an oligoclonal T cell population as assessed by TCR-Vbeta staining (data not shown), suggesting the presence of distinct T cell effectors respectively restricted to HLA-DP and DR. The latter might recognize an HLA-DP3derived allopeptide restricted by self-HLA-DR3 (Table S3.3), as suggested by the inability of the M3-VR/FV-3 to up-regulate CD137 in response to BLCL expressing selfHLA-DR3 in the absence of allogeneic HLA-DP3 (data not shown). 

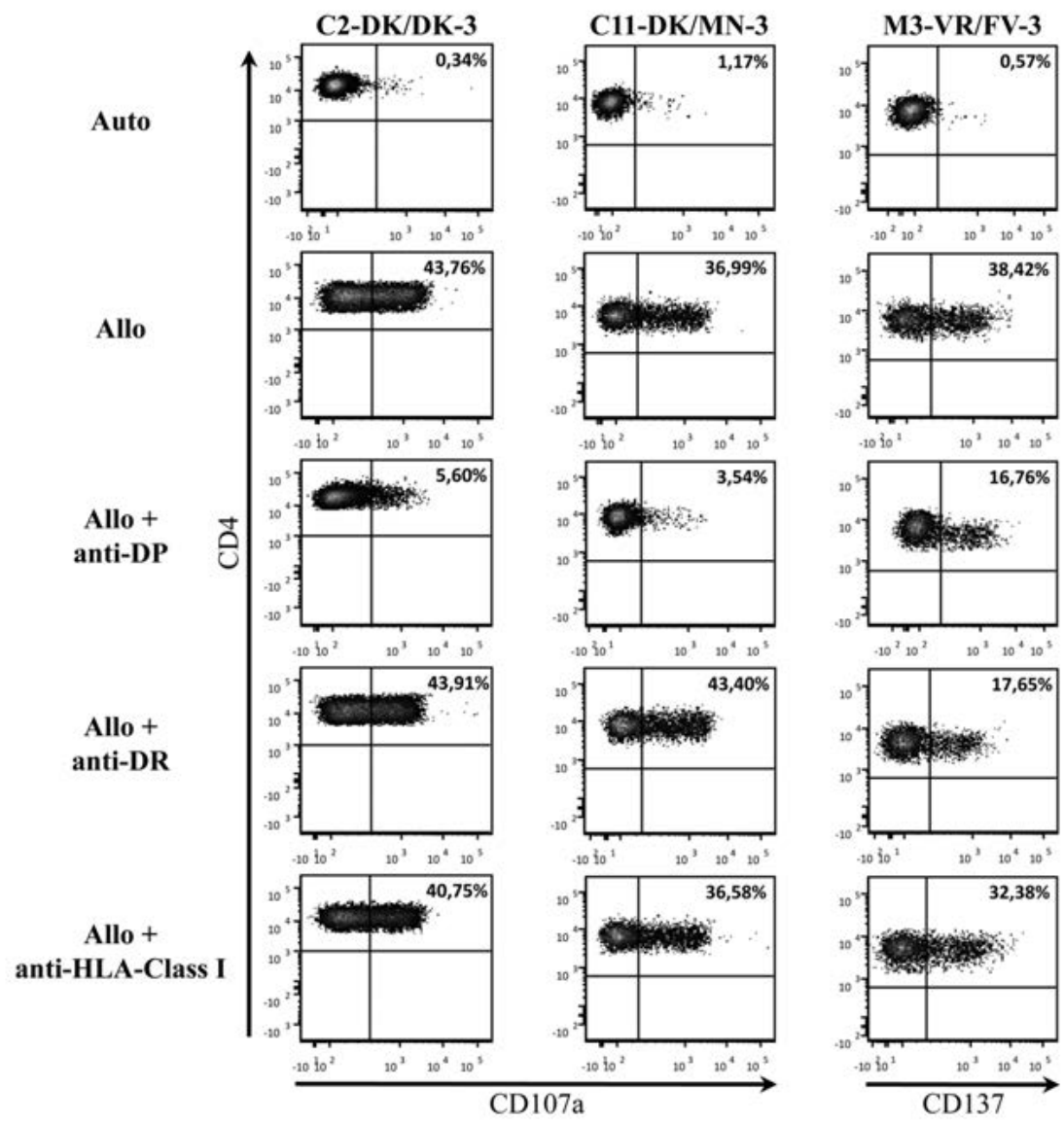

Figure 3.2 Allospecificity of T cell effectors used in this study. T cell effectors C2-DK/DK-3, C11-DK/MN-3 and M3-VR/FV-3 were obtained by limiting dilution cloning or by repeated polyclonal stimulation from MLR between three different R-S pairs mismatched for HLA-DPB1*03:01 (Table S3.3). The alloantigen specificity of each effector was measured by up-regulation of the activation marker CD107a (C2-DK/DK-3 and C11-DK/MN-3) or CD137 (M3-VR/FV-3) after secondary stimulation with autologous (auto) or allogeneic (allo) stimulator $\mathrm{BLCL}$, in the presence or absence of $30 \mu \mathrm{g} / \mathrm{ml}$ of blocking anti-HLA mAb as indicated.

In line with their established HLA-DP restricted allospecificity, all three effectors showed specific activation marker upregulation after incubation with a third party BLCL carrying DPB1*03:01 but not DPB1*04:01 as negative control (Figure 3.3A). The percentage of activated cells in response to third party BLCL carrying the HLA-DP3 variant DPB1*104:01 was similar to that of DPB1*03:01 for each of the three effectors (Figure 3.3A). This was confirmed by statistical analysis of five and four BLCL carrying DPB1*03:01 or DPB1*104:01, respectively (Figure 3.3B). 
A

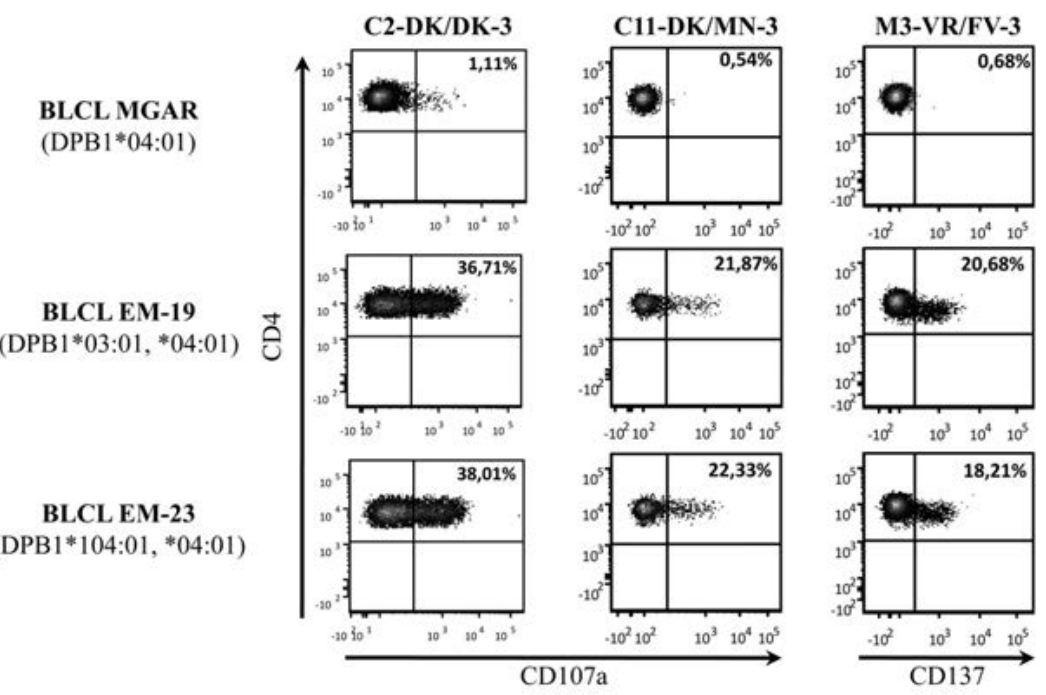

B

C2-DK/DK-3

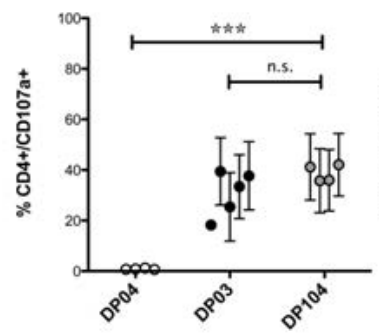

C11-DK/MN-3

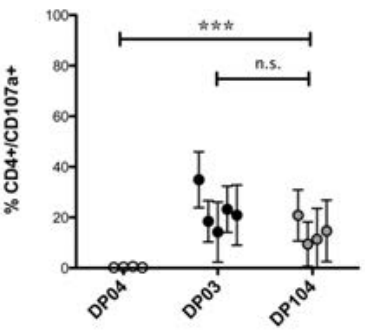

M3-VR/FV-3

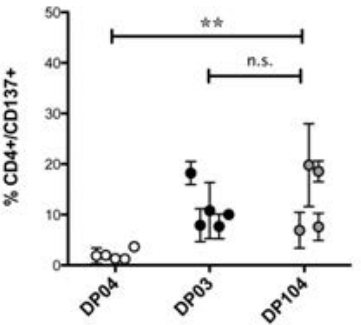

Figure 3.3 T cell allorecognition of HLA-DP3 variants endogenously expressed by BLCL. (A) Representative dot plot of activation marker upregulation by three $T$ cell effectors alloreactive to HLA-DP3, upon secondary stimulation with third party BLCL expressing DPB1*04:01 (MGAR), DPB1*03:01 (EM-19), or DPB1*104:01 (EM-23). (B) Summary of the results obtained for each alloreactive $\mathrm{T}$ cell effector upon secondary stimulation with a panel of third party $\mathrm{BLCL}$ expressing DPB1*04:01, DPB1*03:01, or DPB1*104:01 (Table S3.1). Results are reported as mean $\pm S D$ of 3 independent experiments. Statistical analyses were performed using one-way ANOVA with Bonferroni post-test comparison between the DPB1*03:01 and DPB1*104:01 groups (n.s. not significant, $* * p<0.01, * * * p<0.001$ ).

\section{T cell allorecognition of the two HLA-DP3 variants in the same cellular background}

In order to rule out the possible influence of differentially expressed allopeptides, as well as of DPA1 polymorphism, on T cell allorecognition of HLA-DP3 endogenously expressed by BLCL from different individuals, we performed LV-mediated gene transfer of DPB1*03:01, DPB1*104:01 or irrelevant DPB1*01:01 into the read-out BLCL MGAR, 
homozygous for endogenous DPA1*01:03 and DPB1*04:01. After magnetic beads purification for the $\triangle$ LNGFR reporter, MGAR transduced with DPB1*03:01 (MGARDP03) showed somewhat higher cell surface expression levels of the reporter compared to MGAR transduced with DPB1*104:01 (MGAR-DP104) or with DPB1*01:01 (MGAR-DP01; Figure 3.4A, left panel). This was reflected by higher levels of cell surface DEAV $_{(84-87)}$ HLA-DP molecules on MGAR-DP03 compared to the other two, but this difference was not statistically significant (Figure 3.4A, right panel).

In line with their allospecificity, neither of our three alloreactive T cell effectors (Table S3.3) showed specific activation marker upregulation in response to untransduced MGAR or to MGAR-DP01. In contrast, high levels of specific activation marker upregulation were observed in response to both MGAR-DP03 and MGAR-DP104 (Figure 3.4B). No statistical difference was observed in ten independent experiments, for activation marker upregulation by either of the three effectors in response to MGAR-DP03 compared to MGAR-DP104 (Figure 3.4C). In order to determine possible differences in alloantigen thresholds between the two HLA-DP3 variants, we performed target cell titration experiments. Again, statistical comparison of the non-linear regression curves showed no significant differences between the two variants (Figure 3.4D).

\section{Discussion}

In the present study, we have made a detailed analysis of the effect of a point mutation at amino acid position 205 in the TM region of HLA-DP3 on cell surface expression and allorecognition. Such an effect could be postulated to occur in different ways. First, amino acid changes in the TM region could alter cell surface expression levels by directly interfering with the molecule's anchorage in the cell membrane, as suggested by analysis of a chemically induced TM region mutation of HLA-DP ${ }^{30}$. Second, polymorphisms in the TM region could interfere with co-localization of HLA-DR and DM during peptide processing ${ }^{31}$, thereby potentially impacting on the peptide repertoire and/or processing efficiency. Third, TM region amino acids have been shown to be involved in post-translational control of HLA class II expression by ubiquitination ${ }^{32}$. Finally, a direct effect on $\mathrm{T}$ cell allorecognition could be postulated by mechanisms analogous to those operating in HLA-C mediated inhibition of NK cell cytotoxicity, which was shown to be dependent on the TM region of the HLA molecule $e^{33}$. 
A

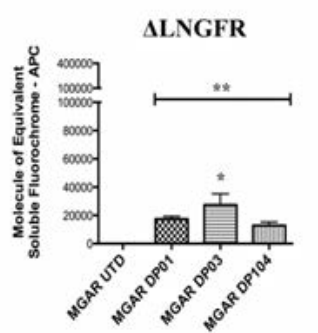

HLA-DP (DEAV+)

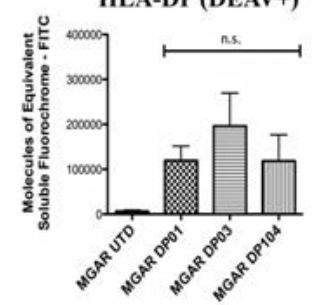

B
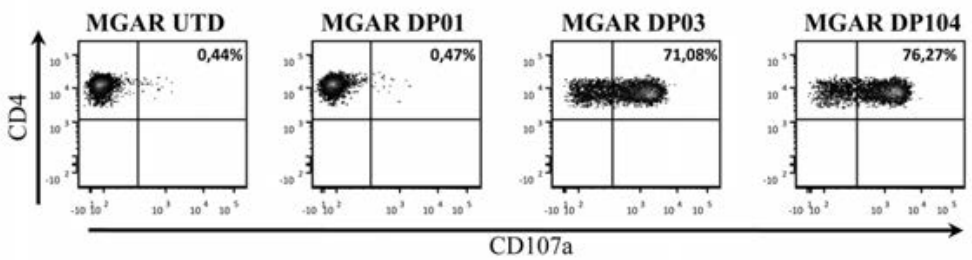

C

C2-DK/DK-3

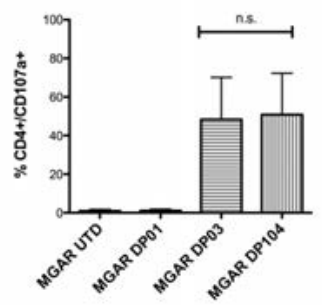

D

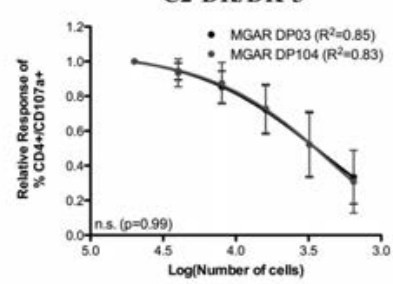

C11-DK/MN-3

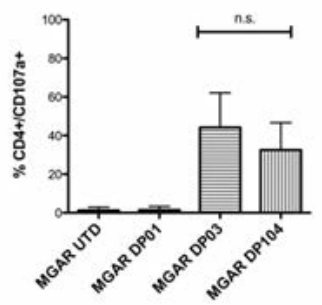

C11-DK/MN-3

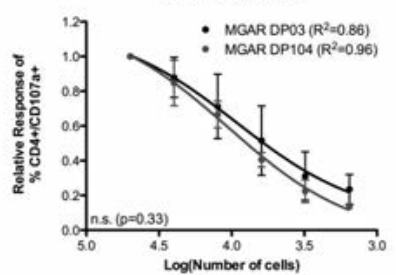

M3-VR/FV-3

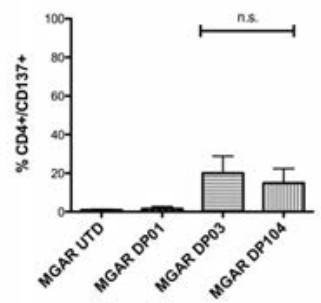

M3-VR/FV-3

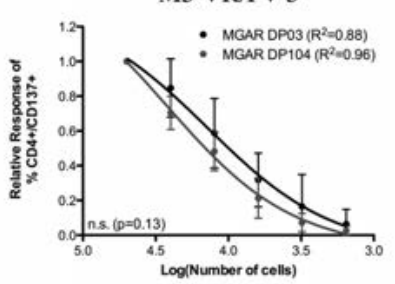

Figure 3.4 T cell allorecognition of HLA-DP3 variants in the same cellular background. MGAR BLCL, homozygous for endogenous DPB $1 * 04: 01$, were left untransduced (UTD) or transduced with LV particles bearing the coding sequence of DPB1*01:01 (MGAR DP01), DPB1*03:01 (MGAR DP03) or DPB1*104:01 (MGAR DP104). (A) Cell surface expression of the LV-encoded $\triangle$ LNGFR reporter (left panel; mAb ME20.4) or HLA-DP (right panel; mAb TL-3B6 specific for the HLA-DP epitope DEAV(84-87)) on MGAR UTD, MGAR DP01, MGAR DP03 or MGAR DP104. Results are the means $\pm S E$ of three independent experiments. Statistical analyses were performed using one-way ANOVA and Bonferroni post-test comparison between all transduced BLCL (n.s. not significant, $* p<0.05 * * p<0.01$ ). (B) Representative dot plot of CD107a upregulation by alloreactive T cell effector C2-DK/DK-3 in response to MGAR UTD, MGAR DP01, MGAR DP03 or MGAR DP104. (C) $T$ cell allorecognition measured by up-regulation of the activation marker CD107a (C2-DK/DK-3 and C11-DK/MN-3) or CD137 (M3-VR/FV-3) after secondary stimulation with MGAR UTD, MGAR DP01, MGAR DP03 or MGAR DP104. Results from ten independent experiments for each effector are reported as mean $\pm S D$ percentage of activated $T$ cells. 


\begin{abstract}
Statistical comparison between T cell recognition of DP03 and DP104 was performed using the two-tailed t test. n.s. not significant. (D) Target cell titration experiments. Alloreactive T cells were stimulated against 2-fold serial dilutions of each target BLCL. Results from three independent experiments are expressed as mean \pm SD percentage of activated $T$ cells relative to the first dilution point. Statistical comparison between DP03 and DP104 was performed using the Extra Sum-of-Squares F test (n.s. not significant).
\end{abstract}

Our results show that the methionine to valine substitution in the TM region of HLA-DP3 does not have a significant impact on surface expression and allorecognition by established effector T cells. This was demonstrated by quantitative measurement of molecular equivalents of soluble fluorochrome for cell surface expression both on BLCL and on primary $B$ cells and monocytes, and by analysis of activation marker upregulation by three $T$ cell effectors alloreactive to HLA-DP3 obtained from three different individuals. In particular, potentially confounding effects on $\mathrm{T}$ cell alloreactivity mediated by DP-alpha chain polymorphism or allopeptide repertoires were ruled out by investigating allorecognition of HLA-DP3 in the same cellular background. To our best knowledge, this is the first study to directly compare the impact of an outside-the-groove polymorphism on $\mathrm{T}$ cell alloreactivity. Similar peptide binding motifs have been reported for HLA-B*44:02 and B*44:27 differing for a single amino acid in the alpha3 domain ${ }^{14}$. Altered expression levels have been demonstrated for certain outside-the-groove variants, which are reflected by relevant suffixes in the HLA nomenclature (www.ebi.ac.uk/imgt/hla) ${ }^{10}$. However, these parameters cannot be regarded as surrogates for direct measurement of $\mathrm{T}$ cell alloreactivity. It should be noted that our study addresses the effector arm of alloreactivity, and not the induction arm, since we did not have the opportunity to comparatively measure the strength or frequency of the alloreactive T cell response in MLRs mismatched only for DPB1*03:01 or DPB1*104:01, due to the lack of appropriately HLA-typed R-S PBMC. However, due to the allelic frequencies of both alleles, this situation is quite rare and occurred in only 3/99 (3\%) unrelated donor searches performed at our institution since 2011. Likewise, we could not comparatively analyze alloreactive $T$ cell responses ex-vivo from patients after unrelated HSCT, because none of the patients from the centers participating in this study were transplanted from appropriately mismatched VUD. Therefore, the possibility that the amino acid substitution in the TM region might be processed by certain HLA specificities and give rise to a clinically relevant minor histocompatibility antigen, cannot be formally ruled out.

HLA-DP3 has been classified by our previous biological and clinical studies into one of three distinct $T$ cell epitope (TCE) groups relevant for functional matching in unrelated $\mathrm{HSCT}^{19-21}$. DPB1*03:01 and DPB1*104:01, the two allelic variants encoding HLA-DP3 beta-chain, are not discriminated by most laboratories following the international guidelines for high resolution histocompatibility typing ${ }^{7}$, and their relative frequency in different ethnic groups is unknown. We show that in a population of unrelated stem cell donors selected for patients mostly of Caucasian origin, the two HLA-DP3 variants 
occur with a relative frequency of 4.2:1. The ethnic origin of the donors was unknown to us but it is likely that most of them were of Caucasian origin as well, because the probability to find an HLA-matched VUD is highest within the same ethnic group. In support of this, the overall allelic frequency of DPB1*03:01 and DPB1*104:01 taken together in our study population was $10.4 \%$, corresponding to the reported frequency of alleles encoding HLA-DP3 in Caucasians but not in other ethnic groups ${ }^{17,18}$. In line with this, in a series of 99 unrelated donor searches performed at our institution since 2011, DPB1*104:01 was identified either in the patient or in a potential unrelated donor in 10 cases $(10.1 \%)$, further hinting to the practical relevance of its functional role. The results reported here are compatible with the current notion to regard the two HLA-DP3 variants, DPB1*03:01 and DPB1*104:01, as a functional entity in unrelated stem cell donor searches. Although this piece of evidence might also be considered as new biological support for international guidelines limiting the requirements for high resolution typing of expressed HLA alleles to those differing inside the antigen binding groove ${ }^{7}$, care should be taken in making generalizations given the large heterogeneity of outside the groove amino acid polymorphisms throughout the HLA system. Further functional studies are clearly warranted to comprehensively address this important issue.

\section{Acknowledgements}

The authors would like to thank Sir Walter Bodmer (The Cancer Institute, London, UK) and to Professor Luigi Naldini (HSR-TIGET, Milan, Italy) for providing the anti-HLA-DP $\mathrm{mAb}$ B7/21 and the bidirectional promoter lentiviral-vector backbone, respectively.

This work was supported by grant IG12042 from the Associazione Italiana per la Ricerca sul Cancro (AIRC). NL was supported by a bursary from the European Federation for Immunogenetics (EFI). 


\section{References}

1. Little AM, Parham P. Polymorphism and evolution of HLA class I and II genes and molecules. Rev Immunogenet 1999;1:105-23.

2. Klein J, Sato A. The HLA system. First of two parts. N Engl J Med 2000;343:702-9.

3. Ferrara GB, Bacigalupo A, Lamparelli T, Lanino E, Delfino L, Morabito A, Parodi AM, Pera C, Pozzi S, Sormani MP, Bruzzi P, Bordo D, Bolognesi M, Bandini G, Bontadini A, Barbanti M, Frumento G. Bone marrow transplantation from unrelated donors: the impact of mismatches with substitutions at position 116 of the human leukocyte antigen class I heavy chain. Blood 2001;98:3150-5.

4. Flomenberg N, Baxter-Lowe LA, Confer D, Fernandez-Vina M, Filipovich A, Horowitz M, Hurley C, Kollman C, Anasetti C, Noreen H, Begovich A, Hildebrand W, Petersdorf E, Schmeckpeper B, Setterholm M, Trachtenberg E, Williams T, Yunis E, Weisdorf D. Impact of HLA class I and class II high-resolution matching on outcomes of unrelated donor bone marrow transplantation: HLA-C mismatching is associated with a strong adverse effect on transplantation outcome. Blood 2004;104:1923-30.

5. Lee SJ, Klein J, Haagenson M, Baxter-Lowe LA, Confer DL, Eapen M, Fernandez-Vina M, Flomenberg N, Horowitz M, Hurley CK, Noreen H, Oudshoorn M, Petersdorf E, Setterholm M, Spellman S, Weisdorf D, Williams TM, Anasetti C. High-resolution donor-recipient HLA matching contributes to the success of unrelated donor marrow transplantation. Blood 2007;110:4576-83.

6. Petersdorf EW, Malkki M, Hsu K, Bardy P, Cesbron A, Dickinson A, Dubois V, Fleischhauer K, Kawase T, Madrigal A, Morishima Y, Shaw B, Spellman S, Spierings E, Stern M, Tiercy JM, Velardi A, Gooley T; International Histocompatibility Working Group in Hematopoietic Cell Transplantation. 16th IHIW: international histocompatibility working group in hematopoietic cell transplantation. Int J Immunogenet 2013;40:2-10.

7. Nunes E, Heslop H, Fernandez-Vina M, Taves C, Wagenknecht DR, Eisenbrey AB, Fischer G, Poulton K, Wacker K, Hurley CK, Noreen H, Sacchi N. Definitions of histocompatibility typing terms. Blood 2011;118:e180-3.

8. Reinders J, Rozemuller EH, van Gent R, Arts-Hilkes YH, van den Tweel JG, Tilanus MG. Extended HLADPB1 polymorphism: an RNA approach for HLA-DPB1 typing. Immunogenetics 2005;57:790-4.

9. Lauterbach N, Voorter CE, Stallinga CM, Groeneweg M, Wieten L, Tilanus MG. Full-length HLA-DPB1 diversity in multiple alleles of individuals from Caucasian, Black, or Oriental origin. Tissue Antigens 2012;79:165-73.

10. Robinson J, Mistry K, McWilliam H, Lopez R, Parham P, Marsh SG. The IMGT/HLA database. Nucleic Acids Res 2011;39(Database issue):D1171-6.

11. Magor KE, Taylor EJ, Shen SY, Martinez-Naves E, Valiante NM, Wells RS, Gumperz JE, Adams EJ, Little AM, Williams F, Middleton D, Gao X, McCluskey J, Parham P, Lienert-Weidenbach K. Natural inactivation of a common HLA allele $\left(A^{*} 2402\right)$ has occurred on at least three separate occasions. J Immunol 1997;158:5242-50.

12. Elsner HA, Blasczyk R. Immunogenetics of HLA null alleles: implications for blood stem cell transplantation. Tissue Antigens 2004;64:687-95.

13. Dunn PP, Hammond L, Coates E, Street J, Griner L, Darke C. A "silent" nucleotide substitution in exon 4 is responsible for the "alternative expression" of HLA-A*01:01:38L through aberrant splicing. Hum Immunol 2011;72:717-22.

14. Bade-Doeding C, Cano P, Huyton T, Badrinath S, Eiz-Vesper B, Hiller O, Blasczyk R. Mismatches outside exons 2 and 3 do not alter the peptide motif of the allele group B*44:02P. Hum Immunol 2011;72: 1039-44.

15. Xiao Y, Lazaro AM, Masaberg C, Haagenson M, Vierra-Green C, Spellman S, Dakshanamurthy S, Ng J, Hurley CK. Evaluating the potential impact of mismatches outside the antigen recognition site in unrelated hematopoietic stem cell transplantation: HLA-DRB1*1454 and DRB1*140101. Tissue Antigens 2009;73:595-8.

16. Pasi A, Crocchiolo R, Bontempelli M, Carcassi C, Carella G, Crespiatico L, Garbarino L, Mascaretti L, Mazzi B, Mazzola G, Miotti V, Porfirio B, Tagliaferri C, Valentini T, Vecchiato C, Fleischhauer K, Sacchi N, Bosi A, Martinetti M. The conundrum of HLA-DRB1*14:01/*14:54 and HLA-DRB3*02:01/*02:02 mismatches in unrelated hematopoietic SCT. Bone Marrow Transplant 2011;46:916-22. 
17. Zino E, Vago L, Di Terlizzi S, Mazzi B, Zito L, Sironi E, Rossini S, Bonini C, Ciceri F, Roncarolo MG, Bordignon C, Fleischhauer K. Frequency and targeted detection of HLA-DPB1 T cell epitope disparities relevant in unrelated hematopoietic stem cell transplantation. Biol Blood Marrow Transplant 2007; 13:1031-40.

18. Hollenbach JA, Madbouly A, Gragert L, Vierra-Green C, Flesch S, Spellman S, Begovich A, Noreen H, Trachtenberg E, Williams T, Yu N, Shaw B, Fleischhauer K, Fernandez-Vina M, Maiers M. A combined DPA1 approximately DPB1 amino acid epitope is the primary unit of selection on the HLA-DP heterodimer. Immunogenetics 2012;64:559-69.

19. Zino E, Frumento G, Marktel S, Sormani MP, Ficara F, Di Terlizzi S, Parodi AM, Sergeant R, Martinetti M, Bontadini A, Bonifazi F, Lisini D, Mazzi B, Rossini S, Servida P, Ciceri F, Bonini C, Lanino E, Bandini G, Locatelli F, Apperley J, Bacigalupo A, Ferrara GB, Bordignon C, Fleischhauer K. A T-cell epitope encoded by a subset of HLA-DPB1 alleles determines nonpermissive mismatches for hematologic stem cell transplantation. Blood 2004;103:1417-24.

20. Crocchiolo R, Zino E, Vago L, Oneto R, Bruno B, Pollichieni S, Sacchi N, Sormani MP, Marcon J, Lamparelli T, Fanin R, Garbarino L, Miotti V, Bandini G, Bosi A, Ciceri F, Bacigalupo A, Fleischhauer K; Gruppo Italiano Trapianto di Midollo Osseo, Cellule Staminale Ematopoietiche (CSE) e Terapia Cellulare; Italian Bone Marrow Donor Registry. Nonpermissive HLA-DPB1 disparity is a significant independent risk factor for mortality after unrelated hematopoietic stem cell transplantation. Blood 2009;114: 1437-44.

21. Fleischhauer K, Shaw BE, Gooley T, Malkki M, Bardy P, Bignon JD, Dubois V, Horowitz MM, Madrigal JA, Morishima Y, Oudshoorn M, Ringden O, Spellman S, Velardi A, Zino E, Petersdorf EW; International Histocompatibility Working Group in Hematopoietic Cell Transplantation. Effect of T-cell-epitope matching at HLA-DPB1 in recipients of unrelated-donor haemopoietic-cell transplantation: a retrospective study. Lancet Oncol 2012;13:366-74.

22. Fleischhauer K, Zino E, Mazzi B, Sironi E, Servida P, Zappone E, Benazzi E, Bordignon C. Peripheral blood stem cell allograft rejection mediated by CD4(+) T lymphocytes recognizing a single mismatch at HLADP beta 1*0901. Blood 2001;98:1122-6.

23. Betts MR, Brenchley JM, Price DA, De Rosa SC, Douek DC, Roederer M, Koup RA. Sensitive and viable identification of antigen-specific CD8+ T cells by a flow cytometric assay for degranulation. $J$ Immunol Methods 2003;281:65-78.

24. Wolfl M, Kuball J, Ho WY, Nguyen H, Manley TJ, Bleakley M, Greenberg PD. Activation-induced expression of CD137 permits detection, isolation, and expansion of the full repertoire of CD8+ T cells responding to antigen without requiring knowledge of epitope specificities. Blood 2007;110:201-10.

25. Schwartz A, Gaigalas AK, Wang L, Marti GE, Vogt RF, Fernandez-Repollet E. Formalization of the MESF unit of fluorescence intensity. Cytometry B Clin Cytom 2004;57:1-6.

26. Amendola M, Venneri MA, Biffi A, Vigna E, Naldini L. Coordinate dual-gene transgenesis by lentiviral vectors carrying synthetic bidirectional promoters. Nat Biotechnol 2005;23:108-16.

27. Gonwa TA, Frost JP, Karr RW. All human monocytes have the capability of expressing HLA-DQ and HLADP molecules upon stimulation with interferon-gamma. J Immunol 1986;137:519-24.

28. Vinay DS, Kwon BS. Immunotherapy of cancer with 4-1BB. Mol Cancer Ther 2012;11:1062-70.

29. Suni MA, Maino VC, Maecker HT. Ex vivo analysis of T-cell function. Curr Opin Immunol 2005;17: 434-40.

30. Arroyo J, Diez-Orejas R, Alvarez AM, Shaw S, Sanchez-Perez M. Molecular analysis of an HLA-DP mutant cell line selected for its resistance to killing by HLA-DPw2-specific T-cell clones. Immunogenetics 1994;39:40-7.

31. Weber DA, Dao CT, Jun J, Wigal JL, Jensen PE. Transmembrane domain-mediated colocalization of HLADM and HLA-DR is required for optimal HLA-DM catalytic activity. J Immunol 2001;167:5167-74.

32. Jahnke M, Trowsdale J, Kelly AP: Structural requirements for recognition of MHC class II by MARCH E3 ligases. J Biol Chem 2012;287:28779-89.

33. Davis DM, Mandelboim O, Luque I, Baba E, Boyson J, Strominger JL. The transmembrane sequence of human histocompatibility leukocyte antigen (HLA)-C as a determinant in inhibition of a subset of natural killer cells. J Exp Med 1999;189:1265-74. 


\section{Supplementary data}

Table S3.1 BLCL used in this study.

\begin{tabular}{|c|c|c|c|c|c|c|c|}
\hline \multirow{2}{*}{$\mathrm{BLCL}^{1}$} & \multicolumn{6}{|c|}{$H L A^{2}$} & \multirow{2}{*}{$\begin{array}{c}\text { HLA-DP }{ }^{3} \\
\text { MESF (Mean } \pm S E)\end{array}$} \\
\hline & $A^{*}$ & B* & $\mathrm{C}^{*}$ & DRB1* & DQB1* & DPB1* & \\
\hline EM-15 & $24: 02,30: 01$ & 51,13 & $16: 02,06$ & 07:01, 16:01 & 03:03, 05:02 & $04: 02,03: 01$ & $56,255 \pm 5,290$ \\
\hline EM-16 & 02:05, 24:02 & $35: 03,58: 01$ & $12: 03,07: 18$ & $04: 05,14: 54$ & $03: 02,05: 03$ & 04:02, 03:01 & $38,290 \pm 9,674$ \\
\hline EM-17 & 02:01, 68:01 & 51:01, 18:01 & $15: 02,05: 01$ & 11:01, 03:01 & 03:01, 02:01 & 04:01, 03:01 & $35,444 \pm 2,447$ \\
\hline EM-18 & 02:01, 24:02 & $35: 02,51: 01$ & 04:01, 14 & $11: 04,15: 01$ & 03:01, 06:02 & 04:01, 03:01 & $36,015 \pm 6,213$ \\
\hline EM-19 & 01:01 & $57: 01,08: 01$ & 07:01 & $13: 03,03: 01$ & 03:01, 02:01 & 04:01, 03:01 & $58,363 \pm 6,518$ \\
\hline EM-20 & $24: 02,11: 01$ & $18: 01,41: 02$ & $12: 03,17: 03$ & 07:01, 11:04 & 02:02, 03:01 & 04:02, 104:01 & $31,595 \pm 5,438$ \\
\hline EM-21 & 02:01, 01:01 & $38: 01,51: 01$ & $12: 03,16: 01$ & $11: 02,14: 54$ & $03: 19,05: 03$ & $105: 01^{4} 104: 01$ & $31,391 \pm 4,117$ \\
\hline EM-22 & 02.01, 11:01 & $35: 02,52: 01$ & 04:01, 12:02 & $11: 04,15: 02$ & 03:01, 06:01 & 04:01, 104:01 & $14,828 \pm 2.133$ \\
\hline EM-23 & 03:01, 68:02 & $41: 02,53: 01$ & $17: 03,04: 01$ & $13: 03,13: 02$ & 03:01, 06:04 & 04:01, 104:01 & $68,573 \pm 9,791$ \\
\hline EM-24 & 03:01, 11:12 & $18: 01,55: 01$ & 07, 03:03 & $16: 01,11: 01$ & 05:02, 03:01 & 04:01 & $39,044 \pm 4,351$ \\
\hline EM-25 & 01:01, 31:01 & $35: 01,35: 03$ & 04:01 & 01:01, 11:01 & 05:01, 03:01 & 04:01 & $32,714 \pm 4,276$ \\
\hline EM-9 & $11: 01,24: 02$ & $51: 01,35: 03$ & $15: 02,12: 03$ & $11: 01,11: 04$ & 03:01 & 04:02 & $33,681 \pm 3,937$ \\
\hline SWEIG007 & 29:02 & $40: 02$ & $02: 02$ & 11:01 & 03:01 & 04:02 & $69,849 \pm 10,797$ \\
\hline MGAR & $26: 01$ & 08:01 & 07:01 & $15: 01$ & 06:02 & 04:01 & $58,713 \pm 9,128$ \\
\hline
\end{tabular}

${ }^{1}$ BLCL were locally established according to standard protocols, except for MGAR and SWEIG007 which were purchased from the ECACC. ${ }^{2}$ Genomic HLA typing was obtained from the PBMC used to generate locally established BLCL, except for SWEIG007 and MGAR for which ECACC typing is reported. ${ }^{3}$ HLA-DP cell surface expression was quantified as molecules of equivalent soluble fluorochrome (MESF) using mAb B7/21. Data are presented as mean \pm SE of 3 independent experiments. ${ }^{4}$ DPB1*105:01 is identical to DPB1*04:02 except for a single nucleotide substitution at codon 178.

Table S3.2 HLA typing of PBMCs used for obtention of primary B cells and monocytes in this study.

\begin{tabular}{|c|c|c|c|c|c|c|}
\hline \multirow{2}{*}{$\mathrm{PBMC}^{1}$} & \multicolumn{6}{|l|}{ HLA } \\
\hline & $A^{*}$ & $\mathrm{~B}^{*}$ & $\mathrm{C}^{*}$ & DRB1* & DQB1* & DPB1* \\
\hline$\# 1$ & 02:01, 11:01 & $51: 01,57: 01$ & $06: 02,15: 02$ & 04:04, 07:01 & 03:02, 03:03 & 04:02, 03:01 \\
\hline$\# 2$ & $02: 05,24: 02$ & $35: 03,58: 01$ & $07: 18,12: 03$ & $04: 05,14: 54$ & 03:02, 05:03:01 & $04: 02,03: 01$ \\
\hline$\# 3$ & 02:01, 32:01 & $18: 01,35: 01$ & 04:01, 07:01 & 01:01, 11:04 & 03:01, 05:01 & 04:02, 03:01 \\
\hline$\# 4$ & $24: 02,32: 02$ & $27: 08,39: 01$ & $06: 02,12: 03$ & $11: 01,13: 01$ & 03:01, 06:03 & 04:01, 03:01 \\
\hline$\# 5$ & 02:01 & $13: 02,58: 01$ & 06:02, 07:01 & 04:05, 07:01 & $02: 02,03: 02$ & 04:02, 03:01 \\
\hline$\# 6$ & $11: 01,24: 02$ & $18: 01,41: 02$ & $12: 03,17: 03$ & 07:01, 11:04 & $02: 02,03: 01$ & 04:02, 104:01 \\
\hline$\# 7$ & 02:01, 11:01 & $35: 02,52: 01$ & $04: 01,12: 02$ & $11: 04,15: 02$ & 03:01, 06:01 & 04:01, 104:01 \\
\hline$\# 8$ & 24:02, 33:01 & $14: 02,35: 02$ & 04:01, 08:02 & 01:02, 11:04 & 03:01, 05:01 & 04:01, 104:01 \\
\hline$\# 9$ & 01:01, 02:01 & $38: 01: 01,51: 01$ & $12: 03,16: 01$ & $11: 02,14: 54$ & 03:19, 05:03:01 & $105: 01^{2} 104: 01$ \\
\hline$\# 10$ & 01:01, 68:01 & $14,51: 01$ & 01:02, 08:02 & $11: 01$ & 03:01 & 04:01, 04:02 \\
\hline \#11 & $26: 01,29: 02$ & $35: 01,38: 01$ & 04:01, 12:03 & $13: 01,14: 54$ & 05:03:01, 06:03 & 04:01, 04:02 \\
\hline$\# 12$ & 03:01 & $07: 02,35: 01$ & 04:01, 07:02 & $11: 04,13: 01$ & 03:01, 06:03 & 04:01 \\
\hline$\# 13$ & 01, 02:01 & $14: 02,45: 01$ & $08: 02,16: 01$ & $11: 01,15: 01$ & 03:01, 06:02 & 04:01 \\
\hline \#14 & $02: 01,68$ & $35,44: 02$ & 04:01, 05:01 & 03:01, 11:04 & 02:01, 03:01 & 04:01, 04:02 \\
\hline \#15 & 02:01, 26:01 & $35: 02,55: 01$ & 01:02, 04:01 & $11: 01,11: 04$ & 03:01 & 04:02 \\
\hline$\# 16$ & $11: 01,24: 02$ & $35: 03,51: 01$ & $12: 03,15: 02$ & $11: 01,11: 04$ & 03:01 & 04:02 \\
\hline$\# 17$ & $32: 01,33: 01$ & $07: 02,14: 02$ & $07: 02,08: 02$ & 01:02, 15:01 & 05:01, 06:02 & $04: 01,04: 02$ \\
\hline
\end{tabular}

${ }^{1}$ PBMC were used to obtain primary $B$ cells and monocytes for MESF quantification of HLA-DR and DP expression in Figure 3.1. PBMC were selected to carry DPB1*04, either alone or in combination with DPB1*03:01 or DPB1*104:01. ${ }^{2}$ DPB1*105:01 is identical to DPB1*04:02 except for a single nucleotide substitution at codon 178 . 
Table S3.3 HLA typing of responder-stimulator cells used to obtain the alloreactive T cell effectors in this study.

\begin{tabular}{lccccccc}
\hline & \multicolumn{8}{c}{ HLA } \\
\cline { 2 - 7 } T cell effectors $^{1}$ & & $A^{*}$ & $B^{*}$ & C* & DRB1* & DQB1 \\
\hline C2-DK/DK-3 & R & $11: 01,24$ & $35: 01,13: 02$ & $04: 01,06: 02$ & $01: 01,16: 01$ & $05: 01,05: 02$ & $04: 02,10: 01$ \\
& S & $11: 01,01$ & $35: 01,13: 02$ & $04: 01,06: 02$ & $01: 01,16: 01$ & $05: 01,05: 02$ & $03: 01,04: 02$ \\
C11-DK/MN-3 & R & $11: 01,24: 02$ & $51: 01,35: 03$ & $15: 02,12: 03$ & $11: 01,11: 04$ & $03: 01$ & $04: 02$ \\
& S & $11: 01,24: 02$ & $51: 01,35: 08$ & $15: 02,04: 01$ & $11: 01,11: 04$ & $03: 01$ & $03: 01,02: 01$ \\
M3-VR/FV-3 & R & $02: 01,03: 01$ & $35: 01,58: 01$ & 02,03 & $03: 01,14: 01$ & $02: 01,05: 03$ & $04: 01$ \\
& S & $02: 01,03: 01$ & $35: 03,58: 01$ & $04: 01,03$ & $03: 01,14: 01$ & $02: 01,05: 03$ & $03: 01,04: 01$ \\
\hline
\end{tabular}

\footnotetext{
${ }^{1}$ Alloreactive $\mathrm{T}$ cell effectors were obtained by limiting dilution cloning (C2-DK/DK-3 and C11-DK/MN-3) or by repeated oligoclonal stimulation (M3-VR/FV-3) from MLR using Responder (R)-Stimulator (S) cells 8-10/10 high-resolution matched for HLA-A,B,C,DRB1,DQB1, but mismatched for HLA-DPB1.
} 


\section{Chapter 4}

\section{Allorecognition of HLA-DP by CD4+ T cells is affected by polymorphism in its alpha chain}

Nina Lauterbach*, Pietro Crivello*, Lotte Wieten, Laura Zito, Mathijs Groeneweg, Christien E.M. Voorter, Katharina Fleischhauer, Marcel G.J. Tilanus

Submitted 


\section{Abstract}

Alloreactivity to HLA-DP molecules, class II heterodimers of an oligomorphic alpha and a polymorphic beta chain, is increasingly being studied due to its relevance in clinical transplantation. We hypothesized that not only polymorphisms in the peptide binding groove encoded by exon 2 of HLA-DPB1, but also in other regions of the molecule and the alpha chain, could play a role in CD4+ $\mathrm{T}$ cell allorecognition. To test this possibility, we comparatively investigated $\mathrm{CD} 4+\mathrm{T}$ cell allorecognition, measured by upregulation of the activation marker CD137, against HLA-DPB1*13:01, ${ }^{*} 05: 01,{ }^{*} 03: 01, * 17: 01$ or their allele counter parts DPB1*107:01, *135:01, *104:01, *131:01, with identical exon 2 sequences but polymorphism in exons 1, 3 or 4, in the context of different HLA-DPA1 (DPA1) polymorphisms (DPA1*01:03 and *02:01). No significant differences in CD4+ T cell allorecognition levels could be demonstrated for any of the beyond exon 2 DPB1 variants studied. Interestingly, however, the mean fold change in CD4+ CD137+ cells was significantly higher when the target shared at least one DPA1 allele with the allogeneic stimulator, compared to a distinct DPA1 background (1.65 vs $0.23, p<0.005$ ). Structural homology modeling suggested specific amino acid residues in the alpha chain, in particular position 31, to impact CD4+ T cell allorecognition of HLA-DP. Our data argue against a significant role of beyond exon 2 DPB1 polymorphisms for T cell alloreactivity, but show relevance of DPA1 polymorphism in this mechanism. These new findings impact HLA matching strategies in unrelated stem cell transplantation. 


\section{Introduction}

HLA-DP represents one of the HLA class II molecules, that binds peptides derived from extracellular proteins and presents them on the surface of antigen presenting cells to CD4+ T cells. HLA-DP is expressed on the cell surface as a heterodimer consisting of an alpha chain encoded by the oligomorphic DPA1 gene and a beta chain encoded by the highly polymorphic DPB1 gene ${ }^{1}$. HLA-DP has been shown to play an important functional role in several immune-related conditions including autoimmunity ${ }^{2,3}$, beryllium disease ${ }^{4}$ and tumor and viral antigen recognition ${ }^{5-10}$. Accumulating evidence over recent years has also shown that alloreactivity to HLA-DP plays an important role in transplantation, both solid organs ${ }^{11-14}$ and hematopoietic stem cells (HSCT). In the latter setting, T cell alloreactivity against HLA-DP mismatches expressed by the patient cells has been shown to be associated with a higher risk to graft-versus-host-disease (GVHD) and disease relapse ${ }^{15-17}$. In contrast, HLA-DP mismatching was not associated with GVHD or survival in various other studies ${ }^{18-20}$. More recently, functional donorrecipient matching for alloreactive $T$ cell epitope groups has been shown to identify permissive or non-permissive mismatches associated with clinical risks after unrelated $\mathrm{HSCT}^{21-23}$.

Based on these results, interest in the mechanisms underlying $T$ cell alloreactivity to HLA-DP is rising. Most functional studies focused on exon 2 HLA-DPB1 (DPB1) gene polymorphism, encoding the peptide binding groove of the beta chain, as this is the region that is considered to play a dominant role in $T$ cell alloreactivity. A number of groups tried to identify immunogenic epitopes in the peptide binding groove of the beta chain to unravel HLA-DP immunogenicity ${ }^{24-26}$. These studies describe a crucial role for various amino acid residues in the peptide binding groove in T cell allorecognition of the DP molecule, nevertheless $T$ cell alloreactivity to HLA-DP cannot be pointed to these residues.

Knowledge about the functional relevance of polymorphism beyond DPB1 exon 2 is scarce. We previously described, in addition to the known DPB1 polymorphism in exon 2 , polymorphism in the exons $1,3,4$ and $5^{27}$. However, it is currently unknown if these polymorphisms influence $\mathrm{T}$ cell allorecognition.

The $T$ cell receptor binds to both the beta- and alpha chain of the HLA-DP molecule in a peptide dependent manner ${ }^{28,29}$. The HLA-DP alpha chain shows limited polymorphism compared to the beta chain, but still the HLA-DPA1 (DPA1) alleles encode 19 different cell surface proteins ${ }^{30}$. Since DPA1 is in strong linkage disequilibrium (LD) with DPB1 ${ }^{31,32}$, DPA1 is rarely considered in functional or clinical studies of HLA-DP. Gaston et al. were the first to describe an influence of polymorphism in the HLA-DP alpha chain on recognition of a heat shock protein-derived peptide by HLA-DP restricted T cell clones and suggested an important role for the DPA1 amino acid at position 31 in peptide binding affinity ${ }^{33}$. Also Reche and Reinherz indicate a role for polymorphic residues of HLA-DPA1 in TCR and peptide binding ${ }^{34}$. In HLA-matched unrelated HSCT, donor-recipient DPA1 but not DPB1 disparity has been suggested to be associated with 
reduced survival and shorter relapse-free survival in a single center study ${ }^{35}$, although this was not confirmed by others ${ }^{15,18,19}$. These findings suggest that the role of the HLA-DP alpha chain on $T$ cell allorecognition needs further attention for a better understanding of HLA-DP immunogenicity in transplantation.

In the present study, we hypothesized that allorecognition of HLA-DP by CD4+ T cells could be shaped by polymorphism in the regions beyond the peptide binding groove of the beta chain, and/or by polymorphism in the alpha chain. The study addresses two questions: First, do targets with DPB1 polymorphism in exons 1, 3 or 4 but identical exon 2 sequences have an impact on HLA-DP allorecognition by CD4+ T cells and second, does polymorphism in the alpha chain influence CD4+ $T$ cell allorecognition of HLA-DP? In order to address these questions, we undertook a functional analysis of T cells alloreactive to HLA-DP antigens formed by beta-alpha chain heterodimers encoded by DPB1 alleles with beyond exon 2 variability and the two most frequent DPA1 allele variants, DPA1*01:03 and DPA1*02:01, respectively.

\section{Materials and methods}

\subsection{Cells and HLA-DP typing}

Epstein-Bar virus transformed B-cell lymphoblastoid cell lines (BLCLs) were either purchased from the European Collection for Animal Cell Cultures (ECACC) or locally established. Responder (R) and Stimulator (S) cells for mixed lymphocyte reactions (MLR) were obtained from healthy individuals selected as potential donors for unrelated hematopoietic stem cell transplantation for patients at the San Raffaele Scientific Institute in Milan. HLA-DPA1 typing was obtained by PCR-Sequence-Specific Oligonucleotide (SSO) using the luminex technology ${ }^{36}$. High resolution DPB1 typing of $\mathrm{R} / \mathrm{S}$ donor pairs was performed by PCR-Sequence Specific Priming (PCR-SSP) using the Olerup $^{\mathrm{TM}}$ kit (Olerup $\mathrm{GmbH}$, Vienna, Austria), according to the manufacturer's recommendations. It should be noted that this method allowed discrimination of the outside exon 2 polymorphisms studied in this work. High resolution HLA-DPB1 typing of target BLCLs used for functional testing of outside exon 2 DPB1 variants was performed by sequence-based typing as previously described ${ }^{27}$. The DPA1 and DPB1 typing results of the cells are shown in Tables 4.1 and 4.2.

\subsection{Monoclonal antibodies and flow cytometry}

Monoclonal antibodies (mAb) anti-HLA-DR (L243 unconjugated, Biolegend, Uithoorn, The Netherlands) and anti-HLA-DP (B7/21 unconjugated, kindly provided by Sir W. Bodmer, London, UK) were used as blocking mAbs in functional assays. The mAb antiNGFR (ME20.4 unconjugated, Miltenyi Biotec Bergisch Gladbach, Germany) was used to analyze $\triangle$ LNGFR expression in transduced cell lines, as the truncated human Low 
affinity Nerve Growth Factor Receptor was incorporated in the vector as marker to monitor NGFR surface expression and transduction efficiency. The unconjugated human mAb anti-HLA-DP directed against DEAV(84-87) motif (TL-3B6), kindly provided by Dr. Arend Mulder, was used to measure transgenic HLA-DP expression in the transduced cell lines. To detect this human IgG specific for HLA-DP, a FITC-conjugated AffiniPure $F\left(a b^{\prime}\right) 2$ fragment of goat anti-Human IgG antibody specific for the Fc-gamma fragment was used (Jackson ImmunoResearch, West-Grove, USA). The mAbs anti-CD4 (RPA-T4, allophycocyanin (APC)-conjugated, Becton Dickinson (BD), Milan, Italy) and anti-CD137 (4B4-1, phycoerythrin-conjugated (PE), BD) were used to measure CD4+ T cell activation as described ${ }^{37,38}$. All cytofluorimetric studies were performed using FACSCanto II and FACSDiva software (BD) and were analyzed using the FCS Express 3.0 software (De Novo Software, Los Angeles CA, USA).

Table 4.1 HLA-DPB1 and-DPA1 typing of BLCLs used in this study.

\begin{tabular}{lcccc}
\hline BLCL $^{\text {a }}$ & DPB1 & DPA1 & DRB1 & DQB1 $^{*}$ \\
\hline MGAR $^{*}$ & $04: 01$ & $01: 03$ & $15: 01$ & $06: 02$ \\
MGAR03 $^{\text {a }}$ & $04: 01,{ }^{*} 03: 01^{b}$ & $01: 03$ & $15: 01$ & $06: 02$ \\
MGAR104 $^{\text {a }}$ & $04: 01,{ }^{*} 104: 01^{b}$ & $01: 03$ & $15: 01$ & $06: 02$ \\
MGAR17 & $04: 01,{ }^{*} 17: 01^{b}$ & $01: 03$ & $15: 01$ & $06: 02$ \\
MGAR131 & $04: 01,{ }^{*} 131: 01^{b}$ & $01: 03$ & $15: 01$ & $06: 02$ \\
VAVY & $01: 01$ & $02: 01$ & $03: 01$ & $02: 01$ \\
VAVY03 & $01: 01,{ }^{*} 03: 01^{b}$ & $02: 01$ & $03: 01$ & $02: 01$ \\
VAVY104 & $01: 01,{ }^{*} 104: 01^{b}$ & $02: 01$ & $03: 01$ & $02: 01$ \\
VAVY17 & $01: 01,{ }^{*} 17: 01^{b}$ & $02: 01$ & $03: 01$ & $02: 01$ \\
VAVY131 & $01: 01,{ }^{*} 131: 01^{b}$ & $02: 01$ & $03: 01$ & $02: 01$ \\
15745DP13 & $13: 01$ & $02: 01$ & $01: 01$ & $05: 01$ \\
15748DP107 & $107: 01$ & $04: 01$ & $09: 01$ & $03: 03$ \\
15716DP05 & $05: 01$ & $02: 02$ & $14: 05,15: 01$ & $05: 03,06: 01$ \\
30400DP135 & $135: 01$ & $02: 02$ & $11: 05,15: 02$ & $05: 02,06: 02$ \\
\hline
\end{tabular}

${ }^{\mathrm{a}}$ Transduced BLCL described in ${ }^{41}$. ${ }^{\mathrm{b}}$ Allele in italic was introduced by LV-mediated transduction.

Table 4.2 HLA-DRB1, -DQB1, -DPA1 and-DPB1 typing of R-S cells ${ }^{b}$.

\begin{tabular}{|c|c|c|c|c|c|}
\hline \multirow[b]{2}{*}{ T cell Effector } & \multicolumn{5}{|c|}{ HLA } \\
\hline & & DRB1* & DQB1* & DPA1* & DPB1* \\
\hline \multirow[t]{2}{*}{ M8-DK4/DK5-13 } & $\mathrm{R}$ & $15: 01,16: 01$ & $06: 02,05: 02$ & 01:03 & 04:01, 03:01 \\
\hline & $\mathrm{S}$ & $15: 01,16: 01$ & $06: 02,05: 02$ & 01:03, 02:01 & $04: 01,13: 01$ \\
\hline \multirow[t]{2}{*}{ M7-NM1/NM2-5 } & $\mathrm{R}$ & 04:02, 07:01 & $03: 02,02: 02$ & 01:03 & 03:01, 04:01 \\
\hline & $\mathrm{S}$ & $04: 02,07: 01$ & $03: 02,02: 02$ & $01: 03,02: 01$ & $06: 01,05: 01$ \\
\hline \multirow[t]{2}{*}{ M4-DE/PD-17 } & $\mathrm{R}$ & 07:01, 15:01 & $02: 02,06: 02$ & 01:03 & 02:01, 04:01 \\
\hline & $\mathrm{S}$ & 07:01, 15:01 & $02: 02,06: 02$ & 01:03, 02:01 & 03:01, 17:01 \\
\hline \multirow[t]{2}{*}{$C 2-D K / D K-3^{a}$} & $\mathrm{R}$ & 01:01, 16:01 & $05: 01,05: 02$ & 01:03 & $04: 02,10: 01$ \\
\hline & $\mathrm{S}$ & 01:01, 16:01 & 05:01, 05:02 & 01:03 & 04:02, 03:01 \\
\hline \multirow[t]{2}{*}{$\mathrm{C} 11-\mathrm{DK} / \mathrm{MN}-3^{\mathrm{a}}$} & $\mathrm{R}$ & $11: 01,11: 04$ & 03:01 & $01: 03,02: 01$ & $04: 02$ \\
\hline & $\mathrm{S}$ & $11: 01,11: 04$ & 03:01 & $01: 03$ & 02:01, 03:01 \\
\hline
\end{tabular}

\footnotetext{
${ }^{\mathrm{a}} \mathrm{T}$ cell effector described $\mathrm{in}^{41}$. ${ }^{\mathrm{b}} \mathrm{R}$ cells= responder cells, $\mathrm{S}$ cells= stimulator cells.
} 


\section{3. $\mathrm{DPB} 1$ transduction via lentiviral vectors into BLCLs}

Lentiviral vector (LV) production and BLCL transduction of DPB1*03:01 and *104:01 has been described elsewhere ${ }^{39}$. LV-mediated gene transfer of DPB1*17:01 and *131:01 was performed accordingly. Briefly, we used a bidirectional promoter LV vector, kindly provided by Professor Naldini, Milan, Italy ${ }^{40}$, with DPB1 expression under the control of the human phosphoglycerate kinase (hPGK) promoter and the truncated human Low affinity Nerve Growth Factor Receptor ( $\triangle$ LNGFR) reporter under a minimal core promoter derived from CMV fused in the opposite direction to hPGK promoter (see Figure 4.1A). Thanks to this bidirectional promoter vector, we were able to obtain coordinated expression of DPB1 and $\triangle$ LNGFR transgenes ${ }^{39,41}$. Target cells were LV-transduced using previously described protocols ${ }^{40}$ and purified by magnetic bead selection (Myltenyi Biotec) for the $\triangle$ LNGFR reporter.

\subsection{Isolation and maintenance of T lymphocytes alloreactive to HLA-DP}

T cell effectors alloreactive to HLA-DP3 have been described elsewhere ${ }^{41}$. For the isolation of T cell effectors, alloreactive to HLA-DP13, 5, 17 and 3, peripheral blood mononuclear cells (PBMCs) from unrelated donor pairs completely matched for HLA-DRB1 and -DQB1 alleles were used as R and S cells in classical 1-way MLRs. Briefly, R-PBMC were stimulated twice with irradiated S-PBMC at a 1:1 ratio in the presence of $150 \mathrm{UI} / \mathrm{ml}$ interleukin-2 (IL-2; Novartis, Varese, Italy). Alloreactive T cells were maintained in the presence of $300 \mathrm{UI} / \mathrm{ml} \mathrm{IL-2,} \mathrm{irradiated} \mathrm{S-BLCL} \mathrm{and} \mathrm{third} \mathrm{party} \mathrm{feeder}$ PBMC before or after limiting dilution cloning by previously described protocols ${ }^{39}$.

\subsection{Functional testing of outside exon 2 DPB1 variants}

Alloreactivity of T cell effectors was mainly assessed by quantification of cell surface expression of the activation marker $\mathrm{CD} 137^{37,38}$, which was previously used to study $\mathrm{CD} 4+\mathrm{T}$ responses by our group and others ${ }^{41-44}$. T cells were incubated with target $\mathrm{BLCL}$ at a $1.5: 1$ ratio for 24 hours at $37^{\circ} \mathrm{C}$. Cells were thereafter stained with fluorochromelabelled anti-CD4 and anti-CD137 mAbs. The percentage of CD4+/CD137+ T cells was determined by cytofluorimetric analysis and the response to each target BLCL was calculated as fold change $\mathrm{CD} 4+\mathrm{CD} 137+$ percentage relative to the allogeneic stimulator $\mathrm{BLCL}$, according to the following formula: (\% CD4+/CD137+ $\mathrm{T}$ cells $\left.\mathrm{s}_{[\mathrm{Target}} \mathrm{BLCL}\right]^{-}$ $\% \mathrm{CD}_{+}+\mathrm{CD} 137+\mathrm{T}$ cells $\left._{[\mathrm{R}-\mathrm{BLCL}]}\right) /\left(\%\right.$ CD4+/CD137+ $\mathrm{T}$ cells $\mathrm{SS}_{[\mathrm{SLCL}]^{-}} \% \mathrm{CD4+/CD137+}$ $T$ cells $\left.S_{[R-B L C L}\right)$. Other functional assays used in this work and described in details elsewhere were: CD107a degranulation assay ${ }^{41}$, chromium release cytotoxic assay ${ }^{45}$, and g-IFN ELISpot assay ${ }^{46,47}$. To validate whether the CD137 assay can be used to measure CD4+ $\mathrm{T}$ cell responses, the CD137 assay was compared to three other functional assays as indicated in Table 4.3. Responses from two CD4+ T cell clones showed comparable results between the CD137 assay, CD107a degranulation assay, g-IFN Elispot and chromium release cytotoxic assay. 
For $\mathrm{mAb}$ inhibition studies, target $\mathrm{BLCL}$ were pre-incubated for 30 minutes at $4^{\circ} \mathrm{C}$ with the relevant unconjugated $\mathrm{mAb}$ at a final concentration of $30 \mu \mathrm{g} / \mathrm{ml}$, before addition of T cell effectors.

Table 4.3 T cell response to autologous ( $R-B L C L)$ and allogeneic (S-BLCL) assessed by different functional assays.

\begin{tabular}{|c|c|c|c|c|c|}
\hline \multirow[b]{2}{*}{ Functional Assay ${ }^{a}$} & \multirow[b]{2}{*}{$\mathrm{N}$ (Replicates) } & \multicolumn{2}{|c|}{ C2-DK/DK-3 } & \multicolumn{2}{|c|}{ C11-DK/MN-3 } \\
\hline & & $\mathrm{R}-\mathrm{BLCL}$ & S-BLCL & $\mathrm{R}-\mathrm{BLCL}$ & S-BLCL \\
\hline $\begin{array}{l}\text { CD137 Upregulation } \\
\left(\text { Mean } \pm \text { SD of } \% \text { CD } 4^{+} \text {CD } 137^{+} \text {) }\right.\end{array}$ & $3(1)$ & $0.00 \pm 0.00$ & $17.43 \pm 2.90$ & $0.00 \pm 0.00$ & $3.51 \pm 2.03$ \\
\hline $\begin{array}{l}\text { CD107a Degranulation } \\
\left(\text { Mean } \pm \text { SD of } \% \text { CD4 } 4^{+} \text {CD107a }{ }^{+}\right)\end{array}$ & $3(1)$ & $2.30 \pm 0.74$ & $50.20 \pm 16.23$ & $1.4 \pm 0.8$ & $21.04 \pm 6.05$ \\
\hline $\begin{array}{l}\text { gIFN ELISpot } \\
\text { (Mean } \pm \text { SD of IFN- } \gamma \text { spots per well) }\end{array}$ & $1(2)$ & ND & ND & $1 \pm 0$ & $172 \pm 17$ \\
\hline $\begin{array}{l}\text { Cr Release Cytotoxic assay } \\
\text { (\% specific lysis) }\end{array}$ & $1(1)$ & 2 & 58 & 4 & 5 \\
\hline
\end{tabular}

$\mathrm{ND}=$ not determined. ${ }^{\mathrm{a}} \mathrm{T}$ cell effectors C2-DK/DK-3 and C11-DK/MN-3 were incubated with autologous R- or allogeneic S-BLCLs and the percentage of activated cells was determined by FACS staining for the activation marker CD137 or CD107a, or the number of IFN- $p$ secreting cells was determined by ELISPOT, or percentage of specific lysis was examined by $\mathrm{Cr}$ release assay.

\subsection{Homology modeling of DPA1/DPB1 heterodimers}

The full length sequences of the DPA1 alleles (Table 4.4) were aligned and modeled along with the DPB1 alleles (Table 4.5) analyzed in this study. The computer model was based on the X-ray crystal structure of HLA-DP2 (RCSB Protein Data Bank (PDB):3(qz)) and missing residues in the DP complex were reconstructed by homology modeling using SWISS-PDBVIEWER 4.0.1 ${ }^{48}$. Both variant structures were energy minimized and underwent 10 ps molecular dynamics (MD) simulations with a distantdependent dielectric constant. All parameters were set to default for the minimization and MD simulations. The HLA-DP computer models display the polymorphic residues in the peptide binding groove of the alpha chain which are most likely to be in a position to impact TCR interaction or peptide binding.

\subsection{Statistical analyses}

All results are expressed as mean +/- standard error of the mean (SEM) of at least three independent experiments. Comparative analyses were performed by the unpaired t-test for expression analyses or paired t-test for the functional analyses $(p<0.05$ is considered significant). All statistical analyses were carried out using the GraphPad Prism 5.0 (GraphPad Software, La Jolla CA, USA). 
Table 4.4 Amino acid polymorphism encoded by exon 2 of DPA1 alleles analyzed in this study.

\begin{tabular}{lllllllll}
\hline DPA1*a & Exon 2 & & & & & & & \\
& 11 & 18 & 28 & 31 & 50 & 72 & 73 & 83 \\
\hline $01: 03$ & $\mathrm{~A}$ & $\mathrm{P}$ & $\mathrm{E}$ & $\mathrm{M}$ & $\mathrm{Q}$ & $\mathrm{T}$ & $\mathrm{L}$ & $\mathrm{T}$ \\
$02: 01$ & - & - & - & $\mathrm{Q}$ & $\mathrm{R}$ & - & - & $\mathrm{A}$ \\
$02: 02$ & $\mathrm{M}$ & - & - & $\mathrm{Q}$ & $\mathrm{R}$ & - & - & $\mathrm{A}$ \\
$04: 01$ & - & $\mathrm{T}$ & $\mathrm{D}$ & - & $\mathrm{R}$ & $\mathrm{I}$ & $\mathrm{A}$ & $\mathrm{A}$ \\
\hline
\end{tabular}

a Dashes indicate amino acid residues identical to those encoded by DPA1*01:03 at the corresponding position.

Table 4.5 Amino acid polymorphism encoded by exon 1-4 of DPB1 alleles analyzed in this study.

\begin{tabular}{|c|c|c|c|c|c|c|c|c|c|c|c|}
\hline \multirow[t]{2}{*}{$\mathrm{DPB} *^{\mathrm{a}}$} & \multirow{2}{*}{$\begin{array}{c}\text { Exon } 1 \\
-14 \\
\end{array}$} & \multicolumn{6}{|c|}{ Exon 2} & \multicolumn{2}{|c|}{ Exon 3} & \multicolumn{2}{|c|}{ Exon 4} \\
\hline & & 8-11 & $35-36$ & $55-57$ & $65-69$ & 76 & $84-87$ & 96 & 170 & 194 & 205 \\
\hline 13:01 & $\mathrm{T}$ & VYQL & YA & $\mathrm{AAE}$ & ILEEE & 1 & DEAV & $\mathrm{K}$ & 1 & $\mathrm{R}$ & $\mathrm{V}$ \\
\hline 107:01 & $M$ & - & - & - & - & - & - & - & - & - & - \\
\hline 05:01 & $\mathrm{T}$ & LFQG & LV & EAE & ILEEK & $M$ & DEAV & $\mathrm{K}$ & I & $\mathrm{R}$ & $M$ \\
\hline 135:01 & - & - & - & - & - & - & - & - & - & - & $\mathbf{v}$ \\
\hline 03:01 & $\mathrm{T}$ & VYQL & $\mathrm{FV}$ & DED & LLEEK & V & DEAV & $\mathrm{K}$ & I & $\mathrm{R}$ & V \\
\hline 104:01 & - & - & - & - & - & - & - & - & - & - & M \\
\hline 17:01 & $\mathrm{T}$ & VHQL & FV & DED & ILEEE & $M$ & DEAV & $\mathrm{R}$ & $\mathrm{T}$ & $\mathrm{R}$ & V \\
\hline 131:01 & - & - & - & - & - & - & - & $\mathrm{K}$ & I & $\mathbf{Q}$ & - \\
\hline
\end{tabular}

${ }^{a}$ Each horizontal block displays two DPB1 alleles with identical sequences in exon 2 however differences in exon 1, 3, 4 or 5 (in bold). - Identity with the original sequence. Amino acids in red represent the differences between the two alleles in one block.

\section{Results}

\subsection{DPB1 polymorphism beyond exon 2 has no apparent effect on CD4+ T cell allorecognition}

To study the fundamental mechanism of CD4+ T cell alloreactivity to HLA-DP, five different CD4+ T cell effectors alloreactive to DPB1*13:01, *05:01, *03:01 and *17:01, respectively, were used (Table 4.2). BLCLs expressing DPB1*13:01, *05:01, *03:01, or *17:01 or their allele counterparts with identical exon 2 sequences but differences in exons 1,3 or 4 (DPB1*107:01, *135:01, *104:01, *131:01) were used as targets to determine the relevance of polymorphisms beyond exon 2 in allorecognition by our established CD4+ effector T cells.

The BLCLs used as targets for the CD4+ effector T cells expressed the DPB1 allele either endogenously or after LV-mediated gene transfer (Figure 4.1A). To determine transduction efficiency of the transduced cell lines, NGFR expression was analyzed with an anti-NGFR mAb. This revealed similar levels of transgene expression by almost all cell lines except for MGAR03 which showed significantly higher NGFR expression compared to MGAR104 (Figure 4.1B). Furthermore, to assure that the transduced cells 
which were positive for NGFR also expressed the transgenic HLA-DP molecule, we used a monoclonal antibody directed against the DEAV motif of the transduced DP molecule, which is absent in the endogenous DPB1 of MGAR. With this antibody the presence of transduced DP next to NGFR expression in the MGAR cell lines was demonstrated after transduction (Figure 4.1C). For the VAVY cell line this could not be tested, since the endogenous DPB1 of this BLCL bears the DEAV motif. However, for this cell line comparable NGFR expression levels to MGAR were reached (Figure 4.1B), indicating comparable transduction efficiency. Based on the comparable expression of NGFR and DP in MGAR, and the NGFR expression in VAVY (Figure 4.1), it is reasonable to assume that also transduced VAVY cells express sufficient amounts of transgenic DPB1 to be recognized.

Allospecificity of the T cell effectors was studied by analysis of the activation marker CD137 upon co-culture with the HLA-DP expressing target BLCLs. Prior to investigating our research questions, we performed experiments to confirm the specificity of the effector T cells. To show that activation of the T cell effectors was mainly HLA-DPspecific, target BLCL were pre-incubated with mAbs against HLA-DP or HLA-DR. For all five $T$ cell effector lines, incubation with the mAb against HLA-DP completely blocked recognition of allogeneic stimulator $B L C L$, as evidenced by a decrease in the percentage of CD137 positive CD4+ T cells to the level of the autologous R-BLCL (Table 4.6). Incubation of the allogeneic S-BLCL with anti-DR resulted in a decrease in the percentage of CD137+ CD4+ T cells when compared to stimulation with the S-BLCL without anti-DR. However, unlike anti-DP, there was no blockage of recognition to the level of the autologous R-BLCL. To illustrate that the effector T cells were directed against a specific DPB1 allele, the effector T cells were stimulated with untransduced cell lines, with cell lines transduced with an irrelevant DPB1 allele, with the positive allogeneic control or with cell lines transduced with a relevant DPB1 allele. Our results show that both the $T$ cell clones C2-DK/DK-3 (Figure 4.2A+B) and C11-DK/MN-3 (Figure 4.2B) are unresponsive against MGAR untransduced and MGAR transduced with HLA-DPB1*01:01, the irrelevant DPB1 allele. However, stimulation of these T cell clones with the allogeneic positive control and MGAR transduced with HLA-DPB1*03:01, the relevant DPB1 allele, resulted in a significant increase in the percentage of CD137+ CD4+ T cells. Although not significant, also effector T cell M4-DE/PD-17 showed the same pattern with an increase in reactivity when stimulated with the allogeneic positive control and VAVY transduced with HLA-DPB1*17:01, while having no increase in the percentage of CD137+ CD4+ T cells with VAVY untransduced and VAVY transduced with HLA-DPB1*04:01, the irrelevant DPB1 allele (Figure 4.2C). 
A

\section{Bidirectional promotor Ientiviral vector}

$\mathbf{B}$

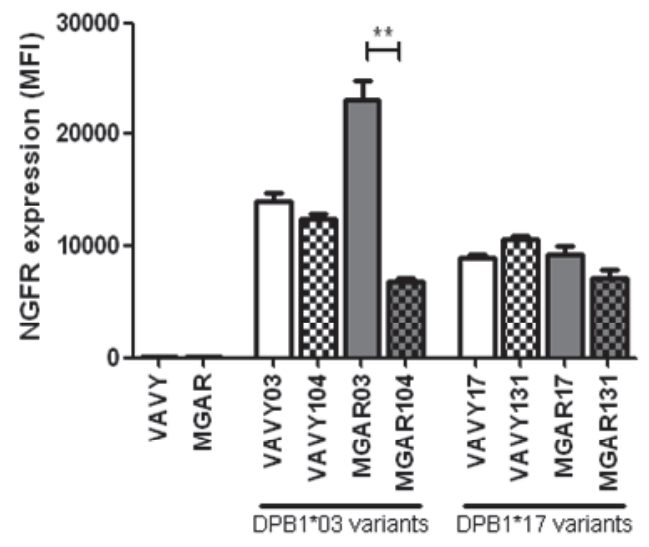

C
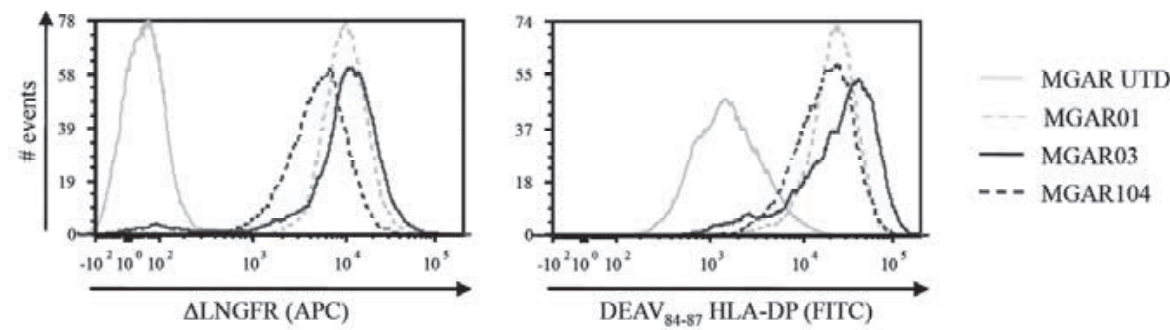

Figure 4.1 LV-mediated gene transfer of HLA-DPB1 into BLCL and transgenic HLA-DP expression in transduced cell lines (A) LV construct used to drive coordinate expression of HLA-DPB1 and $\triangle$ LNGFR under the control of a bidirectional promoter derived by fusion in opposite directions of hPGK promoter and a minimal core of CMV promoter (adapted from ref. ${ }^{40}$. (B) Cell surface expression levels of the $\triangle N G F R$ reporter on BLCL VAVY and MGAR, homozygous for endogenous DPB1*01:01 and DPA1*02:01 (white bars) or DPB1*04:01 and DPA1*01:03 (grey bars), respectively, before or after transduction with the relevant WT DPB1 (filled bars) or its beyond exon 2 variant (dotted bars). Data are presented with SEM of at least three independent experiments. $* * p=<0.001$. (C) Cell surface expression of the LV-encoded $\triangle L N G F R$ reporter (left panel) and cell surface expression of HLA-DP with use of mAb specific for DEAV(84-87) on MGAR UTD, MGAR01, MGAR03 or MGAR104 (right panel). 
A

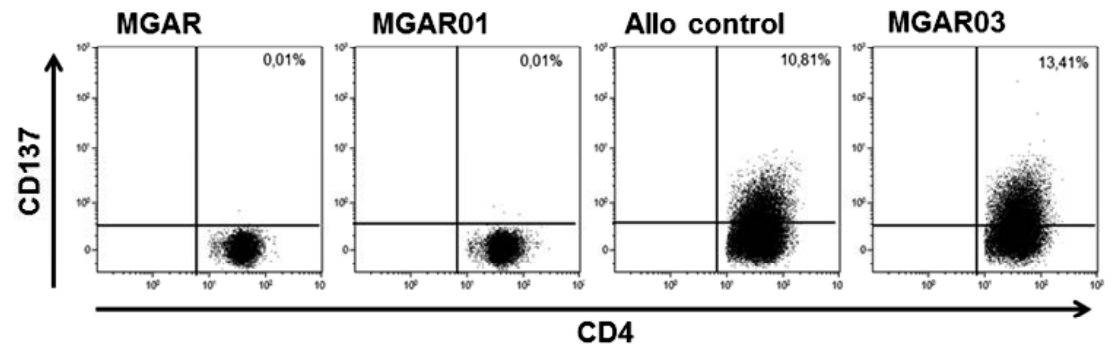

B

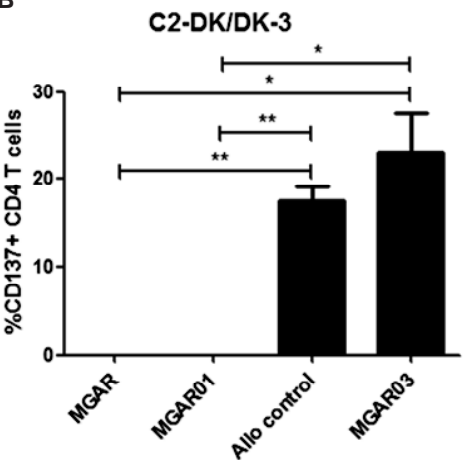

C11-DK/MN-3

C
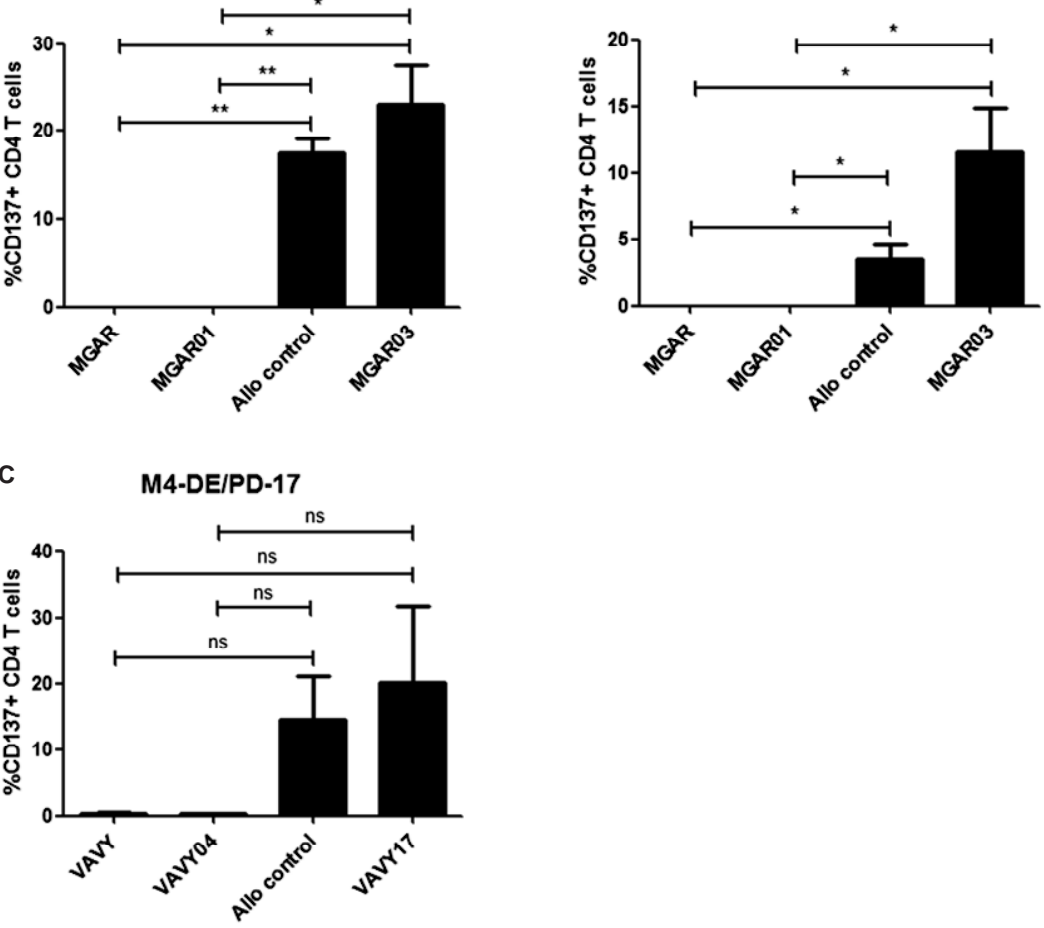

Figure 4.2 Upregulation of the activation marker CD137 on CD4+ T cells after stimulation with $B L C L$ expressing the relevant allogeneic HLA-DPB1 allele. $T$ cell effectors C2-DK/DK-3, C11-DK/MN-3 and M4-DE/PD-17 were incubated overnight with untransduced or transduced MGAR, with untransduced or transduced VAVY or with the allogeneic stimulator (allo control). After staining with mAbs for CD4 (FITC) and CD137 (PE), the percentage of activated CD4+ CD137+ T cells was determined on gated lymphocytes. Fold change CD4+CD137+ percentage, used as measure in further experiments, was calculated as described in Materials and Methods. (A) FACS plots representing percentages of CD4+ CD137+ cells in response to MGAR, MGAR01, Allo control or MGAR03; (B) T cell effector C2-DK/DK-3 (left panel) or C11-DK/MN-3 (right panel) against MGAR, MGAR01, allogeneic control and MGAR03; (C) T cell effector M4-DE/PD-17 against VAVY, VAVY04, allo control and VAVY 17. Data are presented with SEM of three independent experiments. ${ }^{*} p=<0.05$ $* * p=<0.01$ 
Incubation of target BLCLs with the CD4+ effector $\mathrm{T}$ cells revealed that DPB1 polymorphism beyond exon 2 by itself appeared not to have a significant impact on allorecognition (Figure 4.3A-D). In particular, for the effector T cell C2-DK/MN-3 similar recognition levels, expressed as fold change in $\mathrm{CD} 4+\mathrm{CD} 137+$ percentage relative to the allogeneic stimulator control, were observed upon incubation with BLCL VAVYO3 and VAVY104 and MGAR03 and MGAR104 (Figure 4.3A), and with T cell effector M7-NM1/NM2-5 similar recognition levels were found upon incubation with 15716DP05 and 30400DP135 (Figure 4.3B). Both DPB1*03:01/104:01 and DPB1*05:01/135:01 differ by a single amino acid encoded by exon 4 (Table 4.5), which seems to have a limited functional impact thereby confirming our previous results ${ }^{41}$. Likewise, the polymorphisms in exons 3 and 4 present in the allelic variants DPB1*17:01/131:01 did not result in a significant difference in the recognition levels of transduced MGAR BLCL by $\mathrm{T}$ cell effector M4-DE/PD-17 (Figure 4.3C). Interestingly however, the same DPB1 allele variant pair, when transduced into VAVY BLCL, did show a significant difference in the levels of $T$ cell allorecognition (Figure 4.3C). Finally, a significant difference in recognition level by $T$ cell effector M8-DK4/DK5-13 was observed between BLCL15745DP13 and 15748DP107 (Figure 4.3D). These two BLCL carry DPB1 alleles with identical sequences except for a single amino acid difference in exon 1 encoding the leader peptide which is not expressed in the mature protein and thus is unlikely to be responsible for the difference in allorecognition.

\subsection{CD4+ T cell allorecognition of HLA-DP is significantly affected by DPA1 polymorphism}

Allospecificity of the effector T cells used in our study had been initially defined based on their ability to recognize amino acid differences in the beta chain of the allogeneic HLA-DP molecule, without including polymorphism in the alpha chain. We characterized the DPA1 background of our BLCLs and of the allogeneic stimulator controls (Table 4.1 and 4.2). Interestingly, we identified significant differences in allorecognition by $\mathrm{T}$ cell effector C2-DK/MN-3 and M4-DE/PD-17 of identical DPB1 constructs according to whether they were expressed by MGAR or VAVY BLCL, homozygous for DPA $1 * 01: 03$ and $* 02: 01$, respectively (Figure $4.3 A+C$ ). In particular, for $T$ cell effector $\mathrm{C2}-\mathrm{DK} / \mathrm{MN}-3$, fold change in CD4+CD137+ percentage relative to the allogeneic stimulator control in response to DPB1*03:01/104:01 was significantly higher in association with DPA1*01:03 on MGAR compared to DPA1*02:01 on VAVY BLCL (1.28 vs. 0.21, $p<0.05$; Figure 4.3A). For T cell effector M4-DE/PD-17 opposite results were obtained, since DPB1*17:01/131:01 were, although not significant, better recognized in association with DPA1*02:01 on VAVY compared to DPA1*01:03 on MGAR BLCL (0.82 vs. 0.28, $p=0.09$; Figure $4.3 C$ ). Moreover, the significant differences in allorecognition of beyond exon 2 DPB1 variants were observed only in the presence of a specific DPA1 allele. For T cell effector M4-DE/PD-17 significant differences were found between DPB1*17:01 and DPB1*131:01 when expressed with DPA1*02:01 (1.07 
(VAVY17) vs. 0.57 (VAVY131), P<0.01) but not with DPA1*01:03 (0.35 (MGAR17) vs. 0.20 (MGAR131); $p=$ n.s.) (Figure 4.3C). For T cell effector M8-DK4/DK5-13 significant differences were found between DPB1*13:01 and DPB1*107:01 in BLCLs carrying different DPA1 alleles (1.23 vs. 0.62; $p<0.05$; Figure 4.3D).

A

C2-DK/MN-3

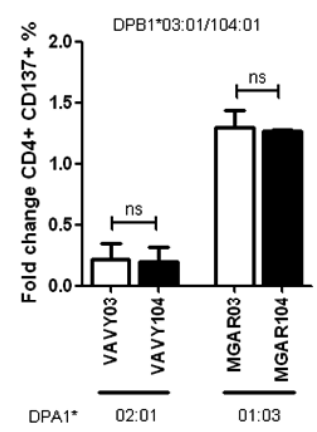

C

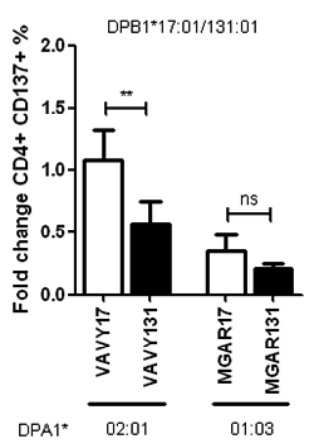

B $\quad$ M7-NM1/NM2-5

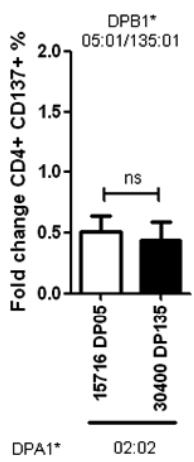

D

M8-DK4/DK5-13

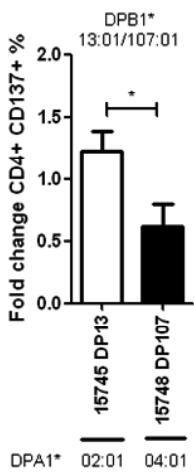

Figure 4.3 Polymorphisms beyond exon 2 of DPB1 have no significant influence on CD4+ T cell allorecognition unless in combination with DPA1 polymorphism. Shown is the Fold Change in CD4+CD137+ percentage, relative to the allogeneic stimulator control, in response to BLCLs expressing the relevant allogeneic DPB1 (white bars) or its beyond exon 2 variant (black bars). The mean percentage of $\mathrm{CD} 4+\mathrm{CD} 137+\mathrm{T}$ cells in response to allogeneic/autologous stimulator control is indicated after the name of each T cell effector. (A) HLA-DP3 (C2-DK/MN-3; 17.43/0.00); (B) DP5 (M7-NM1/NM2-5; 41.82/0.16); (C) DP17 (M4-DE/PD-17; 14.48/0.36); (D) DP13 (M8-DK4/DK5-13; 4.81/0.09). The compared DPB1 alleles are indicated on the top of each graph. For each pair of BLCLs, typing of endogenous DPA1 is indicated at the bottom of the panel. Data are presented with SEM of at least three independent experiments. ns: not significant. $* p=<0.05 * * p=<0.01$. 
To study the effect of DPA1 polymorphism, we focused on all T cell responses upon incubation with $\mathrm{BCL}$ targets sharing at least one DPA1 allele with the original stimulator in comparison to $T$ cell responses with BLCLs sharing no DPA1 allele. This revealed that recognition of allogeneic HLA-DP was significantly better for target BLCLs that shared at least one DPA1 allele with the allogeneic stimulator, compared to a target BLCL carrying a distinct DPA1 background; mean fold change in the percentage of CD137 expressing CD4+ T cells of 1.65 vs. 0.23 , respectively ( $p<0.005$; Figure 4.4 ).

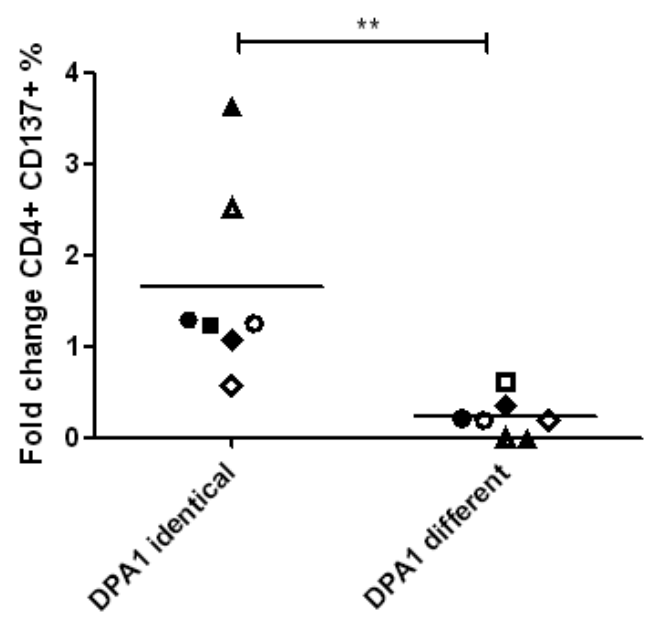

Figure 4.4 The strength of the alloreactive T cell response to HLA-DP is modulated by whether or not the DPA1 of the target is identical or different when compared to the DPA1 of the original stimulator cell. Shown is the Fold Change in CD4+CD137+ percentage, relative to the allogeneic stimulator control, of individual T cell effectors in response to BLCL targets carrying a DP-alpha chain that was identical or different when compared to the original stimulator BLCL. Each dot represents data from at least three independent experiments, with representation of the overall mean. The mean percentage of $C D 4+C D 137+T$ cells in response to allogeneic/ autologous stimulator controls indicated after the name of each $T$ cell effector. $T$ cell effectors were C2-DK/MN-3 (17.43/0.00) in response to DPB1*03:01 (closed circles) or DPB1*104:01 (open circles), C11-DK/MN-3 (3.51/0.01) in response to DPB1*03:01 (closed triangles) or DPB1*104:01 (open triangles), M4-DE/PD-17 (14.48/0.36) in response to DPB1*17:01 (closed diamonds) or DPB1*131:01 (open diamonds), and M8-DK4/DK5-13 $(4.81 / 0.09)$ in response to DPB1*13:01 (closed squares) or DPB1*107:01 (open squares). $* *=p<0.005$. 
Table 4.6 Allospecificity of effector T cells used in this study.

\begin{tabular}{lcccc}
\hline T cell effector & \multicolumn{3}{c}{ Mean \% of activated CD4+/CD137+ T cells (Range) } \\
\cline { 2 - 5 } & R-BLCL & S-BLCL & S-BLCL + anti-HLA-DP & S-BLCL + anti-HLA-DR \\
\hline M8-DK4/DK5-13 & 0,13 & 6,07 & 0,23 & 4,87 \\
(DP13-reactive) & $(0,00-0,58)$ & $(1,44-17,38)$ & $(0,04-0,71)$ & $(1,69-11,09)$ \\
M7-NM1/NM2-5 & 0,16 & 41,82 & 0,83 & 29,64 \\
(DP5-reactive) & $(0,07-0,25)$ & $(28,32-65,56)$ & $(0,19-1,23)$ & $(8,64-57,89)$ \\
M4-DE/PD-17 & 0,36 & 14,48 & 0,16 & 4,69 \\
(DP17-reactive) & $(0,08-0,58)$ & $(1,47-30,04)$ & $(0,03-0,31)$ & $(0,60-8,47)$ \\
C2-DK/DK-3 & 0,00 & 17,43 & 0,20 & 15,63 \\
(DP3-reactive) & & $(14,20-19,83)$ & $(0,03-0,48)$ & $(11,72-17,47)$ \\
C11-DK/MN-3 & 0,00 & 3,51 & 0,01 & 0,53 \\
(DP3-reactive) & & $(1,89-6,44)$ & $(0,00-0,02)$ & $(0,38-0,90)$ \\
\hline
\end{tabular}

${ }^{a} \mathrm{~T}$ cell effectors were incubated with autologous R- or allogeneic S-BLCLs for 24 hours and the percentage of activated cells was determined by FACS staining for the activation marker CD137, in the presence or absence of $30 \mu \mathrm{g}$ of anti HLA-DP or -DR mAbs. Results are means based on a minimum of 3 experiments, with the ranges indicated in brackets.

\subsection{Structural homology modeling of HLA-DP identifies specific amino acids in the alpha chain as potentially relevant for $\mathrm{T}$ cell allorecognition}

To investigate which polymorphic amino acid positions of the HLA-DP alpha chain could explain the observed differences in CD4+ T cell allorecognition, all DPA1 and DPB1 alleles compared in this study were aligned (Table 4.4 and 4.5 ) and the DPA1/DPB1 combinations described below were modeled together. The resulting computer models representing multiple HLA-DP heterodimers depict the amino acid residues in the alpha chain likely to affect peptide binding or TCR interaction (Figure 4.5).

As there were significant differences in the levels of allorecognition of the heterodimers DPA1*04:01-DPB1*107:01 and DPA1*02:01-DPB1*13:01 expressed by BLCLs 15748DP107 and 15745DP13, respectively (Figure 4.3D), full length sequences of DPA1*04:01 and HLA-DPA1*02:01 were aligned and modeled together with the alignment of the full length sequences of DPB1*13:01 and DPB1*107:01. This computer model identified three amino acid differences encoded by DPA1*02:01 and *04:01 at position 31, 72 and 73 in the peptide binding groove likely to be in a position to impact peptide binding and TCR interaction (Figure 4.5A).

The recognition levels of BLCLs 15716DP05 and 30400DP135 which both carry DPA1*02:02 by our CD4+ T cell effector M7-NM1/NM2-5, were about half of the allogeneic stimulator control, positive for DPA1*02:01, *01:03, (Figure 4.3B). The full length sequences of DPA1*02:01 and HLA-DPA1*02:02 were aligned and modeled together with DPB1*05:01. This model identified a polymorphic residue at position 11 located inside the peptide binding groove as a position that could influence peptide binding (Figure 4.5B). 
Finally, the differences in CD4+ T cell allorecognition of DPB1*03:01/104:01 presented by MGAR (DPA ${ }^{*} 01: 03$ ) and VAVY (DPA1*02:01) (Figure $\left.4.3 A+C\right)$ were explored by aligning and modeling DPA1*02:01 and DPA1*01:03 in the context of DPB1*03:01 (Figure $4.5 \mathrm{C}$ ). The structure proposes the amino acid residues at position 31 inside the groove and at position 50 outside the groove as potentially able to affect peptide binding and TCR interaction.
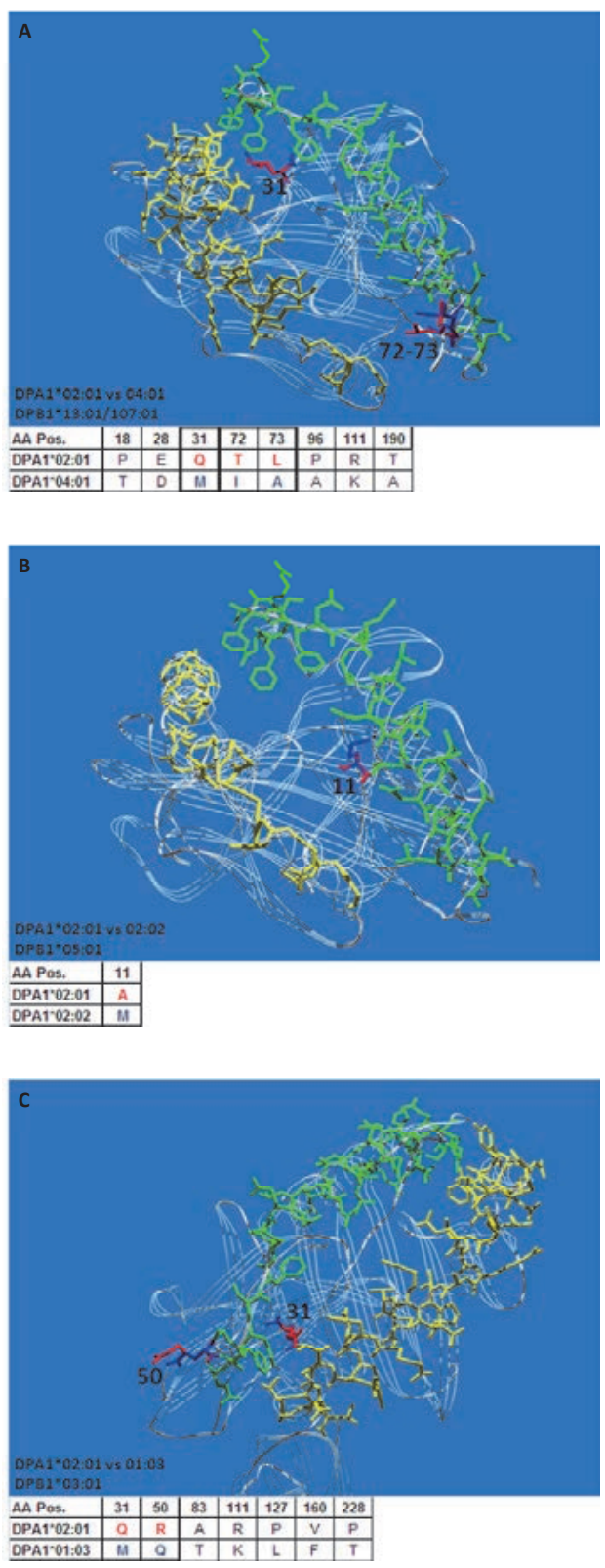
Figure 4.5 Structural homology modeling of HLA-DP identifies amino acid 11, 31, 50, 72 and 73 in the HLA-DP alpha chain as potentially relevant for T cell allorecognition. Shown is the top view of multiple HLA-DP-alpha (green) - beta (yellow) chain heterodimers as modeled on top of HLA-DP2. Polymorphic amino acid residues differing between the aligned alpha chains are indicated below each panel, and those influencing peptide binding or TCR interaction are indicated in red and blue, respectively. (A) The full length amino acid sequences of HLA-DPA $1^{*} 02: 01$ and DPA ${ }^{*}$ 04:01 were aligned and modeled together with those of HLA-DPB1*13:01 and DPB1*107:01. (B) The full length amino acid sequences of HLA-DPA ${ }^{*} 02: 01$ and DPA ${ }^{*} 02: 02$ were aligned and modeled together with that of HLA-DPB1*05:01. (C) The full length amino acid sequences of HLA-DPA1*02:01 and DPA $1 * 01: 03$ were aligned and modeled together with that of HLA-DPB1*03:01.

\section{Discussion}

Alloreactivity to HLA-DP is difficult to assign to specific amino acid polymorphism encoded by DPB1 exon $2^{24-26}$. We studied whether DPB1 polymorphism beyond exon 2 and polymorphism in the alpha chain plays a relevant role in the allorecognition of HLA-DP by established effector CD4+ T cells.

The less frequent alleles DPB1*13:01, *05:01, *03:01, *17:01 and their allele counter parts were studied for $T$ cell allorecognition as these alleles and their allele counter parts were identified in our previous study with identical exon 2 sequences but differences in other exons ${ }^{27}$. Our current study implicates that the recognition of HLA-DP by the allogeneic CD4+ T cells cannot be explained by polymorphism in the beta chain of the HLA-DP molecule only, but also seems to be affected by polymorphism in the alpha chain.

Our results indicate that the used effector $T$ cells are directed against the allogeneic HLA-DP surface molecule because T cell recognition was fully blocked by anti-DP mAb. Since minor effects from blocking HLA-DR were shown, it cannot completely be ruled out that the effector $T$ cells might have some additional DR recognition. However, since complete blocking was mediated only by anti-DP and not by anti-DR mAbs, the major component was HLA-DP specific. It cannot be ruled out that our $\mathrm{T}$ cells might recognize minor histocompatibility antigens (mHAgs) presented by allogeneic HLA-DP. In this case, these mHAgs would represent specific allopeptides required for recognition of allogeneic HLA-DP.

Several target BLCLs having identical DPA1 sequences but variations in DPB1 showed no difference in $\mathrm{CD} 4+\mathrm{T}$ cell recognition. However, all targets with deviating DPA1 background but identical DPB1 alleles resulted in a lower recognition by the effector T cells.

The targets 15745DP13 and 15748DP107 which were also recognized with significantly different efficiency by our CD4+ T cells, differ in exon 1 of DPB1. This variation in exon 1 is unlikely to cause the difference in T cell alloreactivity as this region is not expressed 
on the cell surface. It is possible that the exon 1 encoded leader peptide variant could be re-presented by allogeneic HLA-DP, as discussed above.

The influence of HLA-DPA1 on T cell alloreactivity described in our study, is in line with two other studies describing the potential interaction of polymorphic residues of the HLA-DP alpha chain with the TCR and with peptide binding ${ }^{34}$, and the importance of position 31 in particular ${ }^{33}$. This observation may be relevant for the donor selection procedure in HSCT and in the definition of immunogenicity, as a clinical study in stem cell transplantation indeed described that a DPA1 mismatch was associated with reduced survival and shorter relapse-free survival ${ }^{35}$. HLA-DPA1 polymorphism has also been associated with the risk of hepatitis $B^{49,50}$, therefore our results could also have implications for studies focusing on the molecular mechanisms of viral infections.

Hollenbach et al. ${ }^{32}$ proposed that DPA1-DPB1 heterodimer formation is dependent on amino acid epitopes in both the alpha and beta chain of the HLA-DP molecule, and suggested that $T$ cell alloreactivity could also be correlated with amino acids in the alpha chain ${ }^{32}$. Our findings underline this observation at a functional level by illustrating that polymorphism at both the alpha- and the beta chains could determine allorecognition of HLA-DP by CD4+ T cells. Although DPA1 and DPB1 are in strong $\mathrm{LD}^{31,32}$, functional heterogeneity can result from HLA-DP heterodimer formation of trans-encoded alpha-beta chain pairings. Previously, an algorithm was established based on which permissive or non-permissive DPB1 allele groups could be classified ${ }^{21-23}$, thereby identifying 3 groups. It is interesting to note that five out of six DPB1 alleles belonging to allele groups 1 and 2 are in LD with DPA ${ }^{*} 02: 01$. The DPA1*02:01 allele is less frequent in the Caucasian population compared to DPA1*01:03 (14\% vs. 81\%, respectively $)^{32}$. The significantly higher $T$ cell alloresponses to targets that share the DPA1 allele with the original stimulator cell suggest that DPA1*02:01 might be involved in forming the immunogenic epitope of non-permissive mismatches in unrelated HSCT. Functional consideration of polymorphism of the alpha chain could also be of importance for HLA-DQ an HLA-DR. Although there is no direct evidence for a functional role of DQA1, disease association studies emphasize a crucial role for DQA1 polymorphism ${ }^{51-54}$. The current study underlines the relevance of the impact of polymorphism on $\mathrm{T}$ cell allorecognition and suggests that polymorphism in the alpha chain could possibly play a more important role in HSCT and disease status than was assumed until know.

Previously, we identified DPB1 polymorphism beyond exon $2^{27}$ that encodes polymorphism in the $\beta 2$-domain, at positions aa96, aa170 and aa178. In the current study the first two positions were investigated and showed a limited impact on CD4+ T cell allorecognition. From other studies it is known that polymorphism in the $\beta 2$-domain can influence CD4 co-receptor interaction ${ }^{55,56}$ and that the region encompassing aa134 -148 of the $\beta 2$-domain in HLA-DR is the main binding site of the CD4 co-receptor ${ }^{55}$. Xiao et al. ${ }^{57}$ and Oudshoorn et al. ${ }^{58}$ suggested that the mismatch between HLA-DRB1*14:01 and HLA-DRB1*14:54, which is based on a mutation in exon 3 at position aa112, is unlikely to have a clinical effect. We suggest that CD4+ 
T cell alloreactivity can be affected by variability in the interaction between the CD4 coreceptor and the HLA class II molecule due to polymorphism in the CD4 binding site in the $\beta 2$-domain. Therefore, the lack of clinical effect with the HLA-DRB1 mismatch at position aa112, fits with the results by Cammarota et al. describing the CD4 binding site encompassing aa134-148 ${ }^{55}$. In the current study the addressed polymorphic positions were located outside the corresponding region in the DPB1 protein, namely aa134-148, and therefore they might be outside the CD4 binding site, which could explain the absence of any effect on CD4+ T cell alloreactivity. The CD4 co-receptor also binds the $\alpha 2$-domain in the region encompassing aa121-143 and CD4 co-receptor interaction is affected by mutations in this area ${ }^{59,60}$. Therefore, it might be interesting to study the functional role of the $\alpha 2$-domain of the HLA-DP molecule.

Based on our findings, we do not expect a functional role for the observed polymorphism in the $\beta 2$-domain on $\mathrm{T}$ cell allorecognition and it can be expected that these polymorphic residues have a limited clinical impact in HSCT. Our data confirm and extend our recent findings concerning limited functional relevance of the transmembrane region variability at aa205 between DPB1*03:01 and *104:01 on CD+ T cell allorecognition ${ }^{41}$. We show that this holds true independently from the DPA1 association and also for a different DPB1 variant pair at the same position 205, DPB1*05:01/135:01. Moreover, we show that exon 3-4 variability at positions 96, 170 and 194 in the DPB1*17:01/131:01 did not have a significant impact on $\mathrm{T}$ cell allorecognition unless in combination with a specific DPA1 allele. In HLA class I, it was shown that epitopes derived from the $\alpha 3$-domain and transmembrane region can impact indirect recognition by the $\mathrm{T}_{\text {cell }}{ }^{61}$, therefore a role for DPB1 exon 3 and 4 polymorphism in indirect $T$ cell recognition cannot be ruled out.

In conclusion, we observed a limited effect of polymorphism beyond the peptide binding region of the beta chain. However, we show that polymorphism of the alpha chain could affect HLA-DP immunogenicity. These new findings provide a better understanding in defining HLA-DP alloreactivity in HSCT.

\section{Acknowledgments}

The authors thank Sir Walter Bodmer (London) for kindly providing the $B 7 / 21 \mathrm{mAb}$, Prof. Luigi Naldini (Milan) for providing the LV-construct for this study, and Dr. Arend Mulder (Leiden) for kindly providing the anti-HLA-DP mAb specific for the DEAV(84-87) motif. 


\section{References}

1. Cresswell P. Assembly, transport and function of MHC class II molecules. Annu Rev Immunol 1994;12: 259-93.

2. Field J, Browning SR, Johnson LJ, Danoy P, Varney MD, Tait BD, Gandhi KS, Charlesworth JC, Heard RN; Australia and New Zealand Multiple Sclerosis Genetics Consortium, Stewart GJ, Kilpatrick TJ, Foote SJ, Bahlo M, Butzkueven H, Wiley J, Booth DR, Taylor BV, Brown MA, Rubio JP, Stankovich J. A polymorphism in the HLA-DPB1 gene is associated with susceptibility to multiple sclerosis. PLoS One 2010;5:e13454.

3. Varney MD, Valdes AM, Carlson JA, Noble JA, Tait BD, Bonella P, Lavant E, Fear AL, Louey A, Moonsamy P, Mychaleckyj JC, Erlich H; Type 1 Diabetes Genetics Consortium. HLA DPA1, DPB1 alleles and haplotypes contribute to the risk associated with type 1 diabetes: analysis of the type 1 diabetes genetics consortium families. Diabetes 2010;59:2055-62.

4. Richeldi L, Sorrentino R, Saltini C. HLA-DPB1 glutamate 69: a genetic marker of beryllium disease. Science 1993;262:242-4.

5. Dong RP, Kamikawaji N, Toida N, Fujita Y, Kimura A, Sasazuki T. Characterization of T cell epitopes restricted by HLA-DP9 in streptococcal M12 protein. J Immunol 1995;154:4536-45.

6. Castelli FA, Buhot C, Sanson A, Zarour H, Pouvelle-Moratille S, Nonn C, Gahery-Ségard H, Guillet JG, Ménez A, Georges B, Maillère B. HLA-DP4, the most frequent HLA II molecule, defines a new supertype of peptide-binding specificity. J Immunol 2002;169:6928-34.

7. Voo KS, Fu T, Heslop HE, Brenner MK, Rooney CM, Wang RF. Identification of HLA-DP3-restricted peptides from EBNA1 recognized by CD4(+) T cells. Cancer Res 2002;62:7195-9.

8. Landais E, Morice A, Long HM, Haigh TA, Charreau B, Bonneville M, Taylor GS, Houssaint E. EBV-specific CD4+ T cell clones exhibit vigorous allogeneic responses. J Immunol 2006;177:1427-33.

9. Meng Z, Wang $Y$, Zhang G, Ke Y, Yan Y, Wu L, Huang $Q$, Zeng G, Wang Y, Ying H, Jiao S. Identification of an HLA-DPB1*0501 restricted Melan-A/MART-1 epitope recognized by CD4+ T lymphocytes: prevalence for immunotherapy in Asian populations. J Immunother 2011;34:525-34.

10. Straetemans T, van Brakel M, van Steenbergen S, Broertjes M, Drexhage J, Hegmans J, Lambrecht BN, Lamers C, van Der Bruggen P, Coulie PG, Debets R. TCR gene transfer: MAGE-C2/HLA-A2 and MAGEA3/HLA-DP4 epitopes as melanoma-specific immune targets. Clin Dev Immunol 2012;2012:586314.

11. Goral S, Prak EL, Kearns J, Bloom RD, Pierce E, Doyle A, Grossman R, Naji A, Kamoun M. Preformed donor-directed anti-HLA-DP antibodies may be an impediment to successful kidney transplantation. Nephrol Dial Transplant 2008;23:390-2.

12. Thaunat O, Hanf W, Dubois V, McGregor B, Perrat G, Chauvet C, Touraine JL, Morelon E. Chronic humoral rejection mediated by anti-HLA-DP alloantibodies: Insights into the role of epitope sharing in donor-specific and non-donor specific alloantibodies generation. Transpl Immunol 2009;20:209-11.

13. Billen EV, Christiaans MH, Doxiadis, II, Voorter CE, van den Berg-Loonen EM. HLA-DP antibodies before and after renal transplantation. Tissue Antigens 2010;75:278-85.

14. Jolly EC, Key T, Rasheed H, Morgan H, Butler A, Pritchard N, Taylor CJ, Clatworthy MR. Preformed donor HLA-DP-specific antibodies mediate acute and chronic antibody-mediated rejection following renal transplantation. Am J Transplant 2012;12:2845-8.

15. Varney MD, Lester S, McCluskey J, Gao X, Tait BD. Matching for HLA DPA1 and DPB1 alleles in unrelated bone marrow transplantation. Hum Immunol 1999;60:532-8.

16. Petersdorf EW, Gooley T, Malkki M, Anasetti C, Martin P, Woolfrey A, Smith A, Mickelson E, Hansen JA. The biological significance of HLA-DP gene variation in haematopoietic cell transplantation. Brit $J$ Haematol 2001;112:988-94.

17. Shaw BE, Gooley TA, Malkki M, Madrigal JA, Begovich AB, Horowitz MM, Gratwohl A, Ringdén O, Marsh SG, Petersdorf EW. The importance of HLA-DPB1 in unrelated donor hematopoietic cell transplantation. Blood 2007; 110:4560-6.

18. Flomenberg N, Baxter-Lowe LA, Confer D, Fernandez-Vina M, Filipovich A, Horowitz M, Hurley C, Kollman C, Anasetti C, Noreen H, Begovich A, Hildebrand W, Petersdorf E, Schmeckpeper B, Setterholm M, Trachtenberg E, Williams T, Yunis E, Weisdorf D. Impact of HLA class I and class II high-resolution matching on outcomes of unrelated donor bone marrow transplantation: HLA-C mismatching is associated with a strong adverse effect on transplantation outcome. Blood 2004;104:1923-30. 
19. Lee SJ, Klein J, Haagenson M, Baxter-Lowe LA, Confer DL, Eapen M, Fernandez-Vina M, Flomenberg N, Horowitz M, Hurley CK, Noreen H, Oudshoorn M, Petersdorf E, Setterholm M, Spellman S, Weisdorf D, Williams TM, Anasetti C. High-resolution donor-recipient HLA matching contributes to the success of unrelated donor marrow transplantation. Blood 2007;110:4576-83.

20. Eapen M, Rocha V, Sanz G, Scaradavou A, Zhang MJ, Arcese W, Sirvent A, Champlin RE, Chao N, Gee AP, Isola L, Laughlin MJ, Marks DI, Nabhan S, Ruggeri A, Soiffer R, Horowitz MM, Gluckman E, Wagner JE; Center for International Blood and Marrow Transplant Research; Acute Leukemia Working Party Eurocord (the European Group for Blood Marrow Transplantation); National Cord Blood Program of the New York Blood Center. Effect of graft source on unrelated donor haemopoietic stem-cell transplantation in adults with acute leukaemia: a retrospective analysis. Lancet Oncol 2010;11:653-60.

21. Zino E, Frumento G, Marktel S, Sormani MP, Ficara F, Di Terlizzi S, Parodi AM, Sergeant R, Martinetti M, Bontadini A, Bonifazi F, Lisini D, Mazzi B, Rossini S, Servida P, Ciceri F, Bonini C, Lanino E, Bandini G, Locatelli F, Apperley J, Bacigalupo A, Ferrara GB, Bordignon C, Fleischhauer K. A T-cell epitope encoded by a subset of HLA-DPB1 alleles determines nonpermissive mismatches for hematologic stem cell transplantation. Blood 2004;103:1417-24.

22. Crocchiolo R, Zino E, Vago L, Oneto R, Bruno B, Pollichieni S, Sacchi N, Sormani MP, Marcon J, Lamparelli T, Fanin R, Garbarino L, Miotti V, Bandini G, Bosi A, Ciceri F, Bacigalupo A, Fleischhauer K; Gruppo Italiano Trapianto di Midollo Osseo, Cellule Staminale Ematopoietiche (CSE) e Terapia Cellulare; Italian Bone Marrow Donor Registry. Nonpermissive HLA-DPB1 disparity is a significant independent risk factor for mortality after unrelated hematopoietic stem cell transplantation. Blood 2009;114: 1437-44.

23. Fleischhauer K, Shaw BE, Gooley T, Malkki M, Bardy P, Bignon JD, Dubois V, Horowitz MM, Madrigal JA, Morishima Y, Oudshoorn M, Ringden O, Spellman S, Velardi A, Zino E, Petersdorf EW; International Histocompatibility Working Group in Hematopoietic Cell Transplantation. Effect of T-cell-epitope matching at HLA-DPB1 in recipients of unrelated-donor haemopoietic-cell transplantation: a retrospective study. Lancet Oncol 2012;13:366-74.

24. Cesbron A, Moreau P, Cheneau ML, Cury S, Milpied N, Muller JY, Harousseau JL, Bignon JD. Crucial role of the third and fourth hypervariable regions of HLA-DPB1 allelic sequences in primary mixedlymphocyte reaction: application in allogeneic bone marrow transplantation. Transplant Proc 1993; 25:1232-3.

25. Nicholson I, Varney M, Kanaan C, Grigg A, Szer J, Tiedemann K, Tait BD. Alloresponses to HLA-DP detected in the primary MLR: correlation with a single amino acid difference. Hum Immunol 1997;55: 163-9.

26. Díaz G, Amicosante M, Jaraquemada D, Butler RH, Guillén MV, Sánchez M, Nombela C, Arroyo J. Functional analysis of HLA-DP polymorphism: a crucial role for DPbeta residues 9, 11, 35, 55, 56, 69 and 84-87 in T cell allorecognition and peptide binding. Int Immunol 2003;15:565-76.

27. Lauterbach N, Voorter CE, Stallinga CM, Groeneweg M, Wieten L, Tilanus MG. Full-length HLA-DPB1 diversity in multiple alleles of individuals from Caucasian, Black, or Oriental origin. Tissue Antigens 2012;79:165-73.

28. Hennecke J, Wiley DC. Structure of a complex of the human a/ß T cell receptor (TCR) HA1.7, influenza hemagglutinin peptide, and major histocompatibility complex class II molecule, HLA-DR4 (DRA*0101 and DRB1*0401): insight into TCR cross-restriction and alloreactivity. J Exp Med 2002;195:571-81.

29. Kovalik JP, Singh N, Mendiratta SK, Martin WD, Ignatowicz L, Van Kaer L. The alloreactive and selfrestricted $\mathrm{CD} 4+\mathrm{T}$ cell response directed against a single $\mathrm{MHC}$ class II/peptide combination. J Immunol 2000;165:1285-93.

30. Robinson J, Halliwell JA, McWilliam H, Lopez R, Parham P, Marsh SG. The IMGT/HLA database. Nucleic Acids Res 2013;41:D1222-D7.

31. Begovich AB, Moonsamy PV, Mack SJ, Barcellos LF, Steiner LL, Grams S, Suraj-Baker V, Hollenbach J, Trachtenberg E, Louie L, Zimmerman P, Hill AV, Stoneking M, Sasazuki T, Konenkov VI, Sartakova ML, Titanji VP, Rickards O, Klitz W. Genetic variability and linkage disequilibrium within the HLA-DP region: analysis of 15 different populations. Tissue Antigens 2001;57:424-39.

32. Hollenbach JA, Madbouly A, Gragert L, Vierra-Green C, Flesch S, Spellman S, Begovich A, Noreen H, Trachtenberg E, Williams T, Yu N, Shaw B, Fleischhauer K, Fernandez-Vina M, Maiers M. A combined DPA1 DPB1 amino acid epitope is the primary unit of selection on the HLA-DP heterodimer. Immunogenetics 2012;64:559-69. 
33. Gaston JS, Goodall JC, Young JL, Young SP. Effect of polymorphism of the HLA-DPA1 chain on presentation of antigenic peptides. Hum Immunol 1997;54:40-7.

34. Reche PA, Reinherz EL. Sequence variability analysis of human class I and class II MHC molecules: functional and structural correlates of amino acid polymorphisms. J Mol Biol 2003;331:623-41.

35. Schaffer M, Aldener-Cannavá, Remberger M, Ringdén O, Olerup O. Roles of HLA-B, HLA-C and HLADPA1 incompatibilities in the outcome of unrelated stem-cell transplantation. Tissue Antigens 2003;62: 243-50.

36. Voorter CE, Lauterbach N, Tilanus MG. Inactivation of a functional HLA-A gene: a 4-kb deletion turns HLA-A*24 into a pseudogene. Hum Immunol 2010;71:1197-202.

37. Watts TH. TNF/TNFR family members in costimulation of T cell responses. Annu Rev Immunol 2005; 23:23-68.

38. Wolfl M, Kuball J, Ho WY, Nguyen H, Manley TJ, Bleakley M, Greenberg PD. Activation-induced expression of CD137 permits detection, isolation, and expansion of the full repertoire of CD8+ T cells responding to antigen without requiring knowledge of epitope specificities. Blood 2007;110:201-10.

39. Fleischhauer K, Zino E, Mazzi B, Sironi E, Servida P, Zappone E, Benazzi E, Bordignon C. Peripheral blood stem cell allograft rejection mediated by CD4(+) T lymphocytes recognizing a single mismatch at HLADP beta $1^{*} 0901$. Blood 2001;98:1122-6.

40. Amendola M, Venneri MA, Biffi A, Vigna E, Naldini L. Coordinate dual-gene transgenesis by lentiviral vectors carrying synthetic bidirectional promoters. Nat Biotechnol 2005;23:108-16.

41. Crivello P, Lauterbach N, Zito L, Sizzano F, Toffalori C, Marcon J, Curci L, Mulder A, Wieten L, Zino E, Voorter CE, Tilanus MG, Fleischhauer K. Effects of transmembrane region variability on cell surface expression and allorecognition of HLA-DP3. Hum Immunol 2013;74:970-7.

42. Sizzano F, Zito L, Crivello P, Crocchiolo R, Vago L, Zino E, Fleischhauer K. Significantly higher frequencies of alloreactive CD4+ T cells responding to nonpermissive than to permissive HLA-DPB1 T-cell epitope disparities. Blood 2010;116:1991-2.

43. Rutten CE, van Luxemburg-Heijs SA, van der Meijden ED, Griffioen M, Oudshoorn M, Willemze R, Falkenburg JH. Both permissive and nonpermissive HLA-DPB1 mismatches can induce polyclonal HLADPB1 specific immune responses in vivo and in vitro. Blood 2010;115:151-3.

44. Rutten CE, van Luxemburg-Heijs SA, Halkes CJ, van Bergen CA, Marijt EW, Oudshoorn M, Griffioen M, Falkenburg JH. Patient HLA-DP-specific CD4+ T cells from HLA-DPB1-mismatched donor lymphocyte infusion can induce graft-versus-leukemia reactivity in the presence or absence of graft-versus-host disease. Biol Blood Marrow Transplant 2013;19:40-8.

45. Wonderlich J, Shearer G, Livingstone A, Brooks A. Induction and measurement of cytotoxic T lymphocyte activity. Current protocols in immunology / edited by John E Coligan [et al]. 2006 May; Chapter 3:Unit 311.

46. Smith JG, Liu X, Kaufhold RM, Clair J, Caulfield MJ. Development and validation of a gamma interferon ELISPOT assay for quantitation of cellular immune responses to varicella-zoster virus. Clin Diagn Lab Immunol 2001;8:871-9.

47. Wang X, Greenfield WW, Coleman HN, James LE, Nakagawa M. Use of interferon-gamma enzymelinked immunospot assay to characterize novel T-cell epitopes of human papillomavirus. J Vis Exp 2012; (61). pii: 3657.

48. Thompson JD, Higgins DG, Gibson TJ. CLUSTAL W: improving the sensitivity of progressive multiple sequence alignment through sequence weighting, position-specific gap penalties and weight matrix choice. Nucleic Acids Res 1994;22:4673-80.

49. O'Brien TR, Kohaar I, Pfeiffer RM, Maeder D, Yeager M, Schadt EE, Prokunina-Olsson L. Risk alleles for chronic hepatitis $B$ are associated with decreased mRNA expression of HLA-DPA1 and HLA-DPB1 in normal human liver. Genes Immun 2011;12:428-33.

50. Nishida N, Sawai H, Matsuura K, Sugiyama M, Ahn SH, Park JY, Hige S, Kang JH, Suzuki K, Kurosaki M, Asahina $Y$, Mochida S, Watanabe M, Tanaka E, Honda M, Kaneko S, Orito E, Itoh Y, Mita E, Tamori A, Murawaki Y, Hiasa Y, Sakaida I, Korenaga M, Hino K, Ide T, Kawashima M, Mawatari Y, Sageshima M, Ogasawara Y, Koike A, Izumi N, Han KH, Tanaka Y, Tokunaga K, Mizokami M. Genome-wide association study confirming association of HLA-DP with protection against chronic hepatitis $B$ and viral clearance in Japanese and Korean. PLoS One 2012;7:e39175.

51. Yanagawa T, Mangklabruks A, DeGroot LJ. Strong association between HLA-DQA1*0501 and Graves' disease in a male Caucasian population. J Clin Endocrinol Metab 1994;79:227-9. 
52. Reed AM, Stirling JD. Association of the HLA-DQA $1^{*} 0501$ allele in multiple racial groups with juvenile dermatomyositis. Hum Immunol 1995;44:131-5.

53. Wallaschofski H, Meyer A, Tuschy U, Lohmann T. HLA-DQA1*0301-associated susceptibility for autoimmune polyglandular syndrome type II and III. Horm Metab Res 2003;35:120-4.

54. Lambert NC, Distler O, Muller-Ladner U, Tylee TS, Furst DE, Nelson JL. HLA-DQA1*0501 is associated with diffuse systemic sclerosis in Caucasian men. Arthritis Rheum 2000;43:2005-10.

55. Cammarota G, Scheirle A, Takacs B, Doran DM, Knorr R, Bannwarth W, Guardiola J, Sinigaglia F. Identification of a CD4 binding site on the beta 2 domain of HLA-DR molecules. Nature 1992;356: 799-801.

56. Fleury S, Thibodeau J, Croteau G, Labrecque N, Aronson HE, Cantin C, Long EO, Sékaly RP. HLA-DR polymorphism affects the interaction with CD4. J Exp Med 1995;182:733-41.

57. Xiao Y, Lazaro AM, Masaberg C, Haagenson M, Vierra-Green C, Spellman S, Dakshanamurthy S, Ng J, Hurley CK. Evaluating the potential impact of mismatches outside the antigen recognition site in unrelated hematopoietic stem cell transplantation: HLA-DRB1*1454 and DRB1*140101. Tissue Antigens 2009;73:595-8.

58. Oudshoorn M, Lie JL, Roelen DL, Verduyn W, Claas FHJ. Is an HLA-DRB1*1454/HLA-DRB1*1401 mismatch an acceptable mismatch in hematopoietic stem cell transplantation? Tissue Antigens 2008; 71:315-6.

59. Gaubin M, Houlgatte R, Dettin M, Scarinci C, Martin M, Guardiola J, Di Bello C, Piatier-Tonneau D. Definition of the alpha 2 region of HLA-DR molecules involved in CD4 binding. Hum Immunol 1999;60: 273-81.

60. Konig R, Shen X, Germain RN. Involvement of both major histocompatibility complex class II alpha and beta chains in CD4 function indicates a role for ordered oligomerization in T cell activation. J Exp Med 1995;182:779-87.

61. Hanvesakul R, Maillere B, Briggs D, Baker R, Larche M, Ball S. Indirect recognition of T-cell epitopes derived from the alpha 3 and transmembrane domain of HLA-A2. Am J Transplant 2007;7:1148-57. 



\section{Chapter 5}

Molecular typing of HLA-E

Nina Lauterbach, Christina E.M Voorter, Marcel G.J Tilanus Methods Mol Biol. 2012;882:143-58 


\section{Abstract}

HLA-E is a non-classical HLA class I gene that shows a limited degree of polymorphism compared to the classical HLA genes. The HLA-E molecule can bind peptides derived from the leader sequence of various HLA class I alleles and some viral homologues, including CMV. The HLA-E peptide complex can act as a ligand for the CD94/NKG2 receptors expressed on the surface of natural killer cells and T cell subsets. Differences in expression levels between the different HLA-E alleles have been reported and a role for HLA-E polymorphism in stem cell transplantation has been postulated. This chapter focuses on routine technologies for HLA-E typing: the PCR-SSP method that uses sequence-specific primers, the PCR-SSO Luminex method, using sequencespecific probes attached to beads and the SBT method, where sequencing of the alleles is performed. 


\section{Introduction}

The HLA-E gene is located between HLA-A and HLA-C on the short arm of chromosome 6. With only nine alleles encoding three different proteins, HLA-E is the least polymorphic of all MHC class I molecules. Two HLA-E molecules, encoded by HLA-E*01:01 and HLA-E*01:03, exist with about equal frequencies in the population ${ }^{1,2}$. The previously identified HLA-E*01:02 allele was removed from the IMGT/HLA database, because the sequence was found identical to HLA-E*01:01:01:01. The allele HLA-E* 01:04 has been originally reported in 1 out of 11 Japanese individuals $^{3}$, and has not been identified thereafter, even since a population of 50 Japanese individuals has been investigated. It appears very likely that this allele is the result of sequencing artefacts $^{2}$. In the remaining 8 alleles only one non-synonymous substitution is present at position 382, which results in one amino acid difference; an arginine at position 107 in $H L A-E^{*} 01: 01$ is replaced by a glycine in $H L A-E^{*} 01: 03^{4}$. All other nucleotide differences are either located in the non-coding region or are synonymous substitutions. The typing techniques described here have mainly been focused on the non-synonymous substitution, although with sequence based typing also the synonymous substitutions are identified.

It has been reported that some form of balancing selection is acting on HLA-E to maintain the two alleles ${ }^{4,5}$, implicating that there are functional differences. Indeed, a few studies show in vitro a functional difference between HLA-E*01:01 and HLA-E* $01: 03^{6-8}$. Furthermore, studies focusing on the effect of HLA-E polymorphism on stem cell transplantation outcome show a protective role for the HLA-E*01:03 genotype $^{9-12}$, albeit that the various inconclusive and contradictive results remain to be resolved and confirmed in larger cohort studies. In Behcet's disease HLA-E*01:01 seems to be associated with reduced risk ${ }^{13}$.

Different HLA-E typing techniques, like PCR-SSP, RFLP, Taqman and SBT, have been described $^{1,2,9,13,14}$. In this chapter, we describe three different routine methods to identify HLA-E polymorphism in genomic DNA. Method 1, a PCR-SSP method uses two different $5^{\prime}$ primers and a generic 3'primer that distinguish the non-synonymous difference of $H L A-E^{*} 01: 01$ and HLA-E*01:03 at amino acid position 107. Method 2, a SSO method is based on the Luminex technology, using different probes for HLA$E^{*} 01: 01, H L A-E^{*} 01: 03$ and HLA-E*01:04 attached to labelled beads. Method 3 is a direct sequencing method based upon PCR amplification and sequencing with specific primers enabling sequencing of exons 1 to 5 and the intervening introns. The noncoding differences between HLA-E*01:01:01:01, E*01:01:01:02, E*01:01:01:03 and between HLA-E*01:03:01:01, $E^{*} 01: 03: 01: 02$ are located outside this region, whereas all synonymous and non-synonymous substitutions can be detected. 


\section{Materials}

\subsection{PCR-SSP method}

\subsubsection{PCR reaction:}

1. Optional Biohazard

2. Thermocycler

3. Vortex mixer with adjustable speed

4. Centrifuge with Swing bucket rotor for 96-well microplate

5. Micropipettes and tips

6. PCR tubes (Micronics) and caps or seal.

7. Master mix (MM) for 1000 reactions (store at $-80^{\circ} \mathrm{C}$ ):

- ml 10X PCR buffer II (Perkin Elmer-buffer), (Applied Biosystems)

- $0.6 \mathrm{ml} \mathrm{MgCl} 25 \mathrm{mM}$, (Applied Biosystems)

- $20 \mu$ each dNTP 100 mM, (Amersham Pharmacia)

- Optional: $0.1 \mathrm{ml}$ Cresol red $10 \mathrm{mg} / \mathrm{ml}$, (Sigma)

- $0.5 \mathrm{ml}$ Glycerol (99,5\%), ICN

- $2.3 \mathrm{ml}$ Aqua Dest (or $2.4 \mathrm{ml}$ if no cresol red is added)

8. AmpliTaq DNA polymerase (5 Units/ $\mu$ ), (Applied Biosystems).

Store at $-20^{\circ} \mathrm{C}$

9. HLA-E amplification primers:

\begin{tabular}{lllll}
\hline Name & Direction & Sequence 5' - 3' & Location & Position \\
\hline MSSP08079 & forward & CGAGCTGGGGCCCGACA & Exon 3 & $740-756$ \\
MSSP08080 & forward & CGAGCTGGGGCCCGACG & Exon 3 & $740-756$ \\
MSSP08088 & reverse & TTCCAGGTAGGCTCTCTGG & Exon 3 & $902-920$ \\
\hline
\end{tabular}

10. Internal control primers (located in the growth hormone gene):

\begin{tabular}{lll}
\hline Name & Direction & Sequence 5'- 3 \\
\hline IC1 & forward & CAGTGCCTTCCCAACCATTCCCTTA \\
IC2 & reverse & ATCCACTCACGGATTTCTGTTGTGTTTC \\
\hline
\end{tabular}

\subsubsection{Agarose gel electrophoresis:}

1. Agarose electrophoresis grade, (Invitrogen). Store at room temperature (RT).

2. 10x TBE buffer, (Gibco) (dilute with MilliQ to obtain 0.5x TBE-dilution). Store at RT.

3. Ethidium Bromide ( $50 \mathrm{ml}, 1 \%$ in water), (Fluka Biochemika). Store at $4{ }^{\circ} \mathrm{C}$

4. $50 \mathrm{bp}$ or $100 \mathrm{bp}$ DNA ladder, (Invitrogen) (dilute $50 \mu \mathrm{l}$ DNA marker with $950 \mu \mathrm{l}$ Aqua Dest and $200 \mu \mathrm{l}$ loading buffer (dissolve in $10 \mathrm{ml}$ AD: $100 \mathrm{mg}$ Orange G, $10 \mathrm{mg}$ SDS, $200 \mu \mathrm{l} 0.5 \mathrm{M}$ EDTA, $500 \mu \mathrm{l} 1 \mathrm{M}$ Tris/ $\mathrm{HCl}$ pH 8.0, $1 \mathrm{~g}$ Ficoll 400, add $6 \mathrm{ml}$ glycerol and water to a final volume of $20 \mathrm{ml}$ ). Store at $4^{\circ} \mathrm{C}$ for max. 1 year.

5. Geltray and combs 
6. Microgram scale

7. $50^{\circ} \mathrm{C}$ water bath

8. Gel electrophoresis system, (Biorad)

9. Electrophoresis power supply

10. UV transilluminator (Geldoc system), (Biorad)

\subsection{PCR-SSO method}

\subsubsection{PCR, hybridization and luminex bead reactions}

1. HLA-E SSO Luminex kit (One Lambda, not commercially available yet)

- Denaturation buffer, store at RT

1. Neutralization buffer, store at RT

2. Hybridization buffer, store at RT

3. Wash buffer, store at RT

4. SAPE stock (100X), store at $4^{\circ} \mathrm{C}$

5. SAPE buffer, store at $4^{\circ} \mathrm{C}$

6. Primer Set D-Mix, store at $-30^{\circ} \mathrm{C}$ (mix should be pink or light purple, when necessary vortex)

7. HLA-E specific amplification primers, store at $-30^{\circ} \mathrm{C}$

8. HLA-E SSO beads (including positive and negative control beads), store at $-30^{\circ} \mathrm{C}$ (after thawing store in the dark at $4^{\circ} \mathrm{C}$, never re-freeze)

2. Optional: Biohazard

3. AmpliTaq DNA polymerase (5 Units/ $\mu \mathrm{l}$ ), (Applied Biosystems). Store at $-20^{\circ} \mathrm{C}$.

4. $1.5 \mathrm{ml}$ microfuge tubes

5. PCR tubes (micronics) and caps or seal

6. Micropipettes and tips

7. 96-well, thin walled PCR plate and holder

8. PCR Thermocycler

9. Centrifuge

- Rotor for $1.5 \mathrm{ml}$ microfuge tubes

- Swing bucket rotor for 96-well microplate

10. Vortex mixer with adjustable speed

11. Luminex fluoranalyser (Luminex Corporation) or Labscan100 (One Lambda)

12. Luminex XMap Sheath fluid 


\subsubsection{Optional: agarose gel electrophoresis, see Section 2.1 .2}

\subsection{SBT method}

\subsubsection{Amplification and sequencing reaction}

1. Expand High Fidelity PCR kit, containing 10x Expand High Fidelity buffer and Expand High Fidelity enzyme mix, (Roche)

2. dNTP $10 \mathrm{mM}$ each

3. HLA-E amplification primers:

\begin{tabular}{lllll}
\hline Name & Direction & Sequence 5'- 3' & Location & Position \\
\hline E08072 & forward & CAGCGTCGCCACGACTCCCGAC & 5'UT & 75-54 \\
E08073 & reverse & GGCTCGTGTGTGTGGATGG & Intron 5 & 2219-2237 \\
\hline
\end{tabular}

(Sequences from Paquay et al. 2009, Note 1)

4. HLA-E sequencing primers:

\begin{tabular}{lllll}
\hline Name & Direction & Sequence 5'-3' & Location & Position \\
\hline E08074 & forward & GAAGGACTCGGGGAG & Intron 1 & $131-145$ \\
E08075 & forward & AGATTCACCCCAAGGCTG & Intron 2 & $549-567$ \\
E08076 & forward & CTAAGTCCAGGCTGGTG & Intron 3 & $1465-1481$ \\
E08077 & reverse & AGCCTTGGGGTGAATC & Intron 2 & $551-564$ \\
E08078 & reverse & TCCCTGTTTCTTCTAC & Intron 3 & $1062-1077$ \\
\hline
\end{tabular}

(Sequences from Paquay et al. 2009, Note 1)

5. ExoSAP-IT, (USB corporation), store at $-20^{\circ} \mathrm{C}$

6. BigDye Terminator v1.1 Cycle Sequencing kit (Applied Biosystems) consisting of:

- 5x BigDye Terminator v1.1/3.1 sequencing buffer, store at $2-8^{\circ} \mathrm{C}$

- BigDye Terminator v1.1 cycle sequencing mix RR-2500 (BDT), store at temperatures between -15 and $-25^{\circ} \mathrm{C}$.

7. Montage $\mathrm{SEQ}_{96}$ Sequencing Reaction Cleanup kit consisting of injection solution (Millipore) and 96 well SEQ filter plates, (Montáge ${ }_{\circledast}$ life science)

8. $3700 / 3730$ BigDye $_{\circledast}$ Terminator v1.1 Sequencing standard, (Applied Biosystems), store at temperatures between -15 and $-25^{\circ} \mathrm{C}$.

9. $10 \times 3730$ buffer with EDTA, prepare fresh by adding $16 \mathrm{ml}$ of buffer to $144 \mathrm{ml}$ MilliQ water.

10. POP-7 (Performance optimized polymer), (Applied Biosystems)

11. HiDi Formamide, aliquot, freeze-thaw only once, (Applied Biosystems)

12. 96-well Optical Reaction plate with barcode (3730 plate), (Applied Biosystems)

13. 3730 Trayholder, (Applied Biosystems)

14. Plate septa 96 well, (Applied Biosystems)

15. Optional: Biohazard

16. Vortex

17. Centrifuge with Swing bucket rotor for 96-well microplate

18. Micro pipettes 
19. Pipette tips

20. $1.5 \mathrm{ml}$ microfuge tubes

21. PCR tubes (micronics)

22. Thermocycler

23. 3730 DNA analyzer, (Applied Biosystems)

\subsubsection{Requirements agarose gel electrophoresis, see Section 2.1 .2}

\section{Methods}

\subsection{PCR-SSP}

In the HLA-E PCR-SSP approach two different PCR reactions are used; one positive for HLA-E*01:01 and one positive for HLA-E*01:03. Internal amplification control primers, located in the growth hormone gene, are included to check for any inconsistencies during the PCR. Analysis is performed by agarose gel electrophoresis and by the detection of ethidium bromide stained fragments.

\subsubsection{Amplification}

1. Prepare the mastermix (MM), the DNA sample and thaw primers (see Note 2).

2. Provide a clean work environment e.g. a Biohazard and keep the reaction mixes on ice throughout the entire protocol.

3. For each sample pipette the reaction mix for HLA-E*01:01 and HLA-E*01:03 amplification as described below in two separate PCR tubes (It is most efficient to make reaction mixes before starting, see Notes 3 and 4).

1X Reaction mix HLA-E*01:01:

4,6 $\mu \mathrm{l} \quad \mathrm{MM}$

$2 \mathrm{pmol} \quad \mathrm{IC} 1$

$2 \mathrm{pmol} \quad \mathrm{IC} 2$

10 pmol forward primer: MSSP08079

10 pmol reverse primer: MSSP08088

Add aqua dest $(A D)$ to a final volume of $8 \mu \mathrm{l}$

1X Reaction mix HLA-E*01:03:

4,6 $\mathrm{ll} \quad \mathrm{MM}$

$2 \mathrm{pmol} \quad \mathrm{IC} 1$

$2 \mathrm{pmol} \quad \mathrm{IC} 2$

$10 \mathrm{pmol} \quad$ forward primer: MSSP08080

$10 \mathrm{pmol}$ reverse primer: MSSP08088

Add aqua dest (AD) to a final volume of $8 \mu \mathrm{l}$ 
4. Ad $100 \mathrm{ng}$ of DNA to each mix and centrifuge the PCR tubes (pulse centrifugation until reaching $200 \mathrm{~g}$ ).

5. Dilute Taq polymerase with $A D$ to obtain $0.33 \mathrm{U} / \mu \mathrm{l}$ and add $1 \mu \mathrm{l}$ per reaction/tube.

6. Centrifuge the PCR tubes again.

7. Cap or seal the PCR tubes and transfer them to a PCR Thermocycler.

8. Run the PCR program:

$\begin{array}{lll}2 \text { min } & 96^{\circ} \mathrm{C} & \\ 10 \text { cycles : } & 10 \mathrm{sec} & 94^{\circ} \mathrm{C} \\ & 1 \mathrm{~min} & 65^{\circ} \mathrm{C} \\ 20 \text { cycles : } & 10 \mathrm{sec} & 94^{\circ} \mathrm{C} \\ & 50 \mathrm{sec} & 61^{\circ} \mathrm{C} \\ & 30 \mathrm{sec} & 72^{\circ} \mathrm{C}\end{array}$

Hold on $4^{\circ} \mathrm{C}$

\subsubsection{Electrophoresis}

1. Transfer $200 \mathrm{ml}$ of $0.5 \%$ TBE to an Erlenmeyer and add $3 \mathrm{~g}$ agarose and mix.

2. Transfer the glass with TBE and agarose to a microwave and boil until the agarose is fully solved (see Note 5).

3. Cool the solvent by holding the glass under cold running water, swirling the glass to obtain an even temperature.

4. Put the glass covered with parafilm in a $50^{\circ} \mathrm{C}$ water bath for a minimum of 10 minutes (see Note 6).

5. Add $10 \mu \mathrm{l}$ Ethidium Bromide (final concentration $0.5 \mu \mathrm{g} / \mathrm{ml}$ ), swirl the glass and pour the gel solvent in a geltray. Discard the air bubbles and put combs in the gel.

6. Leave the gel for a minimum of 10 minutes at RT to solidify, followed by approximately 30 minutes at $4^{\circ} \mathrm{C}$.

7. Put sufficient $0.5 \times \mathrm{xBE}$ buffer in the gel electrophoresis system and add $10 \mu \mathrm{l}$ Ethidium Bromide (the gel must be completely covered by buffer).

8. Remove the combs from the geltray and put the geltray in the electrophoresis system.

9. Take the PCR tray out off the thermocycler and centrifuge the tray (pulse centrifugation until reaching $200 \mathrm{~g}$ ).

10. Load $10 \mu \mathrm{l}$ of each PCR product in each lane of the gel and $10 \mu \mathrm{l}$ of $50 \mathrm{bp}$ DNA marker in one lane.

11. Close the electrophoresis lid and run the gel for 36 minutes at $10 \mathrm{~V} / \mathrm{cm}$.

12. Following electrophoresis transfer the gel to a Geldoc system to visualize the ethidium bromide stained bands under UV-light.

\subsubsection{Analysis}

1. HLA-E*01:01 and HLA-E*01:03 specific PCR fragments have a length of $190 \mathrm{bp}$ and the internal control fragment has a length of $429 \mathrm{bp}$. When a specific fragment is 
visible for only the HLA-E*01:01 mix, and negative for the HLA-E*01:03 mix the sample is typed as HLA-E*01:01 homozygous. A sample is HLA-E*01:03 homozygous, when a specific band is visible for only the HLA-E*01:03 mix and negative for the HLA-E*01:01 mix. When for both mixes the specific fragments are present, the sample is heterozygous, HLA-E*01:01,01:03. An example is shown in Figure 5.1.

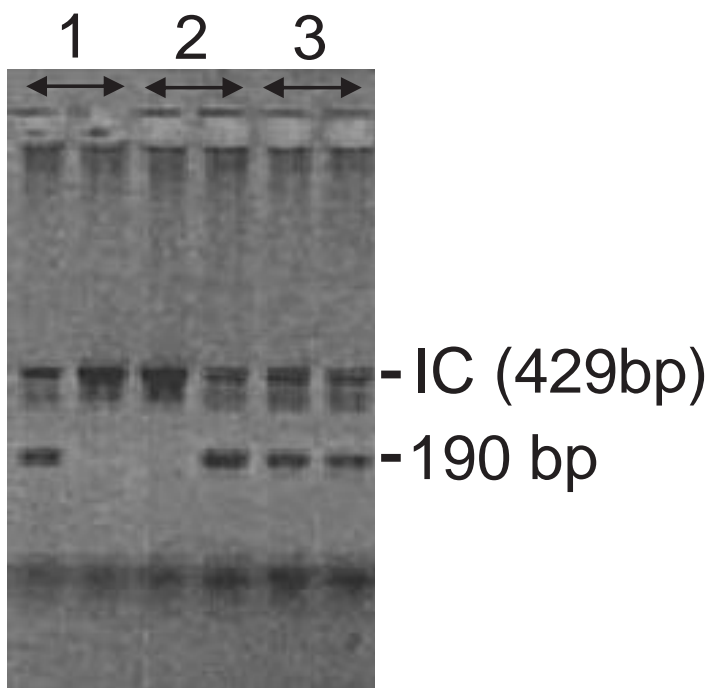

Figure 5.1 Example of PCR-SSP reactions for detection of HLA-E*01:01 and HLA-E*01:03 in three samples (See Note 6). The HLA-E specific PCR product has a fragment length of $190 \mathrm{bp}$, the internal control is 429 bp. Sample 1 is typed as HLA-E*01:01 homozygous, sample 2 as HLA-E*01:03 homozygous and sample 3 as HLA-E*01:01, ${ }^{*} 01: 03$ heterozygous.

\subsection{PCR-SSO}

For the SSO method different probes specific for HLA-E*01:01, *01:03 and *01:04 are bound to fluorescently coded beads, developed in collaboration with $\mathrm{Dr}$ J. Lee (One Lambda). HLA-E is amplified using two amplification primers each of which is labelled with biotin. After annealing of the biotinylated DNA amplicon to the beads, the DNA is labelled by addition of streptavidin coated phyco-erythrin. The fluorescence intensity is measured by luminex equipment and analysed manually to determine if the specific probes have bound the complementary DNA and thereby identify if a sample is positive for a certain allele. This method is suitable for large scale testing and easy to implement in routine luminex typing approaches. 


\subsubsection{Amplification}

1. Adjust the concentration of DNA to $20 \mathrm{ng} / \mu \mathrm{l}$ using sterile water.

2. Prepare mastermix ( $\mathrm{MM}$ ) (see Note 8) for all reactions:

Per reaction: $\quad 13.8 \mu \mathrm{l}$ D-mix*

4.0 $\mu \mathrm{l}$ HLA-E specific amplification primers

$\underline{0.2 \mu \mathrm{l}}$ Taq polymerase

$18.0 \mu \mathrm{l}$

Add the Taq polymerase immediately before use.

(*See methods part 2.2.1)

3. Pipette $2 \mu \mathrm{l}$ of DNA onto the bottom of a PCR tube.

4. Mix and centrifuge the MM and aliquot $18 \mu$ into each well containing DNA.

5. Cap or seal and transfer tubes to a PCR Thermocycler.

6. Run PCR program:

$3 \min 96^{\circ} \mathrm{C}$

5 cycles : $\quad 20 \mathrm{sec} 96^{\circ} \mathrm{C}$

$20 \sec 60^{\circ} \mathrm{C}$

$20 \mathrm{sec} 72^{\circ} \mathrm{C}$

30 cycles: $\quad 10 \mathrm{sec} 96^{\circ} \mathrm{C}$

$15 \sec 60^{\circ} \mathrm{C}$

$20 \mathrm{sec} 72^{\circ} \mathrm{C}$

$10 \min 72^{\circ} \mathrm{C}$

Hold on $4^{\circ} \mathrm{C}$

7. Amplified DNA is now ready to be tested by hybridization. Optionally 2-5 $\mu$ l of the PCR product can be used for analysis by gel electrophoresis. For method see electrophoresis in section 3.1.2 (see Note 9).

\subsubsection{Denaturation/Neutralization procedure}

1. Prepare a crushed ice bath and place a clean 96-well plate in a tray holder

2. Transfer $5 \mu$ l of PCR product into a well of the plate.

3. Add $2,5 \mu$ l Denaturation buffer per reaction, mix thoroughly, seal or cap the tray and incubate for $10 \mathrm{~min}$. at room temperature.

4. Vortex the neutralization buffer, add $5 \mu$ to each reaction, mix thoroughly (notice the colour change to clear or pale yellow) and place the plate on the ice bath.

\subsubsection{Hybridization procedure}

1. Make sure that the thermocycler has been turned on and is pre-warmed at $60^{\circ} \mathrm{C}$.

2. Prepare hybridization mixture by combining $34 \mu \mathrm{l}$ of hybridization buffer with $4 \mu \mathrm{l}$ of bead mixture per reaction, see Note 10. Protect the mixture with the fluorescently labelled beads from the light as much as possible. 
3. Keep the tray on ice to prevent early annealing. Vortex the hybridization mixture and add $38 \mu$ to each well, mix well by pipetting up and down.

4. Cover tray with tray seal and place PCR plate into the pre-warmed thermocycler.

5. Incubate for $15 \mathrm{~min}$ at $60^{\circ} \mathrm{C}$.

6. Following incubation, place tray in tray holder, remove seal and quickly add $100 \mu \mathrm{l}$ wash buffer to each well.

7. Cover tray with tray seal and centrifuge for $5 \mathrm{~min}$. at $1000-1300 \mathrm{~g}$.

8. Remove wash buffer by flicking (see Note 11).

9. Repeat the washing step twice.

10. Vortex SAPE stock and prepare $1 \mathrm{X}$ SAPE solution during third centrifugation (see Note 12):

$0.5 \mu$ S SAPE stock + $49.5 \mu$ l SAPE buffer, keep solution in the dark until use.

\subsubsection{Labelling}

1. Add $50 \mu$ of $1 X$ SAPE solution to each well, seal tray and vortex thoroughly at low speed.

2. Place PCR plate in the pre-warmed thermocycler and incubate for $5 \mathrm{~min}$ at $60^{\circ} \mathrm{C}$

3. Following incubation, place tray in holder, remove seal and quickly add $100 \mu \mathrm{l}$ wash buffer to each well.

4. Cover tray and centrifuge for $5 \mathrm{~min}$. at 1000-1300 g.

5. Remove supernatant by flicking.

6. Add $70 \mu \mathrm{l}$ wash buffer to each well, mix by pipetting and transfer $80 \mu \mathrm{l}$ to reading plate.

7. Read the plate in the Luminex apparatus.

8. If tray is not immediately read, keep it in the dark and at $4^{\circ} \mathrm{C}$ (see Note 13).

\subsubsection{Analysis}

1. The luminex output of one reaction will show the fluorescent intensity (FI) value measured for each bead in the reaction. There are 6 beads present, bead 35 is an internal negative control, no DNA must be bound to this bead. Bead 57 is a positive control, each PCR product must be bound to this bead. Bead 58 contains a probe for HLA-E*01:01, bead 59 for HLA-E*01:03 and HLA-E*01:04, bead 60 for HLA$E^{*} 01: 01$ and HLA-E*01:03 and bead 61 for HLA-E*01:04. The measured fluorescence intensity for each bead is an indication of the amount of DNA annealed to the probe. A normalized value can be calculated by [FI (bead) - FI (neg bead)]/[FI (pos bead) - FI (neg bead)] *100. If the normalized value exceeds $30 \%$, the bead is positive. Values below $30 \%$ are regarded as negative (see Note 14). Based on the positive and negative reactions, HLA-E typing can be obtained (see Table 5.1). The FI of the positive control bead must be $>1000$ and the $\mathrm{FI}$ of the negative control bead must be $<100$ (see Note 15). Bead counts need to be 100 or greater. 
Table 5.1 FI values of the various beads and the calculated normalized values. Sample 1 is typed HLA-E*01:01 homozygous, sample 2 HLA-E*01:03 homozygous and sample 3 heterozygous bearing both $\mathrm{HLA}^{*} \mathrm{E}^{*} 01: 01$ and 01:03.

\begin{tabular}{cccc}
\hline sample & 1 & 2 & 3 \\
\hline bead 35 & 14 & 12 & 3304 \\
bead 57 & 3137 & 3302 & 2414 \\
bead 58 & 2942 & 100 & 72,99 \\
normalized value bead 58 & 93,76 & 2.67 & 2150 \\
bead 59 & 41 & 2552 & 64,98 \\
normalized value bead 59 & 0,86 & 77,20 & 5314 \\
bead 60 & 5184 & 4965 & 161,00 \\
normalized value bead 60 & 165,55 & 415 & 623 \\
bead 61 & 436 & 12,25 & 18,63 \\
normalized value bead 61 & 13,51 & 12,25 & 18,63 \\
HLA-E typing result & HLA-E*01:01 & HLA-E*01:03 & HLA-E*01:01, 01:03 \\
\hline
\end{tabular}

\subsection{SBT}

For sequence based typing the HLA-E gene is amplified using primers in the $5^{\prime}$ UT region and in intron 5, enabling sequencing of exons 1 to 5 and the intervening introns. The obtained sequences are analyzed using the Lasergene software program, or equivalents, by aligning the sequence of a sample with the known HLA-E alleles. Sequence comparison will enable typing of the alleles HLA-E*01:01:01, 01:03:01, 01:03:02, 01:03:03, 01:03:04, 01:04.

\subsubsection{Amplification}

1. Provide a clean work environment e.g. a Biohazard. Keep the reaction mixes on ice throughout the entire protocol.

2. Transfer PCR tubes to a tray and put on ice, calculate the number of reactions needed and prepare one large batch of mastermix (MM) (see Note 16):

Per reaction: $5 \mu \mathrm{l} \quad$ Expand High Fidelity buffer, $10 \mathrm{X}$ conc. with $15 \mathrm{ml} \mathrm{MgCl}$

$1 \mu \mathrm{l}$ each dNTP (10 mM)

$1 \mu \mathrm{l} \quad$ forward primer E08072 $(10 \mathrm{pmol} / \mu \mathrm{l})$

$1 \mu \mathrm{l} \quad$ reverse primer E08073 $(10 \mathrm{pmol} / \mu \mathrm{l})$

$0,75 \mu \mathrm{l} \quad$ Expand high fidelity enzyme mix

Add aqua dest (AD) to a final volume of $48 \mu \mathrm{l}$

3. Pipette $48 \mu \mathrm{l} \mathrm{MM} /$ per PCR tube and add $100 \mathrm{ng}$ of DNA.

4. Centrifuge (pulse centrifugation until reaching $200 \mathrm{~g}$ ).

5. Move the PCR tubes directly to the PCR Thermocycler.

6. Run PCR program:

$2 \min 94^{\circ} \mathrm{C}$

10 cycles : $15 \mathrm{sec} 94^{\circ} \mathrm{C}$

$30 \sec 65^{\circ} \mathrm{C}$

$2 \min 72^{\circ} \mathrm{C}$ 


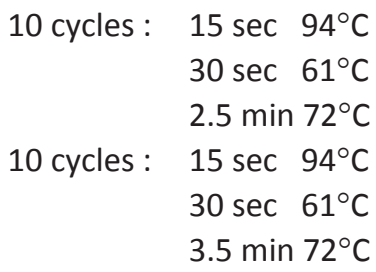

$7 \min 72^{\circ} \mathrm{C}$

Hold on $4^{\circ} \mathrm{C}$

7. After the PCR reaction 5-10 $\mu$ l of the PCR products can be checked by agarose gel electrophoresis according to the protocol in section 3.1.2, running the gel for 60 min and using a $100 \mathrm{bp}$ marker. A band with a length of $2.1 \mathrm{~kb}$ must be visible.

\subsubsection{Purification of the PCR product}

1. Pipette ExoSAP-IT in a PCR tube (all steps need to be performed on ice) followed by addition of the PCR product ( $4 \mu \mathrm{l}$ ExoSAP-IT per $10 \mu \mathrm{l}$ of PCR product), mix well and centrifuge (impuls centrifugation until reaching $200 \mathrm{~g}$ ).

2. Transfer the PCR tubes to the PCR Thermocycler.

3. Run PCR program:

$$
\begin{aligned}
& 15 \min 37^{\circ} \mathrm{C} \\
& 15 \mathrm{~min} \quad 80^{\circ} \mathrm{C} \\
& \text { Hold on } \quad 4^{\circ} \mathrm{C} \text { (See Note } 17 \text { ) }
\end{aligned}
$$

\subsubsection{Sequencing reaction}

1. In order to perform the sequencing reaction the sequencing (primer) mix has to be made (see Note 18):

Per reaction: $\quad 1.0 \mu \mathrm{l}$ BDT sequencing mix

$1.5 \mu \mathrm{l}$ BDT sequencing buffer (5X)

$0.5 \mu \mathrm{l}$ sequencing primer $(5 \mathrm{pmol})$

$\underline{6.0 \mu l}$ Aqua Dest

$9.0 \mu \mathrm{l}$

2. Pipette $9 \mu \mathrm{l}$ sequencing $\mathrm{mix}$ in a new PCR tube on ice and add $1 \mu \mathrm{l}$ purified PCR product, mix well.

3. Transfer the tubes to a PCR Thermocycler.

4. Run PCR program:

$1 \min 96^{\circ} \mathrm{C}$

25 cycles: $\quad 10 \mathrm{sec} 96^{\circ} \mathrm{C}$

$5 \mathrm{sec} \quad 50^{\circ} \mathrm{C}$

$4 \min 60^{\circ} \mathrm{C}$

Hold on $4^{\circ} \mathrm{C}$ 


\subsubsection{Purification following sequence reaction}

1. Following the sequencing reaction, purify the products by filtration using a vacuum system.

2. Mix each sequencing reaction product with $20 \mu$ of Millipore buffer (from the Montage $\mathrm{SEQ}_{96}$ Sequencing Reaction Cleanup kit) and pipette in a filter plate.

3. Put the filter plate on the vacuum system and extract for 5 minutes.

4. Add another $40 \mu \mathrm{l}$ of millipore buffer to the filter plate and extract again until all solution has been extracted (see Note 19).

5. Add $30 \mu \mathrm{l}$ of millipore buffer, put the filter plate on a vortex and shake for 10 minutes at max. 600/min.

6. Transfer $25 \mu \mathrm{l}$ of the sample to a 3730 plate, add $10 \mu \mathrm{l}$ of sequencing standard to one well on the same plate (see Note 20) and cover with a septa.

7. Put the plate in the 3730 DNA analyzer (or store for maximum 1 day at $4^{\circ} \mathrm{C}$ ) and run the sequencing program (see Note 21).

\subsubsection{Analysis}

1. The sequence output is analysed by the software Lasergene or equivalents (see Note 22). Based upon the $A \rightarrow G$ nucleotide substitution at position 382 in exon 3 (position refers to CDNA reference sequence IMGT/HLA) HLA-E*01:01 can be distinguished from HLA-E*01:03 and HLA-E*01:04. HLA-E*01:03 can be distinguished from HLA-E*01:04 by the difference at position 532, *01:03 has an A at this position, whereas *01:04 has a G. HLA-E*01:03:01, *01:03:02, *01:03:03 and $* 01: 03: 04$ can be identified based upon the nucleotide substitutions at positions 294,513 and 696 .

\section{Notes}

1. The method described by Paquay et al. ${ }^{14}$ is the sole proprietary knowledge of Genome Diagnostics BV Utrecht, the Netherlands.

\subsection{PCR-SSP method}

2. It is most efficient to prepare the master mixes in large amounts for multiple samples and aliquot.

3. Vortex the primers before adding to the mixes.

4. It is most efficient to prepare reaction mixes in larger amounts for multiple samples. Prepared reaction mixes can be stored at $-80^{\circ} \mathrm{C}$.

5. It is important to boil long enough until all agarose particles are fully dissolved in the TBE buffer and when cooling down to swirl the glass to prevent unequal solidification of the gel. 
6. The temperature of the gel mixture must not exceed $60^{\circ} \mathrm{C}$ when ethidium bromide is added, because this high temperature will destroy the ethidium bromide.

7. Very weak or invisible DNA bands (including internal control) can be caused by insufficient mixing of Taq polymerase before adding it to the primer/DNA mixes.

\subsection{PCR-SSO method}

8. Vortex D-mix and amplification primers before adding to the mix.

9. PCR products can be stored at $-80^{\circ} \mathrm{C}$ to $-20^{\circ} \mathrm{C}$.

10. Vortex beads well before adding. Once beads are thawed, store beads at $2{ }^{\circ} \mathrm{C}$ to $8^{\circ} \mathrm{C}$ and use within three months. Do not refreeze bead mixture after thawing.

11. Try to remove (flick) as much wash buffer as possible by inverting the tray and pouring into the waste in one movement. To perform this accurately training is needed. If you do not succeed in removing all wash buffer at once, you have to repeat the flicking, however you will have a higher risk of loosing beads. Leaving too much wash buffer can affect your results (see Note 15).

12. Remove the SAPE bottle from storage only when needed, and return immediately to $2^{\circ} \mathrm{C}$ to $8^{\circ} \mathrm{C}$.

13. Prolonged storage of samples (more than 4 hours) may result in loss of signal.

14. Since HLA-E*01:04 has never been detected after its initial identification, it has not been possible to check the specificity of the HLA-E*01:04 bead.

15. In case MFI values of the control beads are out of range (too low positive or too high negative control values), we consider it necessary to repeat the procedure. When the MFI value of the positive beads is too low this could be caused by inadequate PCR amplification, that can be checked by agarose gel electrophoresis. If a correct strong PCR band is observed, the too low positive control value might be caused by insufficient flicking, resulting in a lower concentration of SAPE. A too high negative control value might be due to some contamination. Repeating the reactions with new reagents might be necessary.

\subsection{SBT method}

16. Vortex the primers before adding to the mixes.

17. The purified PCR product can be stored for a maximum of one week at $4^{\circ} \mathrm{C}$.

18. The amplification primers can also be used as sequencing primers in addition to the described sequencing primers.

19. It is important that all fluid has been extracted, otherwise it can result in a higher background because the remaining labelled dNTP's could interfere with the sequence analysis.

20. The sequencing standard can be run to check for any inconsistencies during the capillary electrophoresis and analysis procedure.

21. The sequencing reaction products can be analysed by any automated DNA sequencer that is able to detect the Big Dye Terminator labelled nucleotides. 
22. After DNA sequence analysis the sequences are stored in .AB1 files. DNASTAR software Lasergene contains EDITSEQ, ALIGN and SEQMAN modules. Individual sequences are selected, these are the sample $A B 1$ files, and HLA-E sequences obtained from the IMGT/HLA database/ EBI (www.ebi.ac.uk/imgt/hla) are used as reference. The uploaded reference and sample sequence files are assembled by SEQMAN. From the resulting contig the nucleotide peaks can be viewed, checked and if necessary adjusted. Extended sequences obtained as displayed in the contig can be used as reference sequence additionally. Lasergene software is a product from DNASTAR, Madison, USA.

\section{Acknowledgement}

The authors thank Jarhow Lee (One Lambda, Los Angeles, USA) for the development of the HLA-E SSO kit and reagents and Els Bielen and Timo Olieslagers for their practical assistance. 


\section{References}

1. Antoun A, Jobson S, Cook M, Moss P, Briggs D. Ethnic variability in human leukocyte antigen-E haplotypes. Tissue Antigens 2009;73:39-45.

2. Grimsley C, Kawasaki A, Gassner C, Sageshima N, Nose Y, Hatake K, Geraghty DE, Ishitani A. Definitive high resolution typing of HLA-E allelic polymorphisms: Identifying potential errors in existing allele data. Tissue Antigens 2002;60:206-12.

3. Ohya K, Kondo K, Mizuno S. Polymorphism in the human class I MHC locus HLA-E in Japanese. Immunogenetics 1990;32:205-9.

4. Grimsley C, Ober C. Population genetic studies of HLA-E: evidence for selection. Hum Immunol 1997; 52:33-40.

5. Geraghty DE, Stockschleader M, Ishitani A, Hansen JA. Polymorphism at the HLA-E locus predates most HLA-A and -B polymorphism. Hum Immunol 1992;33:174-84.

6. Ulbrecht M, Couturier A, Martinozzi S, Pla M, Srivastava R, Peterson PA, Weiss EH. Cell surface expression of HLA-E: interaction with human beta2-microglobulin and allelic differences. Eur J Immunol 1999;29:537-47.

7. Strong RK, Holmes MA, Li P, Braun L, Lee N, Geraghty DE. HLA-E allelic variants. Correlating differential expression, peptide affinities, crystal structures, and thermal stabilities. J Biol Chem 2003;278:5082-90.

8. Maier S, Grzeschik M, Weiss EH, Ulbrecht M. Implications of HLA-E allele expression and different HLA-E ligand diversity for the regulation of NK cells. Hum Immunol 2000;61:1059-65.

9. Tamouza R, Rocha V, Busson M, Fortier C, El Sherbini SM, Esperou H, Filion A, Socié G, Dulphy N, Krishnamoorthy R, Toubert A, Gluckman E, Charron D. Association of HLA-E polymorphism with severe bacterial infection and early transplant-related mortality in matched unrelated bone marrow transplantation. Transplantation 2005;80:140-4.

10. Tamouza R, Busson M, Rocha V, Fortier C, Haddad Y, Brun M, Boukouaci W, Bleux $H$, Socié G, Krishnamoorthy R, Toubert A, Gluckman E, Charron D. Homozygous status for HLA-E*0103 confers protection from acute graft-versus-host disease and transplant-related mortality in HLA-matched sibling hematopoietic stem cell transplantation. Transplantation 2006;82:1436-40.

11. Danzer M, Polin H, Pröll J, Haunschmid R, Hofer K, Stabentheiner S, Hackl C, Kasparu H, König J, Hauser $H$, Binder M, Weiss R, Gabriel C, Krieger O. Clinical significance of HLA-E*0103 homozygosity on survival after allogeneic hematopoietic stem-cell transplantation. Transplantation 2009;88:528-32.

12. Ludajic K, Rosenmayr A, Faé I, Fischer GF, Balavarca Y, Bickeböller H, Kalhs P, Greinix HT. Association of HLA-E polymorphism with the outcome of hematopoietic stem-cell transplantation with unrelated donors. Transplantation 2009;88:1227-8.

13. Park KS, Park JS, Nam JH, Bang D, Sohn S, Lee ES. HLA-E*0101 and HLA-G*010101 reduce the risk of Behcet's disease. Tissue Antigens 2007;69:139-44.

14. Paquay MM, Schellekens J, Tilanus MG. A high-throughput Taqman(R) approach for the discrimination of HLA-E alleles. Tissue Antigens 2009;74:514-9. 



\section{Chapter 6}

The induction of HLA-E translation upon extracellular peptides in human PBMCs is dependent on peptide sequence and HLA-E genotype

Nina Lauterbach, Lotte Wieten, Herman E. Popeijus, Joris Vanderlocht, Petronella M.H. van Zon, Christina E.M. Voorter, Marcel G.J. Tilanus 


\section{Abstract}

HLA-E is a low-polymorphic non classical HLA class I molecule which plays a crucial role in immune surveillance by presentation of peptides to T and NK cells. HLA-E polymorphism is related with HLA-E surface expression in cell lines and is associated with patient outcome after stem cell transplantation. We aim to investigate the regulation of HLA-E expression level in peripheral blood mononuclear cells (PBMCs) of healthy subjects homozygous for HLA-E*01:01 or HLA-E*01:03, by using a panel of HLA-E binding peptides derived from CMV, Hsp60 and HLA class I. Basal and peptide induced HLA-E surface expression levels were higher in PBMC from HLA$E^{*}$ 01:03 homozygous subjects when compared to PBMC from HLA-E*01:01 homozygous subjects. After re-stimulation with peptide, HLA-E expression level of HLA-E*01:03 was even more induced as compared to the initial peptide stimulation, while in HLA-E*01:01 induction remained at the same level. HLA-E transcription was comparable between the two genotypes and remained constant after peptide stimulation. HLA-E surface expression seemed not only to be dependent on the HLA-E genotype, as evidenced by the profound difference in HLA-E upregulation with the Hsp60 and B7 peptide. Interestingly, our results showed that peptide-induced HLA-E expression is regulated at translational level as extracellular peptide stimulation triggered the translation of new HLA-E molecules, and this synthesis was inhibited by $\mathrm{CHX}$. This study provides new insides in the mechanism by which HLA-E expression level is regulated and underlines a new role for extracellular peptides in inducing HLA-E translation. 


\section{Introduction}

HLA-E is a non-classical HLA class I molecule which plays a crucial role in immune surveillance. HLA-E can be recognized by $T$ cells in a $T$ cell receptor-dependent manner $^{1-3}$ and serves as a ligand for natural killer (NK) cell receptors ${ }^{4-6}$. NK cells interact with the HLA-E-peptide complex via C-type lectin-like NKG2 receptor family members ${ }^{7}$, which can provide either an inhibitory (NKG2A/B) or activating (NKG2C/E/H) signal.

HLA-E is expressed in most tissues, though at relatively low levels as compared to classical HLA class I molecules. For stable HLA-E surface expression, binding of a restricted set of nonamer peptides is required and the peptides are derived from the signal sequences of the classical HLA class I molecules and HLA-G ${ }^{8,9}$. Because HLA-E binding peptides require TAP to enter the ER, HLA-E serves as a remote sensor of TAP function and of classical HLA class I expression ${ }^{8}$. However, HLA-E can also bind peptides from viral-, bacterial- or stress-protein origin suggesting that it can be used by NK cells and $T$ cells to broadly monitor cellular-stress, -integrity and-infection ${ }^{10-14}$.

HLA-E is the least polymorphic of all HLA class I alleles with only thirteen alleles encoding five different proteins described in the human population. HLA-E*01:01 and HLA-E*01:03 have been detected in the population at high frequencies and have been proposed to be under some form of stabilizing selection ${ }^{15,16}$, which suggests that there may be functional differences between the two alleles. These two alleles differ by a single amino acid on the alpha2 domain of the HLA-E heavy chain, HLA-E*01:01 encodes an Arg at position 107 were HLA-E*01:03 has a Gly.

Importantly, there are indications in literature that the HLA-E genotype has clinical implications. In the hematopoietic stem cell transplantation (HSCT) setting, the HLA$E^{*}$ 01:03 genotype has been associated with lower occurrence of graft-versus-host disease, relapse and transplantation related mortality, and with a better survival as compared to the HLA-E*01:01 genotype ${ }^{17-22}$. In two independent patient cohorts of unrelated HSCT we recently found that HLA-E*01:03, in either the patient or the donor, is associated with a higher risk of infection (manuscript in preparation). The mechanisms by which HLA-E genotype determines this in vivo remain unclear, but studies using cell lines in which HLA-E variants are transfected show that the level of HLA-E on the cell surface is determined by the sequence of the peptide bound to HLA-E $\mathrm{E}^{7-9,12,23-26}$ and by allelic polymorphism ${ }^{9,24,27}$. HLA-E seems to be higher expressed in HLA-E*01:03 positive cell lines when compared to HLA-E*01:01 positive cell lines ${ }^{9,24,27}$ which could be attributed to the finding that HLA-E*01:03 encodes for a protein variant with a relatively higher peptide binding affinity than $H L A-E^{*} 01: 01^{24}$.

To fully understand the regulatory mechanisms of HLA-E surface expression level further investigation is required. As previous studies show that the in-vitro situation can vary from the in-vivo situation ${ }^{28-30}$, we used peripheral blood mononuclear cells (PBMCs) derived from healthy subjects homozygous for HLA-E*01:01 or HLA-E*01:03 instead of cell lines. We studied HLA-E expression and regulation in these PBMCs at basal levels and upon incubation with a panel of peptides including all known leader 
peptides of HLA class I, some CMV peptides and an Hsp60 peptide.

\section{Materials and methods}

\subsection{Cells and donor selection}

PBMCs were isolated from heparinized blood from healthy volunteer donors by lymphoprep density gradient centrifugation. Cells were cultured in RPMI-1640 with $10 \% \mathrm{FCS}$ and $1 \%$ pen/strep (Invitrogen) in 96 well-plates at $5 \% \mathrm{CO}_{2}$ and $37^{\circ} \mathrm{C}$. Subjects homozygous for HLA-E*01:01 or HLA-E*01:03 were selected after genotyping for $H L A-E^{31}$.

\subsection{Peptide incubation for HLA-E expression analysis}

PBMCs $\left(2 * 10^{5}\right.$ in $\left.200 \mu \mathrm{l}\right)$ were incubated with the peptides indicated in Table 6.1 (Biosythesis Inc.) at $500 \mu \mathrm{M}$ (unless stated otherwise). These peptides represent sequences of HLA class I leader peptides, CMV derived peptides (which are identical to HLA class leader peptides but are referred throughout the article as CMV peptides) and Hsp60 peptide. As negative controls, cells were incubated with medium, DMSO (peptide solvent) or non-HLA-E binding control peptide. After indicated time, cells were further analyzed for HLA-E expression by flow cytometry, western blot or RT-PCR as described below. For some experiments, $10 \mu \mathrm{g} / \mathrm{ml}$ Cycloheximide (CHX) (Sigma-Aldrich) was added before peptide incubation.

\subsection{Flow cytometry}

Cells were stained for surface HLA-E (3D12 directly labeled with PE, eBioscience) and HLA-ABC (W6/32 directly labeled with FITC, BD Bioscences) ${ }^{32}$. Staining for intracellular HLA-E with Cytofix/Cytoperm (BD Biosciences) was performed according to manufacturer's protocol. Data were acquired on a FACSCalibur (BD Biosciences) and analyzed with BD FACSDiva software 6.1.2.

\subsection{Quantitative RT-PCR}

RNA was isolated from $2 * 10^{5}$ PBMC with RNeasy minikit (Qiagen). cDNA synthesis was performed with Superscript II first-strand synthesis system (Invitrogen). The qRT-PCR, was carried out in a $25 \mu \mathrm{l}$ reaction volume, containing $12.5 \mu \mathrm{l}$ TaqMan Universal PCR Master Mix (2X) (10 $\mu \mathrm{M}$ Tris- $\mathrm{HCl}$ at $\mathrm{pH} 8.3,50 \mu \mathrm{M} \mathrm{KCl}, 5 \mu \mathrm{M} \mathrm{MgCl} 2,0.5 \mu \mathrm{M}$ dNTPs) (Roche), $200 \mathrm{nM}$ of probe, $300 \mathrm{nM}$ of forward primer, $300 \mathrm{nM}$ of reverse primer (Applied Biosystems) and $1 \mu \mathrm{l}$ of the template cDNA. The following program was used; $50^{\circ} \mathrm{C}$ for $2 \mathrm{~min}, 95^{\circ} \mathrm{C}$ for $10 \mathrm{~min}$ and 40 cycles of $95^{\circ} \mathrm{C}$ for $15 \mathrm{sec}$ and $60^{\circ} \mathrm{C}$ for $1 \mathrm{~min}$ using the 7900 HT Fast Real-Time PCR System (Applied Biosystems). HLA-E RNA 
expression level was analyzed by qRT-PCR on 7900 HT Fast Real-Time PCR System (Applied Biosystems). Relative changes of gene expression were calculated by the Pfaffl method $^{33}$. GAPDH was used as reference gene for normalization. GAPDH primer and probe sequences were retrieved from Sui et al. ${ }^{34}$ and HLA-E primers were derived from Paquay et al. ${ }^{3539}$. The HLA-E TaqMan probe, selected between the primers, was fluorescent-labeled at the $5^{\prime}$ end with 6-carboxyfluorescein (FAM) as the reporter dye and at the $3^{\prime}$ end with Black Hole Quencher (BHQ) as the quencher; 5'-6FAMATGAACAGTTCGCCTA-BHQ1-3'. cDNA from a human cell line endogenously expressing HLA-E was used as an interplate calibrator.

\subsection{Western blot}

In short, $30 \mu \mathrm{g}$ of protein sample was electrophoresed by $10 \%$ SDS-PAGE. Proteins were transferred onto nitrocellulose membranes at $100 \mathrm{~mA}$ overnight at $4^{\circ} \mathrm{C}$. The blots were blocked for 1 hour with 5\% non-fat dry milk in PBS/ 0.1\% Tween20 at room temperature. The membranes were probed with mouse anti-HLA-E, MEM-E/02, (Abcam) and rabbit anti- $\beta$-actin antibodies (Cell Signaling Technology Inc.). Visualization was performed using chemiluminescence reagent (Pierce Biotechnology).

\subsection{Statistics}

Data was analyzed by GraphPad Prism (GraphPad Software, La Jolla, CA, USA) by Student's unpaired two-tailed t-test or two-way ANOVA with bonferroni post-test. A $p$-value of below 0.05 was considered significant.

\section{Results}

\subsection{PBMCs from HLA-E*01:03 donors express higher levels of cell surface HLA-E than PBMCs from HLA-E* 01:01 donors}

To investigate which factors determine HLA-E surface expression in PBMCs, we studied whether allelic variation influenced the basal expression level of HLA-E. PBMCs were isolated from twenty-six healthy individuals homozygous for either HLA-E*01:01 or HLA-E*01:03, and HLA-E protein surface and RNA expression was analyzed, directly upon isolation, by flow cytometry and qRT-PCR respectively. In all subjects, a low level of HLA-E was expressed on the surface of lymphocytes. The mean fold expression (MFI of HLA-E divided by the MFI of the isotype control of the same individual) was significantly higher in individuals homozygous for HLA-E*01:03 as compared to HLA$E^{*} 01: 01$ homozygous persons (Figure 6.1A). This difference was not confined to the lymphocyte subset, but was also demonstrable in the monocytes gate (not shown). We did not observe a difference in the relative RNA content (Figure 6.1B). Total HLA class I surface expression was comparable for both genotypes (Figure 6.1C). 

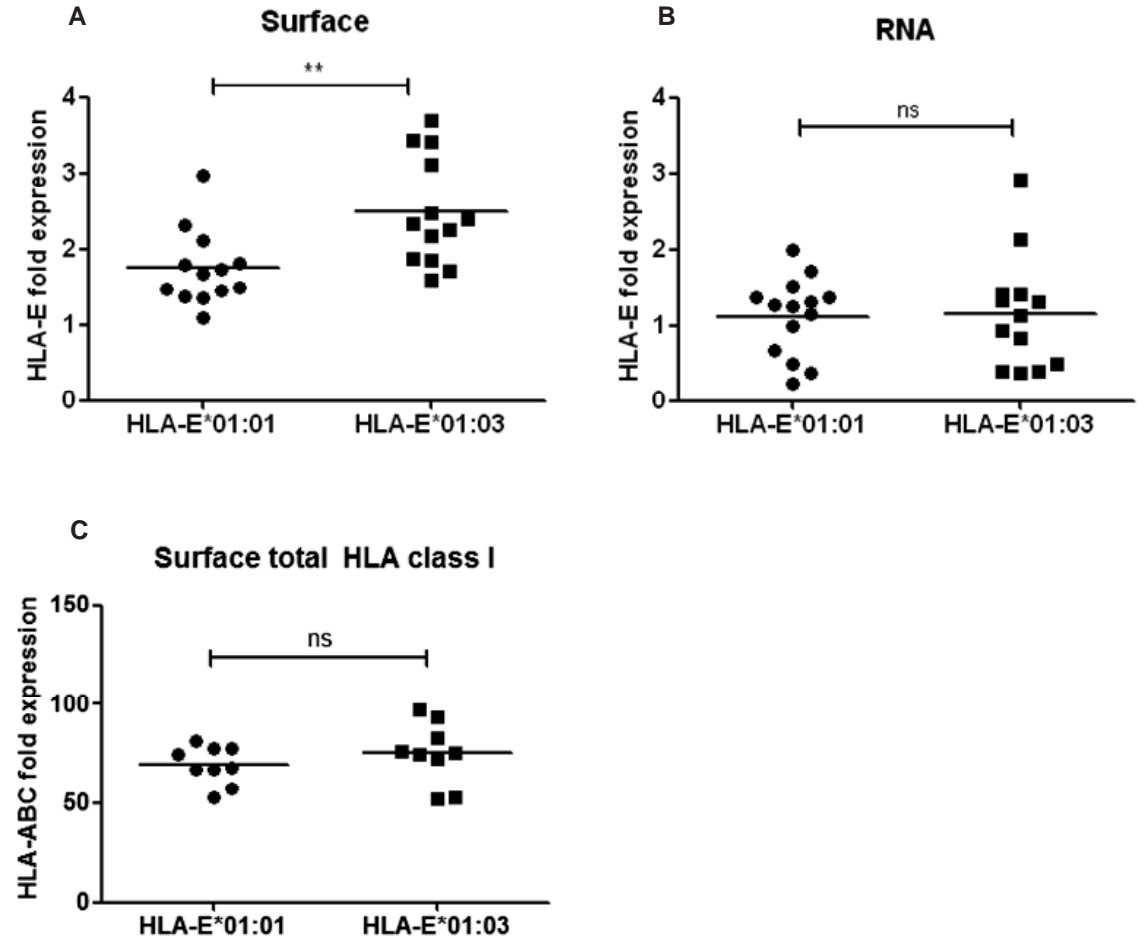

Figure 6.1 Basal HLA-E surface, but not RNA expression levels and total HLA class I expression levels in PBMC, are dependent on HLA-E genotype. Basal HLA-E surface fold expression (A), relative HLA-E mRNA expression level (B) and total HLA class I expression level (C) was analyzed directly upon isolation in PBMC derived from healthy HLA-E*01:01 homozygous subjects and HLA-E*01:03 homozygous subjects. A) HLA-E surface expression was analyzed with flow cytometry and depicted per subject as fold expression (MFI HLA-E/MFI isotype control) after gating on lymphocytes based on FSC/SCC. B) HLA-E fold mRNA expression levels were analyzed by qRT-PCR. CT values of HLA-E were normalized to GAPDH. C) HLA class I surface expression was analyzed with flow cytometry and depicted per subject as fold expression (MFI HLA class I /MFI isotype control) after gating on lymphocytes based on FSC/SCC. Every dot represents a subject. The horizontal bars correspond to the means per group of subjects. ${ }^{*} p<0.01$. ns $=$ not signifiant

\subsection{HLA-E genotype and peptide binding to HLA-E determine HLA-E cell surface expression in PBMCs}

To study the influence of HLA-E binding peptides on HLA-E surface and RNA expression, PBMCs, from six individuals (three per homozygous genotype), were incubated with DMSO, the control (Cntrl)-, B15-, CMV(V)- or Hsp60 peptide at $500 \mu \mathrm{M}$. This concentration induced a robust up-regulation of HLA-E in an experiment where we tested multiple peptide concentrations (data not shown). One (for RNA expression only), 2, 4, 6, 13, 20, 27 and 44 hours later, HLA-E surface protein and RNA expression 
was examined. In all subjects, HLA-E surface expression remained constant over time upon incubation with the control peptide or DMSO (Figure 6.2A+B).

A

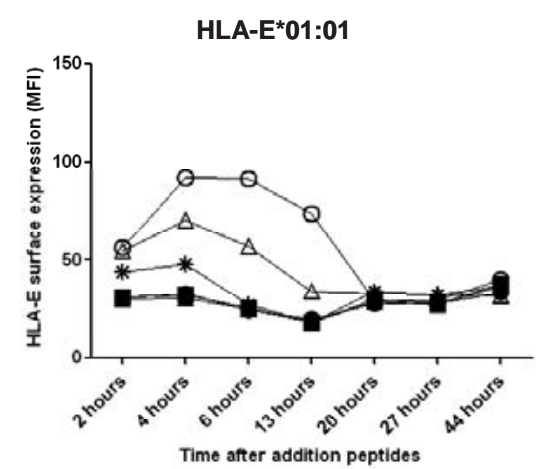

C

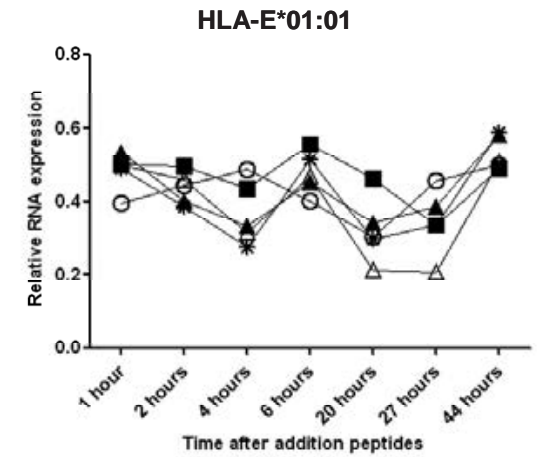

B

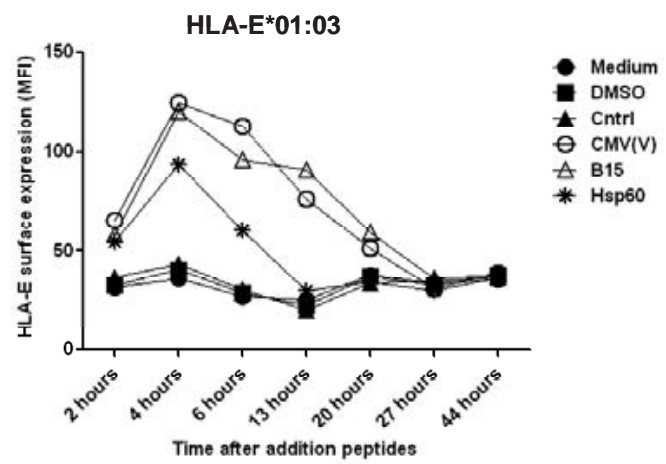

D

HLA-E*01:03

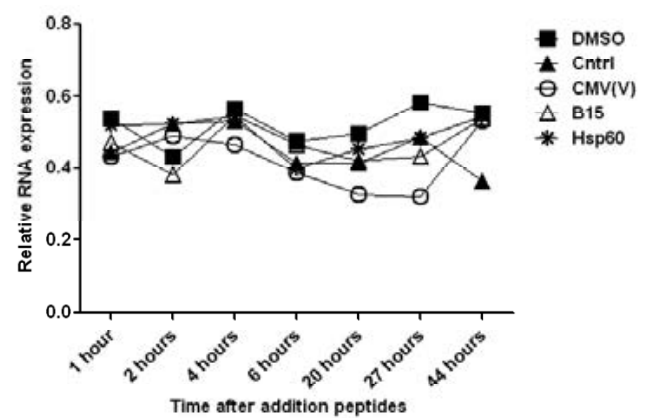

Figure 6.2 HLA-E surface expression, but not RNA expression, is upregulated between 2 and 13 hours after peptide incubation in PBMCs from healthy donors. PBMCs derived from at least three healthy HLA-E*01:01 and three HLA-E*01:03 homozygous subjects were incubated with various HLA-E binding peptides at $500 \mu \mathrm{M}$ or control conditions (medium, DMSO and control peptide) and analyzed for HLA-E surface $(\mathbf{A}+\mathbf{B})$ and HLA-E relative mRNA expression level $(\mathbf{C}+\mathbf{D})$ at indicated time points after peptide addition. HLA-E surface expression was analyzed with flow cytometry. HLA-E mRNA relative expression levels were analyzed by qRT-PCR. CT values of HLA-E were normalized to GAPDH. Lines represent means of at least 3 different subjects.

HLA-E levels were enhanced between 2 and 13 hours after addition of CMV(V) and B15 peptides, and returned to basal level after 13 hours. For Hsp60 peptide, the kinetics were different and HLA-E was elevated between 2 and 4 hours and decreased very rapidly thereafter. The level of Hsp60-induced HLA-E was lower than with $\mathrm{CMV}(\mathrm{V})$ or B15 peptide. HLA-E levels were higher in HLA-E*01:03 individuals, however, the kinetics were comparable between both genotypes. In contrast to protein expression, HLA-E 
RNA expression remained constant over time and we could not observe an induction with any of the peptides (Figure 6.2C+D).

To obtain a comprehensive overview of the influence of the peptide sequence on HLA-E expression, PBMCs from twenty different individuals, homozygous for either HLA$E^{*} 01: 01$ or HLA-E*01:03, were incubated for 14 hours with a more extensive panel of peptides including peptides derived from all known leader sequences of the different HLA class I alleles, three peptides belonging to various CMV strains (which are identical to the sequences of various HLA class leader peptides) and the Hsp60 peptide (Table 6.1). The mean fold HLA-E expression was calculated (MFI of HLA-E divided by the MFI of the medium control of the same individual). For both genotypes, HLA-E surface expression was enhanced upon incubation with all HLA-E binding peptides except for the Hsp60 and the control peptide. Notably, the level of HLA-E induction was dependent on the peptide; e.g. relatively high induction by CMV and B7 peptides and low induction by Hsp60 and B13 peptides. For the Hsp60 and B7 peptide, the induction in HLA-E was not significantly different between the two genotypes. For the other peptides, induced HLA-E levels were significantly higher on the surface of HLA-E*01:03 homozygous PBMCs as compared to HLA-E*01:01 homozygous PBMCs (Figure 6.3).

Table 6.1 Peptides used for HLA-E peptide incubation assays.

\begin{tabular}{|c|c|c|}
\hline Name peptide & sequence & Derived from \\
\hline Control peptide & RGPGRAFVTI & (Michaëlsson J. et al. 2002) \\
\hline $\operatorname{CMV}(\mathrm{L})$ & VMAPRTLLL & $\begin{array}{l}\text { HLA-A*01, }-A^{*} 03,-A^{*} 11,-A^{*} 29,-A^{*} 30, A^{*} 31,-A^{*} 32,-A^{*} 33,-A^{*} 36 \text {, } \\
\text { and } A^{*} 74, \text { HLA-Cw02 and } C C^{*} 15\end{array}$ \\
\hline $\mathrm{CMV}(\mathrm{V})$ & VMAPRTLVL & $\begin{array}{l}\text { HLA }-A^{*} 02,-A^{*} 23,-A^{*} 24,-A^{*} 25,-A^{*} 26,-A^{*} 34: 02,-A^{*} 34: 06 \\
-A^{*} 43,-A^{*} 66, \text { and }-A^{*} 69\end{array}$ \\
\hline $\mathrm{CMV}(\mathrm{I})$ & VMAPRTLIL & 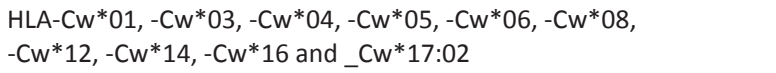 \\
\hline Hsp60(sp) & QMRPVSRVL & Hsp60 \\
\hline A34 & IMAPRTLVL & HLA-A*34:01 \\
\hline A80 & VMPPRTLLL & HLA-A*80 \\
\hline B7 & VMAPRTVLL & $\begin{array}{l}\text { HLA-B*07, }-B^{*} 08,-B * 14,-B * 38,-B * 39,-B * 39,-B * 42,-B 48-B * 67 \\
-B^{*} 73 \text { and }-B^{*} 81\end{array}$ \\
\hline B13 & VTAPRTLLL & $\begin{array}{l}\text { HLA-B*13, }-B^{*} 18,-B * 27,-B * 37,-B * 40,-B * 44,-B * 47,-B * 54 \\
B * 55-B * 56,-B * 59,-B * 82 \text { and } B * 83\end{array}$ \\
\hline B15 & VTAPRTVLL & $\begin{array}{l}\text { HLA-B*15, -B35, -B*40, -B*41, -B*44:18, -B*45, -B*46-B*49, } \\
-B^{*} 50,-B^{*} 51,-B^{*} 52,-B * 53,-B * 57,-B * 58 \text { and }-B^{*} 78\end{array}$ \\
\hline $\mathrm{C} 8$ & VMAPRTLTL & $\mathrm{HLA}-\mathrm{CW}^{*} 08: 09$ \\
\hline C7 & VMAPRALLL & HLA-Cw*06:17, $-\mathrm{Cw}^{*} 07$ and $-\mathrm{Cw}^{*} 18$ \\
\hline C17 & VMAPQALLL & HLA-Cw*17:01, Cw*17:03 and $-\mathrm{Cw}^{*} 17: 05$ \\
\hline G & VMAPRTLFL & HLA-G*01 \\
\hline
\end{tabular}

The panel of peptides include one control peptide that is not able to bind to HLA-E, three peptides belonging to various CMV strains (which are identical to leader sequences of various HLA class I alleles), the Hsp60 peptide and peptides derived from all known leader sequences of the different HLA class I alleles. 


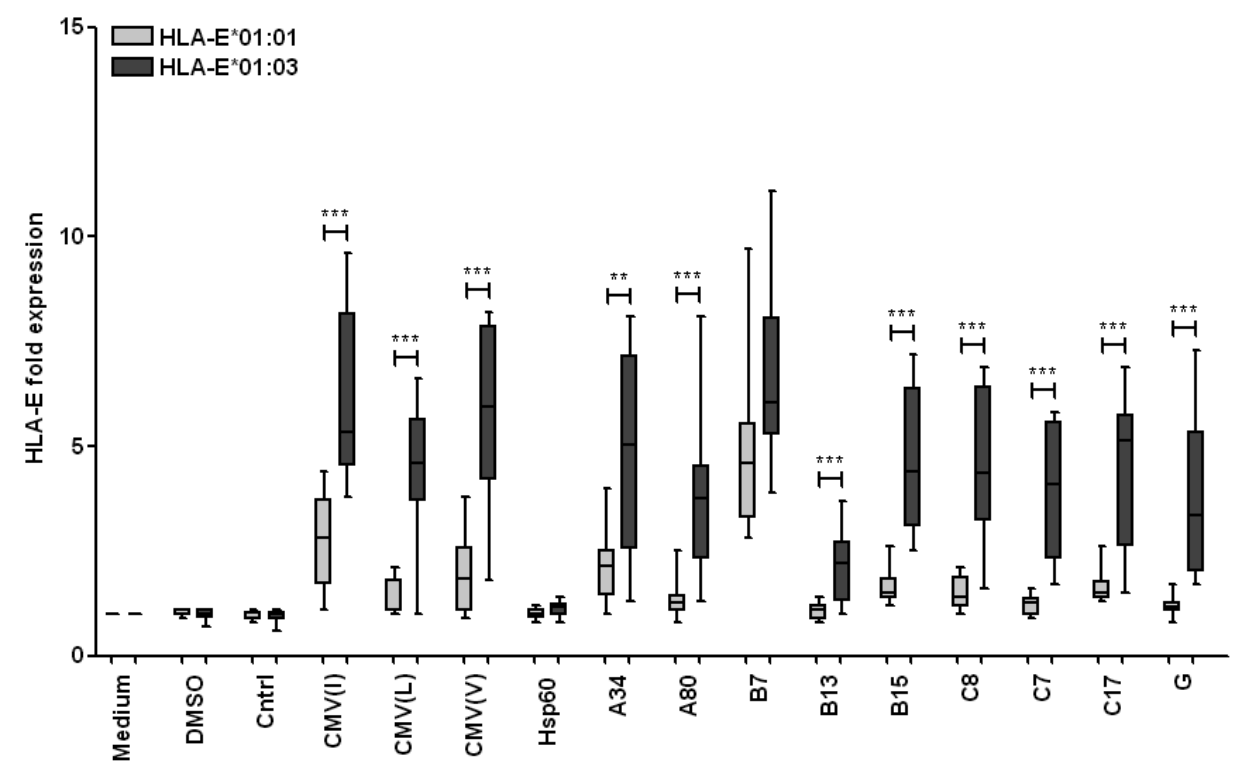

Figure 6.3 Peptide induced HLA-E surface expression is higher in HLA-E*01:03 when compared to HLA$E^{*} 01: 01$. HLA-E surface expression levels in lymphocytes derived from 10 healthy HLA-E*01:01 homozygous subjects (light grey) and 10 healthy HLA-E*01:03 homozygous subjects (dark grey) were analyzed after 14 hours of incubation with various HLA-E binding peptides at $500 \mu \mathrm{M}$ and control conditions (medium, DMSO and control peptide). HLA-E surface expression was analyzed with flow cytometry after gating on lymphocytes (FSC/SCC) and depicted per subject as the fold changes (MFI peptide/MFI medium control). The boxes and whiskers represent the lowest value, highest value, median, 25 th and 75 th percentiles. ${ }^{* *} p<0.01, * * * p<0.001$.

\subsection{Peptide induced HLA-E expression is regulated at post- transcriptional level in PBMCs}

Because HLA-E surface expression started to drop after 6 hours of incubation with peptides (Figure 6.2A+B), we hypothesized that the reduction in HLA-E was due to either exhaustion of the exogenous peptide, or depletion of the endogenous HLA-E storage in the endoplasmatic reticulum. To investigate this hypothesis, PBMC from eight different subjects (four per homozygous genotype) were incubated with two peptides (CMV(I) and B7) that induced high levels of surface HLA-E or two peptides (B13 and C17) that resulted in moderate surface levels of HLA-E in our previous experiment. After 14 hours, new peptides were added to some of the cultures and the cells were incubated for an additional 6 hours. HLA-E surface expression was higher upon 14 hours of incubation with the $\mathrm{CMV}(\mathrm{I}), \mathrm{B} 7, \mathrm{~B} 13$ and $\mathrm{C} 17$ peptides as compared to the control peptide and returned to basal level after an additional 6 hours when peptide was not re-added (Figure 6.4). HLA-E levels remained high when fresh peptide 
was added after the initial 14 hours which suggested that the availability of the peptide, and not of HLA-E itself, became the limiting factor after more than 6 hours of incubation. After re-addition of the peptide, HLA-E levels in HLA-E*01:03 PBMCs were significantly higher as compared to the levels at 14 hours $(\mathrm{CMV}(\mathrm{I}) p<0.01 ; \mathrm{B} 7 p<0.001$; B13 $p<0.05 ;$ C17 $p<0.05)$. In PBMCs homozygous for HLA-E*01:01 the induction after peptide re-addition was comparable to the induction at 14 hours.

\section{Surface}

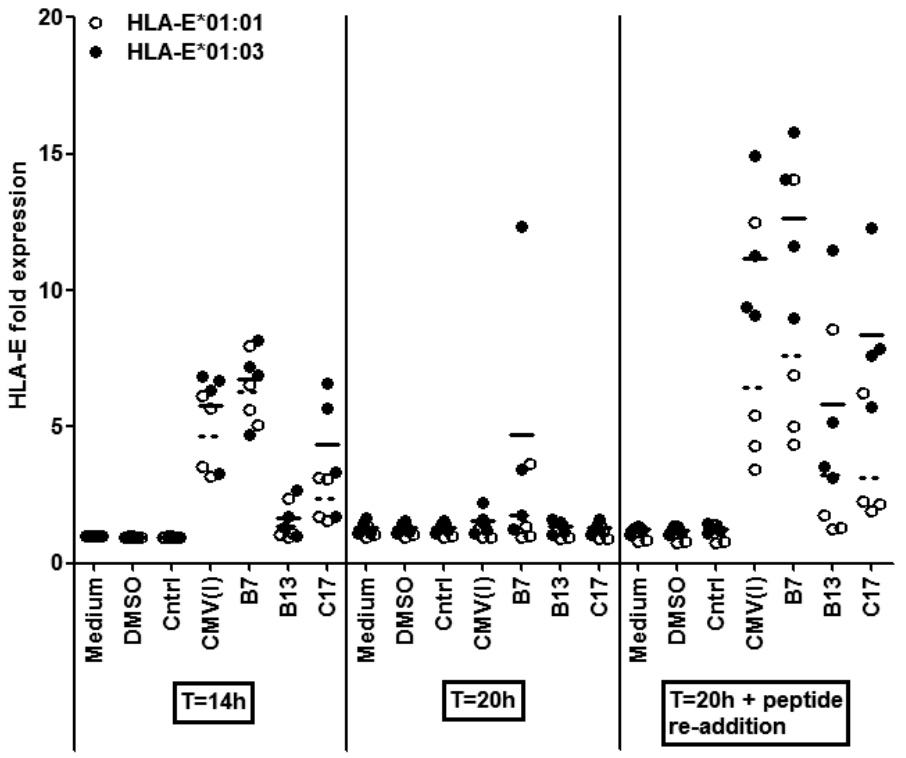

Figure 6.4 Peptide induced HLA-E expression remains high after re-stimulation with peptide. PBMCs derived from 4 healthy HLA-E*01:01 (open circles) and 4 healthy HLA-E*01:03 homozygous subjects (filled circles) were incubated with various HLA-E binding peptides at $500 \mu \mathrm{M}$ or control conditions (medium, DMSO and control peptide) and analyzed for HLA-E surface expression after 14 and 20 hours. To some cultures peptides were re-added at 14 hours and HLA-E surface expression was analyzed at 20 hours. HLA-E surface expression was analyzed with flow cytometry and depicted as fold changes relative to the medium control at 14 hours. Every circle represents a different subject. Dotted horizontal bars correspond to the means of values of the HLA-E*01:01 homozygous subjects and constant horizontal bars correspond to the means of values of HLA-E* 01:03 homozygous subjects.

To examine whether incubation with peptides had triggered HLA-E translation, total cell lysates were prepared of PBMC cultures from two different subjects (homozygous for HLA-E*01:03) that were incubated for 12 hours with the control-, B7- or B13 conserved leader peptide. Total HLA-E protein levels were determined by western blot. In all conditions, an HLA-E specific fragment was present at $43 \mathrm{KDa}$. Densitometric analysis 
showed that this fragment was more abundant in the B7 and B13 conditions than in the medium control and the control peptide. $\beta$-actin was used as loading control and was comparable between the conditions (Figure 6.5A). To further investigate whether HLA-E expression was regulated at translational level, the protein synthesis inhibitor cycloheximide ( $\mathrm{CHX}$ ) was added to some of the cultures during peptide incubation. This resulted in a comparable HLA-E band intensities for all conditions in both subjects, and indicated that total levels of HLA-E did not increase upon incubation with B7 or B13 peptides when translation was inhibited (Figure 6.5A). In addition, we examined whether peptide induced HLA-E surface expression level was also regulated at translational level, by studying the effect of CHX on surface HLA-E with and without peptide stimulation. Here, we showed that without $\mathrm{CHX}, \mathrm{HLA}-\mathrm{E}$ expression was upregulated after incubation with the B7 and B13 peptide when compared to the medium control and the control peptide (Figure 6.5B), which is expected based on our results in Figure 6.3. However, after addition of $\mathrm{CHX}$ the induction of surface HLA-E by the $B 7$ and $B 13$ peptide was significantly impaired when compared to the induction of surface HLA-E by the B7 and B13 peptide without CHX (Figure 6.5B).
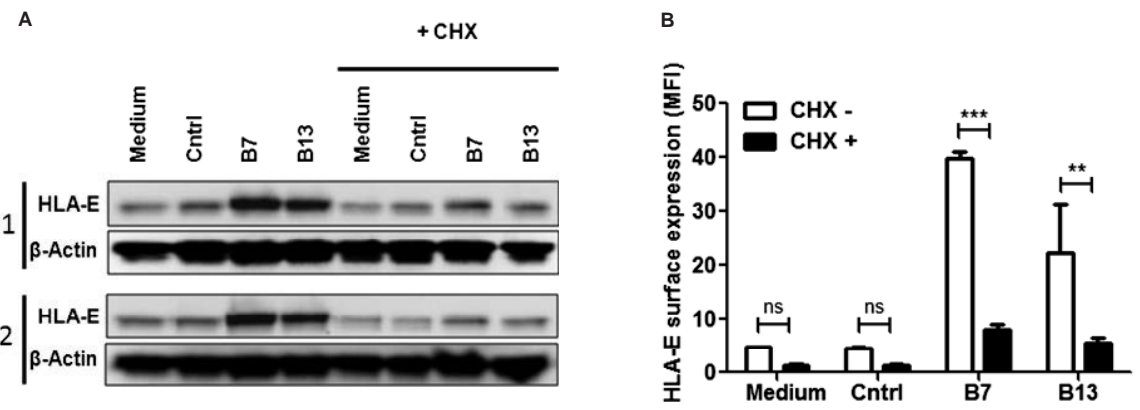

Figure 6.5 HLA-E expression is regulated at post-transcriptional level. PBMCs derived from three healthy subjects were incubated for 14 hours with $500 \mu \mathrm{M}$ B7 or B13 peptide or control conditions (medium and control peptide) with or without addition of Cycloheximide (CHX). A) In cell lysates of two subjects, total HLA-E protein expression levels were determined by western blot. $\beta$-actin was used as loading control. B) In the cells of all three subjects HLA-E surface expression was analyzed with flow cytometry. Data represent mean and SEM of at least 3 different subjects. ${ }^{* *} p<0.01, * * * p<0.001$.

\section{Discussion}

In the present study, we demonstrated with human primary PBMCs that basal and peptide-induced HLA-E surface expression levels are higher in HLA-E*01:03 homozygous PBMCs when compared to HLA-E*01:01 homozygous PBMCs, and that the level of induction was dependent on the peptide sequence. In addition, we show that peptide induced HLA-E expression is regulated at the level of translation. 
Several studies showed that HLA expression by in vitro cultured cell lines is not always representative for primary cells; A first study showed that lymphoblastoid cell lines transformed from the peripheral blood B cells of a Burkitt's lymphoma patient exhibit deviant HLA expression patterns when compared to the original peripheral blood B cells from the same patient ${ }^{28}$. This study also revealed that the patient cells were not recognized by cytotoxic T cells whereas the cell lines were recognized.This difference was attributed to a lower HLA class I expression on the patient cells as compared to the HLA class I expression on the cell lines. A marked difference between in vivo and in vitro HLA expression was also found in a study showing that approximately $30 \%$ of surgically removed melanoma lesions expressed HLA-G protein and mRNA while this was only $1 \%$ in cultured melanoma cell lines ${ }^{30}$. Paco et al. showed that melanoma cell lines which were positive for HLA class I in-vitro, were completely negative for surface HLA class I after injection in various types of mice ${ }^{29}$. Together, these studies illustrate that conclusions based on cell lines could misrepresent the in-vivo situation. Therefore, in the current study experiments were conducted directly in human primary PBMCs.

Our results demonstrate that PBMCs isolated from HLA-E*01:03 individuals express higher levels of HLA-E on the cell surface than PBMCs from HLA-E*01:01 homozygous donors. This difference was observed when HLA-E surface expression was determined directly after isolation but also upon incubation with most of the HLA-E binding peptides. Our data with PBMCs are in agreement with previous studies with BLCL or HLA-E transfected cell lines $8,8,23-27,36,37$. Our data also showed that after peptide restimulation, the HLA-E surface expression level of HLA-E*01:03 was even more induced when compared to the initial peptide stimulation, while in HLA-E*01:01 the induction remained at the same level. Together these data support further studies to unravel the functional relevance of HLA-E polymorphism.

Most of the HLA-E binding peptides in our panel enhanced the level of HLA-E cell surface expression, and for almost all peptides the maximum level of HLA-E was higher in HLA-E*01:03 PBMCs than in HLA-E*01:01 PBMCs. For two peptides, i.e. the B7 and the Hsp60 peptide, the results were clearly different from the results obtained with the other peptides in the panel; Incubation with the B7 peptide resulted in a high HLA-E surface expression, but, in contrast to the other peptides, the HLA-E induction was comparable for both HLA-E*01:01 and HLA-E*01:03 genotypes. This is in concordance to a previous study, where melting transition temperature $(\mathrm{Tm})$ was calculated based on the thermal denaturation of the HLA-E-peptide complex ${ }^{24}$. This showed that the B7 peptide gave similar Tm when bound to either HLA-E*01:01 or HLA-E*01:03. In contrast, Maier et al. ${ }^{9}$ showed in transfected cell lines a higher HLA-E expression level for HLA-E*01:03 as compared to HLA-E*01:01 upon incubation with the B7 peptide. The peptide derived from Hsp60 resulted in a minor and short-term induction of surface HLA-E, whereas the other peptides resulted in a more long term and remarkably stronger induction. A profound HLA-E induction upon incubation with Hsp60 peptide has been shown before in transfected cell lines ${ }^{12}$ and the difference with our data might be the result of using PBMC vs transfected cell lines. As MHC class I 
molecules which are less stable at the cell surface constitutively internalize faster than molecules which are more stable ${ }^{38}$, these results could imply that the HLA-E:Hsp60 complex is a less stable complex than the other HLA-E:peptide complexes. Together these data show that HLA-E surface expression levels are influenced by the HLA-E polymorphism and by the actual sequence of the peptide binding to the HLA-E molecule.

We detected obvious differences in HLA-E surface protein expression levels; between the two HLA-E genotypes and upon incubation with different peptides. However, in none of the experiments we observed a significant difference in HLA-E RNA expression. This fits with the idea that the level of surface HLA-E is mainly regulated through the availability and binding of peptides ${ }^{23}$. Moreover, our data are in line with a recent study showing that selenite can inhibit protein expression whereas RNA levels remained intact $^{39}$, which also indicates regulation of HLA-E at post-transcriptional level. Interestingly, our current data showed that extracellular peptide stimulation triggered the actual synthesis of new HLA-E molecules, and that synthesis was impeded by CHX. This revealed that HLA-E binding peptides regulate HLA-E expression on a translational level as well. The underlying mechanism remains unknown, but previously, ligation of classical HLA class I and II molecules with for example antibodies has been described to trigger intracellular signaling pathways by the association of HLA and signaling molecules $^{40,41}$. Therefore, it is tempting to speculate that, in our system, the binding of peptides to surface HLA-E triggered an intracellular signaling pathway resulting in HLA-E translation. In vivo, this could represent a mechanism by which extracellular peptides enhance the availability of HLA-E molecules. In the physiological condition it has been shown that extracellular peptides can occur upon regurgitation (secretion) of endosomally processed peptides at the cell surface ${ }^{42}$. In that way, neutrophils have been described to process phagocytosed bacteria, regurgitate the peptide and indirectly activate bacterial-specific CD8 T cells after presentation of the regurgitated peptide on $\mathrm{MHC}$ class I of neighboring macrophages ${ }^{43}$. Therefore, it would be very interesting to further investigate if the regulation of HLA-E expression by extracellular peptides could represent a novel way by which HLA-E molecules are made available at the cell surface for presentation to NK or T cells.

In summary our data indicate that, in PBMCs, HLA-E surface expression is higher in HLA-E*01:03 when compared to HLA-E*01:01 and that the level of surface expression is dependent on the peptide sequence. In addition, we demonstrate that peptide-induced HLA-E surface level is not regulated at the transcriptional level, however, we suggest that extracellular available HLA-E binding peptides can enhance translation ensuring stabilization of HLA-E on the surface. Our current study provides further insights in the regulatory properties of HLA-E surface expression, and reveals a potential new regulatory mechanism by extracellular peptides that can be the basis for further functional studies examining the modulatory effects of HLA-E polymorphism and the various peptides on the different NK cell subsets and on T cells. 


\section{References}

1. Pietra G, Romagnani C, Mazzarino P, Falco M, Millo E, Moretta A, Moretta L, Mingari MC. HLA-Erestricted recognition of cytomegalovirus-derived peptides by human CD8+ cytolytic T lymphocytes. Proc Natl Acad Sci U S A. 2003;100:10896-901.

2. Romagnani C, Pietra G, Falco M, Mazzarino P, Moretta L, Mingari MC. HLA-E-restricted recognition of human cytomegalovirus by a subset of cytolytic T lymphocytes. Hum Immunol. 2004;65:437-45.

3. Mazzarino P, Pietra G, Vacca P, Falco M, Colau D, Coulie P, Moretta L, Mingari MC. Identification of effector-memory CMV-specific T lymphocytes that kill CMV-infected target cells in an HLA-E-restricted fashion. Eur J Immunol. 2005;35:3240-7.

4. Kaiser BK, Barahmand-Pour F, Paulsene W, Medley S, Geraghty DE, Strong RK. Interactions between NKG2x immunoreceptors and HLA-E ligands display overlapping affinities and thermodynamics. J Immunol. 2005;174:2878-84.

5. Kaiser BK, Pizarro JC, Kerns J, Strong RK. Structural basis for NKG2A/CD94 recognition of HLA-E. Proc Natl Acad Sci U S A. 2008;105:6696-701.

6. Lee N, Llano M, Carretero M, Ishitani A, Navarro F, López-Botet M, Geraghty DE. HLA-E is a major ligand for the natural killer inhibitory receptor CD94/NKG2A. Proc Natl Acad Sci U S A. 1998;95:5199-204.

7. Braud VM, Allan DS, O'Callaghan CA, Söderström K, D'Andrea A, Ogg GS, Lazetic S, Young NT, Bell Jl, Phillips JH, Lanier LL, McMichael AJ. HLA-E binds to natural killer cell receptors CD94/NKG2A, B and C. Nature. 1998;391:795-9.

8. Lee N, Goodlett DR, Ishitani A, Marquardt H, Geraghty DE. HLA-E surface expression depends on binding of TAP-dependent peptides derived from certain HLA class I signal sequences. J Immunol. 1998;160:4951-60.

9. Maier S, Grzeschik M, Weiss EH, Ulbrecht M. Implications of HLA-E allele expression and different HLA-E ligand diversity for the regulation of NK cells. Hum Immunol. 2000;61:1059-65.

10. Ulbrecht M, Martinozzi S, Grzeschik M, Hengel H, Ellwart JW, Pla M, Weiss EH. Cutting edge: the human cytomegalovirus UL40 gene product contains a ligand for HLA-E and prevents NK cell-mediated lysis. J Immunol. 2000;164:5019-22.

11. Heinzel AS, Grotzke JE, Lines RA, Lewinsohn DA, McNabb AL, Streblow DN, Braud VM, Grieser HJ, Belisle JT, Lewinsohn DM. HLA-E-dependent presentation of Mtb-derived antigen to human CD8+ T cells. J Exp Med. 2002;196:1473-81.

12. Michaelsson J, Teixeira de Matos C, Achour A, Lanier LL, Karre K, Soderstrom K. A signal peptide derived from hsp60 binds HLA-E and interferes with CD94/NKG2A recognition. J Exp Med. 2002;196:1403-14.

13. van Hall T, Oliveira CC, Joosten SA, Ottenhoff TH. The other Janus face of Qa-1 and HLA-E: diverse peptide repertoires in times of stress. Microbes Infect. 2010;12:910-8.

14. Marín R, Ruiz-Cabello F, Pedrinaci S, Méndez R, Jiménez P, Geraghty DE, Garrido F. Analysis of HLA-E expression in human tumors. Immunogenetics. 2003;54:767-75.

15. Geraghty DE, Stockschleader M, Ishitani A, Hansen JA. Polymorphism at the HLA-E locus predates most HLA-A and -B polymorphism. Hum Immunol. 1992;33:174-84.

16. Grimsley C, Ober C. Population genetic studies of HLA-E: evidence for selection. Hum Immunol. 1997;52:33-40.

17. Tamouza R, Rocha V, Busson M, Fortier C, El Sherbini SM, Esperou H, Filion A, Socié G, Dulphy N, Krishnamoorthy R, Toubert A, Gluckman E, Charron D. Association of HLA-E polymorphism with severe bacterial infection and early transplant-related mortality in matched unrelated bone marrow transplantation. Transplantation. 2005;80:140-4.

18. Tamouza R, Busson M, Rocha V, Fortier C, Haddad Y, Brun M, Boukouaci W, Bleux H, Socié G, Krishnamoorthy R, Toubert A, Gluckman E, Charron D. Homozygous status for HLA-E*0103 confers protection from acute graft-versus-host disease and transplant-related mortality in HLA-matched sibling hematopoietic stem cell transplantation. Transplantation. 2006;82:1436-40.

19. Ludajic K, Rosenmayr A, Faé I, Fischer GF, Balavarca Y, Bickeböller H, Kalhs P, Greinix HT. Association of HLA-E polymorphism with the outcome of hematopoietic stem-cell transplantation with unrelated donors. Transplantation. 2009;88:1227-8. 
20. Danzer M, Polin H, Pröll J, Haunschmid R, Hofer K, Stabentheiner S, Hackl C, Kasparu H, König J, Hauser $H$, Binder M, Weiss R, Gabriel C, Krieger O. Clinical significance of HLA-E*0103 homozygosity on survival after allogeneic hematopoietic stem-cell transplantation. Transplantation. 2009;88:528-32.

21. Hosseini E, Schwarer AP, Jalali A, Ghasemzadeh M. The impact of HLA-E polymorphisms on relapse following allogeneic hematopoietic stem cell transplantation. Leuk Res. 2013.

22. Hosseini E, Schwarer AP, Ghasemzadeh M. The impact of HLA-E polymorphisms in graft-versus-host disease following HLA-E matched allogeneic hematopoietic stem cell transplantation. Iran J Allergy Asthma Immunol. 2012;11:15-21.

23. Llano M, Lee N, Navarro F, García P, Albar JP, Geraghty DE, López-Botet M. HLA-E-bound peptides influence recognition by inhibitory and triggering CD94/NKG2 receptors: preferential response to an HLA-G-derived nonamer. Eur J Immunol. 1998;28:2854-63.

24. Strong RK, Holmes MA, Li P, Braun L, Lee N, Geraghty DE. HLA-E allelic variants. Correlating differential expression, peptide affinities, crystal structures, and thermal stabilities. J Biol Chem. 2003;278:5082-90.

25. Miller JD, Weber DA, Ibegbu C, Pohl J, Altman JD, Jensen PE. Analysis of HLA-E peptide-binding specificity and contact residues in bound peptide required for recognition by CD94/NKG2. J Immunol. 2003;171:1369-75.

26. Cheent KS, Jamil KM, Cassidy S, Liu M, Mbiribindi B, Mulder A, Claas FH, Purbhoo MA, Khakoo SI. Synergistic inhibition of natural killer cells by the nonsignaling molecule CD94. Proc Natl Acad Sci U SA. 2013;110:16981-6.

27. Ulbrecht M, Couturier A, Martinozzi S, Pla M, Srivastava R, Peterson PA, Weiss EH. Cell surface expression of HLA-E: interaction with human beta2-microglobulin and allelic differences. Eur J Immunol. 1999;29:537-47.

28. Voltz R, Jilg W, Wolf $\mathrm{H}$. Modification of HLA expression as a possible factor in the pathogenesis of Burkitt's lymphoma. Haematology and blood transfusion. 1989;32:289-92.

29. Paco L, Garcia-Lora AM, Casares C, Cabrera C, Algarra I, Collado A, Maleno I, Garrido F, Lopez-Nevot MA. Total loss of HLA class I expression on a melanoma cell line after growth in nude mice in absence of autologous antitumor immune response. Int J Cancer. 2007;121:2023-30.

30. Chang CC, Murphy SP, Ferrone S. Differential in vivo and in vitro HLA-G expression in melanoma cells: potential mechanisms. Hum Immunol. 2003;64:1057-63.

31. Lauterbach N, Voorter CE, Tilanus MG. Molecular typing of HLA-E. Methods Mol Biol. 2012;882:143-58.

32. Sarkar S, Germeraad WT, Rouschop KM, Steeghs EM, van Gelder M, Bos GM, Wieten L. Hypoxia induced impairment of NK cell cytotoxicity against multiple myeloma can be overcome by IL-2 activation of the NK cells. PLoS ONE. 2013;8:e64835.

33. Pfaffl MW. A new mathematical model for relative quantification in real-time RT-PCR. Nucleic Acids Res. 2001;29:e45.

34. Sui H, Zhou S, Wang Y, Liu X, Zhou L, Yin P, Fan Z, Li Q. COX-2 contributes to P-glycoprotein-mediated multidrug resistance via phosphorylation of c-Jun at Ser63/73 in colorectal cancer. Carcinogenesis. 2011;32:667-75.

35. Paquay MM, Schellekens J, Tilanus MG. A high-throughput Taqman approach for the discrimination of HLA-E alleles. Tissue Antigens. 2009;74:514-9.

36. Brooks AG, Borrego F, Posch PE, Patamawenu A, Scorzelli CJ, Ulbrecht M, Weiss EH, Coligan JE. Specific recognition of HLA-E, but not classical, HLA class I molecules by soluble CD94/NKG2A and NK cells. J Immunol. 1999;162:305-13.

37. Vales-Gomez M, Reyburn HT, Erskine RA, Lopez-Botet M, Strominger JL. Kinetics and peptide dependency of the binding of the inhibitory NK receptor CD94/NKG2-A and the activating receptor CD94/NKG2-C to HLA-E. Embo J. 1999;18:4250-60.

38. Mahmutefendic H, Blagojevic G, Kucic N, Lucin P. Constitutive internalization of murine MHC class I molecules. J Cell Physiol. 2007;210:445-55.

39. Enqvist M, Nilsonne G, Hammarfjord O, Wallin RP, Björkström NK, Björnstedt M, Hjerpe A, Ljunggren HG, Dobra K, Malmberg KJ, Carlsten M. Selenite induces posttranscriptional blockade of HLA-E expression and sensitizes tumor cells to CD94/NKG2A-positive NK cells. J Immunol. 2011;187:3546-54.

40. Skov S. Intracellular signal transduction mediated by ligation of MHC class I molecules. Tissue Antigens. 1998;51:215-23.

41. Al-Daccak R, Mooney N, Charron D. MHC class II signaling in antigen-presenting cells. Curr Opin Immunol. 2004;16:108-13. 
42. Song R, Harding CV. Roles of proteasomes, transporter for antigen presentation (TAP), and beta 2microglobulin in the processing of bacterial or particulate antigens via an alternate class I MHC processing pathway. J Immunol. 1996;156:4182-90.

43. Potter NS, Harding CV. Neutrophils process exogenous bacteria via an alternate class I MHC processing pathway for presentation of peptides to T lymphocytes. J Immunol. 2001;167:2538-46. 


\section{Chapter 7}

\section{HLA-E regulates the NKG2C+NK cell function through presentation of a restricted peptide repertoire}

Nina Lauterbach, Lotte Wieten, Herman E. Popeijus, Christina E.M. Voorter, Marcel G.J. Tilanus 


\section{Abstract}

NK cells interact with the HLA-E molecule via the inhibitory receptor NKG2A and the activating receptor NKG2C. Hence, HLA-E can have a dual role in the immune response. In the present study, we aim to investigate the functional consequences of HLA-E for the NKG2A and NKG2C expressing NK cell subsets by using a panel of HLA-E binding peptides derived from CMV, Hsp60 and HLA class I. PBMC derived from healthy subjects were used as targets to isolated NK cells and NK cell activation was examined by analysis of the expression of the degranulation marker CD107a. Peptide induced HLA-E expression inhibited degranulation of NKG2A+ NK cell subsets with almost all peptides, whereas NKG2A- NKG2C+ NK cell responses were enhanced only after incubation with four peptides; 1.3 fold with $\mathrm{CMV}(\mathrm{I}), \mathrm{A} 80$ and $\mathrm{B} 13$ and 3.2 fold with HLA-G derived peptide. In addition, the HLA-E:G peptide complex triggered NKG2C receptor internalization, as evidenced by a reduction in the percentage of NKG2C+ NK cells when incubated with the peptide, which could be restored by addition of Bafilomycine. In conclusion: In contrast to NKG2A, NKG2C is regulated by HLA-E only when complexed with a restricted peptide repertoire, especiallyin combination with the HLA-G leader peptide. 


\section{Introduction}

NK cells are innate lymphocytes that provide direct lysis of virally-infected, stressed- or transformed cells ${ }^{1}$. Through the production of cytokines, they can also contribute to the shaping of adaptive immune responses ${ }^{2}$. NK cell activation is determined by the integrated balance of signaling via activating and inhibitory receptors ${ }^{3,4}$. One important ligand for NK cell receptors is HLA-E, a non-classical HLA class I molecule ${ }^{5-7}$.

NK cells interact with the HLA-E-peptide complex via C-type lectin-like NKG2 receptor family members ${ }^{8}$. The different NKG2 isoforms pair with CD94 and mediate either an inhibitory (NKG2A/B) or activating (NKG2C/E/H) signal. NKG2A binds with a six fold higher affinity to HLA-E than $N K G 2 C^{6}$ probably to ensure dominance of the inhibitory receptor. Most NK cells in the circulation express inhibitory receptors like killer immunoglobulin like receptors (KIRs) and NKG2A and virtually every normal cell expresses the ligands (HLA-ABC and -E) for these receptors which protects them against lysis by NK cells ${ }^{9,10}$. Virally infected- or malignantly transformed cells on the other hand, frequently express reduced levels of HLA class I and HLA-E while expressing higher levels of activating ligands making them susceptible for NK cells ${ }^{10-12}$.

NKG2A+ NK cell subsets can distinguish self versus non-self by the presence or absence of HLA-E and can eliminate cells expressing low levels of HLA-E ${ }^{9,13}$. The NKG2C+ NK cell subset has been proposed to play a role in viral infection, especially in cytomegalovirus (CMV), and has been shown to expand and enhance their IFN- $\gamma$ producing capacity following CMV infection and reactivation in humans and upon culture with CMVinfected fibroblasts ${ }^{14-19}$. Furthermore, these expanded NKG2C+NK cells have been shown to be characterized by a highly mature phenotype, memory like features and expression CD57, but not NKG2 $A^{16,19,20}$. The exact mechanism driving the expansion of the NKG2C+CD57+ NK cells subsets following CMV infection is unknown and it remains to be investigated whether HLA-E in the context of CMV is the ligand behind this expansion.

The pathophysiological importance of HLA-E is illustrated by the various studies demonstrating that viruses hitchhike the HLA-E system to evade immune surveillance by NK cells ${ }^{10}$. For example, CMV downregulates HLA class I, but, simultaneously encodes several HLA-E binding peptides to guarantee sufficiently high surface expression of HLA-E, resulting in ignorance of CMV infected cells by patrolling NK cells. With respect to cancer, it was shown that high HLA-E expression was correlated with a better survival or prognosis in glio blastoma ${ }^{21}$, colorectal carcinoma ${ }^{22}$, cervical carcinoma $^{23}$ and renal cell carcinoma ${ }^{24}$. Whereas, high HLA-E expression was associated with worse relapse free period in breast carcinoma ${ }^{25}$, with worse survival in ovarian cancer $^{26}$ and with worse prognosis in classical Hodgkin Lymphoma ${ }^{27}$. In addition, HLA-E 
seems to play a role in pregnancy ${ }^{28}$ and autoimmune disease ${ }^{29}$, further emphasizing the relevance of HLA-E in modulating immune responses.

For stable expression on the cell surface HLA-E requires the binding of a restricted set of nonamer peptides ${ }^{30,31}$. These peptides can be derived from the leader sequences of classical HLA class I molecules and HLA-G ${ }^{30,31}$, enabling HLA-E to function as an indirect monitor of HLA class I expression. HLA-E also binds peptides derived from viral-, bacterial- or stress proteins suggesting that HLA-E can be used by T cells and NK cells to broadly monitor for cellular-integrity, -stress, and infection ${ }^{11,32-35}$.

Recent observations that an alteration in the HLA-E peptide repertoire influences NK cell function ${ }^{8,31,36-38}$ illustrate that the interaction between HLA-E and NK cells is more complex than only presence or absence of the HLA-E molecule. Furthermore, HLA-E has a dual role in the immune response, on the one hand as inhibitory ligand for NKG2A+ NK cells and on the other hand as activating ligand for NKG2C+NK cell subsets. In the present study we aimed to compare the functional consequences of HLA-E for the different NK cell subsets using a co-culture system that enabled us to simultaneously determine degranulation of NKG2A+ and NKG2C+ NK cell subsets. First we determined degranulation in response to PBMC targets expressing basal levels of HLA-E. After that, we compared the response of the different NK cell subsets upon incubation with a panel of peptides including all known leader peptides of HLA class I, some CMV peptides and an Hsp60 peptide.

\section{Materials and methods}

\subsection{Cells and donor selection}

PBMCs, which were used as targets to NK cells in the CD107a assays, were derived from heparinized blood from healthy volunteer donors by lymphoprep density gradient centrifugation (Myltenyi). The PBMCs were depleted from NK cells using an on columnsystem with magnetic beads (Myltenyi). Untouched NK cells (CD3-CD56+), which were used as effector cells in the CD107a assays, were obtained using the same on-column system. The volunteer donors were selected after genotyping for Bw4, C1 and C2 by PCR-SSO according to manufacturer's protocol (One Lambda); the target PBMCs missed at least one KIR ligand and the effector NK cells were positive for all three ligands to ensure an activated system. The volunteers donating blood for the target PBMCs were genotyped for HLA-E ${ }^{39}$ and the volunteers homozygous for HLA-E*01:01 or HLA-E*01:03 were selected. Cells were cultured in 96 well-plates in RPMI-1640 with 10\% FCS and 1\% pen/strep (Invitrogen) in a $37^{\circ} \mathrm{C}, 5 \% \mathrm{CO}_{2}$ incubator.

\subsection{Peptide incubation}

The peptides presented in Table 7.1 (Biosythesis Inc.) were used for pre-incubation at $500 \mu \mathrm{M}$ with the target PBMCs $\left(2 * 10^{5}\right.$ in $\left.200 \mu \mathrm{l}\right)$. These peptides represent sequences 
of HLA class I leader peptides, CMV derived peptides (which are identical to HLA class leader peptides but are referred throughout the article as CMV peptides) and Hsp60 peptide. Cells incubated with medium, DMSO (peptide solvent) or non-HLA-E binding control peptide were used as negative controls.

Table 7.1 Peptides used for HLA-E peptide incubation assays.

\begin{tabular}{|c|c|c|}
\hline Name peptide & sequence & Derived from \\
\hline Control peptide & RGPGRAFVTI & (Michaëlsson J. et al. 2002) \\
\hline $\mathrm{CMV}(\mathrm{L})$ & VMAPRTLLL & $\begin{array}{l}\text { HLA-A*01, }-A * 03,-A * 11,-A * 29,-A * 30, A^{*} 31,-A * 32,-A * 33,-A * 36, \\
\text { and } A * 74, H L A-C w 02 \text { and } C C^{*} 15\end{array}$ \\
\hline $\mathrm{CMV}(\mathrm{V})$ & VMAPRTLVL & $\begin{array}{l}\text { HLA-A*02, }-A * 23,-A * 24,-A * 25,-A * 26,-A * 34: 02,-A * 34: 06, \\
-A * 43,-A * 66, \text { and }-A * 69\end{array}$ \\
\hline $\operatorname{CMV}(\mathrm{I})$ & VMAPRTLIL & $\begin{array}{l}\text { HLA-Cw*01, }-C w^{*} 03,-C w^{*} 04,-C w^{*} 05,-C w^{*} 06,-C w^{*} 08 \\
-C w^{*} 12,-C w^{*} 14,-C w^{*} 16 \text { and _Cw*17:02 }\end{array}$ \\
\hline Hsp60(sp) & QMRPVSRVL & Hsp60 \\
\hline A34 & IMAPRTLVL & HLA-A*34:01 \\
\hline A80 & VMPPRTLLL & HLA-A*80 \\
\hline B7 & VMAPRTVLL & $\begin{array}{l}\text { HLA-B*07, }-B^{*} 08,-B^{*} 14,-B^{*} 38,-B * 39,-B * 39,-B * 42,-B 48-B^{*} 67 \\
-B^{*} 73 \text { and }-B^{*} 81\end{array}$ \\
\hline B13 & VTAPRTLLL & $\begin{array}{l}\text { HLA-B*13, -B*18, -B*27, - B*37, -B*40, -B*44, -B*47, -B*54, } \\
B^{*} 55-B^{*} 56,-B * 59,-B * 82 \text { and } B * 83\end{array}$ \\
\hline B15 & VTAPRTVLL & $\begin{array}{l}\text { HLA-B*15, -B35, -B*40, -B*41, -B*44:18, -B*45, -B*46-B*49, } \\
-B^{*} 50,-B * 51,-B * 52,-B * 53,-B * 57,-B * 58 \text { and }-B * 78\end{array}$ \\
\hline $\mathrm{C} 8$ & VMAPRTLTL & $\mathrm{HLA}-\mathrm{CW}^{*} 08: 09$ \\
\hline C7 & VMAPRALLL & HLA-Cw*06:17, $-\mathrm{Cw}^{*} 07$ and $-\mathrm{Cw}^{*} 18$ \\
\hline C17 & VMAPQALLL & HLA-Cw*17:01, Cw*17:03 and $-\mathrm{Cw}^{*} 17: 05$ \\
\hline G & VMAPRTLFL & HLA-G*01 \\
\hline
\end{tabular}

The panel of peptides include one control peptide that is not able to bind to HLA-E, three peptides belonging to various CMV strains (which are identical to leader sequences of various HLA class I alleles), the Hsp60 peptide and peptides derived from all known leader sequences of the different HLA class I alleles.

\subsection{Flow cytometry}

The following mAbs were used: HLA-E (3D12, eBioscience), CD3 (SK7, BD Biosciences), CD56 (B159, BD Biosciences), NKG2A (Z199, Beckman Coulter), NKG2C (FAB138P, R\&D), KIR2DL1 (FAB1844A, R\&D), KIR2DL2/DL3/S2 (DX27, Miltenyi Biotec) and KIR3DL1 (DX9, Miltenyi Biotec). Intracellular staining was performed with the Cytofix/Cytoperm Plus Fixation/permeabilization Kit (BD Biosciences) according to manufacturer's protocol. HLA-E surface expression was analyzed on the FACSCalibur (BD Biosciences) and for functional assays cells were analyzed on a FACSCanto II flow cytometer (BD). All acquired data were analyzed using BD FACSDiva software 6.1.2.

\subsection{CD107a degranulation assay}

PBMCs (depleted from NK cells) and NK cells were separately incubated for 14 hours (unless stated otherwise) with $1000 \mathrm{U} / \mathrm{ml}$ of IL-2 (Proleukin, Novataris Pharma). Subsequently, PBMCs were washed and incubated, at $2 * 10^{5}$ cells per well, with $500 \mu \mathrm{M}$ 
of peptide for 2 hours. Then, $2 * 10^{5}$ NK cells and CD107a Ab (clone) or IgG1 isotype control (BD Biosciences) were added. To some wells also $100 \mathrm{nM}$ Bafilomycine A1 (Sigma-Aldrich) was added. After one hour, Golgi-stop (BD Biosciences) was added. After 12 hours (unless stated otherwise), cells were stained for analysis by flow cytometry on a FACSCanto II flow cytometer (BD) using BD FACSDiva software 6.1.2. Gating strategy is provided as Figure 7.1.
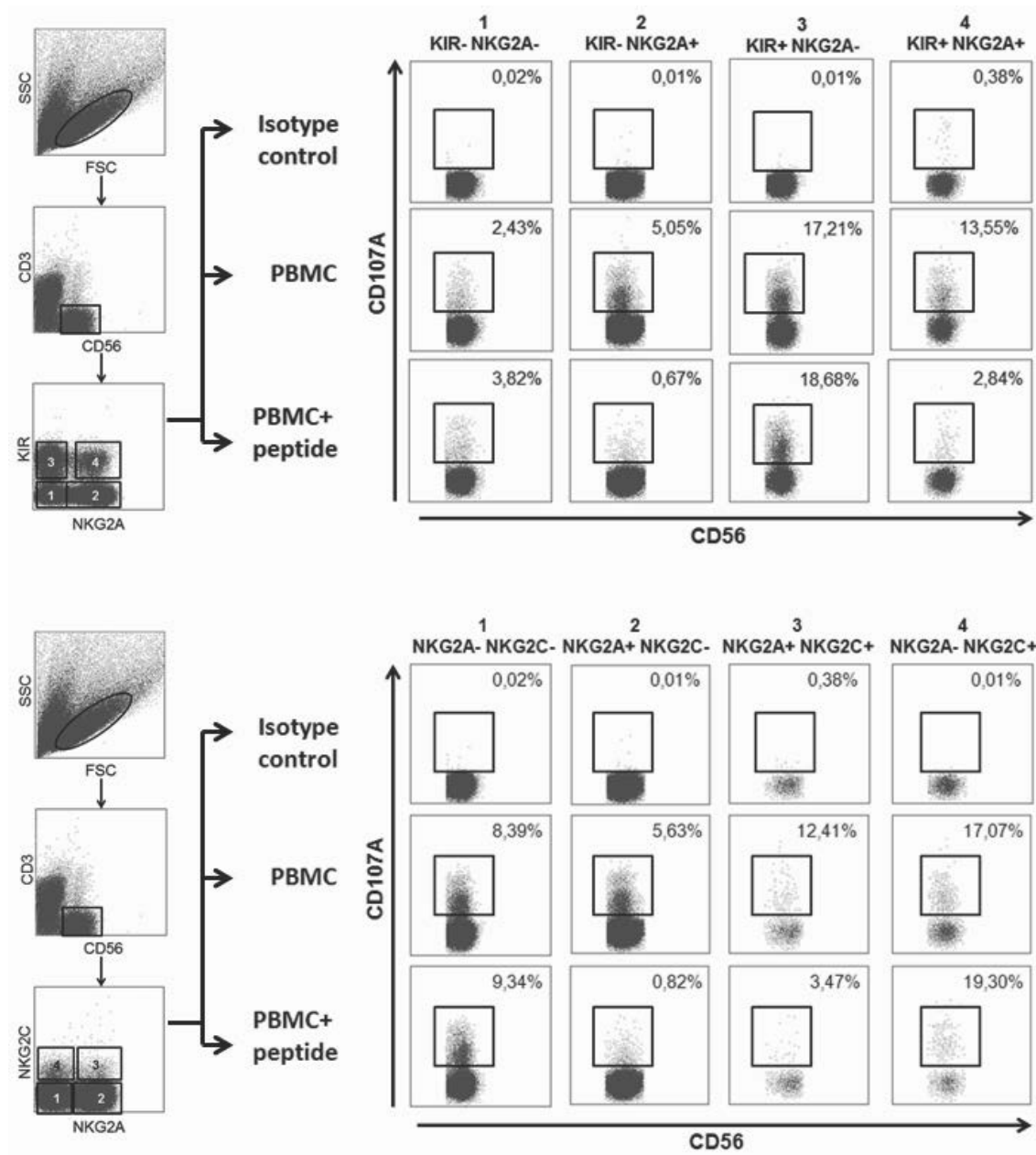

Figure 7.1 Gating strategy NK cell degranulation assay. Lymphocytes were gated based on FCS/SCC. Within the lymphocyte gate CD56+ CD3- cells were selected and further analyzed for various NK cell subsets. In the upper panel, NK cell subsets were defined based on NKG2A and KIR expression, which provided four different subsets (KIR- NKG2A-, KIR- NKG2A+, KIR+ NKG2A-, KIR+ NKG2A+). In the lower panel NK cell subsets were defined based on NKG2A and NKG2C expression, which provided four different subsets (NKG2A- NKG2C-, NKG2A+ NKG2C-, NKG2A+ NKG2C+, NKG2ANKG2C+). Within these different NK cell subsets the percentage of CD56+ CD107A+ cells was determined. As an example percentages of CD56+ CD107A+ cells are shown when incubated with isotype control, PBMCs and PBMCs with $\mathrm{CMV}(\mathrm{L})$ peptide. 


\subsection{Statistics}

Data was analyzed by GraphPad Prism (GraphPad Software, La Jolla, CA, USA) by Student's unpaired two-tailed t-test or two-way ANOVA with bonferroni post-test. A pvalue of below 0.05 was considered significant.

\section{Results}

\subsection{Basal levels of HLA-E on PBMC inhibit degranulation of NKG2A+NK cells but do not influence NKG2C+ NK cells}

To study the functional consequences of basal HLA-E surface expression level on the activation status of NKG2 receptor expressing NK cell subsets, degranulation of NK cells was studied, by means of the marker CD107a, upon co-culture with allogeneic target cells (i.e. PBMC depleted from NK cells) and simultaneous staining for NKG2A/C and for KIR receptors missing HLA. To ensure that the experimental set-up of the CD107a assay would allow us to measure the inhibitory effects of NKG2A-HLA-E interaction, PBMC targets were used that missed at least one NK cell ligand (i.e. Bw4, C1 or C2) and NK effector cells that were licensed for all three ligands. In addition, both the NK cells and the PBMC targets were activated with IL- 2 .

According to the gating strategy depicted in Figure 7.1 the percentage of degranulating $(\mathrm{CD} 107 \mathrm{a}+)$ NK cells was determined in the different subsets upon culture with allogeneic PBMC. This revealed that, as expected based on missing of self HLA class I, the percentage of degranulating NK cells was higher in KIR+ NK cell subsets when compared to the $\mathrm{KIR}^{-}$subsets (Figure 7.1A and 7.2A). The percentage of CD107a+ cells was lowest in subsets that expressed neither KIR nor NKG2A presumably because this subset is hyporesponsive due to the fact they are not licensed. In four out of six subjects KIR+NKG2A+ NK cells degranulated less than KIR+NKG2A-NK cells, however this trend did not reach significance (Figure 7.2A). In one of these four subjects we aimed to confirm that the lower percentage of degranulating NK cells was really caused by the HLA-E expressed by the target cells by blocking HLA-E-NKG2A interaction with an HLA-E specific antibody. This showed that degranulation of KIR+NKG2A+NK cells was enhanced to the level of KIR+NKG2A- subsets in the presence of the HLA-E blocking antibody while there was no effect of HLA-E blocking on the NKG2A-population (Figure 7.2B). Also in the KIR-NKG2A+ subset, the percentage of degranulating NK cells was enhanced by addition of the HLA-E blocking antibody indicating that basal levels of HLA-E inhibit NKG2A expressing NK cells. 
A

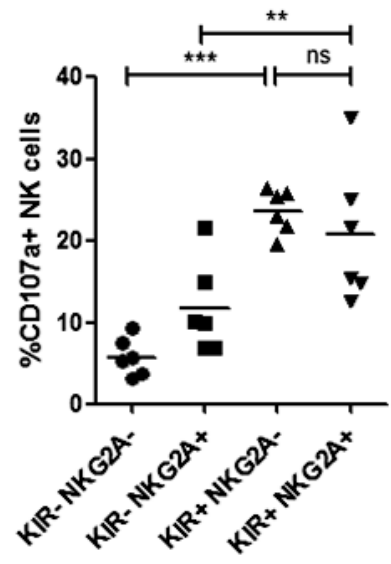

C

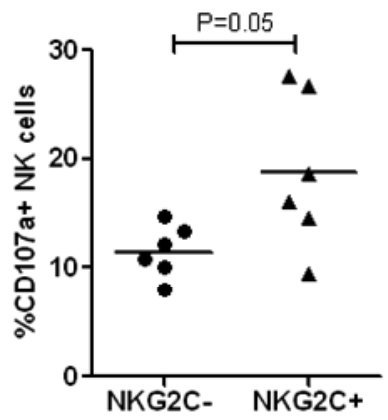

B

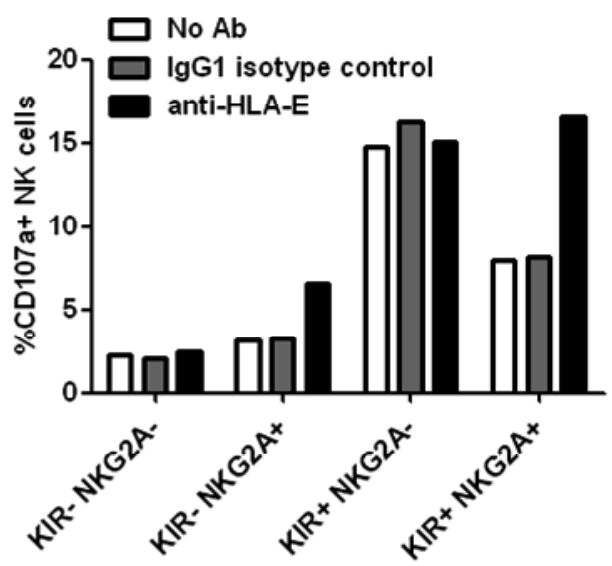

D

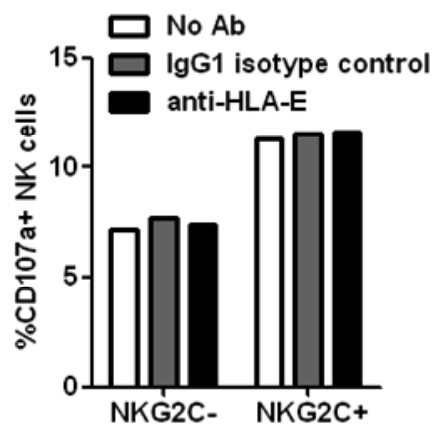

Figure 7.2 NKG2A+ NK cell responses are inhibited by basal HLA-E expression, while NKG2A- NKG2C+ NK cell responses remain unaffected. PBMCs were incubated for 14 hours together with NK cells in the presence of anti-CD107a. Percentage of CD107a+ NK cells subsets based on NKG2A and KIR expression or NKG2A and NKG2C expression were analyzed within the CD3- CD56+ lymphocytes with flow cytometry (for gating strategy see Figure 7.1). Shown are the percentages of CD107a+ cells in the various NK cells subsets based on presence or absence of NKG2A and KIR (A), with anti-HLA-E or isotype control in one subject (B) and the percentages of CD107a+ NKG2A-cells in the various NK cells subsets based on presence or absence of NKG2C (C), with anti-HLA-E or isotype control in one subject (D). Every dot represents one subject. ${ }^{* *} p<0.01,{ }^{* * *} p<0.001$.

To investigate the effect of basal HLA-E expression on NKG2C+ NK cell subsets the response of NKG2C+ and NKG2C- NK cell subsets was compared while NKG2A+ NK cells were excluded from the analysis. Although not significant $(p=0.05)$, there was a trend showing a higher percentage of CD107a+ NK cells in the NKG2C+ subset as compared to the NKG2C- subset (Figure 7.1B and 7.2C). HLA-E blocking with an antibody did not have 
an impact on the percentage of degranulating NK cells, not in the NKG2C- nor in the NKG2C+ subset (Figure 7.2D) suggesting that the enhanced degranulation of NKG2C+ NK cells did not occur in an HLA-E restricted manner.

\subsection{NKG2A+ NK cell responses are inhibited with almost all HLA-E binding peptides, whereas NKG2A- NKG2C+ NK cell activation is solely affected by HLA-E when complexed with a restricted set of peptides}

To study the effect of peptide induced HLA-E expression level on NKG2A+ and $N K G 2 C+N K$ cell activation, the PBMC target cells were incubated with a panel of HLA-E binding peptides including peptides derived from HLA class I and HLA-G leader peptides and an Hsp60 peptide (Table 7.1). We previously showed that all these peptides, except for the Hsp60 peptide, enhanced HLA-E cell surface expression (Lauterbach et al. manuscript submitted). Also in the present study, HLA-E levels, depicted as fold expression relative to the medium control, were enhanced upon 14 hours of incubation with HLA-E binding peptides as compared to incubation with the control peptide while the levels with Hsp60 peptide remained unchanged (Figure 7.3).

\section{HLA-E expression}

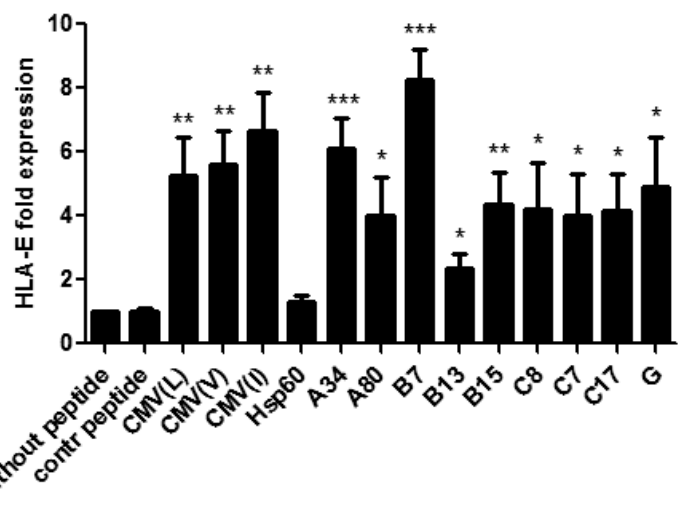

Figure 7.3 Peptide induced HLA-E surface expression in the PBMCs used as target in the CD107a assays. HLA-E surface expression levels in lymphocytes derived from 6 healthy subjects were analyzed after 14 hours of incubation with various HLA-E binding peptides at $500 \mu \mathrm{M}$ and control conditions (medium, DMSO and control peptide). HLA-E surface expression was analyzed with flow cytometry after gating on lymphocytes (FSC/SCC) and depicted per subject as the fold changes (MFI peptide/MFI medium control). The bars represent mean and SEM of 6 subjects. ${ }^{*} p<0.05,{ }^{* *} p<0.01,{ }^{* * *} p<0.001$. P values are calculated as compared to the control peptide.

To examine the effect of peptide-induced HLA-E expression on NKG2A+ and NKG2C+NK cells, the CD107a assay described above was used and PBMC pre-incubated for two hours with the peptides were used as targets. This demonstrated that degranulation of 
NKG2A+ NK cell subsets (KIR-NKG2A+ and KIR+NKG2A+) but not of NKG2A- subsets (KIR-NKG2A- or KIR+NKG2A-) was significantly decreased by incubation of the target with either one of the three CMV peptides as compared to control conditions (Figure 7.4A). In line with the low induction of cell surface HLA-E by the Hsp60 peptide, the percentage of CD107a+ NK cells was not influenced by the Hsp60 peptide in any of the four subsets (Figure 7.4A). Degranulation of NKG2A+ NK cells was also inhibited by all HLA class I leader peptides except the C17 peptide, and again the response of NKG2Asubsets remained unchanged. The level of inhibition was comparable for all peptides, regardless of whether the peptide induced high or low HLA-E expression. The only exception was the C17 peptide that induced a high level of cell surface HLA-E while it had no effect on degranulation of NKG2A+ NK cell subsets (Figure 7.4A).

Also the impact of peptide-induced HLA-E on NKG2C+ NK cells was studied. While almost all peptides in the panel enhanced HLA-E surface expression, only four of these peptides influenced the NKG2C+ NK cell activation level (Fig. 4B); CMV(I), A80 and B13 peptides slightly enhanced the percentage of CD107a+ NKG2C+NK cells when compared to the control peptide. Interestingly, incubation of the PBMCs with HLA-G peptide resulted in a more pronounced (threefold) increase in degranulation of NKG2C+ NK cells. None of the peptides enhanced or inhibited degranulation of NKG2CNK cells.

\subsection{The HLA-E:G peptide complex induces internalization of the NKG2C receptor}

In addition to augmented degranulation of NKG2C+ NK cells, a decrease in the percentage of NKG2C+NK cells was observed upon incubation with the HLA-G peptide (mean $4.68 \pm 0.96$ vs $1.34 \pm 0.38$ ) (Figure $7.5 \mathrm{~A}$ ) while this was not observed for any of the other peptides (data not shown) and was absent for the NKG2A+ NK cells (Figure 7.5B). To study whether this decrease in the percentage of NKG2C+ NKG2A- NK cells was due to internalization of the $\mathrm{NKG} 2 \mathrm{C}$ receptor, the fold reduction in the percentage of $\mathrm{NK}$ cells expressing NKG2C on the cell surface was determined, and intra-cellular staining for NKG2C was performed to also take into account internalized NKG2C molecules (total NKG2C). Both the percentage of surface NKG2C+ NK cells and the percentage of total NKG2C+ NK cells were decreased by incubation with the G peptide (Figure 7.5C). This decrease was at least partly restored by addition of an HLA-E blocking Ab to the cocultures. To avoid lysosomal degradation of internalized NKG2C molecules Bafilomycin was added to some cultures. Bafilomycin did not influence the percentage of cell surface NKG2C+ NK cells. However, it enhanced the percentage of total NKG2C+NK cells (both intracellular and cell surface) which suggests that NKG2C was indeed at least partly internalized and degraded upon interaction with the HLA-E:HLA-G peptide complex (Figure 7.5C). 
A
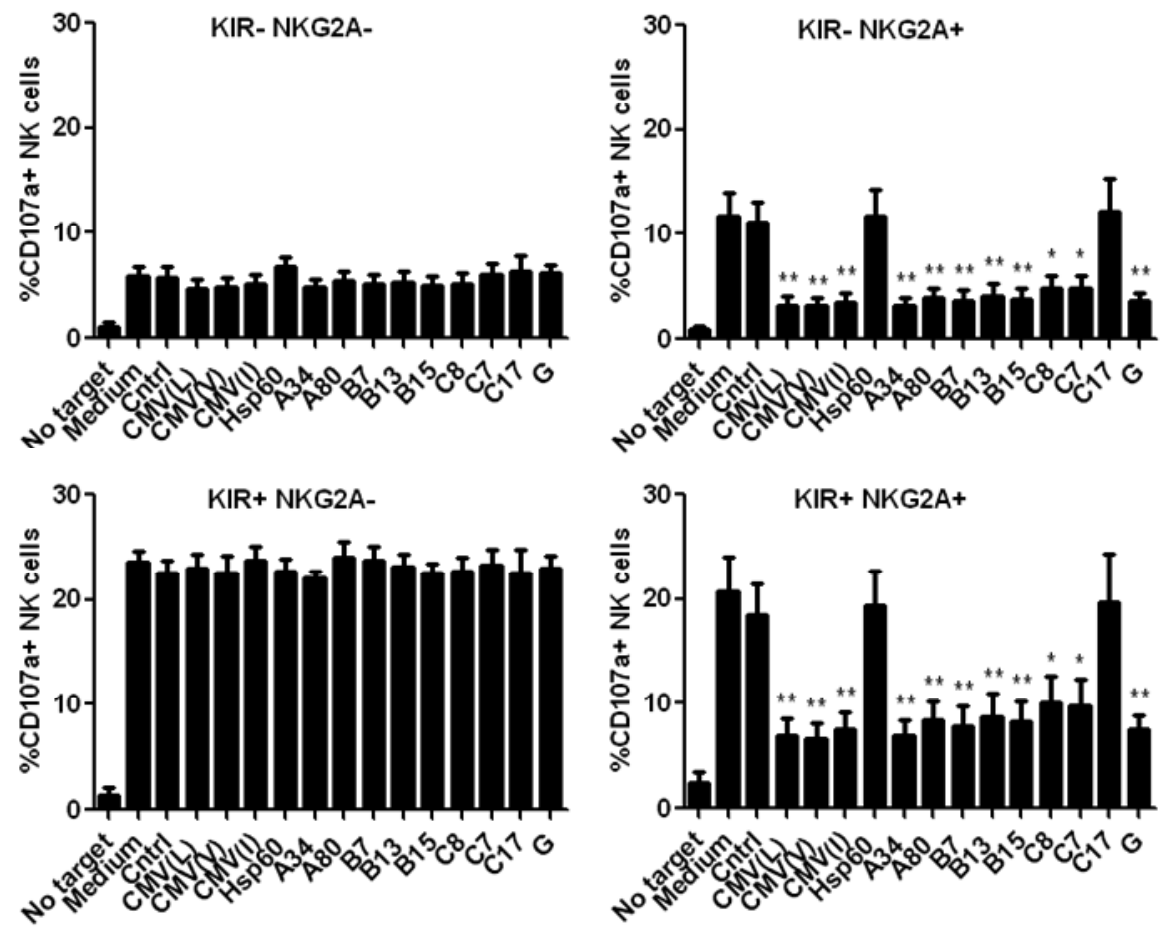

B
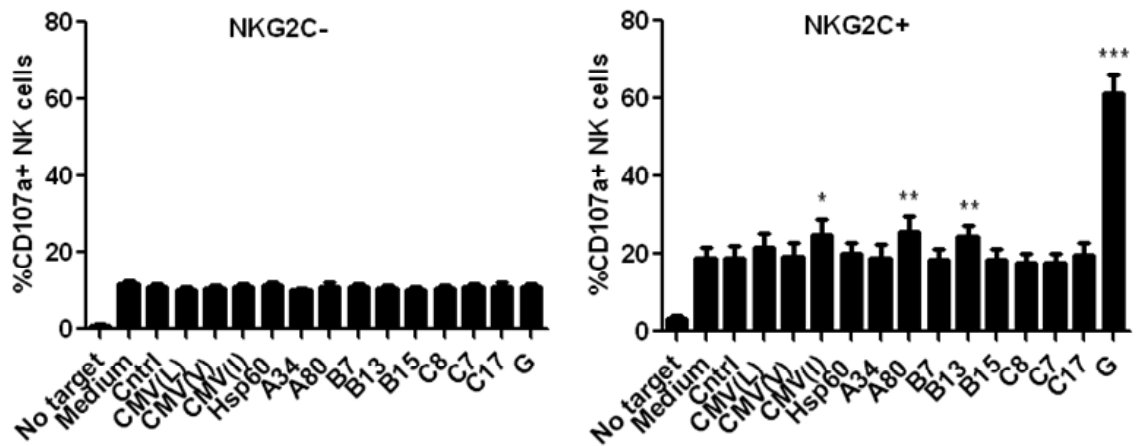

Figure 7.4 NKG2A+ NK cell responses are inhibited with almost all peptides, while NKG2A- NKG2C+ NK cell responses are solely induced with specific HLA-E/peptide combinations. Experimental details regarding the CD107a assay are identical to Figure 7.2, except that the PBMCs were preincubated for 2 hours with the various peptides. Shown are the percentages of CD107a+ cells in the NK cell subsets based on presence or absence of NKG2A and KIR (A) and the percentages of CD107a+ NKG2A- cells in the NK cell subsets based on presence or absence of NKG2C (B). Bars represent mean and SEM of 6 different subjects. ${ }^{*} p<0.05,{ }^{* *} p<0.01,{ }^{* * *} p<0.001$. P values are calculated as compared to medium. 
A

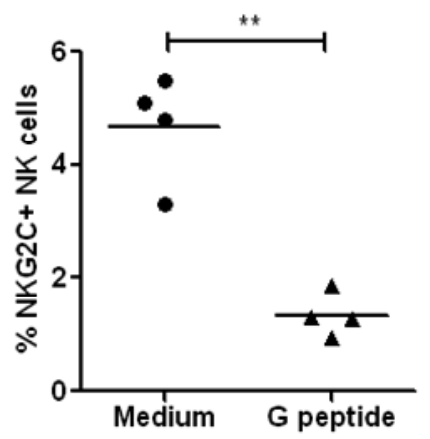

B

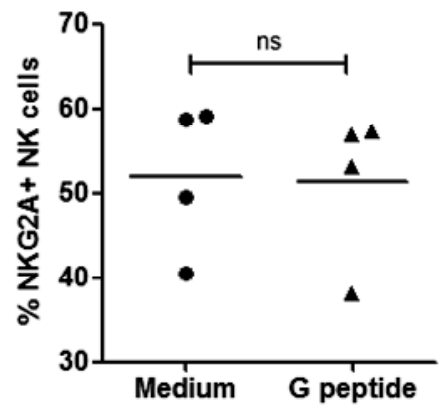

C

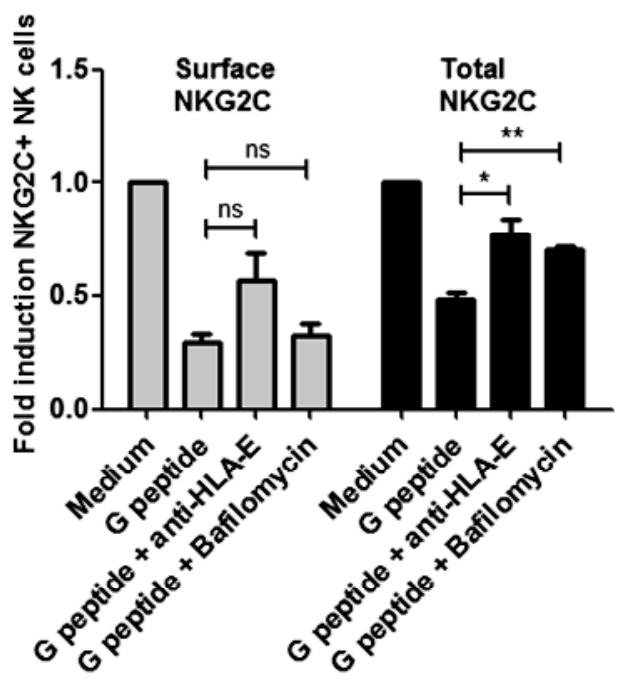

Figure 7.5 The percentage of NKG2C expressing NK cells is decreased upon incubation with HLA-G derived leader peptide. PBMCs were pre-incubated for 2 hours with or without $\mathrm{G}$ peptide or medium control, where after NK cells in the presence or absence of Bafilomycine or anti-HLA-E were added and further incubated for 4 hours. Cells were stained for NKG2C and analyzed by flow cytometry. Shown is A) the percentage of NKG2C+ cells B) the percentage of NKG2A+ cells C) the fold change of percentage of cells stained for surface NKG2C (left panel) and stained for surface + intracellular NKG2C (total) (right panel). In A and B every dot represents one donor. In C, fold percentages of CD56+ NKG2C+ cells relative to medium are depicted. Bars represent mean and SEM of at least 3 different donors. ${ }^{*} p<0.05,{ }^{* *} p<0.01$, ns $=$ not significant. 


\section{Discussion}

In the present study, we investigated the functional consequences of basal and peptide induced HLA-E expression for the NKG2A+ NK cell subsets when compared to the NKG2C+NKG2A- NK cells. Our results show that the low level of basal HLA-E on IL-2 activated PBMC already provided an inhibitory signal for NKG2A+ NK cells which could be enhanced by up-regulation of HLA-E by most of the HLA-E binding peptides. In contrast, basal levels of HLA-E did not trigger NKG2C+ NK cell responses, and peptide induced HLA-E expression enhanced NKG2C+ NK cell activation only in association with four of the peptides, demonstrating that for the NKG2C+NK cell subset this was clearly different than for the NKG2A+ NK cell subset.

Some of the peptides in our panel induced a relatively high (e.g. B7 and CMV(I)) or low (B13) level of surface HLA-E. However, a higher expression of HLA-E did not lead to more inhibition of NKG2A+ NK cell degranulation and a lower expression of HLA-E did not lead to less inhibition of NKG2A+ NK cell degranulation. Furthermore, in another study we showed that HLA-E is higher expressed in HLA-E*01:03 homozygous PBMCs when compared to HLA-E*01:01 homozygous PBMCs (N. Lauterbach et al. manuscript submitted). Grouping the PBMCs based upon HLA-E genotype, revealed that NK cell degranulation against HLA-E*01:01 homozygous PBMCs was comparable to responses against HLA-E*01:03 homozygous PBMCs. Therefore, our results suggest that there is no linear relation between the HLA-E expression level and NK cell inhibition of NKG2A+ NK cells. Rather, our findings illustrate that above a certain threshold a higher level of HLA-E has no additive inhibitory effect. This observation is in line with a recent study where they showed that inhibition of NK cells by MHC class I exhibited saturation kinetics for NKG2A+ NK cells, whereas inhibition based on KIR interaction was linear ${ }^{40}$. This implies that NKG2A+ NK cells can respond better to variations in the level of surface HLA-E when expression is low than when HLA-E surface expression is high.

From our study it becomes clear that the sequence of the peptide bound to HLA-E determined the magnitude of NKG2A+ NK cell degranulation, confirming previous studies with HLA-E expressing cell lines ${ }^{8,31,36-38}$. The effect of the peptide was most obvious for the C17 peptide where the level of NKG2A+ NK cell degranulation remained high despite of the high HLA-E expression level. The C17 peptide is the only peptide in our panel expressing a Gln at position 5. Previously, a mutation at this position has been described to abrogate the interaction with NKG2A ${ }^{34,37,40}$. Like C17 in our system, the Hsp60 peptide lacked the inhibitory effect on NKG2A+ NK cells. Most likely, this was the consequence of the relatively low and short lived HLA-E induction in our system. On the other hand, the Hsp60 peptide itself and stress-induced upregulation of endogenous Hsp60 have been demonstrated to enhance surface HLA-E without inhibiting NK cells ${ }^{34}$. Probably, this represents a mechanism for NK cells to detect and respond to stressed cells. Also, peptides with a Thr at position 2 have been reported to 
lack inhibitory effects even though they enhanced HLA-E expression ${ }^{8,31,36}$. In our system these peptides (B13 and B15) did inhibit NKG2A+ NK cell degranulation which is in agreement with two previous studies showing binding of HLA-E complexed with these peptides to the NKG2A receptor and inhibition of NK cell lysis ${ }^{38,41}$. The discrepancy between the different studies could be due to the experimental set-up; our study and Brooks et al. ${ }^{38}$ used a high peptide concentration $(300-500 \mu \mathrm{M})$ whereas the studies showing no inhibition used a low peptide concentration (max. $100 \mu \mathrm{M}$ ). The other studies used soluble HLA-E peptide complexes ${ }^{8,31,36,41}$. It has been suggested that the higher amount of peptide compensates for the lower peptide binding affinity ${ }^{41}$.

The effect of HLA-E on NKG2C+ NK cell subsets was clearly different from the impact on NKG2A expressing NK cells; HLA-E in complex with almost all peptides inhibited NKG2A+ subsets, but, only four (i.e. $\operatorname{CMV}(I), A 80, B 13$ and $G$ peptide) of the thirteen peptides enhanced degranulation of NKG2A-NKG2C+NK cells. Of these four, only the HLA-G peptide caused a potent increase in degranulation of NKG2C+ NK cells, which is in line with previous studies ${ }^{36,37,41}$. Interestingly, this induction of degranulation coincited with internalization of the NKG2C receptor. We did not observe this phenomenon for any of the other peptides or for the NKG2A receptor. Previously, NKG2A levels have been shown to remain constant upon ligation ${ }^{42}$ which is probably important to maintain a stable level of inhibitory receptors to avoid unwanted NK cell reactivity. For some activating receptors, i.e. NKG2D and CD3 $\gamma$, internalization upon prolonged ligand interaction has been described ${ }^{43,44}$. NKG2C possesses the dileucine motif (DxxxLL) known to target CD3y for lysosmoal degradation ${ }^{42,45}$. Our observation that bafilomycin, a lysosomal inhibitor, prevented degradation of internalized NKG2C, suggests that NKG2C internalization and degradation could occur in a way comparable to that of CD3ץ. Presumably, the downregulation of activating receptors like NKG2C might represent a physiological mechanism to avoid excessive NK cell reactivity.

This study shows that peptides present in-vivo, e.g. the HLA class I leader peptides, do not have a major impact on NKG2C+ NK cells while they can inhibit NKG2A+ NK cells. Only the HLA-G leader peptide was able to provoke a potent response in the NKG2ANKG2C+ NK cell subset. Under normal conditions, HLA-G is not expressed on the cell surface but expression can be enhanced in virally infected cells ${ }^{46-48}$. Interestingly, HLA-G is also upregulated during HCMV infection and reactivation ${ }^{48,49}$. HCMV associated expansion of NKG2C+CD57+ NK cells with memory-like characteristics has been observed after stem cell and solid organ transplantation ${ }^{16-20,50}$. During pregnancy, decidual NK cells, which are normally mainly producers of cytokines/chemokines and angiogenic factors, obtain more cytotoxic features following CMV infection due to upregulation of $\mathrm{NKG} 2 \mathrm{C}^{51}$. The ligand driving the expansion of the NKG2C+ subset is unknown, but, based on our results HLA-E in complex with the HLA-G peptide could be an interesting candidate. Various viruses, amongst them CMV, inhibit TAP functioning. In TAP-deficient cells, HLA-E has been shown to present a completely new set of 
peptides binding at a lower affinity than the TAP-dependent peptides ${ }^{52}$. It would be interesting to test whether HLA-E in complex with these "TAP-deficient" peptides has the same potential to activate NKG2C+ NK cells as HLA-E in complex with the HLA-G peptide.

In summary the present study demonstrates that HLA-E regulates NKG2A+ and NKG2C+ NK cell subsets in a different manner. While basal HLA-E expression levels are sufficient to inhibit activation of NKG2A+ NK cells, they do not influence the activation status of NKG2C+ NK cells. Moreover, HLA-E in complex with an HLA class I leader peptide provides a strong inhibitory signal for NKG2A+ NK cells while it has only a minor activating effect on NKG2C+ subsets. Our data demonstrates that HLA-E will only act as a potent activating ligand for NKG2C+ cells when it is complexed to the HLA-G leader peptide. It should be kept in mind that for example during viral infection, HLA-G is upregulated and the leader peptide can become increasingly available enabling HLA-E to activate NKG2C+ NK cells. Our data also show that HLA-E:G interaction with NKG2C subsequently leads to the internalization of the receptor while the inhibitory receptor remains present which could represent an additional mechanism to avoid excessive autoreactivity. Hence, by presentation of the different peptides, HLA-E might act as a cellular-sensor balancing NK cell immunity between unwanted autoreactivity and a potent response against stressed-, necrotic-, virally infected or tumor cells. 


\section{References}

1. Moretta L, Moretta A. Unravelling natural killer cell function: triggering and inhibitory human NK receptors. EMBO J. 2004;23:255-9.

2. Martín-Fontecha A, Thomsen LL, Brett S, Gerard C, Lipp M, Lanzavecchia A, Sallusto F. Induced recruitment of NK cells to lymph nodes provides IFN-gamma for T(H)1 priming. Nat Immunol. 2004;5: 1260-5.

3. Bottino C, Castriconi R, Moretta L, Moretta A. Cellular ligands of activating NK receptors. Trends in immunology. 2005;26:221-6.

4. Ljunggren HG, Karre K. In search of the 'missing self': MHC molecules and NK cell recognition. Immunol Today. 1990;11:237-44.

5. Kaiser BK, Barahmand-Pour F, Paulsene W, Medley S, Geraghty DE, Strong RK. Interactions between NKG2x immunoreceptors and HLA-E ligands display overlapping affinities and thermodynamics. J Immunol. 2005;174:2878-84.

6. Kaiser BK, Pizarro JC, Kerns J, Strong RK. Structural basis for NKG2A/CD94 recognition of HLA-E. Proc Natl Acad Sci U S A. 2008;105:6696-701.

7. Lee N, Llano M, Carretero M, Ishitani A, Navarro F, López-Botet M, Geraghty DE. HLA-E is a major ligand for the natural killer inhibitory receptor CD94/NKG2A. Proc Natl Acad Sci U S A. 1998;95:5199-204.

8. Braud VM, Allan DS, O'Callaghan CA, Söderström K, D'Andrea A, Ogg GS, Lazetic S, Young NT, Bell Jl, Phillips JH, Lanier LL, McMichael AJ. HLA-E binds to natural killer cell receptors CD94/NKG2A, B and C. Nature. 1998;391:795-9.

9. Iwaszko M, Bogunia-Kubik K. Clinical significance of the HLA-E and CD94/NKG2 interaction. Arch Immunol Ther Exp (Warsz). 2011;59:353-67.

10. Lodoen MB, Lanier LL. Viral modulation of NK cell immunity. Nat Rev Microbiol. 2005;3:59-69.

11. Marín R, Ruiz-Cabello F, Pedrinaci S, Méndez R, Jiménez P, Geraghty DE, Garrido F. Analysis of HLA-E expression in human tumors. Immunogenetics. 2003;54:767-75.

12. Morgado S, Sanchez-Correa B, Casado JG, Duran E, Gayoso I, et al. NK cell recognition and killing of melanoma cells is controlled by multiple activating receptor-ligand interactions. Journal of Innate Immunity. 2011;3:365-73.

13. Rodgers JR, Cook RG. MHC class Ib molecules bridge innate and acquired immunity. Nat Rev Immunol. 2005;5:459-71.

14. Gumá M, Angulo A, Vilches C, Gómez-Lozano N, Malats N, López-Botet M. Imprint of human cytomegalovirus infection on the NK cell receptor repertoire. Blood. 2004;104:3664-71.

15. Gumá M, Budt M, Sáez A, Brckalo T, Hengel H, Angulo A, López-Botet M. Expansion of CD94/NKG2C+ NK cells in response to human cytomegalovirus-infected fibroblasts. Blood. 2006;107:3624-31.

16. Lopez-Vergès S, Milush JM, Schwartz BS, Pando MJ, Jarjoura J, York VA, Houchins JP, Miller S, Kang SM, Norris PJ, Nixon DF, Lanier LL. Expansion of a unique CD57NKG2Chi natural killer cell subset during acute human cytomegalovirus infection. Proc Natl Acad Sci U S A. 2011;108:14725-32.

17. Muñoz-Cobo B, Solano C, Benet I, Costa E, Remigia MJ, de la Cámara R, Nieto J, López J, Amat P, GarciaNoblejas A, Bravo D, Clari MÁ, Navarro D. Functional profile of cytomegalovirus (CMV)-specific CD8(+) T cells and kinetics of $\mathrm{NKG} 2 \mathrm{C}(+) \mathrm{NK}$ Cells associated with the resolution of CMV DNAemia in allogeneic stem cell transplant recipients. J Med Virol. 2012;84:259-67.

18. Béziat V, Dalgard O, Asselah T, Halfon P, Bedossa P, Boudifa A, Hervier B, Theodorou I, Martinot M, Debré P, Björkström NK, Malmberg KJ, Marcellin P, Vieillard V. CMV drives clonal expansion of NKG2C+ NK cells expressing self-specific KIRs in chronic hepatitis patients. Eur J Immunol. 2012;42:447-57.

19. Foley B, Cooley S, Verneris MR, Curtsinger J, Luo X, Waller EK, Anasetti C, Weisdorf D, Miller JS. Human cytomegalovirus (CMV)-induced memory-like NKG2C(+) NK cells are transplantable and expand in vivo in response to recipient CMV antigen. J Immunol.2012;189:5082-8.

20. Della Chiesa M, Muccio L, Moretta A. CMV induces rapid NK cell maturation in HSCT recipients. Immunology letters. 2013.

21. Kren L, Slaby O, Muckova K, Lzicarova E, Sova M, Vybihal V, Svoboda T, Fadrus P, Lakomy R, Vanhara P, Krenova Z, Sterba J, Smrcka M, Michalek J. Expression of immune-modulatory molecules HLA-G and HLA-E by tumor cells in glioblastomas: an unexpected prognostic significance? Neuropathology. 2011; 31:129-34. 
22. Benevolo M, Mottolese M, Tremante E, Rollo F, Diodoro MG, Ercolani C, Sperduti I, Lo Monaco E, Cosimelli M, Giacomini P. High expression of HLA-E in colorectal carcinoma is associated with a favorable prognosis. J Trans/ Med. 2011;9:184.

23. Spaans VM, Peters AA, Fleuren GJ, Jordanova ES. HLA-E expression in cervical adenocarcinomas: association with improved long-term survival. J Transl Med. 2012;10:184.

24. Kren L, Valkovsky I, Dolezel J, Capak I, Pacik D, Poprach A, Lakomy R, Redova M, Fabian P, Krenova Z, Slaby O. HLA-G and HLA-E specific mRNAs connote opposite prognostic significance in renal cell carcinoma. Diagn Pathol. 2012;7:58.

25. de Kruijf EM, Sajet A, van Nes JG, Natanov R, Putter H, Smit VT, Liefers GJ, van den Elsen PJ, van de Velde CJ, Kuppen PJ. HLA-E and HLA-G expression in classical HLA class I-negative tumors is of prognostic value for clinical outcome of early breast cancer patients. J Immunol. 2010;185:7452-9.

26. Gooden M, Lampen M, Jordanova ES, Leffers N, Trimbos JB, van der Burg SH, Nijman H, van Hall T. HLAE expression by gynecological cancers restrains tumor-infiltrating CD8 T lymphocytes. Proc Natl Acad Sci U S A. 2011;108:10656-61.

27. Kren L, Fabian P, Slaby O, Janikova A, Soucek O, Sterba J, Krenova Z, Michalek J, Kral Z. Multifunctional immune-modulatory protein HLA-E identified in classical Hodgkin lymphoma: possible implications. Pathol Res Pract. 2011;208:45-9.

28. Tripathi P, Naik S, Agrawal S. HLA-E and immunobiology of pregnancy. Tissue Antigens 2006;67:207-13.

29. Prigione I, Penco F, Martini A, Gattorno M, Pistoia V, Morandi F. HLA-G and HLA-E in patients with juvenile idiopathic arthritis. Rheumatology (Oxford). 2010;50:966-72.

30. Lee N, Goodlett DR, Ishitani A, Marquardt H, Geraghty DE. HLA-E surface expression depends on binding of TAP-dependent peptides derived from certain HLA class I signal sequences. J Immunol. 1998;160:4951-60.

31. Maier S, Grzeschik M, Weiss EH, Ulbrecht M. Implications of HLA-E allele expression and different HLA-E ligand diversity for the regulation of NK cells. Hum Immunol. 2000;61:1059-65.

32. Ulbrecht M, Martinozzi S, Grzeschik M, Hengel H, Ellwart JW, Pla M, Weiss EH. Cutting edge: the human cytomegalovirus UL40 gene product contains a ligand for HLA-E and prevents NK cell-mediated lysis. J Immunol. 2000;164:5019-22.

33. Heinzel AS, Grotzke JE, Lines RA, Lewinsohn DA, McNabb AL, Streblow DN, Braud VM, Grieser HJ, Belisle JT, Lewinsohn DM. HLA-E-dependent presentation of Mtb-derived antigen to human CD8+ T cells. J Exp Med. 2002;196:1473-81.

34. Michaëlsson J, Teixeira de Matos C, Achour A, Lanier LL, Kärre K, Söderström K. A signal peptide derived from hsp60 binds HLA-E and interferes with CD94/NKG2A recognition. J Exp Med. 2002;196:1403-14.

35. van Hall T, Oliveira CC, Joosten SA, Ottenhoff TH. The other Janus face of Qa-1 and HLA-E: diverse peptide repertoires in times of stress. Microbes Infect. 2010;12:910-8.

36. Llano M, Lee N, Navarro F, García P, Albar JP, Geraghty DE, López-Botet M. HLA-E-bound peptides influence recognition by inhibitory and triggering CD94/NKG2 receptors: preferential response to an HLA-G-derived nonamer. Eur J Immunol. 1998;28:2854-63.

37. Miller JD, Weber DA, Ibegbu C, Pohl J, Altman JD, Jensen PE. Analysis of HLA-E peptide-binding specificity and contact residues in bound peptide required for recognition by CD94/NKG2. J Immunol. 2003;171:1369-75.

38. Brooks AG, Borrego F, Posch PE, Patamawenu A, Scorzelli CJ, Ulbrecht M, Weiss EH, Coligan JE. Specific recognition of HLA-E, but not classical, HLA class I molecules by soluble CD94/NKG2A and NK cells. $J$ Immunol. 1999;162:305-13.

39. Lauterbach N, Voorter CE, Tilanus MG. Molecular typing of HLA-E. Methods Mol Biol 2012;882:143-58.

40. Cheent KS, Jamil KM, Cassidy S, Liu M, Mbiribindi B, Mulder A, Claas FH, Purbhoo MA, Khakoo SI. Synergistic inhibition of natural killer cells by the nonsignaling molecule CD94. Proc Natl Acad Sci U SA. 2013;110:16981-6.

41. Vales-Gomez M, Reyburn HT, Erskine RA, Lopez-Botet M, Strominger JL. Kinetics and peptide dependency of the binding of the inhibitory NK receptor CD94/NKG2-A and the activating receptor CD94/NKG2-C to HLA-E. Embo J. 1999;18:4250-60.

42. Borrego F, Kabat J, Sanni TB, Coligan JE. NK cell CD94/NKG2A inhibitory receptors are internalized and recycle independently of inhibitory signaling processes. J Immunol. 2002;169:6102-11.

43. Groh V, Wu J, Yee C, Spies T. Tumour-derived soluble MIC ligands impair expression of NKG2D and Tcell activation. Nature. 2002;419:734-8. 
44. Dietrich J, Hou X, Wegener AM, Pedersen LO, Odum N, Geisler C. Molecular characterization of the dileucine-based internalization motif of the T cell receptor. J Biol Chem. 1996;271:11441-8.

45. von Essen M, Menné C, Nielsen BL, Lauritsen JP, Dietrich J, Andersen PS, Karjalainen K, $\varnothing$ dum N, Geisler C. The CD3 gamma leucine-based receptor-sorting motif is required for efficient ligand-mediated TCR down-regulation. J Immunol. 2002;168:4519-23.

46. Tripathi P, Agrawal S. The role of human leukocyte antigen E and G in HIV infection. Aids. 2007;21: 1395-404.

47. Lozano JM, González R, Kindelán JM, Rouas-Freiss N, Caballos R, Dausset J, Carosella ED, Peña J. Monocytes and T lymphocytes in HIV-1-positive patients express HLA-G molecule. Aids. 2002;16: 347-51.

48. Onno M, Pangault C, Le Friec G, Guilloux V, André P, Fauchet R. Modulation of HLA-G antigens expression by human cytomegalovirus: specific induction in activated macrophages harboring human cytomegalovirus infection. J Immunol. 2000;164:6426-34.

49. Yan WH, Lin A, Chen BG, Chen SY. Induction of both membrane-bound and soluble HLA-G expression in active human cytomegalovirus infection. J Infect Dis. 2009;200:820-6.

50. Foley B, Cooley S, Verneris MR, Pitt M, Curtsinger J, Luo X, Lopez-Vergès S, Lanier LL, Weisdorf D, Miller JS. Cytomegalovirus reactivation after allogeneic transplantation promotes a lasting increase in educated NKG2C+ natural killer cells with potent function. Blood. 2012;119:2665-74.

51. Siewiera J, El Costa H, Tabiasco J, Berrebi A, Cartron G, Le Bouteiller P, Jabrane-Ferrat N. Human cytomegalovirus infection elicits new decidual natural killer cell effector functions. PLoS Pathog. 2013; 9:e1003257.

52. Lampen MH, Hassan C, Sluijter M, Geluk A, Dijkman K, Tjon JM, de Ru AH, van der Burg SH, van Veelen PA, van Hall T. Alternative peptide repertoire of HLA-E reveals a binding motif that is strikingly similar to HLA-A2. Mol Immunol. 2013;53:126-31. 


\section{Chapter 8}

HLA-E polymorphism is associated with risk of infection and severe acute GVHD in unrelated hematopoietic stem cell transplantation

Nina Lauterbach, Christina Voorter, Lisa Rybicki, Lotte Wieten, Mathijs Groeneweg, Ronald Sobecks, Matt Kalaycio, Marcel Tilanus, Medhat Askar 


\section{Abstract}

The current matching procedure for hematopoietic stem cell transplantation (HSCT) includes allele matching for HLA-A, -B, -C, -DRB1 and -DQB1. HLA-E is a non-classical HLA class I molecule that is known to modulate the immune response by presentation of self and non-self peptides to NK and T cells. HLA-E is the least polymorphic of all HLA class I loci with only two functional alleles, HLA-E*01:01 and HLA-E*01:03. We aimed to study HLA-E genotype and matching status of patients and donors following unrelated HSCT. We retrospectively studied the HLA-E genotype in 81 patients from a single center who underwent HSCT with an 10/10 HLA matched unrelated donor. Our study reveals that HLA-E mismatching in Graft-Versus-Host (GVH) direction is related with a poorer neutrophil engraftment $(\mathrm{HR}=0.32, p=<0.001)$, and is associated with a higher risk of grade 3-4 acute Graft-versus-Host Disease (GVHD) (HR=4.40, $p=0.03$ ) compared to HLA-E matching. Homozygosity for HLA-E*01:01 in the donor is associated with a higher risk of grade 3-4 acute GVHD compared to HLA-E*01:01,01:03 and HLA-E*01:03 (HR=5.40, $p=0.021$ ). Regarding infections, homozygosity for HLA-E*01:01 in the recipient is associated with a lower risk of any infections ( $\mathrm{HR}=0.50, p=0.028$ ) and non-CMV infections ( $\mathrm{HR}=0.53, p=0.046)$ compared to HLA-E*01:01,01:03 and HLA-E*01:03. Therefore, our results suggest a role of HLA-E polymorphism and matching in the development of post-transplantation complications in HSCT. 


\section{Introduction}

HLA matching between patient and donor in unrelated stem cell transplantation contributes to a better engraftment and an improved patient outcome regarding posttransplantation complications. Current matching procedures generally include allele matching for HLA-A, $-B,-C,-D R B 1$ and $-D Q B 1^{1}$. The human leukocyte antigen gene cluster includes the highly polymorphic classical HLA class I molecules HLA-A, -B and -C and the low polymorphic non-classical molecules HLA-E, $-F$ and $-G$. HLA-E is particularly interesting for its function in regulating NK cell immunity. HLA-E is ubiquitously expressed and modulates the immune response by presentation of HLA class I derived leader peptides to the NK cell via the inhibitory receptor NKG2A and the activating receptor $\mathrm{NKG}_{2} \mathrm{C}^{2-4}$. Various viruses are known to downregulate HLA class I molecules on the cell surface to evade $T$ cell immunity, nonetheless consequently HLA-E surface expression will be decreased, thereby releasing the NK cell from the NKG2A dependent inhibitory signal ${ }^{5}$. HLA-E functions as an indirect monitoring system for HLA class I cell surface expression to distinguish self- from non-self. In addition to the presentation of HLA class I leader peptides, HLA-E binds peptides derived from viruses, bacteria and the heat shock protein 60 . These peptides can be presented to the NK cell and/or to a subset of CD8+ T cells ${ }^{6-9}$. Studies have shown that HLA-E in combination with CMV derived UL40 peptide can trigger killing by CD8+TCR $\alpha \beta+T$ cells ${ }^{10}$ and CD8+ T cell proliferation was observed when targeted against HLA-E presenting the peptide from the mycobacterium tuberculosis ${ }^{8}$.

HLA-E is the least polymorphic of all HLA class I alleles with only thirteen alleles encoding five different proteins described in the human population. The alleles HLA-E*01:01 and HLA-E*01:03 differ by a single amino acid on the alpha2 domain of the HLA-E heavy chain; the allele HLA-E*01:01 encodes at position 107 an Arg were HLA-E*01:03 has a Gly. Both alleles have been detected in the population at high frequencies and have been proposed to be under some form of stabilizing selection ${ }^{11,12}$. This could imply that the alleles exhibit functional differences with respect to the immune response. We demonstrated that HLA-E is higher expressed on lymphocytes and monocytes from HLA-E*01:03 homozygous subjects compared to HLA-E*01:01 (Lauterbach et al. submitted). In addition, we and others showed that HLA-E expression and the peptide presented by HLA-E modulate the NK cell function. In various cancers, e.g. cervical, breast, glioblastoma, ovarian and colorectal $^{13-18}, \mathrm{HLA}-\mathrm{E}$ expression is associated with tumor progression and patient survival. In the setting of stem cell transplantation, HLA-E genotype has been associated with patient outcome, as HLA-E*01:03 genotype in patient and donor is indicated to confer protection against graft-versus-host disease (GVHD) and is associated with better survival ${ }^{19-21}$.

The aim of this study was to explore the effects of HLA-E polymorphism on patient outcome in unrelated hematopoietic stem cell transplantation (HSCT). We retrospectively studied HLA-E genotype in 81 patients who underwent HSCT with an 10/10 
HLA matched unrelated donor and analyzed the effect of HLA-E patient and donor genotype and mismatching on patient outcome.

\section{Patient and Methods}

\subsection{Study population}

The study included 81 patients admitted to the Cleveland Clinic who received HSCT from an unrelated donor between August 2003 and December 2010. Written informed consent was obtained from all patients and donors as required by the Institutional Review Board in accordance with the Declaration of Helsinki. All transplants were allelematched for HLA-A, -B, -C, -DRB1, and -DQB1, determined by sequence-based typing (SBT). Patient characteristics and the potential risk factors for allogeneic HSCT are listed in Table 8.1.

Table 8.1 Descriptive information.

\begin{tabular}{|c|c|c|c|c|c|}
\hline Variable & $\mathrm{N}$ & $\%$ & Variable & $\mathrm{N}$ & $\%$ \\
\hline Gender & & & \multicolumn{3}{|c|}{ Transplant type and source of hematopoietic cells } \\
\hline Male & 47 & 58.0 & Myeloablative allo - BM & 48 & 59.3 \\
\hline Female & 34 & 42.0 & Myeloablative allo - PSC & 9 & 11.1 \\
\hline Race & & & Mini allo - PSC & 24 & 29.6 \\
\hline Caucasian & 80 & 98.8 & Conditioning regimen & & \\
\hline American Indian & 1 & 1.2 & $\mathrm{Bu} / \mathrm{Cy}$ & 34 & 42.0 \\
\hline Age at transplant, years & & & $\mathrm{Bu} / \mathrm{CY} / \mathrm{VP}$ & 5 & 6.2 \\
\hline mean \pm SD & \multicolumn{2}{|l|}{$45 \pm 14$} & Flu/VP & 22 & 27.2 \\
\hline median (range) & \multicolumn{2}{|l|}{$47(17-70)$} & TBI/VP & 14 & 17.3 \\
\hline Comorbidity index (HCT-Cl) & & & Cy/TBI/ATG & 2 & 2.5 \\
\hline Low-risk & 27 & 33.3 & $\mathrm{ECP} / \mathrm{Cy} / \mathrm{TBI}$ & 2 & 2.5 \\
\hline Intermediate-risk & 29 & 35.8 & Fly/CTX & 2 & 2.5 \\
\hline High-risk & 25 & 30.9 & \multicolumn{3}{|l|}{ Donor age, years $(n=78$} \\
\hline Diagnosis & & & mean $\pm S D$ & \multicolumn{2}{|c|}{$33 \pm 10$} \\
\hline AML & 29 & 35.8 & median (range) & \multicolumn{2}{|c|}{$31(19-59)$} \\
\hline MDS & 21 & 25.9 & Donor gender $(n=80)$ & & \\
\hline ALL & 12 & 14.8 & Male & 55 & 68.8 \\
\hline $\mathrm{NHL}$ & 9 & 11.1 & Female & 25 & 31.3 \\
\hline CML & 2 & 2.5 & \multicolumn{3}{|c|}{ Donor to recipient gender $(n=80)$} \\
\hline $\mathrm{HL}$ & 2 & 2.5 & $\mathrm{~F}$ to $\mathrm{F}$ & 11 & 13.8 \\
\hline Other* & 6 & 7.4 & $\mathrm{~F}$ to $\mathrm{M}$ & 14 & 17.5 \\
\hline Diagnosis type & & & \multicolumn{3}{|l|}{ Donor baseline CMV } \\
\hline Myeloid & 55 & 67.9 & Positive & 18 & 22.5 \\
\hline Lymphoid & 24 & 29.6 & Negative & 62 & 77.5 \\
\hline Other & 2 & 2.5 & \multicolumn{3}{|l|}{ Recipient baseline CMV } \\
\hline Disease status at transplan & & & Positive & 51 & 63.0 \\
\hline $\mathrm{CR}$ & 35 & 43.2 & Negative & 30 & 37.0 \\
\hline$<\mathrm{CR}$ & 46 & 56.8 & & & \\
\hline
\end{tabular}

* 1 each biohenotypic acute leukemia, myelofibrosis, CLL, myeloproliferative disorder, myeloid sarcoma, PNH 


\subsection{HLA-E genotyping}

HLA-E genotyping for the HLA-E*01:01 and HLA-E*01:03 alleles in patients and donors, was performed using PCR-SSO luminex method as earlier described ${ }^{22}$.

\subsection{Statistical analysis}

Fourteen outcomes were assessed: neutrophil engraftment (days to ANC $>500$ ), platelet engraftment (days to platelets $>20,000$ ), any acute GvHD, grade 2-4 acute GvHD, grade 3-4 acute GvHD, any chronic GvHD, extensive chronic GvHD, relapse, relapse mortality, nonrelapse mortality, all-cause mortality, any infection, CMV infections and non-CMV infections. Outcomes were estimated using Kaplan-Meier method and significances were estimated by the log-rank test. Multivariate analysis was performed using the Cox proportional hazard model. Testing the significance of particular regression coefficients was performed by Wald statistics. Multivariable prognostic factors (gender, age at transplant, comorbidity index, diagnosis, disease state, type of transplant, CMV status, HLA-E mismatch) for each outcome were assessed using stepwise Cox proportional hazards with a variable entry criterion of $p<0.10$ and a variable retention criterion of $P<0.05$. Acute GVHD was diagnosed and assessed according to standard criteria ${ }^{23}$. Severe acute GVHD, including grades I-IV, was regarded for analysis. The chi-square test was used for $2 \times 2$ table analysis, and standard $t$ test was performed for continuous variables. All designated $p$ values are from two-sided tests and values less than 0.05 were considered significant. All analyses were performed using Statistica version 7. Univariable Cox results regarding the effect of patient HLA-E genotype, donor HLA-E genotype and HLA-E matching status are summarized in Tables 8.2 and 8.3 as the hazard ratio $(\mathrm{HR}), 95 \%$ confidence interval for the $\mathrm{HR}(95 \% \mathrm{Cl})$, and corresponding $p$ value. In one donor, HLA-E genotype could not be determined. Therefore to assess the effect of HLA-E mismatching, 80 patient-donor pairs were studied and when analyzing the clinical effect of donor HLA-E genotype 80 donors were studied.

\section{Results}

\subsection{Frequency of HLA-E genotypes}

HLA-E allele frequencies in this study were as follows: From the patients, $27.2 \%$ had HLA-E*01:01,01:01, 24.7\% had HLA-E*01:03,01:03 and 48.2\% had HLA-E*01:01,01:03 genotype. In the donor pool similar frequencies were observed, as $26.6 \%$ had HLA-E*01:01,01:01, 23.8\% had HLA-E*01:03,01:03 and 50\% had HLA-E*01:01,01:03 genotype. Regarding HLA-E mismatched transplants, $22.5 \%$ showed a mismatch in graft-versus-host (GVH) direction and $23.8 \%$ showed a mismatch in host-versus-graft (HVG) direction. 
Table 8.2 Statistical analyses regarding the effect of HLA-E genotype in patients and donors on the occurrence of patient outcome variables.

\begin{tabular}{lcc}
\hline Outcome variables & $\begin{array}{c}\text { Donor HLA-E*01:01,01:01 vs HLA- } \\
\text { E*01:01,01:03 or HLA-E*01:03,01:03 } \\
\text { HR / 95\% Cl / P value }\end{array}$ & $\begin{array}{c}\text { Recipient HLA-E*01:01,01:01 vs HLA- } \\
E^{*} 01: 01,01: 03 \text { or HLA-E*01:03,01:03 } \\
\text { HR / 95\% Cl / P value }\end{array}$ \\
\hline Neutrophil engraftment & $0.90 / 0.52-1.57 / 0.71$ & $1.63 / 0.93-2.85 / 0.09$ \\
Platelet engraftment & $0.93 / 0.51-1.65 / 0.81$ & $0.88 / 0.84-1.62 / 0.68$ \\
Any acute GVHD & $1.54 / 0.80-2.93 / 0.19$ & $1.18 / 0.64-2.17 / 0.61$ \\
Grade 2-4 acute GVHD & $1.32 / 0.62-2.79 / 0.47$ & $1.04 / 0.50-2.18 / 0.91$ \\
Grade 3-4 acute GVHD & $\mathbf{5 . 4 0 / 1 . 2 9 - 2 2 . 6 / 0 . 0 2 1}$ & $0.78 / 0.15-4.10 / 0.77$ \\
Any chronic GVHD & $0.71 / 0.29-1.74 / 0.45$ & $0.79 / 0.34-1.86 / 0.59$ \\
Extensive chronic GHVD & $1.06 / 0.34-3.25 / 0.93$ & $0.60 / 0.9-1.93 / 0.39$ \\
Relapse & $0.79 / 0.30-2.06 / 0.63$ & $0.72 / 0.28-1.85 / 0.49$ \\
Relapse mortality & $1.16 / 0.41-3.27 / 0.78$ & $1.09 / 0.36-3.33 / 0.88$ \\
Non-relapse mortality & $0.58 / 0.21-1.61 / 0.30$ & $0.44 / 0.17-1.19 / 0.11$ \\
All cause mortality & $0.80 / 0.39-1.64 / 0.54$ & $0.63 / 0.31-1.31 / 0.22$ \\
Any infection & $0.78 / 0.44-1.37 / 0.39$ & $\mathbf{0 . 5 0} / \mathbf{0 . 2 7}-\mathbf{0 . 9 3 ~ / 0 . 0 2 8}$ \\
CMV infection & $1.32 / 0.58-3.05 / 0.51$ & $0.86 / 0.34-2.14 / 0.74$ \\
Non-CMV & $0.91 / 0.51-1.60 / 0.74$ & $\mathbf{0 . 5 3 ~ / 0 . 2 9 - 0 . 9 9 ~ / ~ 0 . 0 4 6 ~}$
\end{tabular}

Numbers in bold represent significant differences between the HLA-E genotypes for the specific outcome variable.

Table 8.3 Statistical analyses regarding the effect of an HLA-E mismatch in GVH and HVG direction on the occurrence of patient outcome variables.

\begin{tabular}{lcc}
\hline Outcome variables & $\begin{array}{c}\text { HLA-E mismatch GVH direction } \\
\text { yes vs no } \\
\mathrm{HR} / \mathbf{9 5 \%} \mathrm{Cl} / \mathrm{p} \text {-value }\end{array}$ & $\begin{array}{c}\text { HLA-E mismatch HVG direction } \\
\text { yes vs no }\end{array}$ \\
\hline Neutrophil engraftment & $\mathbf{0 . 3 2 / 0 . 1 7 - 0 . 6 1 / < 0 . 0 0 1}$ & $\mathbf{H} \% \mathrm{Cl} / p$-value \\
Platelet engraftment & $0.69 / 0.37-1.30 / 0.26$ & $0.79 / 0.46-1.34 / 0.38$ \\
Any acute GVHD & $1.37 / 0.74-2.52 / 0.31$ & $0.76 / 0.42-1.37 / 0.36$ \\
Grade 2-4 acute GVHD & $1.01 / 0.47-2.13 / 0.99$ & $0.58 / 0.29-1.15 / 0.12$ \\
Grade 3-4 acute GVHD & $\mathbf{4 . 4 0 / 1 . 1 5 - 1 6 . 8 / 0 . 0 3}$ & $0.70 / 0.31-1.60 / 0.40$ \\
Any chronic GVHD & $0.76 / 0.31-1.84 / 0.54$ & $1.08 / 0.22-5.35 / 0.92$ \\
Extensive chronic GHVD & $1.10 / 0.40-3.01 / 0.86$ & $0.70 / 0.29-1.70 / 0.43$ \\
Relapse & $1.09 / 0.46-2.58 / 0.85$ & $0.54 / 0.16-1.82 / 0.32$ \\
Relapse mortality & $0.96 / 0.23-2.93 / 0.95$ & $1.19 / 0.50-2.82 / 0.69$ \\
Non-relapse mortality & $1.43 / 0.66-3.12 / 0.37$ & $1.71 / 0.64-4.55 / 0.29$ \\
All cause mortality & $1.25 / 0.66-2.35 / 0.50$ & $0.51 / 0.18-1.46 / 0.21$ \\
\hline
\end{tabular}

Numbers in bold represent significant differences between the HLA-E genotypes for the specific outcome variable.

\subsection{Neutrophil engraftment}

Results demonstrated that 18 patients who received a transplant from an HLA-E mismatched donor (in GVH direction) were associated with a lower occurrence of neutrophil engraftment than 62 patients receiving a transplant from an HLA-E matched donor $(\mathrm{HR}=0.32,95 \% \mathrm{Cl}=0.17-0.61, p=<0.001$, Figure $8.1 \mathrm{~A})$, this was confirmed in 
multivariate analysis ( $\mathrm{HR}=0.28,95 \% \mathrm{Cl}=0.14-0.55, p=<0.001$ ). HLA-E mismatching in HVG direction was not associated with neutrophil engraftment $(\mathrm{HR}=0.79,95 \% \mathrm{Cl}=0.46$ 1.34, $p=0.38$, Figure 8.1B). HLA-E alleles of patient and donor in itself was not associated with neutrophil engraftment.

A

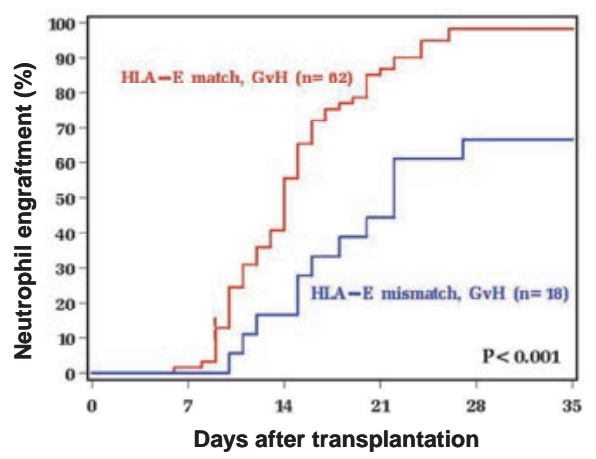

B

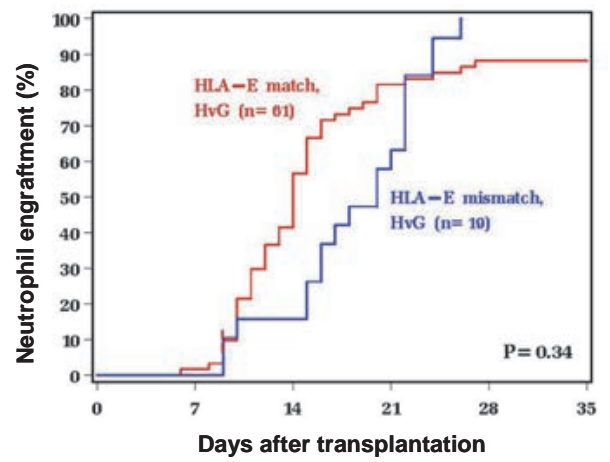

Figure 8.1 HLA-E mismatching in GVH direction is associated with a lower chance of neutrophil engraftment compared to HLA-E matching. A-B) Shown is the percentage of patients experiencing neutrophil engraftment 0-35 days after receiving a stem cell transplant from an unrelated donor. In A) Blue line represents 10/10 HLA matched patients with an HLA-E mismatch in GVH direction and red line represents 10/10 HLA matched patients with an HLA-E match in GVH direction. In B) Blue line represents 10/10 HLA matched patients with an HLA-E mismatch in HVG direction and red line represents 10/10 HLA matched patients with an HLA-E match in HVG direction.

\subsection{Graft-Versus-Host Disease}

Sixteen of 81 (19.8\%) patients developed grade I acute GVHD, 29 of 81 (35.8\%) patients developed grade II acute GVHD and 10 of 81 (12.4\%) developed grade III/IV acute GVHD (severe acute GVHD). Twenty-one of 81 patients developed extensive chronic GVHD. Of the 50 patients who died, four (0.8\%) died due to acute GVHD and four $(0.8 \%)$ died due to chronic GVHD. With respect to the HLA-E mismatching status, an HLA-E mismatch (in GVH direction) was significantly associated with a higher risk of severe acute GVHD compared to an HLA-E match ( $\mathrm{HR}=4.40, \mathrm{Cl}=1.15-16.8, p=0.03$, Figure 8.2A). In the donor, homozygosity for HLA-E*01:01 was associated with a higher risk of severe acute GVHD when compared to HLA-E*01:01,01:03 and HLA-E*01:03 (HR=5.40, Cl=1.29-22.6, $p=0.021$, Figure 8.2B). 
A

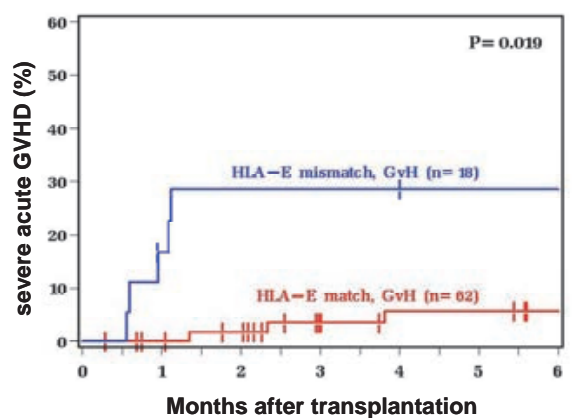

B

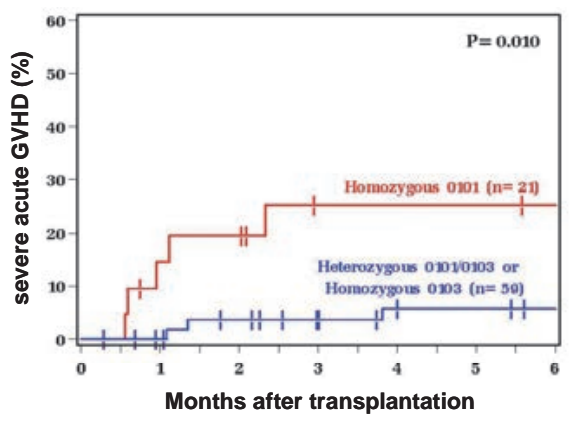

Figure 8.2 An HLA-E mismatch in GVH direction is associated with a higher risk of severe acute GVHD and the presence of HLA-E*01:03 is associated with a lower risk of severe acute GVHD. A-B) Shown is the percentage of patients experiencing severe acute GVHD 0-6 months after receiving a stem cell transplant from an unrelated donor. In A) Blue line represents 10/10 HLA matched patients experiencing severe acute GVHD who received an HLA-E mismatched transplant and red line represents 10/10 HLA matched patients experiencing severe acute GVHD who received an HLA-E matched transplant. In B) Blue line represents patients experiencing severe acute GVHD after receiving a transplant from an HLA-E heterozygous or HLA-E*01:03 homozygous donor and red line represents patients experiencing severe acute GVHD after receiving a transplant from an HLA-E*01:01 homozygous donor.

\subsection{Infections}

Twenty-six (32\%) patients experienced CMV infections, 63 (78\%) patients experienced non-CMV infections, and 64 (79\%) patients had any infection. Of the 50 patients who died, seven (14\%) died due to infections. In the recipient, homozygosity for HLA$E^{*} 01: 01$ was associated with a significant lower risk of any infections when compared to HLA-E*01:01,01:03 and HLA-E*01:03 (HR=0.50, $\mathrm{Cl}=0.27-0.93, p=0.028$, Figure 8.3A).

A

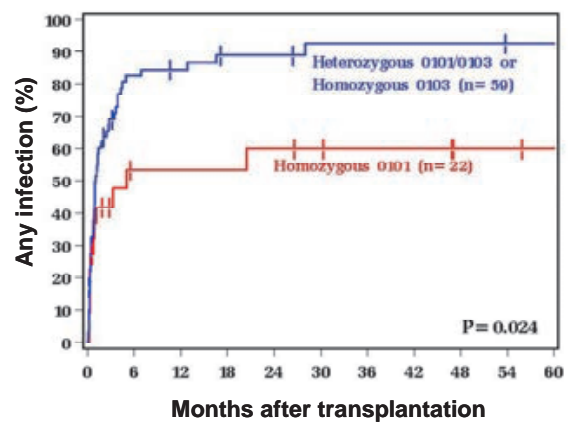

B

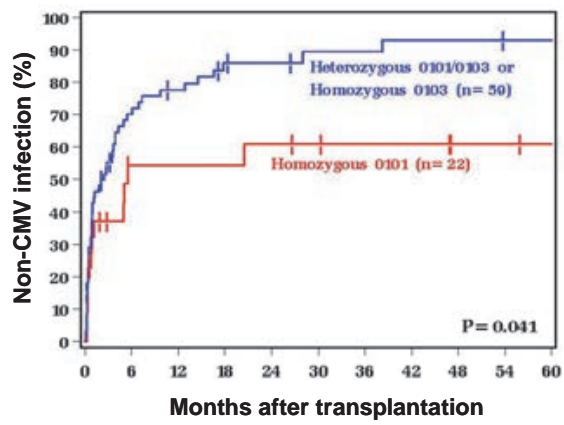

Figure 8.3 Homozygosity for HLA-E*01:01 in the recipient is associated with a lower risk of infections after unrelated HSCT. A) Shown is the percentage of patients experiencing any infections and B) the percentage of patients experiencing non-CMV infections 0-60 months after receiving a stem cell transplant from an unrelated donor. A-B) The blue lines represent recipients who are HLA-E heterozygous or HLA-E*01:03 homozygous and the red lines represent recipients who are HLA$E^{*}$ 01:01 homozygous. 
Moreover, homozygosity for HLA-E*01:01 in the patient showed a significant lower incidence of non-CMV infection when compared to HLA-E*01:01,01:03 and HLA-E*01:03 ( $\mathrm{HR}=0.53, \mathrm{Cl}=0.29-0.99, p=0.046$, Figure 8.3B). This suggests, that the presence of HLA-E*01:03 increases the risk of infections post-transplantation.

\section{Discussion}

In this study we explored the effect of HLA-E polymorphism on the occurrence of posttransplantation complications in a cohort of 81 patients who received a transplant from an unrelated donor. Our results imply that the presence of HLA-E*01:03 is associated with a lower risk of severe acute GVHD. Previously, HLA-E genotype has been associated with the incidence of GVHD and mortality following $\mathrm{HSCT}^{19-21,24}$. We showed that HLA-E surface expression level is higher on lymphocytes and monocytes from HLA-E*01:03 homozygous individuals when compared to HLA-E*01:01 homozygous individuals (Lauterbach et al. submitted). This is in line with observations in cell lines transfected with a vector containing either the coding region of HLA-E*01:01 or HLA-E*01:03 ${ }^{25,26}$. Moreover, we demonstrated that HLA-E expression is essential in the regulation of NK cell function (Lauterbach et al. submitted), and other groups described HLA-E as a ligand to various $T$ cell subsets ${ }^{27-30}$. Together, these results could be explanatory for the observed effects of HLA-E genotype on acute GVHD, as it can be suggested that cells expressing HLA-E*01:03 confer a better protection against NK cell killing following HSCT.

Interestingly, the presence of HLA-E*01:03 seems to exhibit a deleterious effect on the occurrence of any infection and non-CMV infection. Since we previously showed that HLA-E is higher expressed in HLA-E*01:03 than HLA-E*01:01, it could be speculated that infected cells that express HLA-E*01:03 inhibit the NK cell more effectively than infected cells that express HLA-E*01:01. Unfortunately, due to a limited patient cohort we could only study the occurrence of any infection, non-CMV infections and CMV infections. We could not study the effect of HLA-E on the various types of infection including viral, bacterial and fungal. In the study of Tamouza et al. $^{31}$, the presence of HLA-E*01:03 was associated with a lower risk of severe bacterial infection. However, this association was based on the HLA-E genotype in the donor, not the recipient as in the current study. Moreover, almost all patients who experienced severe bacterial infection, experienced sepsis, which could represent other immunological mechanisms. A role for HLA-E polymorphism in allorecognition could be assumed as our data indicates that an HLA-E mismatch in GVH direction is associated with a higher risk of severe acute GVHD. Furthermore, HLA-E mismatching was associated with a poorer neutrophil engraftment compared to HLA-E matching. This effect was only visible with an HLA-E mismatch in the GVH direction, not in HVG direction. Matsuno et al. ${ }^{32}$ also described that HLA disparity in GVH direction affected engraftment kinetics more than mismatches in HVG direction. They state that HLA disparity in the GVH direction can 
trigger alloimmune reactions, which evoke hypercytokinemia and macrophage activation and occasionally result in establishment of hemophagocytic syndrome, thereby leading to graft failure in recipients.

HLA-E polymorphism seem to play a dual role in stem cell transplantation as the presence of $\mathrm{HLA}-\mathrm{E}^{*} 01: 03$ has a deleterious effect on the occurrence of infections, whereas the presence of HLA-E*01:03 was associated with a lower risk of severe acute GVHD. Moreover, HLA-E mismatching was associated with a higher risk of severe acute GVHD and poorer neutrophil engraftment than HLA-E matching. Although this cohort included 81 patient-donor pairs and these findings need to be confirmed in a larger patient-donor cohort, our study implies a role for HLA-E polymorphism and matching in the development of post-transplantation complications following unrelated HSCT.

\section{Acknowledgements}

We thank Jar-How Lee (One Lambda) for providing the HLA-E SSO luminex beads 


\section{References}

1. Tiercy JM. Unrelated hematopoietic stem cell donor matching probability and search algorithm. Bone Marrow Re.s 2012: 2012: 695018.

2. Lee $N$, Llano M, Carretero M, Ishitani A, Navarro F, López-Botet M, Geraghty DE. HLA-E is a major ligand for the natural killer inhibitory receptor CD94/NKG2A. Proc Natl Acad Sci U S A. 1998: 95: 5199-204.

3. Wei XH, Orr HT. Differential expression of HLA-E, HLA-F, and HLA-G transcripts in human tissue. Hum Immunol. 1990: 29: 131-42.

4. Coupel S, Moreau A, Hamidou M, Horejsi V, Soulillou JP, Charreau B. Expression and release of soluble HLA-E is an immunoregulatory feature of endothelial cell activation. Blood. 2007: 109: 2806-14.

5. Lodoen MB, Lanier LL. Viral modulation of NK cell immunity. Nat Rev Microbiol 2005: 3: 59-69.

6. Ulbrecht M, Martinozzi S, Grzeschik M, Hengel H, Ellwart JW, Pla M, Weiss EH. Cutting edge: the human cytomegalovirus UL40 gene product contains a ligand for HLA-E and prevents NK cell-mediated lysis. J Immunol. 2000: 164: 5019-22.

7. Pietra G, Romagnani C, Mazzarino P, Falco M, Millo E, Moretta A, Moretta L, Mingari MC. HLA-Erestricted recognition of cytomegalovirus-derived peptides by human CD8+ cytolytic T lymphocytes. Proc Natl Acad Sci U S A. 2003: 100: 10896-901.

8. Joosten SA, van Meijgaarden KE, van Weeren PC, Kazi F, Geluk A, Savage ND, Drijfhout JW, Flower DR, Hanekom WA, Klein MR, Ottenhoff TH. Mycobacterium tuberculosis peptides presented by HLA-E molecules are targets for human CD8 T-cells with cytotoxic as well as regulatory activity. PLoS Pathog. 2010: 6: e1000782.

9. Michaelsson J, Teixeira de Matos C, Achour A, Lanier LL, Karre K, Soderstrom K. A signal peptide derived from hsp60 binds HLA-E and interferes with CD94/NKG2A recognition. J Exp Med. 2002: 196: 1403-14.

10. Romagnani C, Pietra G, Falco M, Mazzarino P, Moretta L, Mingari MC. HLA-E-restricted recognition of human cytomegalovirus by a subset of cytolytic T lymphocytes. Hum Immunol. 2004: 65: 437-45.

11. Geraghty DE, Stockschleader M, Ishitani A, Hansen JA. Polymorphism at the HLA-E locus predates most HLA-A and -B polymorphism. Hum Immunol. 1992: 33: 174-84.

12. Grimsley C, Ober C. Population genetic studies of HLA-E: evidence for selection. Hum Immunol 1997: 52: 33-40.

13. Gonçalves MA, Le Discorde M, Simões RT, Rabreau M, Soares EG, Donadi EA, Carosella ED. Classical and non-classical HLA molecules and p16(INK4a) expression in precursors lesions and invasive cervical cancer. Eur J Obstet Gynecol Reprod Biol. 2008: 141: 70-4.

14. de Kruijf EM, Sajet A, van Nes JG, Natanov R, Putter H, Smit VT, Liefers GJ, van den Elsen PJ, van de Velde CJ, Kuppen PJ. HLA-E and HLA-G expression in classical HLA class I-negative tumors is of prognostic value for clinical outcome of early breast cancer patients. J Immunol. 2010: 185: 7452-9.

15. Kren L, Slaby O, Muckova K, Lzicarova E, Sova M, Vybihal V, Svoboda T, Fadrus P, Lakomy R, Vanhara P, Krenova Z, Sterba J, Smrcka M, Michalek J. Expression of immune-modulatory molecules HLA-G and HLA-E by tumor cells in glioblastomas: an unexpected prognostic significance? Neuropathology. 2011: 31: 129-34.

16. Gooden M, Lampen M, Jordanova ES, Leffers N, Trimbos JB, van der Burg SH, Nijman H, van Hall T. HLAE expression by gynecological cancers restrains tumor-infiltrating CD8 T lymphocytes. Proc Natl Acad Sci US A. 2011: 108: 10656-61.

17. Benevolo M, Mottolese M, Tremante E, Rollo F, Diodoro MG, Ercolani C, Sperduti I, Lo Monaco E, Cosimelli M, Giacomini P. High expression of HLA-E in colorectal carcinoma is associated with a favorable prognosis. J Transl Med. 2011: 9: 184.

18. Bossard C, Bézieau S, Matysiak-Budnik T, Volteau C, Laboisse CL, Jotereau F, Mosnier JF. HLA-E/beta2 microglobulin over-expression in colorectal cancer is associated with recruitment of inhibitory immune cells and tumor progression. Int J Cancer. 2012;131:855-63.

19. Tamouza R, Busson M, Rocha V, Fortier C, Haddad Y, Brun M, Boukouaci W, Bleux H, Socié G, Krishnamoorthy R, Toubert A, Gluckman E, Charron D. Homozygous status for HLA-E*0103 confers protection from acute graft-versus-host disease and transplant-related mortality in HLA-matched sibling hematopoietic stem cell transplantation. Transplantation. 2006: 82: 1436-40. 
20. Ludajic K, Rosenmayr A, Faé I, Fischer GF, Balavarca Y, Bickeböller H, Kalhs P, Greinix HT. Association of HLA-E polymorphism with the outcome of hematopoietic stem-cell transplantation with unrelated donors. Transplantation. 2009: 88: 1227-8.

21. Danzer M, Polin H, Pröll J, Haunschmid R, Hofer K, Stabentheiner S, Hackl C, Kasparu H, König J, Hauser $H$, Binder M, Weiss R, Gabriel C, Krieger O. Clinical significance of HLA-E*0103 homozygosity on survival after allogeneic hematopoietic stem-cell transplantation. Transplantation. 2009: 88: 528-32.

22. Lauterbach N, Voorter CE, Tilanus MG. Chapter 8: Molecular Typing of HLA-E. In: ed. Methods in Molecular Biology, Immunogenetics: Methods and Applications in Clinical Practice. Springer, 2012: 14358.

23. Przepiorka D, Weisdorf D, Martin P, Klingemann HG, Beatty P, Hows J, Thomas ED. 1994 Consensus Conference on Acute GVHD Grading. Bone Marrow Transplant. 1995: 15: 825-8.

24. Hosseini E, Schwarer AP, Ghasemzadeh M. The impact of HLA-E polymorphisms in graft-versus-host disease following HLA-E matched allogeneic hematopoietic stem cell transplantation. Iran J Allergy Asthma Immunol. 2012: 11: 15-21.

25. Strong RK, Holmes MA, Li P, Braun L, Lee N, Geraghty DE. HLA-E allelic variants. Correlating differential expression, peptide affinities, crystal structures, and thermal stabilities. J Biol Chem. 2003: 278: 5082-90.

26. Maier S, Grzeschik M, Weiss EH, Ulbrecht M. Implications of HLA-E allele expression and different HLA-E ligand diversity for the regulation of NK cells. Hum Immunol. 2000: 61: 1059-65.

27. Heinzel AS, Grotzke JE, Lines RA, Lewinsohn DA, McNabb AL, Streblow DN, Braud VM, Grieser HJ, Belisle JT, Lewinsohn DM. HLA-E-dependent presentation of Mtb-derived antigen to human CD8+ T cells. J Exp Med. 2002: 196: 1473-81.

28. Gumá M, Busch LK, Salazar-Fontana LI, Bellosillo B, Morte C, García P, López-Botet M. The CD94/NKG2C killer lectin-like receptor constitutes an alternative activation pathway for a subset of CD8+ T cells. Eur J Immunol. 2005: 35: 2071-80.

29. Mazzarino P, Pietra G, Vacca P, Falco M, Colau D, Coulie P, Moretta L, Mingari MC. Identification of effector-memory CMV-specific T lymphocytes that kill CMV-infected target cells in an HLA-E-restricted fashion. Eur J Immunol. 2005: 35: 3240-7.

30. Muñoz-Cobo B, Solano C, Benet I, Costa E, Remigia MJ, de la Cámara R, Nieto J, López J, Amat P, GarciaNoblejas A, Bravo D, Clari MÁ, Navarro D. Functional profile of cytomegalovirus (CMV)-specific CD8(+) T cells and kinetics of NKG2C(+) NK Cells associated with the resolution of CMV DNAemia in allogeneic stem cell transplant recipients. J Med Virol. 2012: 84: 259-67.

31. Tamouza R, Rocha V, Busson M, Fortier C, El Sherbini SM, Esperou H, Filion A, Socié G, Dulphy N, Krishnamoorthy R, Toubert A, Gluckman E, Charron D. Association of HLA-E polymorphism with severe bacterial infection and early transplant-related mortality in matched unrelated bone marrow transplantation. Transplantation. 2005: 80: 140-4.

32. Matsuno N, Wake A, Uchida N, Ishiwata K, Araoka H, Takagi S, Tsuji M, Yamamoto H, Kato D, Matsuhashi Y, Seo S, Masuoka K, Miyakoshi S, Makino S, Yoneyama A, Kanda Y, Taniguchi S. Impact of HLA disparity in the graft-versus-host direction on engraftment in adult patients receiving reducedintensity cord blood transplantation. Blood. 2009: 114: 1689-95. 


\section{Chapter 9}

General discussion 
156 Chapter 9 


\section{Discussion part I}

\section{Defining HLA-DP immunogenicity}

HLA high-resolution matching between patient and donor in HSCT has contributed to an improved survival in transplant patients. ${ }^{1}$. An HLA-DP mismatch can elicit $\mathrm{T}$ cell alloreactivity $^{2}$, however the influence of HLA-DP mismatching on patient outcome is controversial. In case of an HLA-DPB1 allele mismatch in HLA-A,-B,-C,-DRB1 and -DQB1 matched unrelated $\mathrm{HSCT}$, several studies have shown an increase in the risk of GVHD ${ }^{3-8}$ and/or a decrease in disease relapse ${ }^{5,8-10}$. Other studies have indicated that disparity for HLA-DPB1 decreases survival rate, without having an effect on GVHD ${ }^{11}$. Flomenberg et al. ${ }^{12}$ found no effect of HLA-DPB1 matching status on either transplantation related complications or on disease relapse. The nomenclature of HLA-DP alleles is based on the order of allele identification, rather than on a serological antigen or cellular specificity as is the case with the other HLA loci. Consequently, an HLA-DP allele mismatch does not represent a functional mismatch, which could explain the contradictious results between various patient studies.

Evidence is accumulating describing that specific amino acid positions in the peptide binding groove of the beta chain are associated with $T$ cell alloreactivity ${ }^{13-17}$, and that certain mismatch combinations or amino acid residues are associated with better or worse patient outcome in $\mathrm{HSCT}^{10,18-20}$. This emphasizes the need to identify the functional epitopes in the HLA-DP molecule. Many studies use DP specific T cell clones to examine which amino acid positions play a role in $\mathrm{T}$ cell alloreactivity. The structural basis directing $\mathrm{T}$ cell allorecognition cannot be explained by polymorphic amino acid residues in the $\beta 1$-domain of the beta chain since reactivity with a specific residue was variable between different clones ${ }^{17,21}$. The algorithm proposed by Fleischhauer and colleagues was a breakthrough in resolving HLA-DP allorecognition as it illustrates that HLA-DPB1 alleles within one defined allele group can be considered permissive ${ }^{21}$. The usability of the algorithm was supported by various patient studies ${ }^{20-22}$, describing improved patient outcome with permissive HLA-DPB1 mismatches compared to nonpermissive mismatches. However, not all clinical studies could confirm the effect of the permissive DPB1 allele groups ${ }^{23}$. In contrast to the proposed algorithm which suggested that permissive mismatches result in low $\mathrm{T}$ cell responses, others revealed that polyclonal HLA-DP specific immune responses could be stimulated both against permissive and non-permissive mismatches. In addition, $\mathrm{T}$ cell clones specific for HLA-DP could be isolated from skin grafts with both permissive and non-permissive mismatches between patient and donor ${ }^{24-27}$. These findings demonstrate that the molecular mechanism directing permissive and non-permissive HLA-DP alloreactivity needs further investigation. 


\section{Functional implication of polymorphism outside the $\beta 1$-domain}

Polymorphism in the 32 -domain of the HLA class II molecule affects the CD4 coreceptor binding affinity ${ }^{28,29}$. We defined DPB1 polymorphism in the region encompassing exon 2 (chapter 2) and examined the functional consequences of these polymorphic positions (chapter 3 and 4). Our findings revealed that polymorphic residues encoded by exons 3 and 4 , have a limited impact on $\mathrm{T}$ cell allorecognition (chapter 3 and 4). We could not determine the functional impact of one of the identified polymorphic positions in exon 3 and in exon 4. Nevertheless, the single polymorphism in exon 3 was present in only one allele and the single substitution in exon 4 was present in only two less-frequent alleles. Concordant with our results, one other study showed that exon 3 polymorphism in the $\beta 2$-domain of HLA-DRB1 does not affect patient outcome in $\mathrm{HSCT}^{30}$. As an explanation for the observation that the polymorphic positions in exon 3 do not alter $\mathrm{T}$ cell allorecognition it can be suggested that the polymorphisms are located outside the CD4 co-receptor binding site ${ }^{31}$. On the other hand, these polymorphic positions could have other effects than influencing direct $T$ cell allorecognition. HLA class I polymorphism in the $\alpha 3$-domain and transmembrane region can influence $T$ cell alloreactivity via indirect recognition ${ }^{32}$, which cannot be ruled out for HLA-DP. Furthermore, mutations in the CD4 binding site of the 32 -domain of HLA class II impairs selection of CD4+ T cells in the thymus of mice $^{33}$. Regardless of the impaired selection, the eventually successfully selected CD4+ T cell subset responds equally well when stimulated with wild type or mutant HLA class II molecules ${ }^{34}$, which is in line with our results. It seems that the CD4 co-receptor is relevant for stabilization of the TCR recognition complex, but plays a limited role in the activation status of the T cell. However, mutations in the CD4 binding domain impair cytokine secretion $^{35}$. Thus, instead of analyzing the capability of CD4+ T cells to recognize a target with specific HLA class II polymorphisms as allogeneic, it may be relevant to study the frequency of CD4+ T cells and to examine the ability of these CD4+ $T$ cells to secrete inflammatory cytokines.

\section{Epitopes in both the alpha and beta chain regulate $T$ cell allorecognition}

Polymorphic positions in the peptide binding domain of the beta chain can influence T cell allorecognition. However, the mechanism directing allorecognition cannot be resolved by epitopes in the beta chain ${ }^{13-17}$. Interestingly, specific polymorphic amino acid residues in the alpha chain are also suggested to influencethe magnitude of $\mathrm{T}$ cell alloreactivity (chapter 4). In addition, preliminary clinical data revealed an important role for the polymorphic amino acid residue 31 in the HLA-DP alpha chain. Patients receiving a transplant from donors having only Met $(\mathrm{M})$ at amino acid residue 31 were associated with a lower risk of acute GVHD when compared to patients receiving a transplant from donors having $G \ln (Q)$ only or $G \ln +$ Met $(Q+M)$ (Figure 9.1). These preliminary data are consistent with two other functional studies where HLA-DPA1 allele background was demonstrated to affect $T$ cell recognition ${ }^{25,36}$, and a clinical study 
describing an association between HLA-DPA1 mismatching and survival ${ }^{37}$. The functional role of HLA-DPA1 is highlighted even more in disease association studies, as HLA-DPA1 alleles are correlated to disease status ${ }^{38-40}$. As functional studies using HLADP specific $T$ cell clones consider the beta chain as the only restricting element in stimulating HLA-DP specific alloresponses, our results on the functional role of the alpha chain provide new insights in understanding HLA-DP alloreactivity.

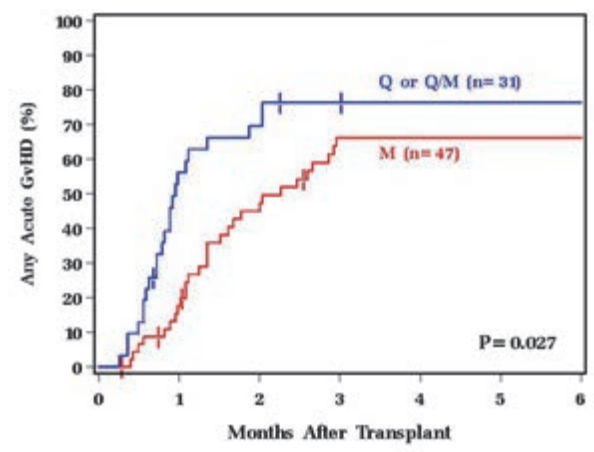

Figure 9.1 The presence of a Gln (Q)at aa position 31 in the DP molecule is associated with a deleterious effect on acute GVHD. Shown on the $y$-axis is the percentage of patients experiencing acute GVHD after a HSCT from an unrelated donor. The blue line represents patients receiving a transplant from a 10/10 HLA matched donor with $Q$ or $\mathrm{Gln}+\mathrm{Met}(\mathrm{Q}+\mathrm{M})$ at aa position 31 and the red line represents patients receiving a transplant from a donor with only a Met (M) at aa position 31.

As previously mentioned, an algorithm defining permissive and non-permissive mismatches was established by the group of Fleischhauer ${ }^{21}$. Within the first permissive allele group of the algorithm, five out of six alleles are associated with HLA-DPA ${ }^{*}$ 02:01, also pointing in the direction of a role for the alpha chain in $\mathrm{T}$ cell allorecognition. As polymorphism in both chains of the HLA-DP molecule can modify the alloreactive response, a combination of specific epitopes in both chains could determine whether a peptide is able to bind and if the TCR is able to interact with the HLA molecule. Moreover, MHC class I molecules with a high number of mismatches are not able to induce an alloreactive $T$ cell response, as positive thymic selection limits the capacity to recognize allogeneic $\mathrm{MHC}$ molecules whose structure and sequence have diverged extensively from their own ${ }^{41}$. Although speculative, this theory of too many mismatches impairing $T$ cell interaction could also hold true for mismatches in the alpha and beta chain of HLA-DP.

Overall, a combination of specific epitopes in the alpha- and beta chain may determine peptide binding or binding affinity of the TCR to the HLA/peptide complex. Possibly, too many amino acid differences may prevent the $T$ cell from interacting with the HLA 
molecule. It would be interesting to study these concepts more profoundly in functional $T$ cell studies by investigating the combination of specific amino acid residues in the alpha and beta chain by mutation analyses. In addition, it may be relevant to investigate the number of amino acid differences relevant for TCR binding. This will help to understand which mismatch combinations should be avoided and how to define the acceptable mismatches in stem cell transplantation.

\section{Future directions}

Evidence is growing demonstrating the need for defining the immunogenic HLA-DP epitopes and emphasizes that epitope matching should be considered instead of allele matching. This thesis underlines the functional relevance for polymorphism in both the alpha and beta chain of the HLA-DP molecule and highlights the importance of considering HLA-DP in stem cell transplantation. The DPA1 genotype (especially presence or absence of Gln at aa31) of the donor could provide us with more information on the risk of developing GVHD following stem cell transplantation in a 10/10 HLA matched setting. However, a much larger patient-donor cohort is required to determine how to implement DPA1 polymorphism into the matching strategy and to define whether it would be beneficial to also match for DPA1. It should be assessed whether DPA1 matching on top of DPB1 matching (either allele matching or permissive allele matching) could exhibit additive effects on patient outcome. In addition, it would be interesting to analyze whether matching for DPA1 and DPB1 in patient-donor pairs mismatched for other loci can lower the risk of complications, and whether DPA1 genotype of the donor could be considered a prognostic factor for the development of GVHD. Furthermore, our results point out the need to study the influence of the combination of different polymorphisms in both the alpha and beta chain on $\mathrm{T}$ cell allorecognition. This could provide us with more information on the structural mechanism regarding $T$ cell alloreactivity and may provide a clearer view on the definition of permissive and non-permissive mismatches. Specifying acceptable mismatches will not only be relevant for HLA-DP but also for the other loci which are considered in the current matching procedure. Especially since for $20-40 \%$ of the patients a 9-10/10 HLA matched donor cannot be found, considering acceptable mismatches would increase the number of potential donors ${ }^{42}$. Characterizing the relevant epitopes in $T$ cell allorecognition for HLA-A, -B, -C, -DRB1 and -DQB1, in addition to already defined serological and cellular relevant epitopes, should be one of the main focuses in future HLA functional studies to understand the underlying mechanisms that control patient outcome after stem cell transplantation. 


\section{Discussion part II}

\section{Regulatory mechanisms of HLA-E expression}

HLA-E surface expression, which is dependent on the availability of HLA class I leader peptides (HLA-A, -B, -C and -G), inhibits the NKG2A dependent NK cell response ${ }^{43,44}$. We demonstrated that HLA-E polymorphism affects HLA-E surface expression level in lymphocytes and monocytes, as HLA-E*01:03 molecules are higher expressed on the cell surface than HLA-E*01:01 molecules (chapter 6$)$. This difference in expression level might be explained by the higher binding affinity of peptides to HLA-E*01:03 compared to $H L A-E^{*} 01: 01^{45}$. Not only the HLA-E genotype determines the level of surface expression but also the peptide sequence, since the magnitude of HLA-E induction on the surface varied per peptide. Incubation with the peptide derived from the Hsp60 protein results in very limited HLA-E surface expression in contrast to incubation with the HLA class I leader peptides and CMV derived peptides. Mickaelsson et al. ${ }^{46}$ demonstrated in HLA-E transfected cell lines that the Hsp60 peptide can bind and stabilize HLA-E on the surface, however was unable to inhibit the NK cell.

Generally, HLA class I molecules are known to bind cytosolic peptides in the endoplasmatic reticulum $(E R)^{47}$. Interestingly, we showed that exogenous peptide stimulation with HLA class I leader or CMV derived peptides induces translation of new HLA-E molecules, although not enhancing transcription. It could be hypothesized that the extracellular peptides either bind to HLA-E on the surface or that they are taken up by the cell by means of pinocytosis, as described for other $\mathrm{MHC}^{48,49}$, to bind to HLA-E in the ER. Although speculative, binding of the peptide to HLA-E may initiate a signaling transduction pathway triggering translation of HLA-E, as signaling upon ligation of $\mathrm{MHC}$ class I with $\mathrm{MHC}$ specific antibodies has been demonstrated ${ }^{50}$. It would be interesting to further investigate the involvement of signaling in regulating HLA-E surface expression. In addition, it would be intriguing to investigate if there is a role for microRNA in regulating HLA-E expression. For HLA-C it has been shown that polymorphisms in the $3^{\prime}$ untranslated region can stimulate binding of a specific microRNA, resulting in a lower surface expression level ${ }^{51}$. Since there are microRNA binding sites present in the 3'UTR region of HLA-E (data not published), it can be questioned whether this also affects the surface level of HLA-E. Hence, microRNA could represent an unresolved mechanism in the regulation of HLA-E expression. Overall, our study points out that HLA-E expression level can be regulated by the HLA-E polymorphism and the peptide sequence. Furthermore, our results reveal a role for extracellular peptides in inducing HLA-E translation to ensure stabilization of HLA-E on the cell surface.

\section{HLA-E interacts with NKG2A to distinguish self from non-self}

HLA-E modulates NK cell immunity via interaction with NKG2A and NKG2C. We showed that HLA-E peptide induced surface expression on PBMCs inhibits NKG2A+ NK cells with 
almost all HLA class I leader peptides (chapter 7), concordant with findings in HLA-E transfected cell lines ${ }^{44-46,52-57}$. In addition, the inhibition occurs in both NKG2A+ NKG2Cand NKG2A+NKG2C+NK cells, which corresponds to the observation that NKG2A exhibits a six fold higher binding affinity for HLA-E when compared to NKG $2 C^{52,58}$. Hence, these data illustrate that the NKG2A+ NK cells could play a relevant role in preventing autoreactivity as the high affinity of the inhibitory receptor for HLA-E/HLA class I leader peptide complexes prevents inappropriate responses against self. Our findings show that the level of NK cell inhibition is comparable between the peptides although some peptides result in a higher HLA-E surface expression than others, which indicates that if HLA-E expression is above a certain threshold the NK cell is not inhibited any further by NKG2A. This indicates that the NK cell can respond better to variations in HLA-E expression level when expression is low and suggests that if HLA-E expression would fall below the threshold, for example due to viral infection, the NK cell will be released from its inhibiting signal. Interestingly, the absence of HLA-E is not the only factor that can cause NKG2A dependent NK cell activation, as we showed that Hsp60 and C17 peptides fail to inhibit NKG2A+ NK cells. Our observation on the Hsp60 peptide is in line with Mickaelsson et al. ${ }^{46}$ who showed that HLA-E/Hsp60 complex abrogates interaction with NKG2A. In addition, Hsp60 peptide could compete with other available endogenous peptides for binding to HLA-E. Hence, these findings may represent a mechanism for eliminating stressed cells. The $\mathrm{C} 17$ peptide upregulated HLA-E surface expression, from which one would expect NK cell inhibition via NKG2A. Nevertheless, this peptide is the only one having a Gln at position 5 and in mutation assays it has been shown that this position is crucial for NKG2A interaction ${ }^{46,54}$. The observation that not all peptide sequences inhibit the NK cell could be an additional defense mechanism against viruses. Some viruses e.g. $\mathrm{CMV}^{59}$ and $\mathrm{HIV}^{60}$, encode HLA-E binding peptides to ensure HLA-E stabilization on the cell surface. Meaning that in those cases HLA-E upregulation will inhibit the NK cell, which will favor viral survival. Therefore, the inability of certain divergent peptide sequences to inhibit NK cell killing could represent a way of the immune system to antagonize this survival mechanism by viruses.

\section{HLA-E regulates NKG2C+ NK cell responses by presentation of a restricted peptide repertoire}

In contrast to NKG2A, the NKG2C receptor only interacts with HLA-E when in combination with a restricted peptide repertoire (chapter 7), as we and others 52,61 showed that only the HLA-G leader peptide (G peptide) induces potent NKG2C+ NK cell responses. Under normal conditions HLA-G is not expressed on the cell surface. However during viral infection, such as HIV and CMV, the classical HLA class I molecules are downregulated whereas HLA-G is expressed on the cell surface ${ }^{62-64}$. During CMV infection the NKG2C+CD57+ NK cell subset is expanded ${ }^{65-68}$, however the ligand that is the driving force behind this expansion is unknown. Based on our results describing the 
HLA-G leader peptide as a potent inducer of NKG2C+NK cell activation, and the knowing that HLA-G is upregulated during viral infection, it can be suggested that the HLA-E/G peptide complex plays a role in the expansion of NKG2C+NK cells during CMV infection.

HLA-E and HLA-G are both expressed in throphoblasts in addition to HLA-F and low levels of HLA-C $\mathrm{C}^{69}$. The throphoblasts are targets for the decidual NK (dNK) cells, which constitute approximately $70 \%$ of the lymphocyte population in the decidua of pregnant women $^{69}$. These dNK cells express NKG2A and NKG2C on the cell surface ${ }^{70}$ and can interact with HLA-E on throphoblasts ${ }^{71}$. CMV is the most common cause of intrauterine viral infections and a known cause of severe birth defects or fetal death ${ }^{72}$. During normal pregnancy, the dNK cells are mainly producers of cytokines/chemokines and angiogenic factors to support successful placentation and materno-fetal immune tolerance ${ }^{73-79}$. Nevertheless, dNK cells become cytotoxic effectors upon exposure to HCMV-infected autologous decidual fibroblasts, by which NKG2D and the NKG2C or NKG2E activating receptors are involved in the acquired cytotoxic function (80). Therefore, it is intriguing to speculate whether the NKG2C+NK cell subset directed against HLA-E bound to CMV associated peptides on throphoblasts plays a role in the defense against CMV infection during pregnancy.

In addition to the induction of NKG2C+ NK cell activation upon interaction with the HLA-E/G complex, we also observed internalization of the NKG2C receptor. For NKG2D and $\mathrm{CD} 3 \gamma$, internalization of the receptor upon ligand interaction was already proven $^{81,82}$. Since NKG2C contains the same di-leucine motif (DxxxLL) as CD3 $\gamma$, crucial for internalization ${ }^{83}$, we suggest that the NKG2C receptor is internalized in a similar manner. Internalization of the activating receptor, when in interaction with this specific ligand/peptide combination, could function as a restraining element to prevent excessive activation of the NK cells.

Cytosolic peptides generated by the proteasome are transported to the ER by means of the transporter associated with antigen processing (TAP) and these peptides are further processed by aminopeptidases (e.g. ERAP-1) ${ }^{84,85}$. Viruses, such as CMV, can inhibit TAP and ERAP-1 to impair HLA class I cell surface expression ${ }^{86,87}$ to evade T cell recognition. However, in TAP deficient cells it has been shown that a unique peptide repertoire can still bind to HLA-E ${ }^{88}$ and inhibition of ERAAP, the murine homolog of ERAP-1, rapidly induces presentation of a specific peptide sequence by $Q A-1$, the murine homolog of HLA-E ${ }^{89}$. Therefore, it would be interesting to study if the specific peptide repertoire expressed in case of an impaired antigen processing pathway, plays a role in regulating NKG2C+ NK cell function during a viral challenge.

These findings justify further functional studies on the role of HLA-E bound with the HLA-G leader peptide, pathology associated peptides or peptides expressed in case of an impaired antigen processing pathway in the regulation of NKG2C+NK cell function. Eventually, these experiments could lead to a better understanding of anti-viral NK cell responses and could represent a basis for new therapeutic strategies in treating viral infections following stem cell transplantation. 


\section{The role of extracellular peptides in modulating the immune function via} HLA-E

Cytosolic peptides derived from intracellular proteins are generated in the proteasome and are transported to the endoplasmatic reticulum where they bind to available HLA class I molecules. These HLA/peptide complexes are then transported to the cell surface $^{47}$. So, generally HLA class I molecules are known to bind intracellular peptides for presentation on the cell surface. We demonstrated that exogenous peptide stimulation can enhance HLA-E specific translation and can induce HLA-E on the cell surface for presentation to the NK cell (chapter 6 en 7). The HLA-E/peptide complex can either induce or inhibit the NK cell response depending on the nature of the peptide and the expressed NK cell receptor repertoire. Therefore, our findings illustrate that extracellular peptides are able to modulate NK cell responsiveness via presentation by HLA-E, although the role in-vivo remains to be defined. Since it has been shown that necrotic cells can release stress proteins into the surrounding environment ${ }^{90}$, it would be interesting to study whether during necrosis also stress or pathogenic peptides are released in the extracellular fluids which consequentially can bind to HLA on bystander cells to modulate NK or T cell function. The psychological relevance of extracellular peptides has been demonstrated, as extracellular peptides can appear upon regurgitation of endosomally processed peptides at the cell surface ${ }^{91}$. In that way, neutrophils have been described to process phagocytosed bacteria, regurgitate the peptide and indirectly activate bacterial-specific CD8+ T cells after presentation of the regurgitated peptide on $\mathrm{MHC}$ class I of neighboring macrophages ${ }^{92}$. Presumably, regurgitation of peptides from bacteria or phagocytosed necrotic- or stressed-cells could make these peptides extracellularly available.

As NK cells are known to regulate adaptive immune responses via cytokine secretion ${ }^{93}$, killing of activated $\mathrm{T}$ cells ${ }^{94}$ and killing of naïve and allogeneic dendritic cells ${ }^{95,96}$, it would be interesting to study if extracellular peptide presentation by HLA-E may represent a new pathway by which NK cells can modulate adaptive immunity.

\section{Clinical implication of HLA-E polymorphism}

HLA-E polymorphism is an important regulator of HLA-E surface expression (chapter 6). As mentioned before, we could clearly demonstrate that HLA-E surface expression levels are higher on lymphocytes and monocytes from individuals homozygous for HLA-E*01:03 when compared to lymphocytes and monocytes from individuals homozygous for HLA-E*01:01. Interestingly, we could not observe a correlation between HLA-E polymorphism and NK cell function as the lower HLA-E expression in HLA-E*01:01 did not influence the level of NK cell inhibition (chapter 7). In addition, as earlier mentioned, we observed comparable levels of NK cell inhibition between the different peptides, although the level of HLA-E stabilization on the surface between the peptides varied. Our findings illustrate that NK cell inhibition via HLA-E does not occur in a strictly linear manner. Rather, they suggest that above a certain threshold a higher 
level of surface HLA-E does not inhibit the NK cell response any further. However, it should be kept in mind that we induce HLA-E stabilization with a relatively high peptide concentration, since we aimed to reach an expression plateau of HLA-E on the cell surface. In the in-vivo situation the level of surface HLA-E during a pathogenic challenge could vary. For example, when HLA-E is downregulated due to viral infection, HLA-E*01:01 encoded surface expression could fall sooner below the threshold than HLA-E*01:03 encoded expression. This could explain our results in unrelated stem cell transplantation, were we showed that the presence of HLA-E*01:03 is associated with a higher risk of infection (chapter 8). Although the population size was relatively small but associations were significant, this is currently confirmed in an independent second group of transplanted patients. These results implicate that virally infected target cells which express HLA-E*01:03 are more protected against NK cell lysis, due to a higher expression, and thus have a higher change of survival. By contrast, the presence of HLA-E*01:03 in the donor is associated with a lower risk of severe acute GVHD (chapter 8). This observation was in line with previous studies ${ }^{97-99}$, although one group described no effect ${ }^{100}$ and others described impact on survival ${ }^{101}$ or relapse ${ }^{102}$ only. One can speculate that post-transplantation, the higher surface expression of HLA-E*01:03 on patient cells could confine a more effective protection against NK cell killing than HLA-E*01:01. Thus, HLA-E is assumed to play a dual role in stem cell transplantation; HLA-E*01:03 genotype seems to have a deleterious effect on infections, whereas HLA-E*01:03 seems to exhibit a protective effect regarding GVHD. From these findings it can be hypothesized that HLA-E genotype in patient and the donor is a prognostic marker for the occurrence of GVHD and infections. However, a much larger patient population is needed to strengthen this statement and to unravel if HLA-E genotype also affects survival and relapse as has been suggested by others.

It should be kept in mind that HLA-E does not only interact with NK cells but also with the TCR and NKG2 receptors on a subset of T cells ${ }^{103-106}$. Therefore, T cells recognizing peptides in the context of HLA-E could also play a role in the development of posttransplantation complications. As HLA-E/CMV specific CD8+ T cells have been isolated from human blood and these $T$ cells were able to recognize CMV peptides in a HLA-E restricted fashion in-vitro ${ }^{105,107}$, it would be interesting to investigate whether HLA-E polymorphism or specific HLA-E binding peptides play a role in the induction of HLA-E specific $T$ cell responses during viral infection.

\section{Future directions}

Based on our functional and clinical data it becomes more and more clear how important HLA-E is in tuning immune responses, especially via NK cell function. HLA-E expression and the peptide bound to HLA-E represent crucial factors determining the magnitude of NKG2 dependent NK cell responses. Whereas the NKG2A+ NK cells are mainly important in homeostasis, it became clear that NKG2C+ NK cell activation is stimulated upon interaction with HLA-E when bound with a restricted peptide 
repertoire. It would be intriguing to further explore in an ex-vivo co-culture system, which peptides are able to induce NKG2C+ NK cell responses, proliferation and cytokine secretion, and whether these NK cells are able to react against virally infected cells. Data gained from these experiments may provide new knowledge on how to boost antiviral NK cell responses which may be relevant for the development of new treatment options for viral infections post-transplantation. Furthermore, our findings shed a new light on the role of HLA-E in patient outcome following unrelated HSCT in a 10/10 HLA matched setting. HLA-E matching between patient and donor can decrease the risk of GVHD and enhance the occurrence of neutrophil engraftment. In addition, the HLA-E genotype of patient and donor could tell us more about the risk of infections and GVHD in the period following stem cell transplantation. To more profoundly explore the impact of HLA-E genotype on the occurrence of the different types of infections it is required to analyze the influence of HLA-E polymorphism prospectively in a much larger patient-donor cohort with a precise monitoring of infectious events. By using a larger number of patient-donor pairs, also including transplants matched for less than 10/10 loci, will allow us to address the questions such as whether HLA-E matching can improve patient outcome in a setting where other HLA loci are mismatched, and whether HLA-E genotype can be used as a prognostic marker for the risk of post-transplantation complications. 


\section{Concluding remark}

Stem cell transplant patients and their donors are preferably matched for HLA-A, -B, -C, -DRB1 and -DQB1 on both chromosomes, however still too many patients experience post-transplant complications despite this matching strategy. Based on this thesis it becomes evident that considering HLA-DP and HLA-E additional to 10/10 HLA matching can significantly improve patient outcome following stem cell transplantation by decreasing the occurrence of GVHD and infections. Furthermore, HLA-E genotype of patient and donor can be considered a marker for predicting the risk of GVHD and infection. It is needed to verify these findings in a large multi-centric study, to investigate if matching for HLA-DP and HLA-E could overcome the deleterious effects in HLA mismatched patients and to explore the effect of HLA-E genotype on the different types of GVHD and infection.

Based on our functional assays we can postulate that both the alpha and beta chain of HLA-DP affect $T$ cell alloreactivity. Therefore, further exploring the functional units of HLA-DPA1 and HLA-DPB1 can significantly contribute to defining permissive and nonpermissive mismatches, which eventually will enhance the donor pool when considering HLA-DP for improving patient outcome. With respect to HLA-E, we demonstrate that HLA-E induces NKG2C+ NK cell responses when presenting specific peptides. We propose that studying the role of pathological associated peptides in inducing NKG2C+ NK cells responses against viral infections could provide new therapeutic options for treating viral infections following transplantation. Overall, this thesis provides new knowledge on the role of HLA-E and HLA-DP in transplantation related immune responses and new evidence which highlights the importance of considering HLA-E and HLA-DP in the matching strategies in stem cell transplantation in order to decrease the risk of post-transplant complications. 


\section{References}

1. Petersdorf EW. Optimal HLA matching in hematopoietic cell transplantation. Curr Opin Immunol. 2008;20:588-93.

2. Fleischhauer K, Zino E, Mazzi B, Sironi E, Servida P, Zappone E, Benazzi E, Bordignon C. Peripheral blood stem cell allograft rejection mediated by CD4(+) T lymphocytes recognizing a single mismatch at HLADP beta $1^{*}$ 0901. Blood. 2001;98:1122-6.

3. Varney MD, Lester S, McCluskey J, Gao X, Tait BD. Matching for HLA DPA1 and DPB1 alleles in unrelated bone marrow transplantation. Hum Immunol. 1999;60:532-8.

4. Petersdorf EW, Gooley T, Malkki M, Anasetti C, Martin P, Woolfrey A, Smith A, Mickelson E, Hansen JA. The biological significance of HLA-DP gene variation in haematopoietic cell transplantation. Brit J Haematol. 2001;112:988-94.

5. Shaw BE, Gooley TA, Malkki M, Madrigal JA, Begovich AB, Horowitz MM, Gratwohl A, Ringdén O, Marsh SG, Petersdorf EW. The importance of HLA-DPB1 in unrelated donor hematopoietic cell transplantation. Blood. 2007;110:4560-6.

6. Loiseau P, Espérou H, Busson M, Sghiri R, Tamouza R, Hilarius M, Raffoux C, Devergie A, Ribaud P, Socié G, Gluckman E, Charron D. DPB1 disparities contribute to severe GVHD and reduced patient survival after unrelated donor bone marrow transplantation. Bone Marrow Transplant. 2002;30:497-502.

7. Ludajic K, Balavarca Y, Bickeböller H, Pohlreich D, Kouba M, Dobrovolna M, Vrana M, Rosenmayr A, Fischer GF, Fae I, Kalhs P, Greinix HT. Impact of HLA-DPB1 allelic and single amino acid mismatches on HSCT. Br J Haematol. 2008;142:436-43.

8. Shaw BE, Potter MN, Mayor NP, Pay AL, Smith C, Goldman JM, Prentice HG, Marsh SG, Madrigal JA. The degree of matching at HLA-DPB1 predicts for acute graft-versus-host disease and disease relapse following haematopoietic stem cell transplantation. Bone Marrow Transplant. 2003;31:1001-8.

9. Shaw BE, Marsh SG, Mayor NP, Russell NH, Madrigal JA. HLA-DPB1 matching status has significant implications for recipients of unrelated donor stem cell transplants. Blood. 2006;107:1220-6.

10. Kawase T, Matsuo K, Kashiwase K, Inoko H, Saji H, Ogawa S, Kato S, Sasazuki T, Kodera Y, Morishima Y; Japan Marrow Donor Program. HLA mismatch combinations associated with decreased risk of relapse: implications for the molecular mechanism. Blood. 2009;113:2851-8.

11. Shaw BE, Mayor NP, Russell NH, Apperley JF, Clark RE, Cornish J, Darbyshire P, Ethell ME, Goldman JM, Little AM, Mackinnon S, Marks DI, Pagliuca A, Thomson K, Marsh SG, Madrigal JA. Diverging effects of HLA-DPB1 matching status on outcome following unrelated donor transplantation depending on disease stage and the degree of matching for other HLA alleles. Leukemia. 2010;24:58-65.

12. Flomenberg N, Baxter-Lowe LA, Confer D, Fernandez-Vina M, Filipovich A, Horowitz M, Hurley C, Kollman C, Anasetti C, Noreen H, Begovich A, Hildebrand W, Petersdorf E, Schmeckpeper B, Setterholm M, Trachtenberg E, Williams T, Yunis E, Weisdorf D. Impact of HLA class I and class II high-resolution matching on outcomes of unrelated donor bone marrow transplantation: HLA-C mismatching is associated with a strong adverse effect on transplantation outcome. Blood. 2004;104:1923-30.

13. Cesbron A, Moreau P, Milpied N, Harousseau JL, Muller JY, Bignon JD. Crucial role of the third and fourth hypervariable regions of HLA-DPB1 allelic sequences in the mixed lymphocyte reaction. Hum Immunol. 1992;33:202-7.

14. Cesbron A, Moreau P, Cheneau ML, Cury S, Milpied N, Muller JY, Harousseau JL, Bignon JD. Crucial role of the third and fourth hypervariable regions of HLA-DPB1 allelic sequences in primary mixedlymphocyte reaction: application in allogeneic bone marrow transplantation. Transplant Proc. 1993;25:1232-3.

15. Naruse TK, Nose Y, Kagiya M, Liao G, Nabeya N, Kimura M, Isshiki G, Inoko H. Cloned primed lymphocyte test cells recognize the fourth, fifth, and sixth hypervariable regions at amino acid positions 65-87 of the DPB1 molecule. Hum Immunol. 1995;42:123-30.

16. Nicholson I, Varney M, Kanaan C, Grigg A, Szer J, Tiedemann K, Tait BD. Alloresponses to HLA-DP detected in the primary MLR: correlation with a single amino acid difference. Hum Immunol. 1997;55:163-9.

17. Díaz G, Amicosante M, Jaraquemada D, Butler RH, Guillén MV, Sánchez M, Nombela C, Arroyo J. Functional analysis of HLA-DP polymorphism: a crucial role for DPbeta residues 9, 11, 35, 55, 56, 69 and 84-87 in T cell allorecognition and peptide binding. Int Immunol. 2003;15:565-76. 
18. Kawase T, Morishima Y, Matsuo K, Kashiwase K, Inoko H, Saji H, Kato S, Juji T, Kodera Y, Sasazuki T; Japan Marrow Donor Program. High-risk HLA allele mismatch combinations responsible for severe acute graft-versus-host disease and implication for its molecular mechanism. Blood. 2007;110:2235-41.

19. Ludajic K, Balavarca Y, Bickeböller H, Pohlreich D, Kouba M, Dobrovolna M, Vrana M, Rosenmayr A, Fischer GF, Fae I, Kalhs P, Greinix HT. Impact of HLA-DPB1 allelic and single amino acid mismatches on HSCT. Br J Haematol. 2008;142:436-43.

20. Fleischhauer K, Shaw BE, Gooley T, Malkki M, Bardy P, Bignon JD, Dubois V, Horowitz MM, Madrigal JA, Morishima Y, Oudshoorn M, Ringden O, Spellman S, Velardi A, Zino E, Petersdorf EW; International Histocompatibility Working Group in Hematopoietic Cell Transplantation. Effect of T-cell-epitope matching at HLA-DPB1 in recipients of unrelated-donor haemopoietic-cell transplantation: a retrospective study. Lancet Oncol. 2012;13:366-74.

21. Zino E, Frumento G, Marktel S, Sormani MP, Ficara F, Di Terlizzi S, Parodi AM, Sergeant R, Martinetti M, Bontadini A, Bonifazi F, Lisini D, Mazzi B, Rossini S, Servida P, Ciceri F, Bonini C, Lanino E, Bandini G, Locatelli F, Apperley J, Bacigalupo A, Ferrara GB, Bordignon C, Fleischhauer K. A T-cell epitope encoded by a subset of HLA-DPB1 alleles determines nonpermissive mismatches for hematologic stem cell transplantation. Blood. 2004;103:1417-24.

22. Crocchiolo R, Zino E, Vago L, Oneto R, Bruno B, Pollichieni S, Sacchi N, Sormani MP, Marcon J, Lamparelli T, Fanin R, Garbarino L, Miotti V, Bandini G, Bosi A, Ciceri F, Bacigalupo A, Fleischhauer K; Gruppo Italiano Trapianto di Midollo Osseo, Cellule Staminale Ematopoietiche (CSE) e Terapia Cellulare; Italian Bone Marrow Donor Registry. Nonpermissive HLA-DPB1 disparity is a significant independent risk factor for mortality after unrelated hematopoietic stem cell transplantation. Blood. 2009;114: 1437-44.

23. Touzeau C, Gagne K, Sébille V, Herry P, Chevallier P, Folléa G, Devys A, Moreau P, Mohty M, Cesbron Gautier A. Investigation of the impact of HLA-DPB1 matching status in 10/10 HLA matched unrelated hematopoietic stem cell transplantation: results of a French single center study. Hum Immunol. 2012;73:711-4.

24. Vie H, Gaschet J, Milpied N. Permissive, nonpermissive HLA-DPB1 epitope disparities and the specificity of T cells infiltrating the skin during acute graft-versus-host disease. Blood. 2011;117:5779-81.

25. Rutten CE, van Luxemburg-Heijs SA, van der Meijden ED, Griffioen M, Oudshoorn M, Willemze R, Falkenburg JH. HLA-DPB1 mismatching results in the generation of a full repertoire of HLA-DPB1specific CD4+ T cell responses showing immunogenicity of all HLA-DPB1 alleles. Biol Blood Marrow Transplant. 2010;16:1282-92.

26. Rutten CE, van Luxemburg-Heijs SA, Halkes CJ, van Bergen CA, Marijt EW, Oudshoorn M, Griffioen M, Falkenburg JH. Patient HLA-DP-specific CD4+ T cells from HLA-DPB1-mismatched donor lymphocyte infusion can induce graft-versus-leukemia reactivity in the presence or absence of graft-versus-host disease. Biol Blood Marrow Transplant. 2013;19:40-8.

27. Rutten CE, van Luxemburg-Heijs SA, van der Meijden ED, Griffioen M, Oudshoorn M, Willemze R, Falkenburg JH. Both permissive and nonpermissive HLA-DPB1 mismatches can induce polyclonal HLADPB1 specific immune responses in vivo and in vitro. Blood. 2010;115:151-3.

28. Konig R, Shen X, Germain RN. Involvement of both major histocompatibility complex class II alpha and beta chains in CD4 function indicates a role for ordered oligomerization in T cell activation. J Exp Med. 1995;182:779-87.

29. Fleury S, Thibodeau J, Croteau G, Labrecque N, Aronson HE, Cantin C, Long EO, Sékaly RP. HLA-DR polymorphism affects the interaction with CD4. J Exp Med. 1995;182:733-41.

30. Xiao Y, Lazaro AM, Masaberg C, Haagenson M, Vierra-Green C, Spellman S, Dakshanamurthy S, Ng J, Hurley CK. Evaluating the potential impact of mismatches outside the antigen recognition site in unrelated hematopoietic stem cell transplantation: HLA-DRB1*1454 and DRB1*140101. Tissue Antigens. 2009;73:595-8.

31. Cammarota G, Scheirle A, Takacs B, Doran DM, Knorr R, Bannwarth W, Guardiola J, Sinigaglia F. Identification of a CD4 binding site on the beta 2 domain of HLA-DR molecules. Nature. 1992;356:799801.

32. Hanvesakul R, Maillere B, Briggs D, Baker R, Larche M, Ball S. Indirect recognition of T-cell epitopes derived from the alpha 3 and transmembrane domain of HLA-A2. Am J Transplant. 2007;7:1148-57.

33. Riberdy JM, Mostaghel E, Doyle C. Disruption of the CD4-major histocompatibility complex class II interaction blocks the development of CD4(+) T cells in vivo. Proc Natl Acad Sci U S A. 1998;95:4493-8. 
34. Mostaghel EA, Riberdy JM, Steeber DA, Doyle C. Coreceptor-independent T cell activation in mice expressing MHC class II molecules mutated in the CD4 binding domain. J Immunol. 1998;161:6559-66.

35. Gilfillan S, Shen X, Konig R. Selection and function of CD4+ T lymphocytes in transgenic mice expressing mutant MHC class II molecules deficient in their interaction with CD4. J Immunol. 1998;161:6629-37.

36. Gaston JS, Goodall JC, Young JL, Young SP. Effect of polymorphism of the HLA-DPA1 chain on presentation of antigenic peptides. Hum Immunol. 1997;54:40-7.

37. Schaffer M, Aldener-Cannava A, Remberger M, Ringden O, Olerup O. Roles of HLA-B, HLA-C and HLADPA1 incompatibilities in the outcome of unrelated stem-cell transplantation. Tissue Antigens. 2003;62: 243-50.

38. O'Brien TR, Kohaar I, Pfeiffer RM, Maeder D, Yeager M, Schadt EE, Prokunina-Olsson L. Risk alleles for chronic hepatitis B are associated with decreased mRNA expression of HLA-DPA1 and HLA-DPB1 in normal human liver. Genes Immun. 2011;12:428-33.

39. Diaz-Pena R, Castro-Santos P, Aransay AM, Bruges-Armas J, Pimentel-Santos FM, Lopez-Larrea C. Genetic study confirms association of Hla-Dpa1 *01:03 subtype with ankylosing spondylitis in Hla-B27positive populations. Hum Immunol. 2013;74:764-7.

40. Vermehren J, Lötsch J, Susser S, Wicker S, Berger A, Zeuzem S, Sarrazin C, Doehring A. A common HLADPA1 variant is associated with hepatitis $B$ virus infection but fails to distinguish active from inactive Caucasian carriers. PLoS One. 2012;7:e32605.

41. Heemskerk MB, Roelen DL, Dankers MK, van Rood JJ, Claas FH, Doxiadis II, Oudshoorn M. Allogeneic $\mathrm{MHC}$ class I molecules with numerous sequence differences do not elicit a CTL response. Hum Immunol. 2005;66:969-76.

42. Tiercy JM. Unrelated hematopoietic stem cell donor matching probability and search algorithm. Bone Marrow Res. 2012;2012:695018.

43. Lee N, Llano M, Carretero M, Ishitani A, Navarro F, López-Botet M, Geraghty DE. HLA-E is a major ligand for the natural killer inhibitory receptor CD94/NKG2A. Proc Natl Acad Sci U S A. 1998;95:5199-204.

44. Lee N, Goodlett DR, Ishitani A, Marquardt H, Geraghty DE. HLA-E surface expression depends on binding of TAP-dependent peptides derived from certain HLA class I signal sequences. J Immunol. 1998;160:4951-60.

45. Strong RK, Holmes MA, Li P, Braun L, Lee N, Geraghty DE. HLA-E allelic variants. Correlating differential expression, peptide affinities, crystal structures, and thermal stabilities. J Biol Chem. 2003;278:5082-90.

46. Michaelsson J, Teixeira de Matos C, Achour A, Lanier LL, Karre K, Soderstrom K. A signal peptide derived from hsp60 binds HLA-E and interferes with CD94/NKG2A recognition. J Exp Med. 2002;196:1403-14.

47. Neefjes J, Jongsma ML, Paul P, Bakke O. Towards a systems understanding of MHC class I and MHC class II antigen presentation. Nat Rev Immunol. 2011;11:823-36.

48. Day PM, Yewdell JW, Porgador A, Germain RN, Bennink JR. Direct delivery of exogenous MHC class I molecule-binding oligopeptides to the endoplasmic reticulum of viable cells. Proc Natl Acad Sci U S A. 1997;94:8064-9.

49. Brophy SE, Jones LL, Holler PD, Kranz DM. Cellular uptake followed by class I MHC presentation of some exogenous peptides contributes to T cell stimulatory capacity. Mol Immunol. 2007;44:2184-94.

50. Skov S. Intracellular signal transduction mediated by ligation of MHC class I molecules. Tissue Antigens. 1998;51:215-23.

51. Kulkarni S, Savan R, Qi Y, Gao X, Yuki Y, Bass SE, Martin MP, Hunt P, Deeks SG, Telenti A, Pereyra F, Goldstein D, Wolinsky S, Walker B, Young HA, Carrington M. Differential microRNA regulation of HLA-C expression and its association with HIV control. Nature. 2011;472:495-8.

52. Llano M, Lee N, Navarro F, García P, Albar JP, Geraghty DE, López-Botet M. HLA-E-bound peptides influence recognition by inhibitory and triggering CD94/NKG2 receptors: preferential response to an HLA-G-derived nonamer. Eur J Immunol. 1998;28:2854-63.

53. Maier S, Grzeschik M, Weiss EH, Ulbrecht M. Implications of HLA-E allele expression and different HLA-E ligand diversity for the regulation of NK cells. Hum Immunol. 2000;61:1059-65.

54. Miller JD, Weber DA, Ibegbu C, Pohl J, Altman JD, Jensen PE. Analysis of HLA-E peptide-binding specificity and contact residues in bound peptide required for recognition by CD94/NKG2. J Immunol. 2003;171:1369-75.

55. Braud VM, Allan DS, O'Callaghan CA, Söderström K, D'Andrea A, Ogg GS, Lazetic S, Young NT, Bell Jl, Phillips JH, Lanier LL, McMichael AJ. HLA-E binds to natural killer cell receptors CD94/NKG2A, B and C. Nature. 1998;391:795-9. 
56. Cheent KS, Jamil KM, Cassidy S, Liu M, Mbiribindi B, Mulder A, Claas FH, Purbhoo MA, Khakoo SI. Synergistic inhibition of natural killer cells by the nonsignaling molecule CD94. Proc Natl Acad Sci U SA. 2013;110:16981-6.

57. Brooks AG, Borrego F, Posch PE, Patamawenu A, Scorzelli CJ, Ulbrecht M, Weiss EH, Coligan JE. Specific recognition of HLA-E, but not classical, HLA class I molecules by soluble CD94/NKG2A and NK cells. J Immunol. 1999;162:305-13.

58. Kaiser BK, Barahmand-Pour F, Paulsene W, Medley S, Geraghty DE, Strong RK. Interactions between NKG2x immunoreceptors and HLA-E ligands display overlapping affinities and thermodynamics. J Immunol. 2005;174:2878-84.

59. Ulbrecht M, Martinozzi S, Grzeschik M, Hengel H, Ellwart JW, Pla M, Weiss EH. Cutting edge: the human cytomegalovirus UL40 gene product contains a ligand for HLA-E and prevents NK cell-mediated lysis. J Immunol. 2000;164:5019-22.

60. Nattermann J, Nischalke HD, Hofmeister V, Kupfer B, Ahlenstiel G, Feldmann G, Rockstroh J, Weiss EH, Sauerbruch T, Spengler U. HIV-1 infection leads to increased HLA-E expression resulting in impaired function of natural killer cells. Antivir Ther. 2005;10:95-107.

61. Vales-Gomez M, Reyburn HT, Erskine RA, Lopez-Botet M, Strominger JL. Kinetics and peptide dependency of the binding of the inhibitory NK receptor CD94/NKG2-A and the activating receptor CD94/NKG2-C to HLA-E. Embo J. 1999;18:4250-60.

62. Tripathi $P$, Agrawal S. The role of human leukocyte antigen E and G in HIV infection. Aids. 2007;21:1395404.

63. Lozano JM, González R, Kindelán JM, Rouas-Freiss N, Caballos R, Dausset J, Carosella ED, Peña J. Monocytes and T lymphocytes in HIV-1-positive patients express HLA-G molecule. Aids. 2002;16: 347-51.

64. Onno M, Pangault C, Le Friec G, Guilloux V, Andre P, Fauchet R. Modulation of HLA-G antigens expression by human cytomegalovirus: specific induction in activated macrophages harboring human cytomegalovirus infection. J Immunol. 2000;164:6426-34.

65. Béziat V, Dalgard $O$, Asselah T, Halfon P, Bedossa P, Boudifa A, Hervier B, Theodorou I, Martinot M, Debré P, Björkström NK, Malmberg KJ, Marcellin P, Vieillard V. CMV drives clonal expansion of NKG2C+ NK cells expressing self-specific KIRs in chronic hepatitis patients. Eur J Immunol. 2012;42:447-57.

66. Foley B, Cooley S, Verneris MR, Curtsinger J, Luo X, Waller EK, Anasetti C, Weisdorf D, Miller JS. Human cytomegalovirus (CMV)-induced memory-like NKG2C(+) NK cells are transplantable and expand in vivo in response to recipient CMV antigen. J Immunol. 2012;189:5082-8.

67. Gumá M, Budt M, Sáez A, Brckalo T, Hengel H, Angulo A, López-Botet M. Expansion of CD94/NKG2C+ NK cells in response to human cytomegalovirus-infected fibroblasts. Blood. 2006;107:3624-31.

68. Lopez-Vergès S, Milush JM, Schwartz BS, Pando MJ, Jarjoura J, York VA, Houchins JP, Miller S, Kang SM, Norris PJ, Nixon DF, Lanier LL. Expansion of a unique CD57NKG2Chi natural killer cell subset during acute human cytomegalovirus infection. Proc Natl Acad Sci U S A. 2011;108:14725-32.

69. Moffett-King A. Natural killer cells and pregnancy. Nat Rev Immunol. 2002;2:656-63.

70. Kusumi M, Yamashita T, Fujii T, Nagamatsu T, Kozuma S, Taketani Y. Expression patterns of lectin-like natural killer receptors, inhibitory CD94/NKG2A, and activating CD94/NKG2C on decidual CD56bright natural killer cells differ from those on peripheral CD56dim natural killer cells. J Reprod Immunol. 2006;70:33-42.

71. King A, Allan DS, Bowen M, Powis SJ, Joseph S, Verma S, Hiby SE, McMichael AJ, Loke YW, Braud VM. HLA-E is expressed on trophoblast and interacts with CD94/NKG2 receptors on decidual NK cells. Eur J Immunol. 2000;30:1623-31.

72. Cannon MJ. Congenital cytomegalovirus (CMV) epidemiology and awareness. J Clin Virol. 2009;46 Suppl 4:S6-10.

73. El Costa H, Casemayou A, Aguerre-Girr M, Rabot M, Berrebi A, Parant O, Clouet-Delannoy M, Lombardelli L, Jabrane-Ferrat N, Rukavina D, Bensussan A, Piccinni MP, Le Bouteiller P, Tabiasco J. Critical and differential roles of NKp46- and NKp30-activating receptors expressed by uterine NK cells in early pregnancy. J Immunol. 2008;181:3009-17.

74. Hanna J, Goldman-Wohl D, Hamani Y, Avraham I, Greenfield C, Natanson-Yaron S, Prus D, Cohen-Daniel L, Arnon TI, Manaster I, Gazit R, Yutkin V, Benharroch D, Porgador A, Keshet E, Yagel S, Mandelboim O.. Decidual NK cells regulate key developmental processes at the human fetal-maternal interface. Nat Med. 2006;12:1065-74. 
75. Keskin DB, Allan DS, Rybalov B, Andzelm MM, Stern JN, Kopcow HD, Koopman LA, Strominger JL. TGFbeta promotes conversion of CD16+ peripheral blood NK cells into CD16- NK cells with similarities to decidual NK cells. Proc Natl Acad Sci U S A. 2007;104:3378-83.

76. Koopman LA, Kopcow HD, Rybalov B, Boyson JE, Orange JS, Schatz F, Masch R, Lockwood CJ, Schachter $A D$, Park PJ, Strominger JL. Human decidual natural killer cells are a unique NK cell subset with immunomodulatory potential. J Exp Med. 2003;198:1201-12.

77. Le Bouteiller P, Siewiera J, Casart Y, Aguerre-Girr M, El Costa H, Berrebi A, Tabiasco J, Jabrane-Ferrat N. The human decidual NK-cell response to virus infection: what can we learn from circulating NK lymphocytes? J Reprod Immunol. 2011;88:170-5.

78. Santoni A, Carlino C, Gismondi A. Uterine NK cell development, migration and function. Reprod Biomed Online. 2008;16:202-10.

79. Vacca P, Cantoni C, Vitale M, Prato C, Canegallo F, Fenoglio D, Ragni N, Moretta L, Mingari MC. Crosstalk between decidual NK and CD14+ myelomonocytic cells results in induction of Tregs and immunosuppression. Proc Natl Acad Sci U S A. 2010;107:11918-23.

80. Siewiera J, El Costa H, Tabiasco J, Berrebi A, Cartron G, Le Bouteiller P, Jabrane-Ferrat N. Human cytomegalovirus infection elicits new decidual natural killer cell effector functions. PLoS Pathog. 2013;9:e1003257.

81. Groh V, Wu J, Yee C, Spies T. Tumour-derived soluble MIC ligands impair expression of NKG2D and Tcell activation. Nature. 2002;419:734-8.

82. Dietrich J, Hou X, Wegener AM, Pedersen LO, Odum N, Geisler C. Molecular characterization of the dileucine-based internalization motif of the T cell receptor. J Biol Chem. 1996;271:11441-8.

83. Borrego F, Kabat J, Sanni TB, Coligan JE. NK cell CD94/NKG2A inhibitory receptors are internalized and recycle independently of inhibitory signaling processes. J Immunol. 2002;169:6102-11.

84. Vyas JM, Van der Veen AG, Ploegh HL. The known unknowns of antigen processing and presentation. Nat Rev Immunol. 2008;8:607-18.

85. Haroon N, Inman RD. Endoplasmic reticulum aminopeptidases: Biology and pathogenic potential. Nat Rev Rheumatol. 2010;6:461-7.

86. Hansen $\mathrm{TH}$, Bouvier M. MHC class I antigen presentation: learning from viral evasion strategies. Nat Rev Immunol. 2009;9:503-13.

87. Kim S, Lee S, Shin J, Kim Y, Evnouchidou I, Kim D, Kim YK, Kim YE, Ahn JH, Riddell SR, Stratikos E, Kim VN, Ahn K.. Human cytomegalovirus microRNA miR-US4-1 inhibits CD8(+) T cell responses by targeting the aminopeptidase ERAP1. Nat Immunol. 2011;12:984-91.

88. Lampen MH, Hassan C, Sluijter M, Geluk A, Dijkman K, Tjon JM, de Ru AH, van der Burg SH, van Veelen PA, van Hall T. Alternative peptide repertoire of HLA-E reveals a binding motif that is strikingly similar to HLA-A2. Mol Immunol. 2013;53:126-31.

89. Nagarajan NA, Gonzalez F, Shastri N. Nonclassical MHC class Ib-restricted cytotoxic T cells monitor antigen processing in the endoplasmic reticulum. Nat Immunol. 2012;13:579-86.

90. Basu S, Binder RJ, Suto R, Anderson KM, Srivastava PK. Necrotic but not apoptotic cell death releases heat shock proteins, which deliver a partial maturation signal to dendritic cells and activate the NFkappa B pathway. Int Immunol. 2000;12:1539-46.

91. Song R, Harding CV. Roles of proteasomes, transporter for antigen presentation (TAP), and beta 2microglobulin in the processing of bacterial or particulate antigens via an alternate class I MHC processing pathway. J Immunol. 1996;156:4182-90.

92. Potter NS, Harding CV. Neutrophils process exogenous bacteria via an alternate class I MHC processing pathway for presentation of peptides to T lymphocytes. J Immunol. 2001;167:2538-46.

93. Martín-Fontecha A, Thomsen LL, Brett S, Gerard C, Lipp M, Lanzavecchia A, Sallusto F. Induced recruitment of NK cells to lymph nodes provides IFN-gamma for $\mathrm{T}(\mathrm{H}) 1$ priming. Nat Immunol. 2004;5:1260-5.

94. Waggoner SN, Cornberg M, Selin LK, Welsh RM. Natural killer cells act as rheostats modulating antiviral T cells. Nature. 2011;481:394-8.

95. Della Chiesa M, Vitale M, Carlomagno S, Ferlazzo G, Moretta L, Moretta A. The natural killer cellmediated killing of autologous dendritic cells is confined to a cell subset expressing CD94/NKG2A, but lacking inhibitory killer Ig-like receptors. Eur J Immunol. 2003;33:1657-66. 
96. Laffont S, Seillet C, Ortaldo J, Coudert JD, Guery JC. Natural killer cells recruited into lymph nodes inhibit alloreactive T-cell activation through perforin-mediated killing of donor allogeneic dendritic cells. Blood. 2008;112:661-71.

97. Tamouza R, Busson M, Rocha V, Fortier C, Haddad Y, Brun M, Boukouaci W, Bleux H, Socié G, Krishnamoorthy R, Toubert A, Gluckman E, Charron D. Homozygous status for HLA-E*0103 confers protection from acute graft-versus-host disease and transplant-related mortality in HLA-matched sibling hematopoietic stem cell transplantation. Transplantation. 2006;82:1436-40.

98. Ludajic K, Rosenmayr A, Faé I, Fischer GF, Balavarca Y, Bickeböller H, Kalhs P, Greinix HT. Association of HLA-E polymorphism with the outcome of hematopoietic stem-cell transplantation with unrelated donors. Transplantation. 2009;88:1227-8.

99. Hosseini E, Schwarer AP, Ghasemzadeh M. The impact of HLA-E polymorphisms in graft-versus-host disease following HLA-E matched allogeneic hematopoietic stem cell transplantation. Iran J Allergy Asthma Immunol. 2012;11:15-21.

100. Fürst D, Bindja J, Arnold R, Herr W, Schwerdtfeger R, Müller CH, Recker K, Schrezenmeier H, Mytilineos J. HLA-E polymorphisms in hematopoietic stem cell transplantation. Tissue Antigens. 2012;79:287-90.

101. Danzer M, Polin H, Pröll J, Haunschmid R, Hofer K, Stabentheiner S, Hackl C, Kasparu H, König J, Hauser $H$, Binder M, Weiss R, Gabriel C, Krieger O. Clinical significance of HLA-E*0103 homozygosity on survival after allogeneic hematopoietic stem-cell transplantation. Transplantation. 2009;88:528-32.

102. Hosseini E, Schwarer AP, Jalali A, Ghasemzadeh M. The impact of HLA-E polymorphisms on relapse following allogeneic hematopoietic stem cell transplantation. Leuk Res. 2013.

103. Heinzel AS, Grotzke JE, Lines RA, Lewinsohn DA, McNabb AL, Streblow DN, Braud VM, Grieser HJ, Belisle JT, Lewinsohn DM. HLA-E-dependent presentation of Mtb-derived antigen to human CD8+ T cells. J Exp Med. 2002;196:1473-81.

104. Gumá M, Busch LK, Salazar-Fontana LI, Bellosillo B, Morte C, García P, López-Botet M. The CD94/NKG2C killer lectin-like receptor constitutes an alternative activation pathway for a subset of CD8+ T cells. Eur J Immunol. 2005;35:2071-80.

105. Mazzarino P, Pietra G, Vacca P, Falco M, Colau D, Coulie P, Moretta L, Mingari MC. Identification of effector-memory CMV-specific T lymphocytes that kill CMV-infected target cells in an HLA-E-restricted fashion. Eur J Immunol. 2005;35:3240-7.

106. Muñoz-Cobo B, Solano C, Benet I, Costa E, Remigia MJ, de la Cámara R, Nieto J, López J, Amat P, GarciaNoblejas A, Bravo D, Clari MÁ, Navarro D. Functional profile of cytomegalovirus (CMV)-specific CD8(+) T cells and kinetics of NKG2C(+) NK Cells associated with the resolution of CMV DNAemia in allogeneic stem cell transplant recipients. J Med Virol. 2012;84:259-67.

107. Pietra G, Romagnani C, Mazzarino P, Falco M, Millo E, Moretta A, Moretta L, Mingari MC. HLA-Erestricted recognition of cytomegalovirus-derived peptides by human CD8+ cytolytic T lymphocytes. Proc Natl Acad Sci U S A. 2003;100:10896-901. 

Summary 


\section{Summary}

In the 1930's Peter Gorer and George Snell discovered that skin grafts between mice with identical Antigen II alleles were accepted, while mice with different Antigen II alleles rejected the skin transplant. The genes that were held responsible for these phenomenon were named the Major Histocompatibility locus. This is the first identification of the Major Histocompatibility Complex (MHC) present in vertebrates including humans, named the Human Leukocyte Antigen (HLA) system. The HLA system can be classified into HLA class I and class II genes located on the short arm of chromosome 6 (6p21.3). Since 1985, molecular techniques evolved and have been introduced to identify DNA polymorphism and to correlate DNA polymorphism with known cellular and serological specificities. Today almost 7000 HLA class I alleles and 2000 HLA class II alleles are known. Due to this high polymorphism, allele mismatches between patients and donors in stem cell transplantation is likely to occur. It is crucial to determine which mismatches are clinically relevant and which allele mismatch combinations are acceptable.

The HLA class I molecules can be classified into the classical HLA-A, -B and -C loci and the non-classical HLA-E, $-F$ and $-G$ loci and are known to present peptides to the CD8+ cytotoxic T lymphocyte or NK cell. The HLA class II genes can be classified into the HLA-DR, -DQ and -DP loci. The HLA class II molecules bind peptides and present them on the surface to the CD4+ T cell. Because of the high polymorphism of the HLA genes, a systematic nomenclature is coordinated by the WHO Nomenclature Committee.

In hematopoietic stem cell transplantation (HSCT) T cells from the donor have the potential to recognize patient HLA as foreign which can lead to a vigorous immune response, called graft-versus-host disease (GVHD). As the frequency of acute GVHD is directly related to the degree of mismatch between the HLA molecules, HSCT is being performed across patients and donors who preferably are matched for HLA-A, -B, -C, -DRB1 and -DQB1. Nevertheless, still 35-45\% will develop acute GVHD.

Two candidate loci that could be involved in transplantation related immune responses are HLA-DP and HLA-E. Evidence is accumulating describing HLA-DP as an important transplantation antigen. However, a functional view on HLA-DP allele matching status is required. HLA-E generally acts as a ligand to the inhibiting NKG2A and activating NKG2C NK cell receptors and a subset of $T$ cells. Knowledge on the impact of HLA-E polymorphism and expression level on the activation level of the various NKG2A and NKG2C expressing NK cell subsets in humans is lacking. Especially, the role of the activating NKG2C receptor is less well understood.

In chapter 2, all frequent and available non-frequent DPB1 alleles were full length sequenced using an RNA based approach from 148 samples representing 28 different DPB1 alleles from either Black, Caucasian or Oriental origin. We identified various DPB1 alleles with, in addition to the exon 2 polymorphism, polymorphisms in exons 1, 3, 4 and 5. Two alleles with identical exon 2 polymorphism but differing outside exon 2 
were identified in individuals of different ethnic groups. Moreover, based on this polymorphism outside exon 2 we defined one new allele.

In chapter 3, we explored the role of the previously identified polymorphism in exon 4 on $\mathrm{T}$ cell allorecognition. HLA-DP3, encoded by two transmembrane (TM) region variants, DPB1*03:01 and DPB1*104:01, was used as target for allogeneic CD4+ T cells. No significant differences were observed in cell surface expression levels of the two variants on B lymphoblastoid cell lines (BLCL), primary B cells or monocytes. Similar levels of CD4+ T cell activation were shown in response to HLA-DP3 encoded by DPB1*03:01 and DPB1*104:01, either endogenously on BLCL or after lentiveral-vector mediated transfer into the same cellular background. These data provide, for the first time, direct evidence for a limited functional role of a TM region polymorphism on expression and allorecognition of HLA-DP3.

In chapter 4, the effect of DPB1 polymorphism in region beyond exon 2 and the role of DPA1 polymorphism in CD4+ $\mathrm{T}$ cell allorecognition was explored. No significant differences in CD4+ T cell allorecognition levels could be demonstrated for any of the beyond exon 2 DPB1 variants studied. Interestingly, however, the mean fold change in CD4+ CD137+ cells was significantly higher when the target shared at least one DPA1 allele with the allogeneic stimulator, compared to targets having a distinct DPA1 background. Structural homology modeling suggested specific amino acid residues in the alpha chain, in particular position 31, to impact CD4+ T cell allorecognition of HLA-DP. Overall, our findings demonstrate relevance of DPA1 polymorphism in $\mathrm{T}$ cell alloreactivity.

In the second part of the thesis we studied the functional and clinical effects of HLA-E polymorphism and expression. To determine HLA-E polymorphism in healthy subjects and transplant patients, we developed various HLA-E typing techniques (chapter 5); the PCR-SSP method that uses sequence-specific primers, the PCR-SSO Luminex method, using sequence-specific probes attached to beads and the SBT method, where sequencing of the alleles is performed.

In chapter 6, the regulatory mechanisms of HLA-E expression were investigated in PBMCs of healthy volunteers. Basal and peptide induced HLA-E surface expression levels were higher in PBMC from HLA-E*01:03 homozygous subjects when compared to PBMC from HLA-E*01:01 homozygous subjects. HLA-E surface expression was not only dependent on the HLA-E genotype, but also on the peptide sequence. Interestingly, our results showed that peptide-induced HLA-E expression is regulated at translational level as extracellular peptide stimulation triggered the actual synthesis of new HLA-E molecules and as synthesis was inhibited by cycloheximide. This study provides new insides in the mechanism by which HLA-E expression level is regulated and underlines a new role for extracellular peptides in stabilizing HLA-E on the cell surface. 
In chapter 7, the functional consequences of HLA-E for NKG2A and NKG2C expressing NK cells were studied. While almost all peptides inhibited the NKG2A+ NK cell response in an HLA-E specific manner, only four out of eleven peptides enhanced the activation of the NKG2C+ NK cell subset; Incubation with CMV(I), A80 and B13 peptide resulted in a very moderate induction of the NKG2C+NK cell response, whereas the leader peptide derived from HLA-G (G peptide) highly enhanced the level of NKG2C+NK cell activation. In addition, the HLA-E:G peptide complex triggered NKG2C receptor internalization. This was evidenced by a reduction in the percentage of NKG2C+NK cells with the peptide which could be restored by addition of Bafilomycine. In conclusion, our study describes HLA-E as activating ligand to the NKG2C receptor only when it is complexed with a restricted set of peptides. Moreover, our study reveals a unique role for the leader peptide of HLA-G.

In chapter 8, the clinical implications of HLA-E polymorphism on patient outcome following unrelated HSCT were examined. HLA-E genotype was studied in 81 patients from a single center who underwent HSCT from a 10/10 HLA matched unrelated donor. Our findings revealed that HLA-E mismatching was associated with a less likely chance of neutrophil engraftment, and with a higher risk of severe acute GVHD when compared to HLA-E matching. Furthermore, the presence of HLA-E*01:03 in the donor was associated with less occurrence of severe acute GVHD. Regarding infections, the presence of HLA-E*01:03 in the recipient was associated with a higher risk of any and non-CMV infections. Our results suggest a role of HLA-E polymorphism and matching in the development of post-transplantation complications in HSCT and argue for a dual role of HLA-E in stem cell transplantation with respect to GVHD and infection.

The discussion of this thesis consists of two parts:

Our findings highlight that considering DPA1 genotype in stem cell transplantation could have beneficial effects on patient outcome, however a much larger patient-donor cohort is required to determine how to implement DPA1 polymorphism into the matching strategy and to define whether it would be beneficial to also match for DPA1. As we demonstrated that polymorphism in both the alpha and beta chain of the HLADP molecule can affect $T$ cell allorecognition, it can be proposed that a combination of specific epitopes in the alpha- and beta chain can define alloreactivity. Specifying acceptable mismatches would not only be relevant for HLA-DP but also for the other loci which are considered in the matching procedure. Especially as for 20-40\% a 9-10/10 HLA matched donor cannot be found, considering acceptable mismatches would increase the number of potential donors (chapter 9 part I).

With respect to HLA-E, we showed that only the HLA-G leader peptide induces potent $N K G 2 C+N K$ cell responses in the context of HLA-E. As previous studies demonstrated that NKG2C+ NK cells are expanded during CMV infection and HLA-G is upregulated on 
the cell surface following CMV infection, it could be suggested that the HLA-E/G complex plays a role in regulating the NKG2C+NK cell function during viral infection. Furthermore our results emphasize the relevance of HLA-E polymorphism in transplantation related complications following stem cell transplantation. However, as the number of our transplant population was small, it is required to verify these findings in a larger cohort. It would be of great value to examine whether considering HLA-E in the matching procedure, when mismatches in other loci are present, could improve patient outcome and whether the HLA-E genotype in patient and donor can be used as a prognostic marker for the risk of post-transplantation complications (chapter 9 part II). 
Samenvatting 
182 


\section{Samenvatting}

In de jaren 1930 ontdekten Peter Gorer en George Snell dat huidtransplantaten tussen muizen met identieke antigeen II allelen werden aanvaard terwijl muizen met verschillende antigeen II allelen de huidtransplantaten afstootten. De genen die verantwoordelijk waren voor dit fenomeen werden de Major Histocompatibility loci genoemd. Dit is de eerste identificatie van de Major Histocompatibility Complex (MHC) welk aanwezig is in alle gewervelde dieren. Bij de mens staat het bekend als het Humaan Leukocyten Antigeen (HLA) systeem. Het HLA-systeem kan worden ingedeeld in HLA klasse I en klasse II genen gelegen op de korte arm van chromosoom 6 (6p21.3) en het wordt gekenmerkt door een sterk polymorfisme. Dit betekent dat er van elk gen een groot aantal allelische vormen bestaat. Sinds 1985 zijn er technieken ontwikkeld en ingevoerd om DNA polymorfisme te identificeren en om dit polymorfisme met bekende cellulaire en serologische specificiteiten te correleren. Een serologische typering identificeert HLA antigenen op de celmembraan en toont de expressie van deze HLA moleculen aan. Vandaag de dag zijn bijna 7000 HLA klasse I allelen en 2000 HLA klasse II allelen geïdentificeerd. Omwille van het polymorfisme van de HLA genen, wordt een systematische nomenclatuur gecoördineerd door het WHO nomenclatuur comité. De hoge mate van polymorfisme kan een probleem vormen bij het vinden van een geschikte donor voor patiënten die een stamceltransplantatie nodig hebben. Het is namelijk waarschijnlijk dat donorcellen andere HLA allelen hebben dan de patiëntcellen. Dit wordt aangeduid als een mismatch tussen patiënt en donor. Het is van cruciaal belang om te bepalen welke mismatches wel en welke mismatches niet leiden tot complicaties na transplantatie.

De HLA klasse I genen kunnen worden ingedeeld in de klassieke HLA-A, -B en -C loci en de niet-klassieke HLA-E -F en -G loci. Deze genen coderen voor oppervlaktemoleculen die intracellulaire peptiden (bijv. afkomstig van een virus) presenteren op het celoppervlak aan de CD8+ cytotoxische T lymfocyten of aan de natural killer (NK) cellen. De HLA klasse Il genen kunnen worden ingedeeld in de loci HLA-DR, DQ- en -DP. De HLA klasse II moleculen binden extracellulaire peptiden (bijv. afkomstig van een bacterie) en presenteren deze peptiden op het celoppervlak aan de CD4+ T cel.

$\mathrm{Na}$ hematopoietische stamceltransplantatie (HSCT) kunnen T cellen van de donor het patiënt HLA en/of peptide als vreemd herkennen (alloreactiviteit genoemd). Dit kan tot een krachtige immuunreactie tegen de patiënt cellen leiden, genoemd graft-versushost-ziekte (GVHD). De frequentie van acute GVHD is direct gerelateerd aan de mate van mismatches tussen de patiënt en donor. Daarom wordt HSCT uitgevoerd tussen patiënten en donoren die bij voorkeur zijn gematched op basis van HLA-A, -B, -C, -DRB1 en -DQB1 allelen. Echter zal nog steeds $35-45 \%$ van de patiënten na transplantatie acute GVHD ontwikkelen.

Twee andere HLA loci die ook een rol zouden kunnen spelen bij transplantatie gerelateerde immuunreacties zijn HLA-DP en HLA-E. Steeds meer studies laten zien dat HLA-DP een rol speelt bij het ontstaan van complicaties na stamceltransplantatie. 
Echter een functionele kijk op HLA-DP matchen is verreist, aangezien de nomenclatuur van HLA-DP niet is gebaseerd op serologie zoals de andere loci en klinische studies niet eenduidig zijn over het effect van HLA-DP mismatchen. HLA-E fungeert over het algemeen als een ligand voor de remmende receptor NKG2A en de activerende receptor NKG2C op NK cellen. Kennis over de invloed van HLA-E polymorfisme en expressie op de functie van de verschillende NKG2A en NKG2C expreserende NK cel subsets in de mens is beperkt. Vooral de rol van de activerende NKG2C receptor is minder goed begrepen.

In hoofdstuk 2 zijn alle frequente en beschikbare niet-frequente DPB1 allelen met behulp van een RNA aanpak 'full length' gesequenced in 148 samples die 28 verschillende DPB1 allelen vertegenwoordigen van negroïde, kaukasische of oosterse oorsprong. We hebben verschillende DPB1 allelen geïdentificeerd met, naast het bekende exon 2 polymorfisme, polymorfisme in exonen 1, 3, 4 en 5. Verschillende nieuwe allel varianten met verschillen buiten exon 2 waren gevonden in samples behorende tot een bepaalde ethnische groep. Bovendien hebben we één nieuwe allel geïdentificeerd op basis van deze polymorfe posities buiten exon 2 .

In hoofdstuk 3 bestudeerden we de rol van eerder door ons geïdentificeerde polymorfisme in exon 4 op allogene T cel herkenning. Het HLA-DP3 antigeen, welk gecodeerd wordt door twee transmembraan (TM) regio varianten (DPB1*03:01 en DPB1*104:01), werd als target gebruikt voor allogene CD4+ T cellen. Geen significante verschillen werden waargenomen in celoppervlak expressie niveaus van de twee varianten op de $B$ lymfoblastoide cellijnen (BLCL), primaire B cellen of monocyten. Vergelijkbare niveaus van CD4+ $T$ cel activatie werden aangetoond in reactie op HLADP3 gecodeerd door DPB1*03:01 en DPB1*104:01. Deze gegevens leveren voor het eerst direct bewijs voor een beperkte functionele rol van TM regio polymorfisme op expressie en allogene T cel herkenning van HLA-DP3.

In hoofdstuk 4 werd het functionele effect van DPB1 polymorfisme in de gebieden buiten exon 2 bestudeerd en werd de rol van DPA1 polymorfisme op allogene CD4+ T cel herkenning onderzocht. Geen significante verschillen in CD4+ T cel herkenning waren zichtbaar tussen de cellijnen met identieke exon 2 sequentie maar verschillen in de andere exonen. Interessant is echter dat het gemiddelde percentage CD4+ CD137+ cellen aanzienlijk hoger was indien de cellijnen ten minste één DPA1 allel deelde met de allogene stimulator, vergeleken met cellijnen die een geheel andere DPA1 achtergrond hadden. Structurele modellering illustreerde specifieke aminozuur residuen in de alpha keten van het HLA-DP molecuul, met name positie 31, die de CD4+ T cel herkenning van HLA-DP zouden kunnen beïnvloeden. Concluderend, tonen onze bevindingen de relevantie van DPA1 polymorfisme in allogene $T$ cel herkenning aan. 
In het tweede deel van het proefschrift bestudeerden we de functionele en klinische effecten van HLA-E polymorfisme en expressie. Om HLA-E polymorfisme te kunnen bepalen in gezonde proefpersonen en in transplantatie patiënten ontwikkelden we verschillende HLA-E typeringstechnieken (hoofdstuk 5); de PCR-SSP methode waarbij sequence-specifieke primers worden gebruikt, de PCR-SSO Luminex methode, welk gebruik maakt van sequence-specifieke probes gekoppeld aan beads en de SBT methode, waarbij de allelen worden gesequenced.

In hoofdstuk 6 werd de regulatie van HLA-E expressie in perifere bloed lymfocyten van proefpersonen bestudeerd. Hierbij werd gevonden dat HLA-E expressie hoger was in individuen homozygoot voor HLA-E*01:03 dan in personen homozygoot voor HLA-E*01:01 en dat de level van expressie ook afhankelijk was van het type peptide. Verder lieten we zien dat HLA-E expressie werd gereguleerd op translationeel niveau, aangezien exogene peptide stimulatie de aanmaak van nieuwe HLA-E moleculen induceerde en cycloheximide de aanmaak van nieuwe HLA-E moleculen kon stopzetten. Deze studie laat zien dat HLA-E expressie gereguleerd wordt door zowel het polymorfisme en het type peptide. Verder benadrukt het een nieuwe rol voor extracellulaire peptides in de regulatie van HLA-E expressie.

In hoofdstuk 7 werd het effect van HLA-E op de functie van verschillende NK cel groepen onderzocht. Peptide geïnduceerde HLA-E expressie, na stimulatie met bijna alle HLA klasse I peptiden, verlaagde het activatieniveau van NKG2A+ NK cellen. Daarentegen hadden slechts enkele peptiden effect op de NKG2C+NKG2A- NK cel activatie. CMV(I), A80 en B13 peptiden zorgde voor een lichte verhoging van activatie, waar het HLA-G leider peptide (G peptide) zorgde voor een sterke toename van NK cel activatie. Verder veroorzaakte het HLA-E/G peptide complex internalisatie van de NKG2C receptor. Deze bevindingen laten zien dat HLA-E NK cellen enkel kan activeren wanneer het bepaalde peptiden presenteert en verduidelijkt een unieke rol voor het HLA-G leider peptide.

In hoofdstuk 8 werden de klinische implicaties van HLA-E polymorfisme op het welzijn van transplantatiepatiënten na ongerelateerde HSCT bestudeerd. Het HLA-E genotype werd bestudeerd in 81 patiënten die HSCT ondergingen met een 10/10 HLA gematchte niet-verwante donor. Uit onze bevindingen bleek dat een HLA-E mismatch in vergelijking met een HLA-E match werd geassocieerd met een kleinere kans op neutrofiele engraftment en met een hoger risico op ernstige acute GVHD. De aanwezigheid van HLA-E*01:03 in de donor was geassocieerd met een kleiner risico op ernstige acute GVHD. De aanwezigheid van HLA-E*01:03 in de patiënt werd geassocieerd met een hoger risico op infecties in het algemeen en niet-CMV infecties. Onze resultaten impliceren dat HLA-E polymorfisme een rol speelt bij de ontwikkeling van posttransplantatie gerelateerd complicaties en benadrukken het belang om deze bevindingen te verifiëren in een grotere patiëntenpopulatie. 
De discussie van deze thesis bestaat uit twee delen: Uit dit proefschrift is gebleken dat HLA-DPA1 een belangrijke rol zou kunnen spelen bij de ontwikkeling van alloreactiviteit na HSCT in een 10/10 gematchte setting. Het is van belang om in een groter cohort te bestuderen of DPA1 matching naast DPB1 matching een voordelig effect heeft op de ontwikkeling van complicaties na transplantatie en of het DPA1 genotype als prognostische marker kan worden gebruikt. Aangezien we aantoonden dat polymorfisme in de alfa en beta-keten van het HLA-DP molecuul allogene $T$ cel herkenning beïnvloedt, kan worden aangedragen dat een combinatie van specifieke epitopen in de alfa- en beta-keten alloreactiviteit kan bepalen. Het specificeren van acceptabele mismatches tussen patiënt en donor zou niet alleen relevant zijn voor HLA-DP maar ook voor de andere loci die momenteel worden meegenomen in de matching procedure. Met name gezien het feit dat voor $20-40 \%$ van de patiënten geen 9-10/10 HLA gematchte donor kan worden gevonden, zou het meenemen van acceptabele mismatches het aantal potentiële donoren kunnen vergroten (hoofdstuk 9 deel I).

Met betrekking tot HLA-E, hebben we laten zien dat het HLA-G leider peptide gepresenteerd door HLA-E, de NKG2C+NK cel activatie induceert. Aangezien vorige studies hebben aangetoond dat NKG2C+ NK cellen expanderen tijdens CMV infectie en HLA-G tot expressie komt op monocyten tijdens CMV infectie, kan worden geopperd dat het HLA-E/G peptide complex een rol speelt bij het reguleren van de NKG2C+NK cel functie tijdens virale infectie. Verder benadrukken onze bevindingen het belang van HLA-E polymorfisme in transplantatie gerelateerde complicaties na stamceltransplantatie in een 10/10 gematchte setting. Gezien het feit dat wij in 81 patiënten aantoonde dat HLA-E polymorfisme van invloed is op het engraften van neutrofielen, het risico van GVHD en het risico van infecties is het nodig om deze resultaten te verifiëren in een groter cohort (hoofdstuk 9 deel II). 
Dankwoord 


\section{Dankwoord}

Zo, en dan gaat het nu toch echt gebeuren, mijn dankwoord! Al voelt mijn promotieonderzoek nog steeds niet geheel afgesloten, aangezien de officiële promotie nog moet gebeuren, kan ik toch zeggen dat ik een deur kan sluiten. En die wil ik ook niet meer open doen! Al met al waren het vijf zware, leerzame, leuke, vermoeiende en te gekke jaren en natuurlijk zijn er heel wat mensen die ik wil bedanken.

Allereerst wil ik diegene bedanken die deze periode voor mij mogelijk heeft gemaakt, namelijk mijn promoter Marcel Tilanus. Het was niet altijd even makkelijk, het waren soms pittige meetings en stevige discussies, maar het is ons gelukt! Een mooi boekje is het resultaat waar ik ontzettend trots op ben. Ook al is het uiteindelijk meer functioneel dan jij voor ogen had, maarja een aio moet nu eenmaal eigenwijs zijn toch ;-)? Ook wil ik je bedanken voor de congresbezoeken die je mogelijk hebt gemaakt, waardoor ik veel interessante mensen heb mogen ontmoeten en natuurlijke mooie landen heb kunnen bezichtigen (niet geheel onbelangrijk). Italië, Tsjechië, Griekenland, Engeland, Amerika, zijn een aantal van die landen waar ik naar toe heb kunnen gaan. Het voordeel van promoveren.

Dan ga ik door naar één van mijn co-promoteren, Christien Voorter. Vooral in het begin heb ik veel aan je gehad, jij hebt me alles over sequencen geleerd en je hebt altijd tijd voor me gemaakt als ik antwoorden op vragen had of jouw kritisch oog voor een stuk nodig had. Je gaf me altijd het gevoel dat ik makkelijk bij je binnen kon lopen, ondanks dat je het doorgaans gigantisch druk had. Voor een aio is dat ontzettend belangrijk en daar wil ik je dan ook voor bedanken.

En dan natuurlijk Lotte, mijn tweede co-promoter. Het was soms niet makkelijk om in een diagnostisch lab te beginnen waar onderzoek nog ver te zoeken was, daarom was het fijn om bij iemand terecht te kunnen die me begreep. Ik heb ontzettend veel van je geleerd, vooral door jouw manier van schrijven en leidinggeven. Ik kan met zekerheid zeggen dat jouw behulpzaamheid, openheid en de respectvolle manier waarop je mensen behandelt, jou tot een van de beste leidinggevende maakt die ik heb leren kennen. Ik ben je heel dankbaar voor alle energie die je in het HLA-E project hebt gestoken. Samen hebben we ervoor gezorgd dat het project is uitgelopen tot een mooie boom met veel vertakkingen, waar ik heel trots op ben. Daarnaast zijn we ook vrienden geworden en hebben we ontzettend veel samen gelachen. Ik zal nooit meer de pijpdrankjes in Los Angelos vergeten :;

Vanuit Lotte, moet ik direct denken aan mijn andere kamergenootje. Tja Joris, afgezien van het feit dat jij mijn plek hebt ingepikt (ja dat heb je goed gelezen) en België toen heeft gewonnen (ik snap het nog steeds niet), hebben we het toch heel goed kunnen vinden en absurd veel in een deuk gelegen. Ik heb jou leren kennen als een heel warm, charismatisch en intelligent persoon, ook al sla je soms een beetje door in je theorieën ;-), maar dat is de passie voor research die spreekt. Ondanks dat je het zelf altijd ontzettend druk had en je moest opletten dat er genoeg tijd overbleef voor je 
gezinnetje, stond je toch altijd voor me klaar als ik ergens hulp bij nodig had. Wat dat betreft kan ik zeggen dat je een inspiratie voor me was.

Niet te vergeten mijn paranimfen, Karin en Talia. Allebei hebben jullie een belangrijke rol gespeeld tijdens mijn promotie. Als jullie er niet waren dan was op verschillende momenten waarschijnlijk de bom ontploft. Karin, jij begreep me niet alleen heel goed omdat jij zelf bezig bent met promoveren maar je was ook altijd mijn steun en toeverlaat buiten het lab. Talia, ik heb jouw op het lab leren kennen en het klikte direct tussen ons. We hebben elkaar door heel wat momenten weten te trekken, maar boven alles hebben we gigantisch veel gelachen. Ik zou het niet anders hebben gedaan. Jullie zijn geweldige vriendinnen en ik ben trots dat jullie naast me zullen staan tijdens mijn verdediging. Dankjewel lieve schatten!

Al mijn collega's, nouja ex-collega's inmiddels, bij weefseltypering, heel erg bedankt voor alle leuke momenten in het lab. Niets is zo belangrijk als plezier hebben tijdens je werk. Met name Christel, Davina (inmiddels werk jij ook ergens anders), Sophie (succes met de tweede zwangerschap!), Els, Ilse, Fausto, Jacqueline, Veerle, Coline, Sandra en Mathijs, wat hebben we toch gelachen! En met een aantal van jullie een hele leuke carnaval gevierd! Ik zal jullie zeker missen. Vooral die heerlijke lach van Christel, die zelfs soms die van mij kon overstemmen ;-) Heel erg bedankt voor die gezellige momenten en goede gesprekken, ik heb veel aan je gehad.

Verder wil ik ook de secretariële medewerkers bedanken. Diana en Mieke, jullie hebben altijd voor me klaargestaan, ook al moesten veel dingen even op het laatste moment met enige spoed, ik kon altijd op jullie rekenen. Ook met betrekking tot het klaarkrijgen van mijn proefschrift hebben jullie veel voor mij betekend, heel erg bedankt!

Niet minder belangrijk wil ik ook iedereen bedanken die openstonden voor mijn vampierachtige neigingen en bloed hebben gespendeerd voor mijn onderzoek. Zonder jullie "sponsoring" had ik nooit die mooie HLA-E resultaten verkregen. Met name Jacqueline, Sandra en Ilse, jullie heb ik wel erg vaak lastig gevallen. En natuurlijk ook Coline en Annette, de bloedprikkers van de afdeling, jullie hebben al heeeeeeel wat tubes bloed moeten aftappen, dankjewel dat jullie daar altijd tijd voor vrij maakten.

Kevin, Thomas, Tammy, Mirelle, Evelien en Subash, we had some nice diners and drinks. It is very important for PhD students (although obviously Eveline is already past that) to sometimes be able to complain against your fellow sufferers and to switch off from the troubles of research. I wish all of you success, and of course have fun! And remember, everything has an end, also a $\mathrm{PhD}$ study:;

Violet, Karin, Cecile, Talia, Carmen (sinds kort schoonzusje (:)), Yvonne en Anna, mijn lieve vriendinnen. Wat is het toch ontzettend belangrijk om mensen achter je te hebben staan waarvan je het gevoel hebt dat je er altijd op terug kunt vallen. leder van jullie hebben heel veel voor me betekend, ieder op zijn eigen manier. Anna, 
unfortunately we don't see a lot of each other, but when we speak it's like you never left. I am glad you are still a good friend. Vooral Violet en Karin, in de afgelopen jaren heb ik een aantal moeilijke periodes gekend en zonder jullie onvoorwaardelijk steun zou het me nog zwaarder zijn gevallen. Dankjewel lieverds.

Kevin, iets wat begon als vriendschap is over gegaan in liefde. Jij zelf als aio begrijpt me als geen ander en weet op de juiste momenten de goede dingen te zeggen. Ik voel me een geluksvogel dat jij in mijn leven bent gestapt. Ik wil je bedanken voor de steun die je me hebt gegeven en ook vooral de portie humor $(-)$. Als jij me omarmt weet ik dat het allemaal wel goed komt...

Last but not least, mijn familie. Soms was het voor jullie moeilijk om te begrijpen hoe iemand zoveel tijd in zijn werk kan steken, maar jullie waren wel altijd geïnteresseerd in mijn bezigheden. Vooral voor jou, Tim, was het soms moeilijk te begrijpen, omdat je natuurlijk met hele andere dingen in je leven bezig was. Nu ben jij ook begonnen met een carrière en weet je hoe het is om ergens passie voor te voelen en trots op te zijn. Ik wens jou ook veel succes met je werk, al weet ik zeker dat je het fantastisch zult doen. Trudy en Jeff, ik ben ontzettend dankbaar voor alles wat jullie hebben gedaan. Wat zijn jullie toch ontzettende lieve en zorgzame mensen. Ik ben er trots op om zulke schoonouders te hebben.

Ik wil eindigen met diegene waar ik dit boekje aan wil opdragen, pap en mam. Het leven gaat niet altijd over rozen. Dat hebben jullie als geen ander moeten ervaren. Waar anderen hadden opgegeven, hebben jullie doorgezet. Ook al twijfelen jullie soms, jullie hebben het goed gedaan, zie hier het bewijs. Daar mogen jullie heel trots op zijn! Bedankt voor jullie onvoorwaardelijke liefde en steun, jullie zijn geweldige ouders.

Ik heb tranen gelachen, onnozel gedaan. En tenslotte tevreden, het licht uit gedaan. 

Curriculum vitae 


\section{Curriculum vitae}

Nina Lauterbach werd geboren op 12 januari 1985 te Heerlen. Zij behaalde haar HAVO diploma in 2002 aan College Rolduck te Kerkrade. Hierna begon ze de opleiding Maatschappelijk Werk en Dienstverlening aan Hogeschool Zuyd te Sittard. Nadat zij in 2003 haar propedeuse behaalde ging zij Gezondheidswetenschappen studeren aan de Universiteit Maastricht, waar zij in 2007 haar Bachelor diploma behaalde. Datzelfde jaar begon ze met de Master Physical Activity \& Health met specialisatie Metabolism and Nutrition aan de Universiteit Maastricht. Tijdens haar Master liep ze stage bij de afdeling Humane Biologie waar zij onder begeleiding van dr. Herman Popeijus de effecten van vetzuren op transscriptie factor PPAR-gamma bestudeerde en onder supervisie van $\mathrm{dr}$. Jonathan van Tilburg een nieuwe eiwit isolatie methode met behulp van magnetische beads onderzocht. Vervolgens liep ze haar afstudeerstage bij de afdeling Fysiologie waar ze onder begeleiding van dr. Daniel Molin de notch signaling pathway in coronaire gladde spiercellen bestudeerde. Ze studeerde af in 2008, waarna ze direct startte met haar promotieonderzoek naar de functionaliteit van HLA polymorfisme onder de supervisie van dr. Lotte Wieten, dr. Christien Voorter en prof. dr. Marcel Tilanus. In haar promotieperiode heeft zijn ook vijf maanden gewerkt bij de Unit of Molecular and Functional Immunogenetics aan het San Raffaele Scientific Institute te Milaan in Italië onder begeleiding van prof. dr. Katharina Fleischhauer. Hier deed zij onderzoek naar het effect van HLA-DP polymorfisme op de CD4+ T cel functie. De resultaten van haar promotieonderzoek staan beschreven in dit proefschrift. 

List of publications 
198 


\section{List of publications}

Lauterbach N, Voorter CEM, Rybicki L, Wieten L, Groeneweg M, Sobecks R, Kalaycio M, Tilanus MGJ, Askar M. HLA-E polymorphism is associated with risk of infection and severe acute GVHD in unrelated hematopoietic stem cell transplantation. in preparation.

Lauterbach N, Wieten L, Popeijus H, Voorter CEM, Tilanus MGJ. HLA-E regulates the NKG2C+ NK cell function through presentation of a restricted peptide repertoire. submitted.

Lauterbach N, Wieten L, Popeijus H, Vanderlocht J, Zon van PMH, Voorter CEM, Tilanus MGJ. The induction of HLA-E translation upon extracellular peptides in human PBMCs is dependent on peptide sequence and HLA-E genotype. submitted.

Lauterbach N*, Crivello P*, Wieten L, Zito L, Groeneweg M, Voorter CEM, Fleischhauer $\mathrm{K}$, Tilanus MGJ (*Equal contribution). Allorecognition of HLA-DP by CD4+ T cells is affected by polymorphism in its alpha chain. submitted.

Crivello P*, Lauterbach N*, Zito L, Sizzano F, Toffalori C, Marcon J, Curci L, Mulder A, Wieten L, Zino E, Voorter CEM, Tilanus MGJ, Fleischhauer $\mathrm{K}$ (*Equal contribution). Effects of transmembrane region variability on cell surface expression and allorecognition of HLA-DP3. Hum. Immunol. 2013: 74: 907-977.

Lauterbach N, Voorter CE, Tilanus MGJ. Molecular typing of HLA-E. Chapter 8 pp143-58 in: Methods Mol. Biol. 2012: 882:.Immunogenetics; Methods and Applications in Clinical Practice, Humana press 2012.

Lauterbach N, Voorter CE, Stallinga CM, Groeneweg M, Wieten L, Tilanus MGJ. Fulllength HLA-DPB1 diversity in multiple alleles of individuals from Caucasian, Black, or Oriental origin. Tissue Antigens 2012: 79: 165-73.

Voorter CE, Lauterbach N, Tilanus MGJ. Inactivation of a functional HLA-A gene: a 4-kb deletion turns HLA-A*24 into a pseudogene. Hum. Immunol. 2010: 71: 1197-202. 
